\title{
FIESTA RELIGIOSA
}

Y TEATRALIDAD POPULAR

\section{EN MÉXICO}

Coordinado por

BEATRIZ ARACIL Y MÓNICA RUIZ
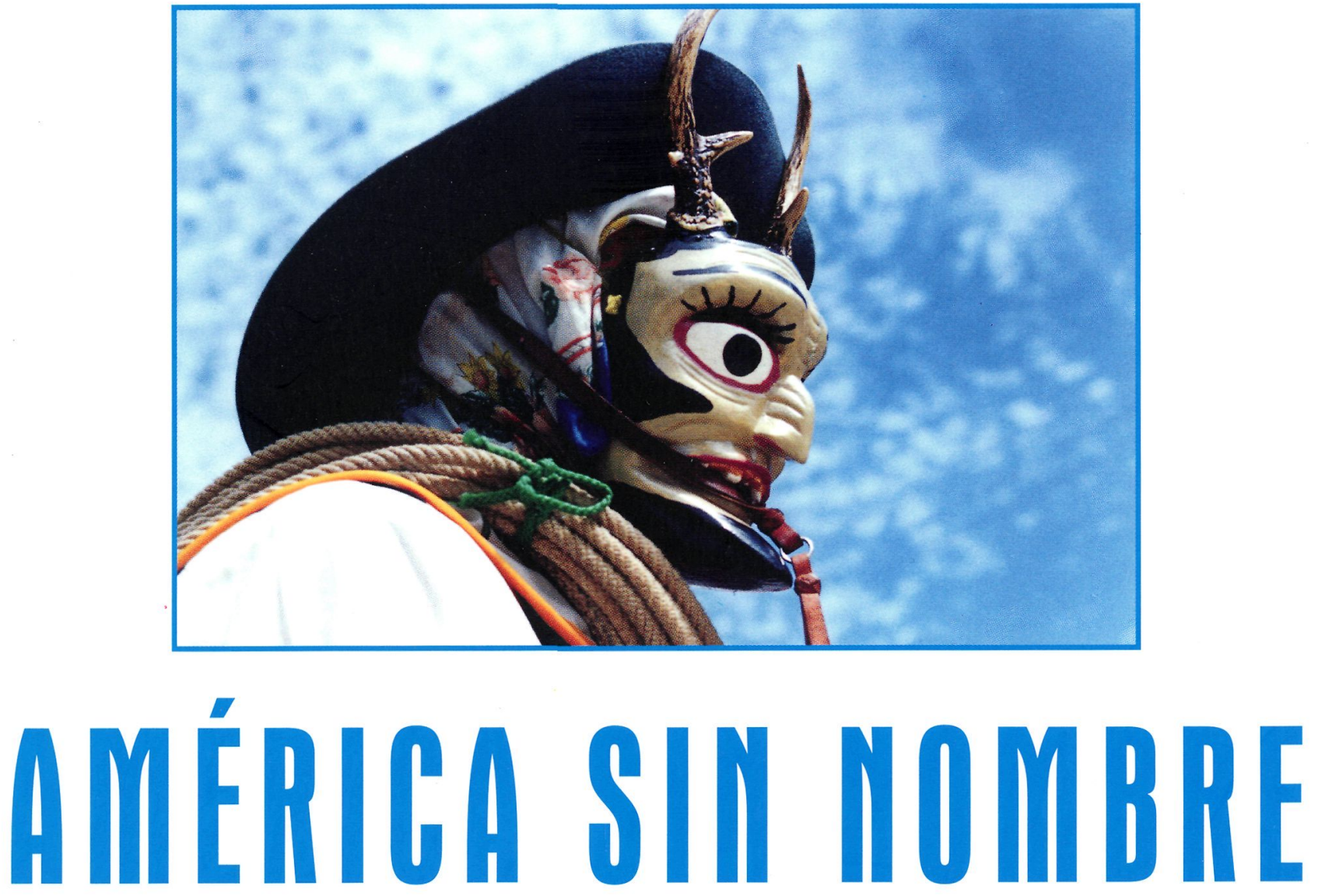

- Boletín de la Unidad de Investigación de la Universidad de Alicante: «Recuperaciones $\stackrel{\circ}{z}$ del mundo precolombino y colonial en el siglo XX hispanoamericano» 
Domingo Adame Hernández Beatriz Aracil Varón

Elizabeth Araiza Hernández Ileana Azor Blanca Cárdenas Fernández Karina Castro Santana Óscar Armando García Gutiérrez Mariza Mendoza Zaragoza Alejandro Ortiz Bullé-Goyri Armando Partida Octavio Rivera Krakowska Mónica Ruiz Bañuls 
AMÉRICA SIN NOMBRE es el Boletín de la Unidad de Investigación de la Universidad de Alicante «Recuperaciones del mundo precolombino y colonial en el siglo XX hispanoamericano» (Proyectos MCYT BFF 2002-01058, GV GRUPOS05/023 y MEC HUM2005-04177/FILO). Este número ha sido publicado por el programa de financiación de revistas del Vicerrectorado de Investigación, Desarrollo e Innovación de la UA.

Director: José Carlos Rovira

Subdirectora: Carmen Alemany Bay

Secretaria: Remedios Mataix Azuar

\section{Consejo editorial:}

Beatriz Aracil Varón (UA, coordinadora)

Miguel Ángel Auladell Pérez (UA)

Eduardo Becerra Grande (Universidad Autónoma de Madrid)

Teodosio Fernández Rodríguez (Universidad

Autónoma de Madrid)

Virginia Gil Amate (Universidad de Oviedo)

Aurelio González (El Colegio de México)

Rosa Maria Grillo (Universidad de Salerno)

Ramón Lloréns García (UA)

Francisco José López Alfonso (UV)

Sonia Mattalía (UV)

María Águeda Méndez (EI Colegio de México)

Pedro Mendiola Oñate (UA)

Francisco Javier Mora Contreras (UA)

Ramiro Muñoz Haedo (UA)

Nelson Osorio Tejeda (Universidad de Santiago de Chile)

Ángel Luis Prieto de Paula (UA)

José Rovira Collado (Universidad de Salerno)

Enrique Rubio Cremades (UA)

Francisco Tovar Blanco (Universitat de Lleida-

Estudi General)

Eva $M^{a}$ Valero Juan (UA)

Abel Villaverde Pérez (I.B. Bahía Blanca de Alicante)

Colaboradores:

Claudia Comes Peña

Mónica Ruiz Bañuls

José Ramón Albarrán

David García Vergara

Francisco Mollá Ruiz

Elena Pellús Pérez

Rafael Sellers Espasa

Paola Madrid Moctezuma

Foto portada:

Diablo. «Danza de las mascaritas» realizada por indios mixtecos en Santa Catarina Mechoacán (Oaxaca). Autora: Darina Robles.

Este boletín está asociado a la actividad del CENTRO DE ESTUDIOS IBEROAMERICANOS «MARIO BENEDETTI»

ISSN: $1577-3442$

Depósito Legal: MU-2335-1999

Composición e impresión:

COMPOBELL, S.L. Murcia
AMÉRICA SIII NOMBPRE

Boletín de la Unidad de Investigación de la Universidad de Alicante: "Recuperaciones del mundo precolombino y colonial en el siglo XX hispanoamericano»

$\mathrm{N}^{\circ} 8$, diciembre de 2006

$8 €$ 


\section{AMÉRICA SIII NOMBPE}

sumario

Beatriz Aracil

y Mónica Ruiz

Beatriz Aracil Varón

Domingo Adame Hernández

Elizabeth Araiza Hernández

Mónica Ruiz Bañuls

Óscar Armando García Gutiérrez

Mariza Mendoza Zaragoza

Ileana Azor

Armando Partida

Octavio Rivera Krakowska

Karina Castro Santana Alejandro Ortiz Bullé-Goyri

Blanca Cárdenas Fernández

\section{Editorial}

5 Reflexiones para una historia de la teatralidad religiosa popular en México

18 Teatralidad india y comunitaria en México. Un acercamiento desde la complejidad

27 La fiesta verdadera: ¿una realización feliz en el teatro? Luces y sombras de los encuentros de teatro comunitario en México

36 La devoción popular guadalupana en la teatralidad mexicana

43 Abraham e Isaac, personajes de una Epifanía en una comunidad indígena de Yucatán

51 En busca de la bienaventuranza: fiesta del Niñopan, fiesta representacional

58 Los carnavales en México. Teatralidades de la fiesta popular

68 La teatralidad actual de la Pasión en Iztapalapa

75 Notas sobre la fiesta y la representación teatral en la Semana Santa de Santa María Tonantzintla

86 El Juego de la Conquista de San Agustín Tlacotepec (Oaxaca. México)

93 Aproximaciones a Los Tecuanes, danza-drama de origen náhuatl del Estado de Guerrero

100 Ch'anantskua (Juego de la madurez) 


\title{
AMÉRICA SIII IOMBBPE
}

\section{Fiesta religiosa y teatralidad popular en México Tradición, identidad, presencia indígena}

\author{
Beatriz Aracil y Mónica Ruiz
}

A lo largo de siglos, el teatro ha sido para el ser humano una forma privilegiada de contemplarse y comprenderse a sí mismo en relación con la sociedad que le rodea. En las formas tradicionales de teatralidad popular pervive ese sentido profundo del teatro como expresión esencial de la comunidad; en México, además, esas ricas y múltiples formas de teatralidad, insertas en el marco más amplio de la fiesta (fundamentalmente de la fiesta religiosa), nos hablan sobre todo de una expresión de identidad en el ámbito indígena.

Si el teatro propiamente mexicano nace como un discurso sincrético, fruto del encuentro entre la tradición del medioevo europeo y la indígena prehispánica, en la evolución de este mestizaje, esencial para entender la identidad cultural mexicana, las comunidades indígenas han conservado, transformándolas, manifestaciones ancestrales de teatralidad pero, sobre todo, han asumido formas de la cultura y la religión cristianas, enriqueciéndolas con cosmogonías propias, una reinterpretación del pasado histórico y legendario y un intento de comprensión de los nuevos contextos sociales y políticos en los que se han visto inmersas.

A partir de un concepto amplio de «teatro» que apela, como proponen numerosos teóricos actuales, a su propia etimología (del griego $\theta \varepsilon ́ \alpha \tau \rho o v$, de $\theta \varepsilon \alpha \sigma \theta \alpha$, mirar), centrado en la interacción entre el actor y el público ante el que éste se muestra y vinculado a su vez al concepto de «teatralidad» como cualidad pre-estética de representación, el presente número de América sin nombre se centra en esas formas tradicionales de teatralidad en México que, por alejarse de los modelos cultural y socialmente dominantes del teatro profesional, son todavía excluidas, en buena medida, de los estudios teatrales o relegadas al ámbito de lo «folklórico», en muchas ocasiones incluso desde una acepción peyorativa del término.

Los trabajos que presentamos están divididos en lo que podríamos considerar tres vertientes o fases de estudio. La primera de ellas consiste en analizar desde diversas perspectivas teórico-metodológicas (historiografía teatral, ciencias religiosas, teoría teatral, antropología...) los rasgos que definen este tipo de manifestaciones teatrales, trazar algunas claves de su evolución hasta nuestros días y señalar las implicaciones sociales, ideológicas y culturales de las mismas en el marco actual de lo que podríamos definir de forma amplia (pero también algo ambigua) como «teatro popular mexicano». Ofrecemos a continuación un panorama de dichas formas de teatralidad popular a través de ejemplos significativos, pertenecientes a diferentes zonas geográficas del país y vinculados a fechas señaladas del calendario litúrgico cristiano (Navidad, Semana Santa, festividades de los santos patronos...), que se han convertido en una forma de expresión no sólo religiosa sino también identitaria de la comunidad. Por último, hemos querido dar cabida asimismo a estudios sobre las que podrían definirse como formas de pervivencia de una teatralidad prehispánica, aunque influenciada-como no podía ser de otro modo- por la religiosidad cristiana. 
La iniciativa de elaborar el presente volumen se inscribe en un marco más amplio de colaboración entre la Universidad de Alicante y la Universidad Nacional Autónoma de México que ha dado como resultado la celebración de diversos seminarios y una serie de publicaciones sobre distintos aspectos del teatro mexicano entre las que cabe destacar ahora, por su vinculación con el tema que nos ocupa, el volumen colectivo Fiesta y teatralidad de la pastorela mexicana (México, UNAM, 2004), del que en cierto modo este proyecto es una continuación.

Deseamos expresar un sincero agradecimiento a los investigadores de las universidades mexicanas que han participado en nuestro número de América sin nombre y dedicar el mismo a quien, desde ese rinconcito de México en Francia que es Perpignan (o Perpitlán), ha favorecido durante años la fructífera cooperación entre investigadores teatrales europeos y americanos: el Dr. Daniel Meyran, a quien tanto debemos los estudiosos actuales del teatro mexicano. 
Doctora en Filología Hispánica por la Universidad de Alicante (España). Especialista en teatro hispanoamericano colonial, se ha dedicado asimismo en los últimos años a la recuperación de la Crónica de Indias en la novela y el teatro latinoamericanos del siglo XX. Entre sus publicaciones cabe destacar El teatro evangelizador. Sociedad, cultura e ideología en la Nueva España del siglo XVI (Roma, Bulzoni, 1999), Abel Posse: de la crónica al mito de América (Universidad de Alicante, 2004) y la coedición del libro Fiesta y teatralidad de la pastorela mexicana (UNAM, 2004), así como numerosos artículos que forman parte de obras colectivas editadas en España, Francia y México. Actualmente es profesora de Literatura Hispanoamericana en la Universidad de Alicante y Responsable Académica del área de América Latina en la Biblioteca Virtual Miguel de Cervantes.

\section{RESUMEN}

Las actuales manifestaciones del teatro religioso popular son fruto de un proceso de evolución, adaptación y transformación de formas dramáticas que fueron surgiendo, en muchos casos, a lo largo del período colonial. El presente artículo pretende centrarse en dicho proceso y, más concretamente, en los vínculos que cabría establecer entre formas contemporáneas de teatralidad (en especial del ámbito indígena) ligadas al calendario litúrgico cristiano y las del denominado «teatro evangelizador», impulsado por los misioneros españoles desde las primeras décadas de la conquista con el fin de instruir en la nueva fe a los naturales.

A partir de una revisión crítica de conceptos como «tradición», «discurso» o «documento», se intentarán trazar claves para la comprensión de una línea evolutiva que se nos revela discontinua, llena de modificaciones, rupturas, nuevas incorporaciones o recuperaciones de modelos teatrales, debidas a muy diversas causas históricas, sociales y culturales.

\section{REFLECTIONS FOR A HISTORY OF POPULAR RELIGIOUS HISTRIONICS IN MEXICO}

\section{ABSTRACT}

The present representations of popular religious theatre have emerged from an evolutionary, adaptation and transformation process of dramatic forms which in many cases appeared during the colonial era. This article intends to concentrate on this process and, more concretely, on the possible links between contemporary dramatic forms (especially from indigenous backgrounds) linked to the Christian liturgical calendar and those from what is known as 'evangelist theatre' promoted by Spanish missionaries in the first decades following the conquest and aimed at teaching natives the new faith.

Keys to understanding an evolutionary path will be plotted via a critical revision of concepts such as 'tradition', 'discourse' or 'document', revealing a discontinuity full of changes, ruptures, new additions to or recoveries of theatre models due to extremely diverse historical, social and cultural reasons.

\section{INTRODUCCIÓN}

En el prefacio a su libro El teatro popular en Hispanoamérica. Una bibliografía anotada
(1979), René Acuña definía el «teatro popular»o «teatro folklórico» como «un conjunto de piezas dramáticas (...) por lo común anónimas, que se conservan por tradición oral o
Reflexiones para una historia de la teatralidad religiosa popular en México

BEATRIZ ARACIL VARÓN 


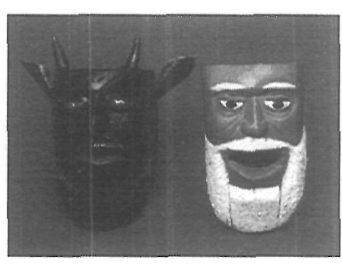

Máscaras para una danza de moros y cristianos. Morelos.

René Acuña, El reatro popular en Hispanoamérica. Una bibliografía anotada, México, UNAM 1979, pág. 9

2

Id.

3

Ibidem, pág. 10.

4

Cf., entre otros, A treasure of Mexican Folkways, New York, Crown Publishers, 1947.

5

Entre los que cabría citar Folklore de San Pedro Piedra Gorda Zacalecas (junto a Virginia R.R. de Mendoza, México, Instituío Nacional de Bellas Artes, 1952 y Folklore de la región central de Puebla (México, Centro Naciona de Investigación, Documentación e Información Musical Carlos Chávez, 1991) o sus ediciones de "La Danza de la Conquista» (Anuario de la Sociedad Folklórica de México, 1944, vol. IV, págs. 155-186); «Drama de la Pasión como se representa en Milpa Alta D.F. Manuscrito de Adalberto Fuentes Cruz') (Anuario de la Sociedad Folklórica de México, 1949, vol. Vl, págs. 249-371): Una Adoración de Pastores en Chilpancingo (México, UNAM, 1950); "Drama tradicional. Morisma de Zacatecas que se representa el 24 de junio's (Anuario de la Sociedad Folklórica de México, 1954, vol. VIII, págs. 141-162).

6

Para un recorrido por la obra de este autor puede consultarse la «Reseña bibliográfica de Fernando Horcasitas» en Fernando Horcasitas, Teatro náhuatl II, coord. por María Sten y Germán Viveros, México, UNAM, 2004, págs. 429-437.

7

Arturo Warman, La danza de moros y cristianos, México, SEPSetentas, 1972

Juan Villegas, Historia multicultural del teatro y las teatralidades

Reflexiones para una historia de la teatralidad religiosa popular en México

BEATRIZ ARACIL VARÓN

escrita, y que se suelen representar ocasional o periódicamente» ${ }^{1}$, y planteaba, entre otras cuestiones, dos problemas importantes para su estudio: en primer lugar, «su existencia marginal a los documentos históricos y civiles» $»^{2} y$, en segundo lugar, la constatación de que, a fines de los 70 , el teatro popular no había encontrado aún «la puerta por la cual ingresar al recinto universitario» ${ }^{3}$.

Aunque volveré inmediatamente a la definición propuesta por Acuña para confrontarla a otras acepciones de lo «popular» aplicadas al teatro, lo que me interesa destacar ahora es la utilización en la misma del término «tradición», que lleva a su vez al autor a partir de las «raíces peninsulares y autóctonas» de estas manifestaciones dramáticas: el tipo de teatro popular al que se refiere el investigador guatemalteco es fruto de la apropiación ( $y$, por tanto, de una sucesiva variación) de formas dramáticas a lo largo incluso de siglos, y cualquier acercamiento al mismo hace necesarios, por tanto, una búsqueda de las «raíces» y un estudio de su desarrollo.

$\mathrm{El}$ investigador que intente trazar el recorrido histórico por estas formas tradicionales de teatralidad hallará en la actualidad prácticamente los mismos problemas planteados por Acuña hace casi tres décadas: el carácter marginal de dichas manifestaciones dramáticas (que le llevará a enfrentarse con la problemática del documento) y la escasez de estudios críticos sobre las mismas, no sólo desde la perspectiva del folklore (hacia la que apuntaba Acuña) sino también, y quizá de forma más acusada, desde la historiografía teatral: por lo que respecta en concreto al ámbito mexicano, contamos con interesantes trabajos realizados por folkloristas como Frances Toor ${ }^{4}$ y Vicente T. Mendoza ${ }^{5}$ o etnógrafos como Fernando Horcasitas ${ }^{6}$, y con la existencia de algún valioso estudio de conjunto como el de Warman sobre la danza de moros y cristianos ${ }^{7}$, en el que se aúnan las perspectivas histórica y antropológica, pero en general todavía resulta difícil encontrar

en América Latina, Buenos Aires, Galerna, 2005, pág. 24.

9

Fernando Horcasitas, El teatro náhuatl, México, UNAM, 1974, pág. 163-164.

10

Esta tesis fue ya defendida, entre otros, por José Juan Arrom, este tipo de actividad teatral como objeto de los estudios historiográficos, que la excluyen precisamente por su carácter marginal. Como explicaba recientemente Juan Villegas,

El discurso crítico, no consciente de sus propios fundamentos ideológicos ni de su dependencia cultural, ha producido una historia parcial, en la cual se han privilegiado textos estéticamente europeizantes e ideológicamente convenientes a los sectores sociales en el poder. Al mismo tiempo, ha dejado fuera enormes espacios de producción de textos teatrales que han sido automáticamente discriminados y marginados ${ }^{8}$.

Ahora bien, la constatación de estas limitaciones o lagunas en la investigación teatral puede (y debe) ser también un acicate para la imprescindible incorporación de las actuales manifestaciones del teatro religioso popular a una historia del teatro (en nuestro caso, del teatro mexicano) no sólo por su importancia como producto cultural y testimonio privilegiado de los grupos sociales que las generan sino también por el hecho de constituirse como documentos que nos informan sobre la actividad teatral de épocas anteriores en la medida en que son fruto de un proceso de evolución, adaptación y transformación de formas de teatralidad que se remontan, en algunos casos, al período precolombino o al colonial.

Mi objetivo en el presente artículo es centrarme en dicho proceso evolutivo, y, más concretamente, en los vínculos que cabría establecer entre ciertas formas contemporáneas de teatralidad en el ámbito indígena y las de ese primer teatro propiamente mexicano, sincrético, que fue el impulsado por los misioneros españoles para la evangelización de los naturales desde las primeras décadas de la conquista.

He señalado ya en algún trabajo previo que, frente a la postura defendida por Fernando Horcasitas, para quien, a excepción del ciclo de la Pasión, las pastorelas y el ciclo de Santiagos, Moros y Cristianos y Pilatos, «no existe el menor vestigio del teatro misionero entre los indígenas modernos ${ }^{9}$, en mi opinión son precisamente esas «excepciones», tan destacadas en el contexto de la fiesta popular mexicana, las que permitirían hablar de cierta continuidad (entendida en cualquier caso como un complejo y discontinuo proceso) del teatro evangelizador entre la población indígena hasta la actualidad» ${ }^{10}$.

Serán por ello, sobre todo, esas formas de teatralidad (con sus rasgos peculiares de evolución) las que me servirán de base para 
algunas reflexiones sobre las características, las etapas y los parámetros de análisis de esas líneas de continuidad; reflexiones que parten necesariamente a su vez de una revisión de conceptos básicos ya citados (lo popular, lo tradicional, lo indígena, discurso marginal, documento...) que continúan siendo aprovechados y replanteados desde diversas disciplinas y perspectivas críticas.

\section{UNA CUESTIÓN DE CONCEPTOS}

En los años en que René Acuña definía el «teatro popular» a partir de la idea de tradición y como sinónimo de «teatro folklórico», el director brasileño Augusto Boal escribía diversos trabajos en los que, desde un planteamiento marxista basado en la dicotomía opresor/oprimido, advertía que, "para ser popular, el teatro debe abordar siempre los temas según la perspectiva del pueblo, vale decir, de la transformación permanente, de la desalienación, de la lucha contra la explotación, etc.» ${ }^{11}$, y establecía diversas categorías y técnicas de creación de un teatro popular entre las que citaba el aprovechamiento, con los fines citados, de las fiestas y tradiciones populares ${ }^{12}$.

La propuesta de Boal resulta representativa de una línea ampliamente difundida en la práctica y en la crítica teatral latinoamericana de las últimas décadas que Donald Frischmann ha explicado del siguiente modo:

...el término [«teatro popular»] ha llegado a significar algo más que un teatro folklórico de autor anónimo perpetuado a través de la tradición escrita u oral, tal cual lo entienden Englekirk y Acuña. Hoy día, dentro del panorama del nuevo arte popular latinoamericano, como resultado de nuevas condiciones económicas, sociales y culturales (...), el término evoca antes que nada la idea de un teatro no comercial, creado por y para las clases populares, un teatro de recursos materiales limitados, y cuyo propósito de promover los valores culturales populares generalmente se complementa con otros de tipo político y social' ${ }^{13}$.

A pesar de los problemas metodológicos que plantea una definición ideológica de lo «popular» aplicada a la actividad teatral, acrecentados por la ambigüedad del propio término «popular» ${ }^{14}$, lo cierto es que cualquier acercamiento actual al «teatro popular» deberá tener presente, como propone Frischmann, la doble vertiente del término, esto es, la existencia de «un teatro popular tradicional y folklórico de raíces indígenas y europeas y de tipo histórico y religioso» que «sigue vivo hoy día aunque en grado cada vez más mermado» y el surgimiento en América Latina, y concretamente en México, de un «nuevo teatro popular» (ampliamente estudiado por el investigador estadounidense) que «existe de, por y para las clases populares», aunque «incorpora elementos del teatro popular tradicional, reinterpretándolos de acuerdo con la situación vital del pueblo»15.

Debido a esta ambivalencia del término, resulta necesaria una delimitación del primer tipo de teatro señalado por Frischmann (que es el que nos ocupa) respecto de las nuevas formas de teatro popular que han surgido en México. Y parece claro que, aun cuestionando la validez de una definición como la de Acuña, dicha delimitación deberá incorporar como conceptos esenciales los de «tradición» $\mathrm{y}$ «folklore», o al menos asumir parcialmente la reflexión teórica que en torno a ambos conceptos (y más allá de su aplicación al teatro) se ha venido desarrollando durante décadas descle diversas disciplinas, una reflexión que será de gran ayuda a la hora de analizar tanto la realidad actual como la evolución de las formas de teatralidad vinculadas al calendario festivo.

El origen de la palabra «folklore» está vinculado a lo popular y lo tradicional: su inventor, el inglés William J. Thoms, formó el término a partir de las voces folk (pueblo) y lore (saber, conocimiento) y afirmó que «el Folklore estudiaría únicamente el saber tradicional de las clases populares» ${ }^{16}$. Ya en la década de los sesenta, e intentando superar los conflictos teóricos entre folkloristas y etnógrafos, el peruano José María Arguedas definía el folklore como «el arte del pueblo» y el Folklore como la ciencia que «estudia, de modo general, las artes tradicionales de cualquier pueblo»17. Por su parte, Efraín Morote, en los ochenta, al definir el Folklore como «un sector específico de las Ciencias Histórico-Sociales que busca determinar las leyes del surgimiento, desarrollo y extinción de las tradiciones populares", añadía que esta definición «demanda, cuando menos, una explicación nítida del criterio con que se manejan dos categorías capitales y concurrentes: Tradiciones y Populares» ${ }^{18}$. Más recientemente, Mildred Merino señalaba como dos de los elementos esenciales del hecho folklórico su carácter popular o colectivo y su cualidad tradicional o generacional (su transmisión oral de padres a hijos). Merino, en cualquier caso,
11

Augusto Boal, Técnicas latinoamericanas de teatro popular: una revolución copernicana al revés, Buenos Aires, Corregidor, 1975, pág. 28.

12

Véase ibídem, págs. 82-92

13

Donald Frischmann, El nuevo teatro popular en México, México, INBA, 1990, pág, 28.

14

Cf. Juan Villegas, Para un modelo de historia del teatro, Irvine (California), Gestos, 1997, págs. 169-172.

15

Frischmann, op. cit., pág. 42

16

José María Arguedas, "Qué es el Folklore» [1964], en Mildred Merino de Zela (comp.), Ensayos sobre folklore peruano, Lima, Universidad Ricardo Palma, 1999, pág. 39

17

Arguedas en ibidem, pág. 42. Nótese, sin embargo, la marginalidad del teatro en este tipo de trabajos, tal como denunciaba Acuña, ya que Arguedas continúa delimitando el ámbito de estudio del Folklore a «muy particularmente sus cuentos, leyendas, danzas y canciones》 (id.).

18

Efraín Morote, "Sobre el folklore» [1985], en ibidem, pág. 67 (cf. sobre ambos conceptos págs. 67-71).

Reflexiones para una historia de la teatralidad religiosa popular en México

BEATRIZ ARACIL VARON 

go» a ibidem, págs. 16-21.

\section{0}

Ramón Menéndez Pidal, Romancero hispánico (hispano-portugués, americano y sefardí), Madrid, Espasa-Calpe, 1968, tomo I, pág. XV.

\section{1}

Ibidem, p. 45.

22

Ibidem, p. 46.

23

Recordemos las propias dificultades de los folkloristas para delimitar no sólo su objeto de estudio sino sobre todo su aparato teórico-metodológico, sobre el cual advertía Morote: «no podemos por menos que reconocer que el ingente trabajo realizado hasta hoy en la esfera del FoIklore, con todo lo plausible que pueda parecernos, ha contribuido poco, casi nada, al establecimiento de Conceptuaciones Básicas relativas a la esencia de la propia disciplina" (Morote en Merino, op. cit., pág. 64).

\section{4}

Paulo de Carvalho-Neto, "Concepto y realidad del teatro folklórico latinoamericano», Folklore Americano (México), 1977, núm. 23 (junio), págs. 101-102.

\section{5}

Domingo Adame, Teatros y teatralidades en México. Siglo XX, Xalapa, Universidad Veracruzana, 2004, págs. 105-106.

\section{6}

Véase Carvalho, op. cit., págs. 102-103.

\section{7}

Véase Merino, op. cit., págs. 21-22.

\section{8}

Warman, op. cit., págs. 62-63.

Reflexiones para una historia de la teatralidad religiosa popular en México

BEATRIZ ARACIL VARÓN matizaba el sentido de estos dos elementos aclarando, en primer lugar, que, dadas las distintas acepciones del término "popular", no todo lo popular es folklórico, pero «todo lo folklórico sí es popular»y, en segundo lugar, haciendo derivar de lo tradicional a su vez otros rasgos como la plasticidad (ductilidad, asimilación que permite variaciones sin transformación de lo esencial) y el anonimato (por convertirse en creación colectiva) ${ }^{19}$.

En realidad, la utilización, por parte de $\mathrm{Me}$ rino, de los conceptos «popular» y «tradicional» no difiere demasiado de la formulada por Ramón Menéndez Pidal hace varias décadas en sus estudios sobre el Romancero español e hispanoamericano. Recordemos que Menéndez Pidal proponía entonces sustituir «el nombre tan arraigado de poesía popular (...) por el concepto y el nombre más científico de poesía tradicional» ${ }^{20}$. Su explicación, perfectamente aplicable al teatro, se basaba en el hecho de que lo tradicional implica un grado superior a lo popular en la medida en que no sólo supone «aceptación» sino también «asimilación», esto es, «la acción continuada e ininterrumpida de las variantes ${ }^{21}$. Para el erudito español,

Entre una y otra categoría hay, pues, una diferencia cuantitativa, porque la tradición supone una popularidad continua, prolongada y más extensa; pero hay también una diferencia cualitativa, pues la obra tradicional, al ser asimilada por el pueblo-nación, es reelaborada en su transmisión y adquiere por ello un estilo propio de la tradicionalidad; no es sólo anónima, sino que es impersonal22.

Asumiendo los presupuestos de Menéndez Pidal, un teatro tradicional se definiría como el que es considerado patrimonio común, con amplia difusión durante largo tiempo en la comunidad, que, debido a su asimilación por ésta, es «impersonalizado» y continuamente transformado, ajustado a los sucesivos contextos culturales. La pertinencia del término «teatro tradicional» vendría dada entonces tanto por la implicación de los rasgos señalados como por su unicidad de sentido, frente a la plurisignificación del concepto «teatro popular» (en el que, como ya se ha señalado, se aúnan la ambigüedad del propio adjetivo «popular» y su ambivalencia en el ámbito de la investigación teatral) o incluso del de «teatro folklórico", respecto al que también encontramos una diversidad de interpretaciones críticass $^{23}$; cito a este propósito sólo dos ejemplos: mientras Paulo de Carvalho-Neto definía el teatro folklórico como ...un teatro de raíces profundas en el tiempo (antigüedad) y en el individuo (inconsciencia), transmitiéndose sin enseñanzas organizadas (no-institucionalización), respondiendo a necesidades psicológicas (funcionalismo) del hombre de todas partes del globo (universalismo) ${ }^{24}$;

para Domingo Adame, en cambio, se trata de un teatro que

...toma elementos culturales populares, indígenas o mestizos, rurales o urbanos, insertándolos en un contexto cultural distinto al que surgen, dando por resultado un producto híbrido distanciado de sus fuentes, sus realizadores y sus receptores; es decir, un objeto para el consumo espectacular o la propagación de una visión de lo «autóctono»25.

Parece, pues, adecuado aceptar como concepto predominante el de «teatro tradicional», lo cual no invalida, como ya se ha apuntado, el aprovechamiento de reflexiones teóricas en torno al folklore y al teatro folklórico. En este sentido, y acudiendo a los autores ya citados, es oportuno recordar al menos dos aspectos señalados por Carvalho esenciales para comprender la evolución de este tipo de manifestaciones teatrales: su inserción en el marco más amplio de la fiesta y la «desaparición constante y progresiva de la 'palabra'» en las mismas a lo largo del tiempo ${ }^{26}$. De igual modo, resulta interesante volver a la caracterización realizada por Merino para apuntar otro rasgo básico del hecho folklórico, el de su funcionalidad: la vigencia de cualquier fenómeno folklórico (y, por tanto, también del teatro) está en estrecha vinculación con la manera en que sirve y refleja «los intereses, ideales, hábitos y costumbres» de una comunidad ${ }^{27}$. Como explica Warman respecto a la danza dramática de moros y cristianos, si una representación folklórica pervive (en el caso de las morismas "desde sus orígenes medievales hasta la actualidad»), «debe eso a su función (...), a la capacidad de satisfacer una necesidad cultural vigente $»^{28}$.

La funcionalidad del teatro tradicional es mayor en las zonas rurales: su aislamiento, su mermado desarrollo económico, su carácter conservador, suelen hacer de ellas espacios favorables a la pervivencia de costumbres ancestrales que refuerzan los rasgos identitarios de la comunidad y la participación de sus individuos. El propio Menéndez Pidal insistía en que la difusión extensa de la tradición (concretamente del canto tradicional) se debía a que había llegado «a arraigar en las clases 
rurales, las menos propensas a los cambios de la moda» ${ }^{29}$. En México, esas comunidades rurales vienen a identificarse, en general, con los grupos indígenas, lo que nos sitúa ante un nuevo concepto de difícil definición porque, como explica Warman, en la actualidad, el término indígena «no implica en ningún caso prehispánico, ni una lengua, ni un traje o una clasificación étnica» sino que

...es un nombre para reconocer un tipo de sociedad y cultura. La historia nos hace referir ese término a grupos que llevaron el mismo nombre en épocas pasadas, y a partir de que dos culturas diferenciadas se enfrentaron y se reconocieron como extraños ${ }^{30}$.

Partiendo de parámetros sociales y culturales (y no étnicos o lingüísticos), podremos considerar que es su conciencia diferencial respecto a la cultura dominante la que permite definir como «indígenas» a estos grupos que sustentan todavía, en el medio rural en el que viven (o en la traslación de éste al ámbito urbano: el barrio), tradiciones creadas por y para los indígenas del período colonial. No es sólo, pues, el carácter rural (como en otros lugares) sino también, y de manera especial, la conciencia de la diferencia, de la marginalidad, el rasgo esencial de estas culturas en las que encontramos formas tradicionales de teatralidad, tal como recuerda Ariza Acevedo en su estudio sobre la pervivencia de un teatro evangelizador colonial en Chilapa (Guerrero):

Hoy en día, todas las piezas de teatro que se encuentran en la región, son conservadas gracias a los campesinos (...). Y la razón de la subsistencia del teatro evangelizante en esta región no es otra sino el olvido y el atraso en que se encuentran en estas regiones marginadas (...). Es como si los campesinos que las conservan siguieran viviendo como hace cuatrocientos años ${ }^{31}$.

Ahora bien, esta última consideración permitiría a su vez observar el teatro religioso tradicional de las comunidades indígenas como un «discurso teatral marginal», tal como este concepto ha sido definido por Juan Villegas. En efecto, entendiendo el teatro como un tipo de discurso ${ }^{32}$, Villegas propone distinguir discursos teatrales "producidos por los sectores culturalmente hegemónicos, aunque su destinatario puede pertenecer a sectores de otros grupos culturales» ${ }^{33}$, y discursos teatrales marginales, esto es, «manifestaciones teatrales que no coinciden con los códigos estéticos e ideológicos de los emisores del discurso crítico hegemónico» ${ }^{34}$; advierte además que, por muy diversos motivos, un discurso teatral hegemónico puede acabar siendo marginal (de hecho, «la historia del teatro no es sino, precisamente, la historia de discursos desplazados desde su posición de hegemonía» ${ }^{35}$ ) o convirtiéndose en un discurso subyugado, es decir, prohibido o censurado por el sistema en el poder.

Las categorías establecidas por Villegas (discurso hegemónico, marginal, desplazado y subyugado), sin pretender ser fijas o exclusivas, dan cuenta de la pluralidad de los discursos teatrales a partir de su historicidad y de su contexto de producción, resultando especialmente útiles en su aplicación al teatro religioso tradicional mexicano, en primer lugar, porque nos recuerdan la pertinencia de recuperar este tipo de discurso marginal como parte de la historia del teatro: como explica Villegas, «historizar» significa, entre otras cosas, «investigar tanto los discursos teatrales dominantes como los marginales o subordinados, conceder importancia a los marginados y explicar las causas estéticas y sociales de su marginación» ${ }^{36}$. En segundo lugar, y en estrecha relación con lo anterior, esta categorización puede servir para explicar el proceso de evolución del teatro evangelizador colonial hacia las formas actuales de teatro tradicional como configuración de un «discurso desplazado» (de la hegemonía a la marginalidad o incluso la subyugación): si, para el propio Villegas, «el teatro de los franciscanos constituía en ese momento histórico el discurso teatral hegemónico dirigido a un sector social [y] culturalmente marginal» ${ }^{37}$, esas mismas manifestaciones teatrales, en manos ya de las comunidades indígenas, se fueron «desplazando», convirtiéndose en discursos teatrales marginales (llegando a ser prohibidas en ocasiones, al menos durante el período colonial, por mostrar una apropiación heterodoxa de la religión cristiana).

Paradójicamente, este carácter marginal, como señalaba Ariza Acevedo, debió favorecer en buena medida la pervivencia de manifestaciones teatrales, pero también ha dificultado la conservación de documentos sobre su existencia. En cualquier caso, ésta es sólo una de las vertientes de la problemática que nos plantean los documentos con los que trabajamos, una problemática que se inicia con la delimitación misma de lo que entendemos por «documento» y de los parámetros básicos que deberá tener en cuenta el investigador en el manejo del mismo.
29

Menéndez Pidal, op. cit., pág. 45.

30

Warman, op. cit., pág. 165.

31

Maclovio Ariza Acevedo, El teatro de evangelización en Chilapa, Guerrero, Chilpancingo, Universidad Autónoma de Guerrero, 1990, pág. 33.

32

Es decir, "como un acto de comunicación entre un emisor y un destinatario (receptor) en una situación específica, en el cual el emisor utiliza una pluralidad de signos (...) para construir un imaginario social y comunicar un mensaje a sus receptores》 (Villegas, Historia multicultural..., op. cit., pág. 15).

33

Ibidem, pág. 24.

34

Ibidem, pág. 25.

35

Villegas, Para un modelo..., op. cit., pág. 128.

36

Ibidem, pág. 59.

37

Ibidem, pág. 159

$\begin{gathered}\text { Reflexiones para una historia } \\ \text { de la teatralidad religiosa popular } \\ \text { en México }\end{gathered}$
BEATRIZ ARACIL VARÓN 


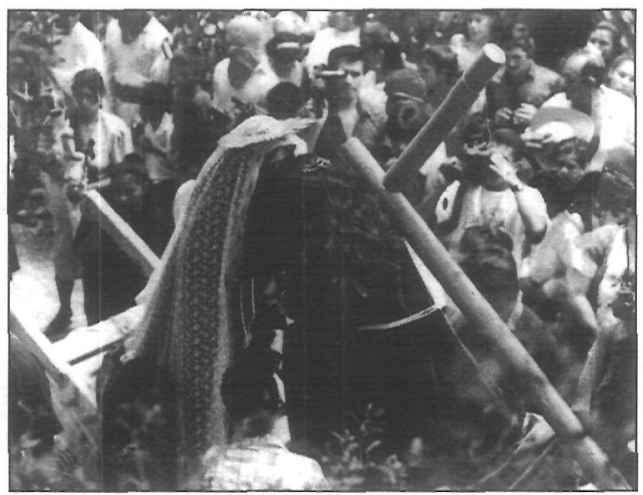

Pasión de Tzintzuntzan (Michoacán). 1995. Foto de Oscar Armando García.

38

Véase Marco De Marinis, Comprender el teatro: lineamientos de una nueva teatrología, Buenos Aires, Galerna, 1997, págs. 38-53.

39

lbidem, pág. 45.

40

Ibidem, pág. 38.

41

Villegas, Para un modelo..., op. cit., pág. 51.

\section{2}

Los fastos eran espectáculos celebrativos con los que la ciudad agasajaba a sus reyes; en ellos se llevaban a cabo torneos, justas, juegos de juglares y, como un elemento muy destacado, enfrentamientos entre moros $y$ cristianos que evocaban los episodios de la cruzada contra el Moro, en especial a través de la toma de un castillo o de batallas de galeras (cf. Joan Oleza, "Las transformaciones del fasto medieval», en Teatro y espectáculo en la Edad Media, Instituto de Cultura Juan Gil-Albert, Dipuración de Alicante y Ajuntament d’Elx, 1992, págs. 47-51).

\section{3}

Sobre las implicaciones políticoreligiosas de este tipo de representaciones en el México del XVI, véase Beatriz Aracil, El teatro evangelizador. Sociedad, cultura e ideologia en la Nueva España del siglo XVI, Roma, Bulzoni, 1999, págs. 449-519.

Reflexiones para una historia de la teatralidad religiosa popular en México

BEATRIZ ARACIL VARÓN
Para abordar este último concepto, me parece pertinente acudir a los planteamientos de Marco De Marinis $^{38}$, quien, buscando la confluencia entre la semiótica y la historiografía teatral, define el documento como un objeto de cultura construido en cuanto tal por el historiador y nos advierte sobre algunos aspectos esenciales del mismo y su tratamiento, entre los que cabría destacar los siguientes: en primer lugar, que el documento suele consignar lo excepcional (lo cual nos obligará a tener mucho cuidado de tomar como norma la excepción); en segundo lugar, que ni la presencia ni la ausencia de un documento es casual, como tampoco lo son las lagunas, los silencios de éste; $y$, en tercer lugar, que el historiador es quien rescata e interpreta el documento: éste nunca habla por sí sólo, es una pura potencialidad que adquiere su sentido en la medida en que es interpretado por el investigador; en dicha interpretación será fundamental «leer los documentos relacionándolos con otros documentos, iluminándolos y completándolos recíprocamente» ${ }^{39}$ y que esta relación, además, pueda realizarse entre documentos directos (teatrales) e indirectos (externos, pero evidenciadores de una cultura).

Siguiendo las directrices señaladas, el investigador que estudie la evolución de la teatralidad religiosa tradicional deberá indagar, por ejemplo, los motivos por los que en determinados períodos encontramos un vacío en los documentos, tomar en consideración las posibles motivaciones no religiosas de un documento inquisitorial sobre una determinada representación o buscar las razones por las que determinado cronista quiso consignar cierto hecho teatral; del mismo modo, deberá acudir de forma imprescindible a las fuentes primarias «indirectas» que nos informen sobre otras manifestaciones artísticas o sobre la religiosidad de los grupos indígenas en distintas épocas, pero también sobre la realidad política, social, cultural mexicana de cada período: dichos documentos permitirán lo que De Marinis considera un «análisis contextual de los hechos teatrales» ${ }^{40} \mathrm{o}$, como diría Villegas, «historizar» en el sentido de «establecer la contextualidad del discurso teatral. Es decir, la producción del significado dentro del contexto social y político de la época en que fue producido o representado ${ }^{41}$.
APUNTES PARA EL ESTUDIO DE LA TEATRALIDAD RELIGIOSA TRADICIONAL DESDE UNA PERSPECTIVA HISTORIOGRÁFICA

Como he indicado al inicio de estas páginas, la propuesta de trabajo que esbozo en ellas es la de trazar líneas de evolución desde las formas teatrales implantadas por los misioneros en el territorio mexicano durante el primer siglo de la colonia hasta determinadas manifestaciones de teatralidad religiosa en las actuales comunidades indígenas. Parto de la hipótesis de que es posible establecer tales líneas de evolución a pesar de que éstas se nos puedan revelar discontinuas, llenas de modificaciones, rupturas, nuevas incorporaciones o recuperaciones de modelos teatrales, y propongo precisamente una profundización en esa problemática frente a las dos posturas más comunes en torno a la posible vinculación entre el teatro evangelizador y el teatro religioso tradicional actual: el rechazo de la misma por parte de estudiosos destacados de este teatro (comenzando por el propio Horcasitas) y el hecho de haberse constituido como lugar común de trabajos sobre determinadas manifestaciones teatrales hasta el punto de convertirse en afirmación hueca, no fundamentada, en torno a los orígenes remotos de estas representaciones. Ahondar en las formas y motivaciones de este proceso evolutivo resulta absolutamente necesario para la configuración en México de esa historia del teatro plural y contextualizada que propone Villegas y a la que están contribuyendo numerosos investigadores actuales.

En la determinación de esas líneas de continuidad, podríamos distinguir tres temáticas básicas que hunden sus raíces en el teatro europeo medieval, tal como éste fue trasladado a la Nueva España por los misioneros españoles: las referentes a la Navidad y la Pasión (los dos festejos fundamentales del calendario litúrgico cristiano) y la tradición de "moros y cristianos» (en sus distintas variantes), que tiene sus orígenes en los fastos cortesanos medievales ${ }^{42}$ y que fue incorporada al contexto mexicano tanto por los conquistadores (como parte de la «cultura de conquista») como por los frailes, quienes la difundieron entre la población indígena como un eficaz medio de evangelización (al tiempo que de justificación de la conquista militar y de incorporación de los naturales al Imperio español $)^{43}$.

Mientras la pertenencia concreta al ciclo litúrgico fijó las fechas de las representaciones de Navidad (la adoración de los Reyes el día 
de la Epifanía y, sobre todo, la adoración de los pastores en Nochebuena, que derivaría hacia la actual pastorela) y de Semana Santa (con la escenificación de la Pasión de Cristo), los festejos de «moros y cristianos», tanto en España como en México y otras zonas de América, se desarrollaron en el ámbito popular como parte de la celebración de las fiestas en honor a la Virgen y los santos patronos, tanto si éstos se relacionaban de algún modo con la idea de conquista (Santiago, San Miguel...) como si no. En México además, durante el período colonial, los santos (a menudo evocadores de algún dios prehispánico) se convirtieron en "el símbolo principal que identificaba y unificaba a cada entidad sociopolítica [indígena]» ${ }^{44}$, de manera que, como explica Lockhart, «el día que se celebraba el santo patrono de la unidad era la ocasión más importante del año para toda la población (...); en dicha celebración participaban todos y en ella se mostraba la fuerza y organización interna de la entidad» ${ }^{45}$. La incorporación de las danzas de moros y cristianos a esta fiesta principal demuestra el arraigo que este tipo de representaciones adquirió en las comunidades indígenas, arraigo vinculado a su vez, entre otros aspectos, a esa demostración identitaria que era, y continúa siendo, la fiesta del santo patrono.

Aunque continúen desarrollándose en ese mismo marco festivo, es evidente que las representaciones que tienen lugar hoy día han sufrido necesariamente un proceso evolutivo (recordemos que no existe tradicionalidad sin apropiación y, por tanto, transformación) que hace difícil reconocer sus posibles raíces coloniales. $\mathrm{Y}$, sin embargo, muy a menudo dichas raíces existen a incluso explican el sentido último de algunas escenificaciones actuales. Veamos a grandes rasgos qué información aportan las fuentes conocidas hasta ahora sobre cada una de las líneas temáticas señaladas:

En el caso de las piezas sobre la Pasión, la necesaria fidelidad a unos Evangelios que describen con detalle estos hechos de la vida de Jesús hace muy complicado situar el momento de elaboración del texto dramático y su posible reelaboración en el tiempo ${ }^{46}$. Lo cierto es que, contra la opinión de aquellos investigadores para los que el sacrificio de Cristo no debió ser un tema conveniente en las primeras décadas de la evangelización (por su posible evocación de ritos prehispánicos $)^{47}$, las crónicas registran la puesta en escena habitual de este tema de conocida tradición medieval des-

de fechas muy tempranas ${ }^{48}$; por otro lado, algunos documentos inquisitoriales demuestran la amplia difusión de estas piezas en zonas como el Valle de México en una etapa bien avanzada del período colonial ${ }^{49}$; a su vez, numerosas representaciones actuales en muy diferentes estados del país atestiguan asimismo la pervivencia del tema, pero, aun en el caso de las dramatizaciones con una mayor tradición, resulta difícil remontar los textos dramáticos más allá de mediados del siglo XIX ${ }^{50}$. En definitiva, casi podríamos atrevernos a afirmar que lo que se ha mantenido

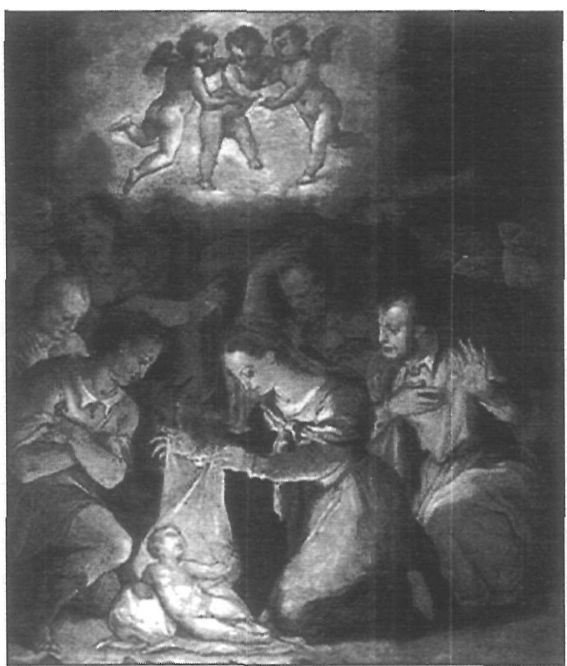

La adoración de los pastores. Giorgio Vasari. 1554 ca. Óleo sobre piedra. como tradición en México durante siglos (como en otros muchos países), más que una posible reelaboración de modelos ancestrales, ha sido la costumbre de representar las escenas de la Pasión de Cristo durante la Semana Santa siguiendo el esquema argumental de los Evangelios, que han constreñido siempre de forma necesaria los argumentos fueran o no la fuente directa de la obra

44

James Lockhart, Los nahuas después de la conquista. Historia social y cultural de la población indígena del México central, siglo XVI-XVIII, México, FCE, 1999, pág. 340.

45

Ibidem, pág. 342.

46

Sobre este problema en el ámbito español cf. Antonio Sán chez del Barrio, "Algunas noticias sobre el tiempo de Pasión Tradicional: El caso concreto de Medina del Campos, Revista de Folklore, 1987, tomo 7, núm. 83, pág. 169.

47

cf. Christian Duverger, La conversión de los indios de Nueva España, México, FCE, 1993, pág. 162 o Armando Partida, Teatro de evangelización en náhuatl, México, Consejo Nacional para la Cultura y las Artes, 1992, pág. 127.

48

Las Casas informó sobre representaciones de la Pasión que él mismo había presenciado: "Los misterios e historias de nuestra Redención es maravilla con cuánta perfección los hacen [los indios], y señaladamente les he notado muchas veces que en representar el descendimiento de la cruz y recibir el cuerpo del Salvador Nuestra Señora en su regazo, que llamamos la quinta angustia, tienen gracia especial» (Bartolomé de las Casas, Apologética historia de las Indias, Madrid, BAE, 1958, cap. 62, vol. 1, pág. 206); en la memoria del cacique don Toribio de Sandoval parece entreverse la representación anual de un neixcuitilli sobre la Pasión "Aquí comienza de cómo se hacía la pasión de Nuestro Dios; no era sólo como diversión; de cómo lo humillaron; para que nosotros recordemos cómo se hizo...; y para que recordemos cómo murió nuestro Dios, así se mandará hacer en su memoria» (cit. en Horcasitas, El teatro náhuatl, op. cit., pág. 336). Ya a fines del XVI, el franciscano fray Francisco de Gamboa organizaba representaciones de pasos de la Pasión en las que colaboraron fray Juan de Torquemada y fray Juan Bautista e incluso se consigna en la Sép tima Relación de Chimalpahin la puesta en escena de La Pasión de Nuestro Señor Jesu- cristo en el barrio mexicano de Coyoacán: «Año 4-caña. 1587 (...). Este mismo año por primera vez se hizo una representación de la pasión de Nuestro Señor Jesucristo en el Viernes Santo en Coyohuacan» (Francisco de San Antón Muñoz Chimalpahin, Relaciones originales de Chalco Amaquemecan, México, FCE, 1965, págs. 290-291).

\section{9}

Como el expediente inquisitorial sobre "las representaciones teatrales de la Pasión y muerte de Ntro. Redentor» que se ejecutaban cada año en la jurisdicción de Chalco (1768), en el que los miembros del Santo Oficio dieron su opinión sobre este tipo de representaciones e incluso se adjuntaron textos dramáticos concretos /véase «Las representaciones teatrales de la Pasión», Boletín del Archivo General de la Nación, 1934, tomo V, núm. 3, págs. 332-356; cf. Juan Leyva, ed., La Pasión de Ozumba. El teatro religioso tradicional en el siglo XVIII novohispano, México, UNAM, 2001).

50

Así, por ejemplo, la representación aciual de la Pasión de Iztapalapa, una de las más famosas de México y con más de un siglo de antigüedad, se desarrolla de acuerdo a un texto que poco tiene que ver con los consignados en el siglo XVIII, ya que está basado en la novela romántica El mártir del Gólgota de Pérez Escrich.

Reflexiones para una historia de la teatralidad religiosa popular en México

BEATRIZ ARACIL VARÓN 


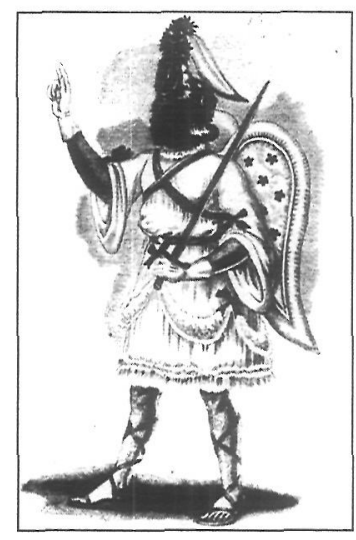

Indumentaria del ángel en la Pastorela de los siete vicios. Dibujo: Vicente T. Mendoza.

51

Pepe Rey, «Rasgos teatrales de la música de los cancioneros medievales", en Teatralidad medieval y su supervivencia, Alicante, Ajuntament d'Elx / Instituto de Cultura Juan Gil-Albert, 1998, pág. 92.

52

Véase Maximiano Trapero, La pastorada leonesa. Una pervi vencia del teatro medieval, Madrid, Sociedad Española de Musicología, 1982 (en especial págs. 106-111); opiniones contrarias al medievalismo de la pastorada las encontramos en autores como Ángel Gómez Moreno (cf. «Teatro medieval», en Carlos Alvar et al. La prosa y el teatro en la Edad Media, Madrid, Taurus, 1991, pág. 193).

53

Véase Carta de fray Pedro de Gante al rey don Felipe II. San Francisco de México, 1558, en Joaquín García lcazbalceta, Nueva Colección de documentos para la historia de México, México, Salvador Chávez Hayhoe, 1941 II, págs. 206-207.

54

Véase Carta anua jesuita de 1596, en Mariano Cuevas, His toria de la Iglesia en México, 5 vols., México, Editorial Patria, 1946, II, pág. 413.

\section{5}

La obra de Juan de Cigorondo Égloga pastoril al nacimien to del niño Jesús, escrita en

Reflexiones para una historia de la teatralidad religiosa popular en México

BEATRIZ ARACIL VARÓN en cuestión (y precisamente por ello, como ya he apuntado, enmascaran en ocasiones las influencias de muy diverso tipo que reciben las representaciones).

Por lo que respecta al ciclo navideño, y más concretamente a las famosas pastorelas, la existencia, por un lado, de testimonios sobre representaciones con este tema a lo largo del período colonial y durante el siglo XIX y, por otro, la configuración actual de una estructura dramática bastante fija y diferenciada que puede ser rastreada en etapas anteriores permitiría aventurar algunas hipótesis sobre un proceso evolutivo bastante complejo.

En esencia, el origen de la pastorela (una tradición muy arraigada no sólo en México sino también en otros países latinoamericanos), como el de las pastoradas que aún hoy se representan en España (en especial en la región castellano-leonesa), se remonta a los inicios del teatro medieval peninsular; en concreto, al ciclo del Officium pastorum. Por lo que respecta a la península, Pepe Rey ha señalado cómo las primeras manifestaciones dramáticas pastoriles desembocaron hacia el siglo XV en tres formas diferentes: la pastorada, el auto y la ensalada, siendo la pastorada «la forma más tradicional»51. El hecho de que la estructura dramática de la actual pastorada leonesa, centrada en el anuncio del ángel y las siguientes disputas entre pastores (elementos básicos a los que se añaden otros como villancicos, presentaciones, ofrecimientos al Niño, despedidas...) no difiera del esquema habitual de los autos de Navidad de los siglos XV a XVII (que amplificaron a su vez el Officium pastorum) ha llevado a autores como Maximiano Trapero a defender que las pastoradas no nacieron como forma de popularización de un texto culto sino que, por el contrario, tienen un modelo anterior común a éstos y

el siglo XVI, fue publicada por primera vez en Othón Arróniz, Teatro de evangelización en Nueva España, México, UNAM, 1979, págs. 187-238; Cayetano Javier de Cabrera y Quintero escribió en el siglo XVIII un Coloquio al nacimiento de Nuestro Señor para ser representado en el Colegio de San Miguel de Bethlem de México que ha sido publicado en Joe Romero Salinas, La pastorela mexicana: origen y evolución SEP-Cultura/FONART, México, 1984, págs. 129-141. que, por tanto, podemos asegurar el origen medieval de las pastoradas actuales, que podrían considerarse como diversas variantes, tras el discurrir de siglos, de ese modelo medieval transmitido por tradición oral ${ }^{52}$.

De ser cierta la hipótesis de Trapero, la pastorela mexicana sería también una variante de ese modelo medieval, introducido en la Nueva España fundamentalmente en dos líneas paralelas: en primer lugar, como parte de las representaciones misioneras destinadas a la población indígena, según parecen apuntar testimonios como el del franciscano fray Pedro de Gante sobre los cantos escenificados en la Navidad de $1526^{53}$ o la descripción del coloquio pastoril representado en la misión jesuita de San Felipe (Sinaloa) en 1595 conservada en las Cartas Anuas de la Compañía ${ }^{54}$; en segundo lugar, incorporado al ámbito culto, tal como atestiguan los textos conservados de distintos autores a lo largo del período colonial, desde Juan Cigorondo hasta Cayetano Javier de Cabrera y Quintero ${ }^{55}$. Ambas tradiciones debieron convivir durante el período colonial e incluso recibir fuertes influencias mutuas en el siglo XIX, cuando autores teatrales como Fernández de Lizardi, Fernández Villa o Mariano Osorno se acercaron no al género culto pastoril sino a las formas populares de las pastorelas, que por entonces ya eran «endiabladas, llenas de impropiedades violentas, arrastradas en su falta de invención» ${ }^{56}$, para proponer una peculiar revitalización (y depuración) de éstas.

Es precisamente en el siglo XIX cuando encontramos las primeras piezas teatrales fijadas textualmente en las que se muestran los elementos definidores del género actual: el diálogo jocoso de los pastores en el que se citan ya las profecías en torno al nacimiento de Cristo, la intervención del Demonio para tentarlos, la llegada del ángel (san Miguel) para enfrentarse a Luzbel y vencerlo, la anunciación y la adoración ante el pesebre con cantos y danzas. Contamos, sin embargo, con testimonios que demuestran que el paso a este tipo de estructura dramática no fue ni mucho menos lineal: si, por un lado, se ha encontrado documentación que podría remontar su origen a la segunda mitad del siglo XVIII ${ }^{57}$, por otro, hay constancia manuscrita, todavía a comienzos del siglo XX, de pastorelas que, alejadas de esa estructura popularizada en el siglo XIX, mantenían vigentes elementos destinados a reforzar la fe e instruir en la doctrina cristiana a las comunidades indí- 
genas muy similares a los que debieron emplearse en el primer siglo de la colonia ${ }^{58}$.

En cuanto a las muy diversas danzas de «moros y cristianos» que se realizan en México, sobre las que continúa siendo imprescindible el ya citado trabajo de Arturo Warman, tal vez resulte más sencillo que en las formas anteriores -al menos en algunos casos- establecer el modo en que se han ido transformando desde su introducción en el territorio, siempre y cuando se trabajen las distintas variantes en sí mismas y en relación con el resto. Pondré solamente un ejemplo: entre los textos de representaciones religiosas tradicionales que logró reunir en la región de Chilapa (Guerrero) a fines de los 80, Ariza Acevedo incluye el de una danza de Los Moros Santiagos en la que, junto a Santiago y el Rey Moro, aparecen Vespasiano y Poncio Pilatos, aspecto sobre el cual comenta este investigador:

...esta versión de los Moros Santiagos desarrolla una historia más que basada en la fantasía, basada en la ingenuidad, en lo intemporal. En ella conviven personajes de distintas épocas, por ejemplo en la escuadra mora aparece Pilatos, un personaje real y contemporáneo de Cristo, de hace veinte siglos, lidiando con Santiago, un mito de la reconquista española que debió hacer su aparición por lo menos mil años después de Pilatos. Esto nos da una idea de que la intención del anónimo juglar de esta pieza, no fue la de contar un testimonio histórico, sino el interés de propagar la fe cristiana, de una manera entretenida, sin complicaciones, ni de fechas ni de nacionalidades ${ }^{59}$.

Sin negar la evidente finalidad catequizadora de la pieza, lo cierto es que la aparente incongruencia argumental de esta danza no se debe a la ingenuidad del supuesto autor, como propone Ariza ${ }^{60}$, sino al origen colonial de la representación: como ha señalado Weckmann,

Desde un principio, en la Nueva España el apóstol Santiago encabeza siempre a los cristianos, y Poncio Pilato frecuentemente a los indios. Esta interesante circunstancia revela la antigua relación de la danza de moros y cristianos con los temas tradicionales de los cantares de gesta, especialmente los relativos a la conquista de Jerusalén o a su destrucción a manos de Tito y Vespasiano ${ }^{61}$.

En efecto, desde fechas muy tempranas del período virreinal, debió operarse una confluencia entre el tema español de la Reconquista, con la figura central del patrón Santiago, muy presente en la cultura de los vencedores (que

derivaría a su vez, entre la población autóctona, hacia formas más propiamente indígenas como las danzas de chichimecas), y el de La destrucción de Jerusalén, que tuvo una presencia destacada en la literatura y el teatro medieval europeo ${ }^{62}$ y que se debió trasladarse asimismo a la Nueva España en el primer siglo de la colonia, como demuestra la pieza en náhuatl conservada sobre este tem $a^{63}$ (cuya escritura puede ser de fines del XVII o comienzos del XVIII, pero probablemente es copia de un pieza del XVI ${ }^{64}$ ). De hecho, el manuscrito mexicano de La destrucción de Jerusalén, a pesar de no incluir al apóstol Santiago como personaje, comienza con las siguientes palabras: "Aquí se asienta la vida del Señor Santiago, de cómo sucedió que destruyó a la gran ciudad de Jerusalén, a los judíos y a Pilatos» ${ }^{65}$, palabras que, más que un «engañoso título», como plantea Horcasitas, pueden ser reflejo de esa confluencia temática que venimos comentando y que en la representación de Chilapa se da ya de forma evidente.

Aunque todavía no estemos en condiciones de explicar las fases de dicha confluencia, parece lógico pensar que guarda a su vez relación con una temprana identificación, en el contexto novohispano, entre los judíos y los moros como enemigos de la verdadera $\mathrm{fe}^{66}$,

58

En un trabajo anterior expliqué ya cómo, por ejemplo, la Pastorela de viejos (para el año de 1912), hallada en Quinceo y transcrita por Adrián F. León, fue compuesta íntegramente en lengua indígena por un autor con suficientes conocimientos de doctrina cristiana (probablemente un sacerdote $\circ$ alguien muy cercano al entorno religioso) que aprovechó la representación teatral para transmitir a los fieles determinados conceptos doctrinales (véase Beatriz Aracil, "Pastorelas tradicionales indigenas en el siglo XIX", en ibidem, págs. 23-36, en especial págs. 25-30).

\section{9}

Ariza Acevedo, op. cit., pág. 347.

\section{0}

Quien olvida además que Santiago no es sólo un mito sino también, y ante todo, un personaje histórico, uno de los apóstoles de Cristo, contemporáneo de Poncio Pilatos.
61

Luis Weckmann, La herencia medieval de México, México, El Colegio de México-FCE, 1994, pág. 518.

\section{2}

Abordado en el mismo siglo I por Josefo en su De bello ludaico, este asunto tuvo una amplia difusión en la literatura medieval europea: del siglo XIII es el poema anónimo la Des truction de Jérusalem, escrito en lemosín, sobre el cual se hizo una versión inglesa y una francesa en prosa impresa en el siglo XV al menos siete veces y traducida al español a finales de ese mismo siglo (véase María Rosa Lida de Malkiel, Jerusalén: el tema literario de su cerco y destrucción por los romanos, Buenos Aires, Universidad de Buenos Aires, 1973) Por lo que respecta en concreto al ámbito teatral, Rouanet des tacó ya la importancia, entre otras obras sobre el tema, de La vengeance de Notre-Seigneur, obra impresa siete veces entre 1491 y 1539 (Léo Rouanet, ed., Colección de autos, farsas y coloquios del siglo XVI [1901], 4 vols., Hildesheim-Nueva York, Gerg Olms Verlag, 1979, IV, pág. $211)$; en España se conserva asimismo una pieza teatral, el Auto de la destrucción de Jerusalén, recogida en el Códice de Autos Viejos libidem, I, auto XXX, págs. 502-524), que pudo componerse a finales del XVI.

\section{3}

La obra fue publicada por primera vez por Francisco del Paso y Troncoso (Destrucción de Jerusalén. Auto en lengua mexicana (anónimo) escrito en letra del siglo XVII, Florencia, Tipografía de Salvador Landi, 1907) y más tarde por Horcasitas (El teatro náhuatl, op. cit., págs. 465-495).

64

Cf. la introducción de Paso y Troncoso lop. cit., págs. 134135 y Horcasitas, El teatro náhuatl, op. cit., pág. 461.

65 Ibidem, pág. 465.

66

Recordemos que esta identificación se da desde las primeras décadas de la evangelización, tal como se muestra en la puesta en escena de una deseada Conquista de Jerusalén (Tlaxcala, 1539), en la que, según fray Toribio Motolinía, los españoles y mexicanos se enfrentarían a «Moros y Judíos con mucha munición y bastimentos" (fray Toribio de Benavente Motolinía, Historia de los indios de la Nueva España, ed. de G. Baudot, Madrid, Castalia, 1985, pág. 206).

Reflexiones para una historia de la teatralidad religiosa popular en México

BEATRIZ ARACIL VARÓN 


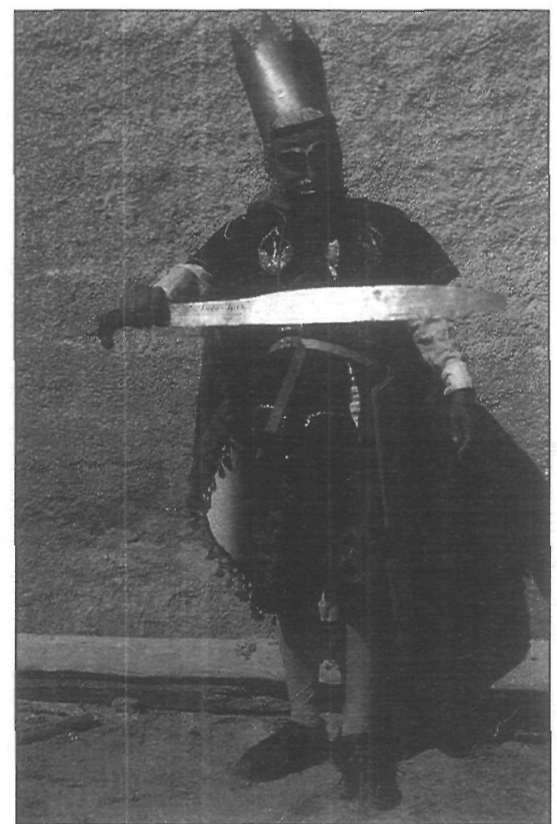

Mahoma de una danza de moros y cristianos en Oaxaca. Foto de Darina Robles.

\section{7}

Cf. a este respecto las "Tareas para una investigación futura» que propone Gisela Beutler en su artículo "Algunas observaciones sobre los textos de 'Moros y Cristianos' en México y Centroamérica», en A. David Kossoff et al. (eds.), Actas del VIII Congreso de la Asociación Internacional de Hispanistas, Madrid, Istmo, 1986, pág. 233.

\section{8}

Véase Warman, op. cit., págs. 14-16.

69

Id.

\section{0}

Annick Lempérière, «De la república corporativa a la nación moderna, México (18211869)", en Antonio Annino y François-Xavier Guerra, Inventando la nación, México, FCE, 2003, pág. 334

\section{1}

ld

72

Ibidem, pág. 330.

73

Véase ibidem, págs. 330-346.

74

Tavira, op. cit., pág. 21.

Reflexiones para una historia de la teatralidad religiosa popular en México

BEATRIZ ARACIL VARÓN así como con el hecho de que no sólo la estructura sino también el tema central de todas estas piezas sea el mismo: la conversión al cristianismo (con sus implicaciones políticas e ideológicas) desde distintas perspectivas (en Los Moros Santiagos, la conversión del gobernante, en la figura de Vespasiano, la del infiel derrotado por «España», que acepta a Cristo y recibe el bautismo, e incluso la negación de ésta, la ausencia de arrepentimiento).

Creo que el ejemplo citado sirve para demostrar cómo el cotejo de fuentes coloniales y contemporáneas es necesario para una correcta comprensión de ambas, como lo es también la utilización de los documentos externos o indirectos sobre el contexto cultural de dichas fuentes. Pero, al mismo tiempo, las preguntas que genera sobre las formas de popularización y de fusión de las variantes argumentales de una tradición muy diversa ponen de manifiesto lo lejos que estamos de una indagación sistemática y global en este sentido ${ }^{67}$; una indagación que, para cualquiera de las formas tradicionales, deberá tener en cuenta la premisa ya señalada por Warman de que la evolución social y cultural no tiende a la homogeneidad, sino «a la diversificación, al pluralismo", y que esa diversidad en México ha sido resultado sobre todo del contacto entre dos culturas, de un proceso de aculturación en el que los grupos indígenas, en su relación con la cultura dominante, han generado productos culturales influenciados por ésta, pero también voluntariamente divergentes, reafirmadores de la propia identidad 68 .

En el estudio de ese proceso evolutivo habrá que considerar además otra idea destacada por Warman: «las transformaciones básicas, las que cambian la orientación en la evolución de la culturas, no son el resultado de un proceso lento sino que por el contrario suceden en lapsos cortos y de gran intensidad» ${ }^{69}$. La tradición teatral religiosa se ha visto marcada en México, como el resto de elementos de la cultura, por momentos de transformación y ruptura como la Independencia o la Revolución. Apuntando sólo este tema (que deberá ser estudiado a fondo), parece que, al menos en el caso de la Independencia, este proceso implicó una quiebra pero también una recuperación de la tradición, y ello fue debido, por un lado, a que la indagación sobre la propia identidad surgida con los movimientos independentistas del siglo XIX llevó a una revitalización de manifestaciones propias de la tradición popular por parte de autores cultos (como hemos visto en el caso de la pastorela en manos de dramaturgos como Lizardi) y, por otro, a la propia situación de decadencia de la Iglesia católica en la segunda mitad del XIX. Como ha explicado Annick Lempérière, desde los inicios del nuevo gobierno, la religión católica, como «motivo de expresiones particularistas de identidad» vinculadas a santuarios o parroquias de santos patronos, se enfrentó a los deseos liberales de homogeneización de una identidad nacional ${ }^{70}$. Tras la Independencia, estas identidades particulares pervivieron porque

Cada ciudad, villa o pueblo conservaba su identidad propia no sólo gracias a su gobierno sino también mediante el culto a sus santos patronos y demás devociones particulares que llevaban a cabo cofradías y conventos, ayudados por el ayuntamiento ${ }^{71}$.

De hecho, esta situación fue apoyada en un principio por el poder: las constituciones mexicanas hasta 1847 incluyeron la religión católica como única del Estado y el calendario oficial mantuvo las «fiestas religiosas nacionales» (Semana Santa, Corpus Christi, Virgen de Guadalupe) junto a las nuevas fiestas «cívicas» ${ }^{72}$. Hubo que esperar a las Leyes de Reforma, y especialmente a la Ley Lerdo de 1856, con la desamortización de los bienes corporativos, y en concreto los eclesiásticos, para ver el triunfo de una república liberal que impuso una nueva forma de sociedad dominada definitivamente por el poder civil y no por el religioso ${ }^{73}$. Frente a un progreso urbano marcado por la festividad cívica, las comunidades rurales mantuvieron desde entonces sus fiestas religiosas como señas de identidad de una cultura marginal, sufriendo además un importante cambio al quedar libres de la autoridad del clero. El resultado fue una continuidad de las manifestaciones tradicionales respecto al período anterior, ya que, como explica Luis de Tavira, los laicos piadosos que se hicieron cargo de las ceremonias religiosas volvieron «a las tradiciones paralitúrgicas del pasado colonial» ${ }^{74}$, pero también una mayor libertad de las formas y, sobre todo, de los contenidos, que ya no debían ajustarse a la ortodoxia de la estructura eclesiástica (circunstancia muy reveladora para el estu- 
dio de algunas representaciones de la época, en especial de moros y cristianos, como ha demostrado Warman ${ }^{75}$ ).

$\mathrm{Al}$ estudio de estos contextos socio-políticos tan significativos habrá que añadir necesariamente el de los contextos propiamente culturales. En este sentido, se hace necesario profundizar en algunos aspectos poco trabajados como el de las influencias en el teatro religioso tradicional de otros géneros, tanto cultos como populares: así, por ejemplo, resulta imposible comprender el desarrollo de las representaciones de la Pasión a partir del último tercio del siglo XIX sin atender al éxito de la novela El Mártir del Gólgota (18631864), del escritor español Enrique Pérez Escrich ${ }^{76}$, o trazar la evolución de las danzas de moros y cristianos desde sus orígenes sin analizar sus conexiones con el Romancero. $Y$ es precisamente el vínculo con esa manifestación folklórica tan difundida en Hispanoamérica, destacado ya por investigadores como Beutler ${ }^{77}$, el que me lleva a plantear una última reflexión metodológica. Aludo para ello a un trabajo reciente de Milena Cáceres publicado en Lima, La fiesta de moros y cristianos en el Perú, en el que se estudia la Relación de la bistoria del Ave María del Rosario o Garcilazo que todavía se representa periódicamente en Huamantanga (departamento de Lima). El trabajo de Cáceres analiza esta danza de moros y cristianos cotejando su texto con distintas fuentes españolas de los siglos XVI y XVII sobre este episodio de la conquista de Granada, entre ellas, el romance «Cercado está Santa Fe», que para la autora constituye «el armazón sobre el que reposa» la pieza peruana $^{78}$. El libro puede servir de modelo para observar las posibilidades de estudios comparativos concretos en la dilucidación de estas vinculaciones entre la tradición teatral y la romancística, pero si lo cito además a este propósito es porque la autora maneja, en su análisis de la obra en cuestión, conceptos propuestos por Menéndez Pidal y Diego Catalán para el estudio del Romancero (concretamente los de «versión» y «motivo» ${ }^{79}$ ), esto es, traslada a la investigación teatral una metodología que ha resultado válida en el ámbito de la poesía tradicional.

A pesar de las evidentes diferencias entre ambos géneros, seguir los pasos de los estudios realizados durante más de un siglo sobre el Romancero en España y América puede abrir un vasto campo en las investigaciones sobre el teatro religioso tradicional. En primer lugar, porque, como hemos visto desde

el epígrafe anterior (y corrobora el trabajo de Cáceres), algunos conceptos planteados por los estudiosos del Romancero han resultado de gran funcionalidad para el estudio de ambas manifestaciones culturales tradicionales; en segundo lugar, porque los trabajos de conjunto realizados en este ámbito (entre los que destaca el de Mercedes Díaz Roig sobre el Romancero tradicional de América ${ }^{80}$ ) pueden servir de modelo para un necesario estudio comparativo con otras zonas geográficas del continente en las tres líneas temáticas propuestas (representaciones de la Pasión, pastorelas y danzas de moros y cristianos); en tercer lugar, porque los investigadores de la poesía tradicional han incorporado ya el teatro a sus perspectivas de análisis (como demuestran los títulos sobre este género que se incluyen en la Bibliografía descriptiva de la poesía tradicional y popular de México coordinada por Aurelio González $\left.{ }^{81}\right)$; y, por último, porque los estudios romancísticos cuentan incluso con algún proyecto de aplicación de las nuevas tecnologías (como el Proyecto del Romancero Pan-bispánico incorporado a la WEB por Suzanne Petersen ${ }^{82}$ ) que puede favorecer la sistematicidad a la hora de enfrentarnos a un objeto de estudio caracterizado precisamente por la multiplicidad de variantes.

La utilización de bases de datos informáticas, el manejo no sólo de las variantes teatrales sino también de la bibliografía crítica que sobre ellas se ha desarrollado en el resto de América Latina o los estudios comparativos entre géneros tradicionales pueden, junto al resto de los aspectos señalados a lo largo del presente epígrafe, ser base para futuras líneas de trabajo en el estudio histórico de las formas tradicionales de teatralidad religiosa en México. Advertía Menéndez Pidal en la nota preliminar a su Romancero hispánico:

\section{Es verdad que el romancero de tan dilatada vida apa- rece dividido en dos porciones muy separadas: una antigua, perteneciente a los siglos XV y XVI, y otra moderna, correspondiente a los siglos XIX y XX. A primera vista parecerá incongruente establecer una relación efectiva entre ambas porciones (...). Y, sin}

\section{5}

Véase Warman, op. cit., pág. 133. Las reflexiones de Warman podrían servir asimismo para comprender los heterodoxos finales de algunas danzas de moros y cristianos contemporáneas como la de Los Moros Chinos de Chilapa, que no incluye la conversión, pero sí el lamento de los moros derrotados por Santiago Icf. ed. de Ariza Acevedo, op. cit., póg. 419).
76

Base de La Pasión de lztapalapa, pero también de otras muchas representaciones actuales como las Judeas nicaragüenses (véase el trabajo de Roberto Sánchez Ramírez para el diario La Prensa, 21-3-2005, en http:// www-ni.laprensa, com.ni/archi vo/2005/marzo/21/nacionales/nacionales-20050321. 01.html).

\section{7}

Véase Gisela Beutler, La historia de Fernando y Alamar Contribución al estudio de las danzas de moros y cristianos en Puebla (México), Stuttgart, Franz Steiner Verlag Wiesbaden, 1984.

\section{8}

Milena Cáceres Valderrama, La fiesta de moros y cristianos, Lima, Pontificia Universidad Católica del Perú, 2005.

\section{9}

Conceptos que son consecuen cia, a su vez, del de tradicionalidad ya planteado (véase ibidem págs. 53-65).

\section{0}

Mercedes Díaz Roig, Romancero tradicional de América, México, El Colegio de México, 1990.

81

Aurelio González (coord.), Bibliografia descriptiva de la poesía tradicional y popular de México, México, El Colegio de México, 1993

\section{2}

Como explica la propia Petersen en su página (http://depts. washington.edu/hisprom/es panol/l, este proyecto a largo plazo pretende poner en línea "a) una bibliografía critica del género, b) una muestra representativa de todos los romances documentados por el mundo desde el siglo $\mathrm{XV}, \mathrm{cl}$ representación cartográfica de datos romancísticos primarios y secundarios y dl reproducciones musicales de recitaciones originales y su notación musical»; cf. Suzanne Petersen, «El encuentro del Romancero en América con el proyecto romancístico en la WEB: asignatura pendiente», Anales de Literatura Hispanoamericana, 2001, núm. 30, págs. 135155.
Reflexiones para una historia de la teatralidad religiosa popular en México

BEATRIZ ARACIL VARÓN 
83

Menéndez Pidal, op. cit., págs. XIII-XIV.
Reflexiones para una historia de la teatralidad religiosa popular en México

BEATRIZ ARACIL VARÓN embargo, cuando examinemos el modo como ha ido descubriéndose el romancero actual, nos convenceremos de que él existió durante varios siglos antes, aunque ignorado o negado, y cuando penetremos el carácter y el valor de la producción antigua y de la moderna en su conjunto, veremos que no hay abismo ninguno ni solución de continuidad entre los romances de antes y los de dos siglos después ${ }^{83}$.

Sin duda un estudio sistemático, global y contextualizado, al que están contribuyendo ya los investigadores actuales, permitirá a la historiografía teatral en México (y en otras zonas de América) establecer no sólo, de manera semejante a la propuesta por $\mathrm{Me}-$ néndez Pidal respecto a la poesía tradicional española e hispanoamericana, una "relación efectiva» entre el teatro evangelizador del siglo XVI y determinadas formas de teatralidad actuales sino también las claves de continuidad, ruptura, renovación y apropiación en el proceso evolutivo de las que son todavía hoy valiosas manifestaciones de la cultura mexicana.

\section{BIBLIOGRAFÍA}

Acuña, René, El teatro popular en Hispanoamérica. Una bibliografía anotada, México, UNAM, 1979.

Adame, Domingo, Teatros y teatralidades en México. Siglo $X X$, Xalapa, Universidad Veracruzana, 2004.

Alvar, Carlos et al., La prosa y el teatro en la Edad Media, Madrid, Taurus, 1991.

Annino, Antonio y François-Xavier Guerra (coords.), Inventando la nación, México, FCE.

Aracil, Beatriz, El teatro evangelizador. Sociedad, cultura e ideología en la Nueva España del siglo XVI, Roma, Bulzoni, 1999.

- ; García, Óscar Armando; Ortiz, Alejandro; Raffi-Béraud, Catherine y Román Calvo, Norma (coords.), Fiesta y teatralidad de la pastorela mexicana, México, UNAM, 2004.

Ariza Acevedo, Maclovio, El teatro de evangelización en Chilapa, Guerrero, Chilpancingo, Universidad Autónoma de Guerrero, 1990.

Arrom, José Juan, El teatro de Hispanoamérica en la época colonial, La Habana, Anuario Bibliográfico Cubano, 1956.

Arróniz, Othón, Teatro de evangelización en Nueva España, México, UNAM, 1979.

Benavente Motolinía, fray Toribio de, Historia de los indios de la Nueva España, ed. de G. Baudot, Madrid, Castalia, 1985.
Beutler, Gisela, La bistoria de Fernando y Alamar. Contribución al estudio de las danzas de moros y cristianos en Puebla (México), Stuttgart, Franz Steiner Verlag Wiesbaden, 1984.

- , «Algunas observaciones sobre los textos de 'Moros y Cristianos' en México y Centroamérica», en A. David Kossoff et al. (eds.), Actas del VIII Congreso de la Asociación Internacional de Hispanistas, Madrid, Istmo, 1986, págs. 221-233.

Boal, Augusto, Técnicas latinoamericanas de teatro popular: una revolución copernicana al revés, Buenos Aires, Corregidor, 1975.

Cáceres Valderrama, Milena, La fiesta de moros y cristianos, Lima, Pontificia Universidad Católica del Perú, 2005.

Carvalho-Neto, Paulo de, «Concepto y realidad del teatro folklórico latinoamericano», Folklore Americano (México), 1977, núm. 23 (junio), págs. 101-115.

Casas, Bartolomé de las, Apologética historia de las Indias, Madrid, BAE, 1958.

Chimalpahin Cuauhtlehuanitzin, Francisco de San Antón Muñoz, Relaciones originales de Chalco Amaquemecan, México, FCE, 1965.

Cuevas, Mariano, Historia de la Iglesia en México, 5 vols., México, Editorial Patria, 1946.

De Marinis, Marco, Comprender el teatro: lineamientos de una nueva teatrología, Buenos Aires, Galerna, 1997.

Destrucción de Jerusalén. Auto en lengua mexicana (anónimo) escrito en letra del siglo XVII, ed. de Francisco del Paso y Troncoso, Florencia, Tipografía de Salvador Landi, 1907.

Díaz Roig, Mercedes, Romancero tradicional de América, México, El Colegio de México, 1990.

Duverger, Christian, La conversión de los indios de Nueva España, México, FCE, 1993.

Frischmann, Donald, El nuevo teatro popular en México, México, INBA, 1990.

García Icazbalceta, Joaquín, Nueva Colección de documentos para la historia de México, 2 vols., México, Salvador Chávez Hayhoe, 1941.

González, Aurelio (coord.), Bibliografía descriptiva de la poesía tradicional y popular de México, México, El Colegio de México, 1993.

Horcasitas, Fernando, El teatro nábuatl, México, UNAM, 1974. 
- , Teatro nábuatl II, coord. por María Sten y Germán Viveros, México, UNAM, 2004.

Leyva, Juan (ed.), La Pasión de Ozumba. El teatro religioso tradicional en el siglo XVIII novohispano, México, UNAM, 2001.

Lida de Malkiel, María Rosa, Jerusalén: el tema literario de su cerco y destrucción por los romanos, Buenos Aires, Universidad de Buenos Aires, 1973.

Lockhart, James, Los nabuas después de la conquista. Historia social y cultural de la población indígena del México central, siglo XVI-XVIII, México, FCE, 1999.

Mendoza, Vicente T., "La Danza de la Conquista», Anuario de la Sociedad Folklórica de México, 1944, vol. IV, págs. 155-186.

- , "Drama de la Pasión como se representa en Milpa Alta D.F. Manuscrito de Adalberto Fuentes Cruz», Anuario de la Sociedad Folklórica de México, 1949, vol. VI, págs. 249-371.

- Una Adoración de Pastores en Chilpancingo, México, UNAM, 1950.

- y Virginia R.R. de Mendoza, Folklore de San Pedro Piedra Gorda, Zacatecas, México, Instituto Nacional de Bellas Artes, 1952.

- , «rama tradicional. Morisma de Zacatecas que se representa el 24 de junio», Anuario de la Sociedad Folklórica de México, 1954, vol. VIII, págs. 141-162.

- Folklore de la región central de Puebla, México, Centro Nacional de Investigación, Documentación e Información $\mathrm{Mu}$ sical Carlos Chávez, 1991.

Menéndez Pidal, Ramón, Romancero bispánico (hispano-portugués, americano y sefardi), tomo I, Madrid, Espasa-Calpe, 1968.

Merino de Zela, Mildred (comp.), Ensayos sobre folklore peruano, Lima, Universidad Ricardo Palma, 1999.

Oleza, Joan, «Las transformaciones del fasto medieval», en Teatro y espectáculo en la Edad Media, Instituto de Cultura Juan Gil-Albert, Diputación de Alicante y Ajuntament d'Elx, 1992, págs. 47-51.

Partida, Armando, Teatro de evangelización en nábuatl, México, Consejo Nacional para la Cultura y las Artes, 1992.
Petersen, Suzanne, «El encuentro del Romancero en América con el proyecto romancístico en la WEB: asignatura pendiente», Anales de Literatura Hispanoamericana, 2001, núm. 30, págs. 135-155.

«Las representaciones teatrales de la Pasión», Boletín del Archivo General de la Nación, 1934, tomo V, núm. 3, págs. 332-356.

Rey, Pepe, «Rasgos teatrales de la música de los cancioneros medievales», en Teatralidad medieval y su supervivencia (Actas del Seminario celebrado con motivo del III Festival d'Elx de Teatre i Música Medieval), Alicante, Ajuntament d'Elx / Instituto de Cultura Juan Gil-Albert, 1998, págs. 89-95.

Romero Salinas, Joel, La pastorela mexicana: origen y evolución, SEP-Cultura/FONART, México, 1984.

Rouanet, Léo (ed.), Colección de autos, farsas y coloquios del siglo XVI [1901], 4 vols., Hildesheim-Nueva York, Gerg Olms Verlag, 1979, IV.

Sánchez del Barrio, Antonio, "Algunas noticias sobre el tiempo de Pasión Tradicional: El caso concreto de Medina del Campo", Revista de Folklore, 1987, tomo 7, núm. 83, págs. 169-175.

Tavira, Luis de (ed.), Autos, pastorelas y dramas religiosos. 1817-1862, México, Consejo Nacional para la Cultura y las Artes, 1995.

Toor, Frances, A treasure of Mexican Folkways, New York, Crown Publishers, 1947.

Trapero, Maximiano, La pastorada leonesa. Una pervivencia del teatro medieval, $\mathrm{Ma}$ drid, Sociedad Española de Musicología, 1982.

Villegas, Juan, Para un modelo de bistoria del teatro, Irvine (California), Gestos, 1997.

-, Historia multicultural del teatro y las teatralidades en América Latina, Buenos Aires, Galerna, 2005.

Warman, Arturo, La danza de moros y cristianos, México, SEP-Setentas, 1972.

Weckmann, Luis, La herencia medieval de México, México, El Colegio de MéxicoFCE, 1994. en México 

cializado en Teatro. Ha sido profesor en la Universidad Nacional Autónoma de México y en varias universidades mexicanas, fue director del Centro Nacional de Investigación Teatral del Instituto Nacional de Bellas Artes, actualmente es director de la Facultad de Teatro de la Universidad Veracruzana. Es autor de los libros El director teatral intérprete-creador. Teatros y Teatralidades en México. Siglo XX y Elogio del Oximoron. Introducción a las teorias de la teatralidad. Es miembro del Sistema Nacional de Investigadores de México.

\title{
TEATRALIDAD INDIA Y COMUNITARIA EN MÉXICO. UN ACERCAMIENTO DESDE LA COMPLEJIDAD
}

\author{
DOMINGO ADAME HERNÁNDEZ
}

\section{RESUMEN}

La teoría y la práctica del teatro indio y comunitario contemporáneo de México se ha debatido entre la preservación y la transformación de los elementos culturales propios de los pueblos en los que esta actividad se realiza.

La orientación ha estado en función del origen del realizador/investigador y los resultados han sido generalmente parciales. Es por ello que, desde mi experiencia como creador/investigador de este teatro, propongo una estrategia dialógica basada en el Pensamiento Complejo que incluya y problematice todos los elementos culturales que esta teatralidad pone en juego.

\section{INDIAN AND COMMUNITY HISTRIONICS IN MEXICO: AN APPROACH FROM COMPLEXITY}

\section{ABSTRACT}

The theory and practice of contemporary Indian and community theatre in Mexico has struggled with the preservation and transformation of traditional village cultural elements where the performance is beld.

The origins of the producer/researcher bave dictated the orientation chosen with results generally turning out to be biased. It is for this reason that, in my experience as producer/researcher of this type of theatre, a dialogic strategy based on Complex Thought which includes and problematises all cultural elements this drama brings into play is proposed.

\section{INTRODUCCIÓN}

El conflicto que se ha vivido y aún persiste en México en el ámbito cultural y, específicamente en el teatral, es el enfrentamiento de concepciones muy diferentes entre el pensamiento indígena y el pensamiento occidental. El mito y la magia opuestos a la historia y a la ciencia. En el mismo sentido, la teoría y la práctica del teatro indio y comunitario con- temporáneo se debaten entre la preservación y la transformación de los elementos culturales propios de los pueblos en los que esta actividad se realiza. La alternativa, a partir de mi experiencia como creador/investigador del teatro indio y comunitario, no es la aniquilación de uno u otro componente; propongo, en cambio, una estrategia dialógica basada en el Pensamiento Complejo que incluya y cuestione todos los elementos culturales que esta 
teatralidad pone en juego, a saber: su sentido, formas de producción, intención, técnicas y conocimientos.

Considero que el teatro se debe estudiar como movimiento cultural vivo, porque verlo solamente como disciplina artística es seguir manteniendo el concepto reduccionista occidental, pues el teatro, y sobre todo la teatralidad, están presente en distintas actividades que el ser humano realiza en comunidad y, a su vez, éstas se relacionan con otras manifestaciones en la vida del individuo y de la sociedad. Por eso creo necesario identificar en cualquier investigación de carácter cultural los niveles deterministas del imprinting cognitivo y su normalización, así como sus posibilidades de debilitamiento.

Los individuos conocemos, pensamos y actuamos de conformidad con paradigmas culturalmente grabados que definen nuestras visiones del mundo, los mitos y las ideas, las actividades y las conductas. Además, un gran paradigma está profundamente inscrito en la organización de una sociedad a la cual determina, tanto como ella lo hace con él. La doctrina, sabemos, es dogmática por naturaleza, se erige como poseedora de la verdad, a diferencia de la teoría que está abierta a la crítica. Bajo el «conformismo cognitivo», nos aclara Edgar Morin, hay mucho más que eso, hay un «imprinting cultural» que marca irreversiblemente el espíritu individual en su modo de conocer y actuar ${ }^{1}$. La normalización, al controlar cualquier desviación de forma represiva o intimidatoria, se convierte en custodia del imprinting. Éste y la normalización operan recursivamente, así los modos de conocimiento de los individuos son elaborados por una cultura que produce dichos modos 2 . Precisamente por eso se pueden reconocer cambios, de tal manera que es necesario considerar, por una parte, los constreñimientos sociales, culturales e históricos que inmovilizan y aprisionan al conocimiento y, por otra, las condiciones sociales, culturales e históricas que lo movilizan o liberan posibilitando su innovación y evolución.

Para debilitar o atenuar el imprinting y la normalización, Morin visualiza tres caminos: a) una vida cultural e intelectual dialógica que admita pluralidad/diversidad de puntos de vista, intercambios múltiples de información, conflicto entre concepciones y visiones del mundo, así como la existencia de una ley del diálogo y un comportamiento individual dialógico; b) con el «calor cultural» que estimule los intercambios, enfrentamientos, y polémicas entre opiniones, ideas y concepciones; y c) con la existencia de desviantes potenciales, para lo cual, dice, se requiere un rico pluralismo cultural y cierta autonomía del

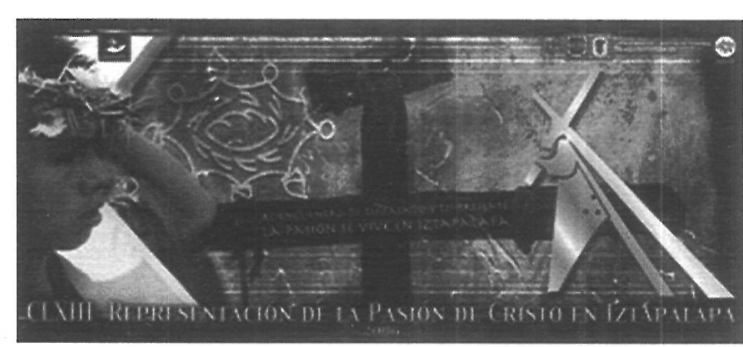

Cartel anunciador de la Pasión de Cristo. Izłapalapa 2006. estatus de los artistas, autores y pensadores.

Aplicando este aparato conceptual a nuestro tema de estudio, observamos que el discurso del teatro indio y comunitario en México ha estado marcado por el imprinting y la normalización de la Conquista, pero también ha sido confrontado por quienes buscan preservar los principios del pensamiento mesoamericano.

\section{FORMAS TRADICIONALES Y CON- TEMPORÁNEAS DE TEATRO INDIO Y COMUNITARIO}

El teatro indio y comunitario tradicional corresponde a aquel que, con un sentido de preservación cultural, practican grupos étnicos y campesinos marginados, oprimidos y dominados, localizados en rancherías, poblaciones rurales, barrios y colonias urbanas o sectores subalternos. Entre sus formas se incluyen: ceremonias, danzas-drama, danzas, comedias, farsas, sainetes, loas, églogas, autos, entremeses, pastorelas, etcétera.

Dentro de sus características están las siguientes: 1) Poseen un contenido y esencia de identidad, 2) tienen como función principal la legitimación de la cohesión grupal y 3) conservan series de complejos socioculturales, estructurados en especie de "esquemas" o «sistemas» que tienen estrecha relación tanto con la memoria histórica como con la cosmogonía y la cosmovisión; cuyas partes esenciales permanecen ocultas en la memoria colectiva y sólo reaparecen cíclicamente en las representaciones colectivas de tipo mágicoreligioso $y$, siempre, en actitud solemne ${ }^{3}$.

Como resulta evidente, el motivo religioso es predominante, efectuándose ceremonias acordes al calendario de la iglesia católica en poblaciones indígenas y mestizas, rurales y urbanas. La conmemoración de la «Semana Mayor» constituye el principal acontecimiento dentro de la iglesia católica. Las representaciones de la Pasión de Cristo tienen un carácter ritual que abarcan a la población en su totalidad con sus componentes humanos
1

Edgar Morin, «El pensamiento subyacente» en El Método IV, Las ideas, Madrid, Cátedra, 1992, pág. 29.

2

Ibidem, pág. 30

3

Manuel Jiménez Castillo, "Inves tigación sobre teatro indígena y campesino. Un punto de vista III Encuentro Nacional de Investigación Teatral, México, CITRUINBA, 1992, págs. 44-45. antropológico», en Memoria del
Teatralidad india y comunitaria en México. Un acercamiento desde la complejidad DOMINGO ADAME HERNÁNDEZ 


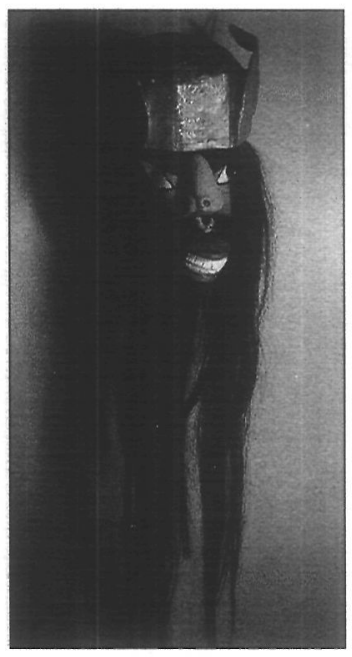

Máscara de un danzante yaqui.

\section{4}

Gabriel Weisz, «La piel mágica de los dioses», Memoria del Encuentro de Teatro Rural, México, Dirección General de Culturas Populares/SEP, 1985 [copia mimeográfica, sin paginación].

5

Frances Toor, A treasury of Mexican Folklore, New York, Crown, 1947, págs. 225-229.

Francisco Acosta Báez, "Teatro comunidad», La escena latinoamericana, nueva época, 5/6, págs. 52-57.

Donald Frischmann, «Etnicidad activa: nativismo, otredad y reatro indio en México», Memoria del III Encuentro Nacional de Investigación Teatral, México, $\mathrm{Cl}$ TRU-INBA, 1992, págs. 25-34.

Donald Frischmann, «El teairo en las comunidades zapatistas de Chiapas», Investigación teatral, núm. 3, págs. 13-21

Teatralidad india y comunitaria en México. Un acercamiento desde la complejidad

DOMINGO

ADAME HERNÁNDEZ y físicos. En las poblaciones indígenas se da una yuxtaposición entre el simbolismo propio y el occidental, predominando el primero en el uso del espacio, danzas, batallas, música, máscaras, vestuario, lenguaje y objetos que forman parte de la ceremonia.

Entre las culturas indias destacan las celebraciones que efectúan los Yaquis y Mayos de Sonora y Sinaloa, así como los Coras de $\mathrm{Na}$ yarit y Jalisco. Ambas son expresiones de un teatro total que engloba lo social, lo natural y lo sobrenatural.

La pastorela nació en nuestra tradición cultural decembrina como una forma de diseminación de la doctrina cristiana que, rápidamente, se convirtió en una auténtica manifestación de teatro popular.

El Teatro maya tradicional tiene diversas manifestaciones; entre otras se encuentra el Okosta Pol o "Baile de la Cabeza del Cochino», representación ritual de los mayas yucatecos; la fiesta de U k'in u k'a'ba' chan k’u -«El Cumpleaños del Niño Dios»-, de la parte oriental de la Península; y otras representaciones rituales tzotziles y tzeltales de Zinacantán, San Juan Chamula y Tenejapa.

Además de estas prácticas religiosas, existen en las poblaciones indias de México diversas manifestaciones de carácter mágico, se trata de «un fenómeno multirepresentativo donde todo se gobierna por sucesivas transformaciones» ${ }^{4}$. Es un teatro terapéutico relacionado con las formas rituales más antiguas de todas las culturas.

De igual manera, en el centro del país y en los estados de México, Guerrero, Morelos y Puebla se hacen representaciones comunitarias con tema histórico. Es conocida sobre todo la representación que se efectúa en el Peñón de los Baños en el Distrito Federal sobre La batalla del 5 de mayos.

Los carnavales constituyen otra forma de teatralidad cuyas características difieren según el contexto cultural donde se realice: indígena como en San Juan Chamula o mestizo como en Huejotzingo, Puebla.

Las representaciones contemporáneas, por otra parte, comparten en esencia las características de las tradicionales y se distinguen de ellas por la incorporación de nuevos contenidos, especialmente políticos, y de técnicas modernas que, en ocasiones, llegan a producir nuevas formas. Los temas tratados reiteradamente son aquellos que repercuten en la vida de la comunidad: alcoholismo, machismo, violencia, pérdida de valores tradicionales, cambio cultural, pandillas juve- niles, drogadicción, destrucción ecológica y emigración hacia Estados Unidos. Otra línea temática son los mitos y cuentos tradicionales. Algunos espectáculos incluyen o son exclusivamente de guiñol o marionetas. Es un teatro que va mas allá del sociodrama o del simple espectáculo de consumo para convertirse en un acontecimiento basado en la necesidad de representación de la comunidad; es un teatro hecho en los espacios y en los tiempos que la comunidad considera necesarios. No es un teatro en búsqueda de público, sino que su público es la propia comunidad que lo crea ${ }^{6}$.

Un ejemplo del teatro maya contemporáneo es el Grupo multigeneracional Sac Nicté («Flor Blanca») que existe desde 1977 en la región Puuc de Yucatán y está integrado por maestros, estudiantes, amas de casa y campesinos bajo la dirección de Carlos Armando Dzul Ek. Presentan sus obras en las fiestas de los pueblos de toda la península. Uno de sus trabajos más conocidos es el Auto de fe o choque de dos culturas. Según Donald Frischmann, los acontecimientos de este drama situado en 1562 siguen influyendo sobre el status actual de los mayas yucatecos. El tema se refiere a la imposición de la cultura española, específicamente al juicio en contra de los «idólatras y transgresores» de la religión católica orquestado por el provincial franciscano Diego de Landa ${ }^{7}$.

Otro grupo es Lo’il Maxil ( «La Risa de los Monos»), parte integral de Sna Jtz'ibajom, A. C. («La Casa del Escritor») de San Cristóbal de las Casas, integrado por trece hombres y mujeres tzotziles y tzeltales. Fue fundado en 1988 y entre las obras que ha realizado se encuentran: El burro y la mariposa (1988), Entre menos burros, más olotes (1989), El haragán $y$ el zopilote (1989), ¿A poco bay cimarrones? (1990), Herencia fatal (1991) Dinastía de jaguares (1992), jVámonos al paraíso! (1993), De todos para todos (1994): "Dedicada a todos los mártires Mayas y Zoques caídos en las guerras de Chiapas». El drama explora algunas de las causas detrás del levantamiento armado de enero del mismo año, así como las preocupaciones ecológicas y mágicas en torno al último refugio del indígena despojado y marginado de la tierra propia: la selva lacandona. Otra obra es Antorchas para amanecer (1995).

En su apasionada y fecunda tarea de investigador del teatro maya, Donald Frischmann ha registrado también sus manifestaciones más recientes, las del movimiento zapatista ${ }^{8}$. 
Desde las «señas», pequeñas obras en un acto, hasta los «Consejos de ancianos», que es una resignificación de un teatro ancestral, pasando por las obras históricas. La existencia de este teatro se remonta a la época prehispánica y, en la época actual, a las primeras brigadas campesinas del Teatro Conasupo de Orientación Campesina que a fines de los setenta integró tres brigadas: una tzotzil, otra tzeltal, y otra tojolabal.

En cuanto al teatro en lengua náhuatl, el grupo Nimayana («tengo hambre») de San Miguel Tzinacapan, Cuetzalan, Puebla es un claro representante del teatro como medio de reedificación, pues nació, según uno de sus integrantes "como una necesidad de abrir aquellas bocas que estaban cerradas» en la escuela secundaria abierta, a fines de los setenta. Hicieron representaciones de las obras: El hombre nuevo y In Yankuit Tit (El fuego nuevo). En su comunidad y luego fuera de ella, descubrieron el sentido del teatro al platicar con el público; para ellos «el teatro fue muy valioso, porque nos hizo avanzar a todos los que siempre estamos situados en un rincón»". También como manifestación del teatro náhuatl actual está la que promueve en la Huasteca hidalguense Ildefonso Maya. Para él

No es la fe ni los ritos cristianos los que hacen mover a las masas para esas representaciones, sino la creencia y la fe tradicional de México que vive con sus dioses, aunque desde hace más de quinientos años hayan cambiado de nombre por la fuerza de la imposición ${ }^{10}$.

Del teatro en lengua zapoteca mencionaremos que en 1981 se integró un grupo en Juchitán a instancias del departamento de teatro indígena de la UABJO. Sus integrantes nunca habían actuado ni visto obras del teatro urbano «profesional». Por lo tanto se utilizaron máscaras para que el público no reconociera a los actores y éstos pudieran actuar con libertad. Representaron obras como Tierra y fuego sobre problemas ocurridos en 1717 , fecha en la que unos religiosos arrebataron tierras a los zapotecas de Juchitán, otra sobre el «che» Gómez (líder juchiteco en 1911) y Juchitán en el tiempo (historia de la vida social zapoteca de 1660 a 1983$)^{11}$.

El grupo Tehuantepec nació en 1987 en el istmo del mismo nombre como una necesidad comunitaria de expresar a través del teatro elementos y valores propios de su tradición, cultura y problemática social. Formó parte de la Asociación Nacional Teatro Comunidad (TECOM). Uno de sus espectáculos más significativos fue $\mathrm{La}$ llorona que representó a México en el Festival de Teatro Latinoamericano de Córdoba, Argentina, en 1994.

Los grupos que formaron parte de TECOM, fundada en 1987, y aquellos que aún participan en el movimiento de teatro comunitario, intentaban convertirse en monitores de su propia cultura. Su modo de producción tomó como base la «metodología de investigación-acción participativa», fundamentada en la interacción del grupo de teatro y su comunidad. Los mismos miembros

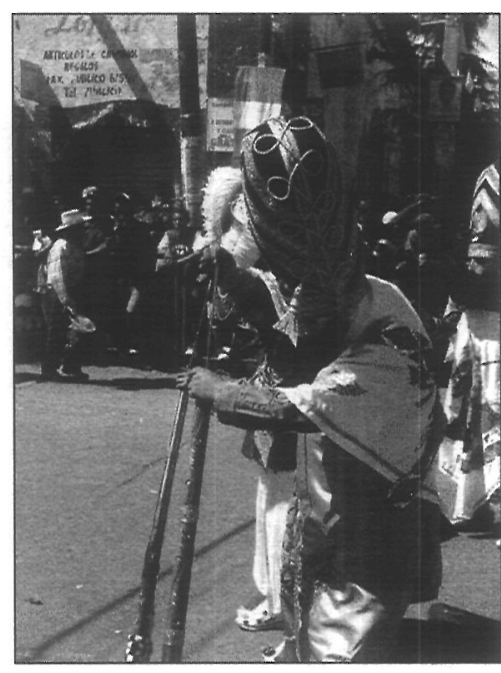

Danzante del Carnaval de Huejotzingo. de la comunidad participaban en el espectáculo, ya fuera como actores, aportando en el proceso de producción aspectos referidos al material dramático (temática, conflicto) o bien colaborando con la realización de escenografía, utilería o vestuario. De tal manera que la apropiación de la experiencia fortalecía el desarrollo de las comunidades indígenas, campesinas o urbanas populares.

Otra experiencia contemporánea es la que dio inicio en 1983 en Oxolotán, Tabasco. Se trata de un proyecto de formación, creación y difusión que, por diversos motivos, llamó la atención de propios y extraños, entre otras cosas por los altos presupuestos que manejó y por el dispendio en viajes y auto-promoción a Europa y los Estados Unidos. En 1985 el Laboratorio de teatro campesino e indígena trabajaba en siete comunidades con 1,700 alumnos y 32 maestros, o sea la escuela de teatro más grande del mundo. El proyecto, segûn una integrante del equipo directivo, se decidió mediante «consulta popular» en 20 comunidades del estado:

Fuimos a preguntarles ¿qué querían hacer en su tiempo libre? Si querían bailar, cantar, tocar la guitarra...lo que ellos quisieran nosotros íbamos a llevarles. Entonces, de estas 20 comunidades destacó Oxolotán que con una investigación de, digamos el $80 \%$ de su población, el 75 contestó que quería hacer teatro (sic) $)^{12}$.

\section{Un reportaje de 1991 consignaba:}

Con el apoyo irrestricto de la escritora Julieta Campos, entonces presidenta del DIF (Desarrollo Integral de la Familia) de la entidad nació el Laboratorio de Teatro Campesino e Indígena de Tabasco [...].
9

Moisés Castro Payno, Eulalia et al., «El teatro de San Miguel Tzinacapan no ha muerto, vive en las organizaciones", Memoria del Encuentro en torno al teatro rural. México, Teatro Rural/Dirección General de Culturas Populares/SEP, 1985 [copia mimeográfica, sin paginación].

\section{0}

Ildefonso Maya, "El teatro masivo indigena, base del teatro mexicano» en Memoria del III Encuentro de Investigación Teatral, México, CITRU-INBA, 1992 págs. 15-24.

11 Macario Maius, "Teatro en lengua zapoteca», Memoria del Encuentro en torno al teatro rural. México, Teatro Rural/ Dirección General de Culturas Populares/SEP, 1985 [copia mimeográfica, sin paginación].

12

Lourdes Arriaga y Santos Pisté Canche en Memoria del Encuentro en torno al teatro rural, México,Teatro Rural/Dirección General de Culturas Populares/ SEP, 1985 [copia mimeográfica, sin paginación]

Teatralidad india y comunitaria en México. Un acercamiento desde la complejidad

DOMINGO

ADAME HERNÁNDEZ Chávez Tomás, Blas Soto Islas, 


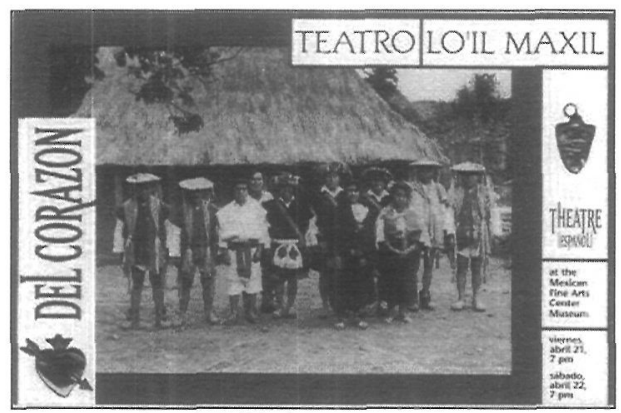

Cartel anunciador grupo Lo'il Maxil.

13

Magdalena Molina, «Teatro campesino e indígena. El despertar del jaguar», Memoria de Papel, núm.1, CNCA, México, pág. 103.
Teatralidad india y comunitaria en México. Un acercamiento desde la complejidad DOMINGO ADAME HERNÁNDEZ
Seis años después, en 1989 el LTCI contaba ya con una primera generación de ciento veintitrés maestros de teatro y tres mil alumnos formados con la técnica Stanislawski, la biomecánica -enseñanza simultánea de ritmos diferentes para liberar la expresión corporal-, y un programa de 31 materias más. En este lapso se conformó un repertorio de 43 obras teatrales, que incluyó una creación colectiva de los integrantes del laboratorio: La tragedia del jaguar, así como obras de autores nacionales contemporáneos, y piezas universales como Bodas de sangre de Federico García Lorca ${ }^{13}$.

Frente a esto, es legítima la pregunta sobre el carácter campesino y/o indígena del proyecto, pues lo que predomina es el teatro occidental. Para lo que sin duda sirvió fue para difundir -una vez más- en el extranjero y ante los propios connacionales la imagen folklórica de México, es decir, fortaleció la normalización del imprinting cultural autoritario, manipulador y populista de los gobiernos emanados de la Revolución. Es evidente que los llamados «Laboratorios de Teatro Campesino e Indígena» siguieron pautas de creación y producción ajenas al contexto propio y que constituyeron iniciativas gubernamentales para manipular y postergar el genuino avance comunitario.

\section{VARIABLES DEL TEATRO INDIO Y COMUNITARIO EN MÉXICO}

En un afán por sintetizar las distintas formas de esta teatralidad, enumero las siguientes variables:

1. Teatro hecho por miembros de una comunidad, en la comunidad y para la propia comunidad. Se trata, sobre todo, del teatro ritual en el cual no hay distinción entre actores y espectadores.

2. Teatro hecho por miembros de una comunidad, en la comunidad y para distintas comunidades, por ejemplo el teatro religioso como $\mathrm{La}$ pasión de Cristo que en los últimos años ha adquirido carácter comercial. Esto genera en el público el interés de hacer su propia «Pasión»y, en consecuencia, se establece un espíritu de competencia. En el lado opuesto están los grupos de Teatro-Comunidad surgidos en los últimos años donde se establece un tipo de intercambio entre grupos; el público, aunque distinto, tiene rasgos comunes, la agrupación no resulta del todo ajena.

3. Teatro hecho por miembros de una o varias comunidades, fuera de la comunidad y para distintas comunidades. Es el caso del teatro patrocinado por instituciones de gobierno, religiosas o políticas que capacitan a personas de comunidades indígenas y campesinas para hacer un teatro de carácter didáctico.

4. Teatro hecho por personas ajenas a las comunidades, en la comunidad y para presentarse en varias comunidades. Se trata de grupos formados por jóvenes provenientes de centros urbanos que llegan a comunidades indígenas con el propósito de integrarse a ellas, de vivir de acuerdo a sus costumbres las cuales «recrean artísticamente» para resaltar sus tradiciones.

5. Teatro hecho por personas de la comunidad, en la comunidad y para distintas comunidades, pero con intereses distintos a los de la comunidad. Es el caso del teatro patrocinado por instituciones de gobierno, religiosas o políticas que realizan trabajos o se presentan en comunidades indígenas o campesinas sin reflejar el proyecto o las condiciones de las propias comunidades. Por ejemplo, el Teatro Campesino e Indígena de Tabasco.

\section{SENTIIDO DEL TEATRO INDIO Y CO- MUNITARIO}

Considero que cualquier intento por acercarse al teatro indio y comunitario debe tener en cuenta el sentido que para las propias comunidades tienen las representaciones. Menciono, en seguida, dos señalamientos producto de la práctica y la investigación directa.

German Meyer, investigador, creador y participante activo del movimiento del Nuevo Teatro Popular en México entre 1976 y 1986, considera que más que un espectáculo en sí, en el cual se abre [un] «espacio vacío» que un autor, un director y unos actores van a tratar de llenar para un espectador que viene a «mirarse». Podemos vislumbrar desde un principio el teatro indio como un campo «lleno» de fuerza, que recibe su energía de 
muchos polos y la redistribuye a muchos otros. Nada más extraño a una concepción del teatro indígena, dice

...que la noción de un teatro en la que se encierra uno para enterarse de lo que a alguien se le ha ocurrido manifestarnos. Aquí todo está arreglado: los polos que producen la energía pueden ser tanto el calendario como la tradición, el mayordomo, la manda, el placer del juego o de la necesidad; algunos de los polos que se benefician con esta energía podrían ser la cohesión social, las buenas relaciones con los dioses, la integración de una personalidad y de una identidad. Más que un «espacio vacío», se entiende entonces que este teatro necesita de un «espacio lleno» de simbología, de valores sociales, de tradiciones artísticas. Y este [espacio] lo ofrecen no solamente los actores que son del mismo pueblo o de la misma cultura, no solamente las obras que son las mismas año tras año, no solamente la puesta en escena o la coreografía que se transmite por tradición y no se inventa en cada función, sino también, y sobre todo un «espacio lleno» de la seguridad de un sentimiento o de la confirmación de una visión del mundo. El teatro deja de ser entonces un producto que se consume o no: es el espejo de un rostro inalterable ${ }^{14}$.

\section{Por su parte, Donald Frischmann indica:}

En el teatro comunidad actores rituales emplean coreografía, música y cantos, máscaras, vestuarios y objetos rituales. Todo movimiento, palabra, motivo y color ha sido cuidadosamente seleccionado y elaborado para elaborar los fines mágicos deseados. El objetivo primordial de los participantes es entrar en comunicación con las fuerzas del cosmos, asumiendo así el papel de mensajero y abogado de la comunidad ante las fuerzas mayores. Cuando la comunidad entera asiste a tales representaciones es en calidad de coadjutor y no como espectador, ya que los destinatarios intencionados son las deidades mismas. Por lo tanto, la estética que se persigue en las representaciones ritualísticas responde a motivaciones cosmogónicas y es traducida por los ejecutantes en aquellos elementos visuales y sonoros que mejor puedan complacer al destinatario sobrenatural y así lograr los fines deseados. Tales manifestaciones culturales, rituales y estéticas surgen del «México profundo» que para Bonfil Batalla está constituido por una gran diversidad de pueblos cuya manera de entender el mundo y organizar la vida tiene su origen en la civilización mesoamericana prehispánica. En este contexto se inserta el teatro comunidad que es una experiencia escénica y de promoción comunitaria en la que se crea o recrea manifestaciones dramáticas y representacionales, por y/o para los miembros de comunidades indígenas, campesinas o urbano-populares ${ }^{15}$.

\section{EL CONCEPTO «COMUNIDAD» DESDE UNA PERSPECTIVA COMPLEJA}

Entiendo por comunidad la agrupación de individuos que comparten aspectos culturales fundamentales de tipo social, religioso y estético. En cuanto a lo social podemos mencionar comunidades lingüísticas, geo-políticas, económicas, políticas, profesionales, sexuales, educativas, etcétera. Al respecto de lo religioso habría que considerar a las diversas religiones $\mathrm{y}$ a todas las sociedades culturales; por último, en lo que se refiere a lo estético, habría que incluir a las comunidades artísticas, de intelectuales y de artesanos, por citar algunas. Si bien en todos los casos existe un elemento común que les otorga el carácter de «comunidad», el resto de los elementos «culturales» de los individuos que la forman son, casi siempre, diferentes. Unidad y diversidad es el binomio que identifica a la comunidad. Habría que preguntar cuál es el elemento que permite la cohesión, pues, sin duda, el mayor problema es cómo hacer que exista verdadera unidad más allá de las diferencias. Este elemento indispensable es la ética que consiste en la valoración del ethos, del ser, de los derechos de la persona a una vida con dignidad. La ética, además de ser un elemento cohesionador de cada comunidad, permite la convivencia entre las distintas comunidades. De este modo podemos decir que una comunidad es aquella cuyos miembros comparten una ética. O dicho de otra manera, la ética comunitaria es la que permite la interacción de los individuos al interior de su comunidad y fuera de ella -en otras comunidades- es decir en el mundo ${ }^{16}$.

No tener sentido de comunidad es vivir defendiendo sólo una visión de la realidad y rechazando otras diferentes; es propiciar los nacionalismos, los fascismos, las intolerancias, los racismos y las discriminaciones. Por el contrario, tener un sentido de comunidad es reconocer la multiculturalidad, ser tolerante y respetuoso de las diferencias sin anteponer $y$, menos aún, querer imponer el punto de vista propio a otras comunidades. Lo primero es ignorancia, lo segundo exige conocimiento y amor hacia lo humano y a todo lo que existe. Podría decirse que estamos hablando de una comunidad ideal y, por lo tanto, inexistente. No es así, en todo caso lo que señalamos son las metas a las que toda comunidad puede aspirar. Reconocemos, pues, que existen di-
14

German Meyer, «El teatro en las fiestas indígenas», Memoria del Encuentro Nacional en torno al Teatro Indígena y Campesino, Teatro rural/Dirección General de Culturas Populares/SEP, México, 1985 [copia mimeográfica, sin paginación].

15

Donald Frischmann, «El teatro de comunidad en México: teoría y praxis», en Entorno, nuevo época, núms. 56-57, págs. 3643.

16

La definición del compromiso ético de Bach y Darder cierran perfectamente el círculo de lo aquí expresado: "saber que lo que hago y cómo lo hago tendrá una repercusión sobre mí mismo, sobre el otro y sobre el entorno y por tanto lo tengo en cuenta, lo pienso y actúo procurando que esta repercusión sea lo más positiva posible...no disfrazo la realidad a mi conveniencia, ni me instalo en el inmovilismo». Eva Bach y Pere Darder, Desedúcate. Una propuesta para vivir y convivir mejor, Paidos, México, 2005, pág. 76.

Teatralidad india y comunitaria en México. Un acercamiento desde la complejidad

DOMINGO

ADAME HERNÁNDEZ 


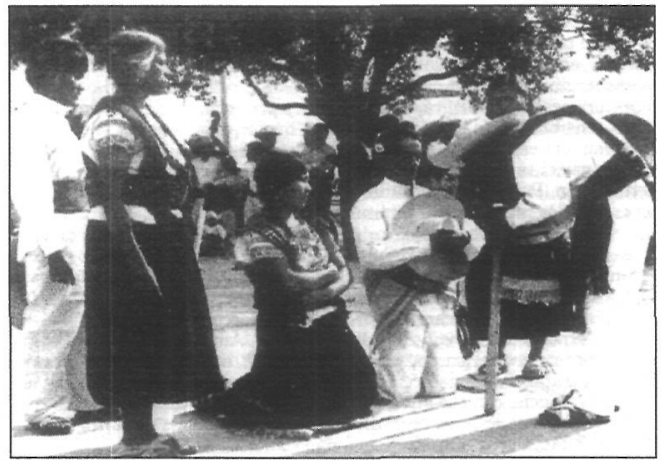

Brigada Xicotencatl (Tlaxcala). versas etapas para llegar a alcanzarlas, pero lo que no puede perder de vista cada miembro de la comunidad es la actitud ética. Sin ella sería imposible impulsar un movimiento de teatro comunitario, pues para que éste exista debe surgir de las convicciones más auténticas de las mujeres y los hombres que buscan expresar, creativa y sensiblemente, su pertenencia a una comunidad y su deseo de convivir y compartir experiencias con otras diferentes a ella.

Es necesario, por lo tanto: a) Contar con una concepción amplia del concepto «comunidad» que dé cabida a todos aquellos grupos $\mathrm{e}$ individuos que, sin importar sus condiciones geográficas, étnicas, políticas, sexuales, etcétera, deseen expresar un sentir comunitario; b) Aspirar a la formación de la persona comunitaria: tolerante y respetuosa de las diferencias $\mathrm{y}$, sobre todo, respetuosa de la vida humana y de la naturaleza; c) Estimular la pluralidad en la creación sin imponer a ninguna comunidad el teatro que se considere que es el más conveniente para ella.

El teatro comunitario fortalece al individuo en una nueva relación consigo mismo, con su comunidad y con los otros. Un teatro que logre integrar a su público en una unidad derivada de sus orígenes será el teatro imprescindible para lograr los ideales de la democracia incluyente.

\section{EL CONCEPTO «TEATRO» EN UNA PERSPECTIVA COMPLEJA}

Todos los grandes momentos del teatro universal en oriente y occidente han surgido de un vínculo estrecho entre las dimensiones ética, estética y religiosa de lo humano. El teatro ha sido siempre un medio para confrontar la realidad del hombre, para lo cual se requiere disposición para enfrentar las coacciones que lo oprimen. Lo que resulta de ello es una mejor comprensión de la realidad y una redimensión de la complejidad del hombre. Por ello el teatro es, ante todo, una forma de conocimiento. Conocimiento de las fuerzas que mueven al mundo y de las relaciones del hombre consigo mismo y con los demás.

La sociedad contemporánea parecería no estar muy interesada en este tipo de experiencias a través del teatro. El afán por obte- ner satisfacciones inmediatas ha empobrecido considerablemente a nuestra sociedad. ¿En dónde puede encontrarse entonces una fuente que alimente al teatro de nuestro tiempo y del porvenir? La respuesta surge de manera inmediata: en la tradición y en las preguntas fundamentales que el hombre puede hacerse sobre su existencia. Intentaremos enseguida explicar estas dos ideas.

Considerar a la tradición como fuente del nuevo teatro no significa remontarse al pasado con un sentimiento de nostalgia y querer revivir en el presente lo que ya fue. Significa reconocernos como parte de un proceso cultural que no comenzó con nuestra propia persona, sino que se ha conformado con las aportaciones de múltiples generaciones y del cual, queramos o no, somos continuadores. El reto, entonces, es actualizar permanentemente la tradición, ser conscientes de ella para no repetirla de modo inútil, o romperla o cancelarla sin darnos cuenta, pues cualquiera de estas actitudes significaría reducir una parte fundamental de nuestra condición humana.

Referirse a la «tradición» requiere de otra precisión: es más conveniente hablar de «tradiciones». Es evidente que si bien la condición humana es una sola, el hombre forma parte de muy diversas prácticas entre ellas las teatrales. En México, hemos dicho, las tradiciones culturales y teatrales distan mucho de ser homogéneas y su relación está claramente diferenciada desde una perspectiva ideológica. Entonces, surge otro problema. ¿A qué tradición se debe o se puede uno ligar? En términos generales, a aquella que sea capaz de superar las diferencias superficiales entre los hombres para ir a las coincidencias más profundas. Esta especie de depuración ideológica y teatral requiere ante todo del conocimiento. En nuestros días, una mujer o un hombre que se dedique al teatro no pueden permanecer ajenos al mundo que lo rodea. La falta de información y de reflexión limita el campo de la visión y conduce a otorgar validez sólo a lo que tenemos frente a nosotros. El acceso a la información que genere la reflexión y la creación requiere, sin embargo, de un primer paso fundamental: la decisión de comprometerse vitalmente con el teatro, y esto no quiere decir ni hacer del teatro un medio de subsistencia como cualquier otro, ni entregarse a él románticamente sin esperar recompensa alguna. Comprometerse vitalmente con el teatro significa-desde mi punto de vista- que puedo entender la difícil y amplia tarea que entraña la creación teatral; que puedo comprender su 
enorme significación social; que sé que puedo serle útil asumiendo, con generosidad y entusiasmo alguna de las tantas funciones de que se compone; que puedo contribuir para que otros como yo encuentren en el teatro algunas respuestas a sus interrogantes y también, por supuesto, para que logren una experiencia placentera que, por serlo, permanecerá y será siempre productiva. Se trata, como puede verse, de una cuestión ética y estética que exige un mayor compromiso con lo humano.

\section{PROPUESTA ECOPOIÉTICA}

Para concretizar las reflexiones anteriores es necesario considerar aspectos teórico-metodológicos provenientes de la epistemología de la complejidad, a fin de establecer relaciones pertinentes entre diversos conocimientos que den cuenta del fenómeno en su conjunto. Propongo, por lo tanto, una estrategia transdisciplinaria y «ecopoiética» apta para integrar dinámicamente la multiplicidad de expresiones representacionales de una sociedad pluricultural como la mexicana y, a éstas, con otras del mundo.

Uno de los mayores obstáculos al que nos enfrentamos los investigadores es el de la atomización de los saberes, por eso la transdisciplinariedad es una alternativa pertinente, ya que hace emerger de la confrontación de las disciplinas nuevos datos que las articulan y nos ofrecen una nueva visión de la naturaleza y de la sociedad. Además, dentro del conocimiento académico, es común que se subestimen las implicaciones corporales y cognoscitivas de lo que implica este cambio epistémico y cosmogónico hacia el pensamiento complejo y la transdisciplina. Distintas formas de sabiduría perenne y tradicional han practicado desde hace milenios un desarrollo de saberes locales y universales sobre la base de la ruptura de la dualidad sujeto-objeto. La investigación tradicional practicada por los pueblos aborígenes ha generado saberes de infinita complejidad. Dicha investigación tradicional se forja desde una corporeización de la experiencia cognoscitiva, desde un cuerpo que siente, que vibra y ama. Se trata de una articulación de vivencias y saberes, donde se gesta el conocimiento complejo, trascendente y planetarizado; un saber holográfico sagrado. Así, la ruptura de la dualidad es posible a través de la corporeización de la experiencia cognoscitiva.

La ecologización del pensamiento nos lanza hacia la inaplazable necesidad de cor- poreizar y emocionear el conocimiento (incorporar el cuerpo y las emociones al acto de saber: entrar en un conocimiento somático). Para ello nos parece indispensable acercarnos nuevamente al mito y al rito, no desde una nueva racionalización, lo cual constituiría una necedad reiterativa de regreso a nuestros viejos vicios, sino desde el Ser-Cuerpo que es el espacio privilegiado, el hogar de la mitopoiesis. La crianza de habilidades cognoscitivas-emocionales mediante un elaborado escenario de rituales y mitos permite el cruce de sensaciones, donde los olores, el tacto, los sonidos, la vista y el gusto son contrastados dentro de una compleja cosmogonía. El acto ritual es concebido como el espacio donde el mito integra compleja y holográficamente la infinita trama de las relaciones personalescomunitarias-planetarias.

Mi propuesta se encamina precisamente en este sentido: coadyuvar a la creación de espacios de transformación y de empoderamiento personal, de recomunalización o comarcación, a través de la puesta en práctica de procesos eco-poiético-rituales, los cuales se articulan con procesos de creatividad comunitaria orientados a la transformación social. Esta opción se construye retomando y recreando particularmente la cosmogonía de nuestros antiguos pueblos mesoamericanos y estableciendo un diálogo entre las diversas sabidurías de los pueblos milenarios, los saberes locales tradicionales y la ciencia ecologizada y sacralizada. Afirmo desde mi experiencia de comarcación y co-construcción de alternativas al desarrollo, que estos espacios y praxis eco-poiético-rituales permiten abordar de forma creativa y exitosa problemas centrales de la convivencia social, tales como el poder, la feminidad-masculinidad, la generación de saberes locales, los conflictos, los procesos de cambio, la creatividad, la violencia, etcétera. El reencuentro con la experiencia de lo sagrado -lo cual se vive en los rituales no secularizados- es central en la generación de los procesos de transformación y de comarcación. El contacto con lo sagrado nos permite trascender el sentido de separatividad y acceder a lo «numinoso", es decir a la profundidad de la experiencia vital, de la relación con la naturaleza, con nosotros mismos y con nuestro entorno. Es lo que permite reintegrar la dimensión espiritual del ser humano, al mismo tiempo que lleva a reajustarnos a los patrones de la naturaleza y a restituir el ritmo hacia nosotros mismos, hacia el entorno y hacia el cosmos y, de esta
Teatralidad india y comunitaria en México. Un acercamiento desde la complejidad DOMINGO ADAME HERNÁNDEZ 
manera, re-crear un pulso y un ritmo comunitario hacia un mundo posible: la utopía holográfica y sagrada de una Transformación Social Espiritual.

Confío que al establecer un diálogo complejo, transdisciplinario y ecopoietico entre teatralidades tradicionales y contemporáneas, sagradas y profanas, prosaicas y poéticas, dogmáticas y liberadoras será posible reconocer las matrices culturales que son fuente inagotable de creación, desde donde puede emerger la autonomía espiritual de cada persona.

\section{BIBLIOGRAFÍA}

Acosta Báez, Francisco, «Teatro comunidad», La escena latinoamericana, nueva época, 5/6, págs. 52-57.

Arriaga Lourdes y Santos Pisté Canche, «EI laboratorio de teatro campesino e indígena de Tabasco», en Memoria del Encuentro en torno al teatro rural. México,Teatro Rural/Dirección General de Culturas Populares/SEP, 1985 [copia mimeográfica, sin paginación].

Bach, Eva y Pere Darder, Desedúcate. Una propuesta para vivir y convivir mejor, México, Paidós, 2005.

Castro Payno, Moisés, Eulalia Chávez Tomás, Blas Soto Islas, et al., «El teatro de San Miguel Tzinacapan no ha muerto, vive en las organizaciones», Memoria del Encuentro en torno al teatro rural. México, Teatro Rural/Dirección General de Culturas Populares/SEP, 1985 [copia mimeográfica, sin paginación].

Frischmann, Donald, «El teatro de comunidad en México: teoría y praxis», en Entorno, nueva época, núms. 56-57, págs. 36-43.

- , "El teatro en las comunidades zapatistas de Chiapas», Investigación teatral, núm. 3 , págs. 13-21.
-, «Etnicidad activa: nativismo, otredad y teatro indio en México", Memoria del III Encuentro Nacional de Investigación Teatral, México, CITRU-INBA, 1992, págs. 25-34.

Jiménez Castillo, Manuel, «Investigación sobre teatro indígena y campesino. Un punto de vista antropológico", en Memoria del III Encuentro Nacional de Investigación Teatral, México, CITRU-INBA, 1992, págs. 42-52.

Matus, Macario «Teatro en lengua zapoteca», Memoria del Encuentro en torno al teatro rural. México, Teatro Rural/ Dirección General de Culturas Populares/SEP, 1985 [copia mimeográfica, sin paginación].

Maya, Ildefonso «El teatro masivo indígena, base del teatro mexicano» en Memoria del III Encuentro de Investigación Teatral, 1992, México, CITRU-INBA.

Meyer, German, «El teatro en las fiestas indígenas», Memoria del Encuentro Nacional en torno al Teatro Indígena y Campesino, Teatro rural/Dirección General de Culturas Populares/SEP, México, 1985 [copia mimeográfica, sin paginación].

Molina, Magdalena, «Teatro campesino e indígena. El despertar del jaguar», Memoria de Papel, núm. 1, CNCA, México, pág. 103.

Morin, Edgar, «El pensamiento subyacente» en El Método IV, Las ideas, Madrid, Cátedra, 1992.

Toor, Frances, A treasury of Mexican Folklore, New York, Crown, 1947.

Weisz, Gabriel, «La piel mágica de los dioses», Memoria del Encuentro de Teatro Rural, México, Dirección General de Culturas Populares/SEP, 1985 [copia mimeográfica, sin paginación].
Teatralidad india y comunitaria en México. Un acercamiento desde la complejidad

DOMINGO

ADAME HERNÁNDEZ 


\title{
LA FIESTA VERDADERA: :UNA REALI- ZACIÓN FELIZ EN EL TEATRO? LUCES Y SOMBRAS DE LOS ENCUENTROS DE TEATRO COMUNITARIO EN MÉXICO
}

\author{
ELIZABETH ARAIZA HERNÁNDEZ
}

\section{RESUMEN}

A partir de la restitución al teatro en su función primordial de religar a los seres humanos y proveerles de una experiencia ritual y festiva, se lleva a cabo la descripción y análisis de diversos encuentros convocados por la asociación de Teatro Comunitario en México diferenciándolo del conjunto del teatro popular, universitario, rural, indígena y campesino.

La interpretación que aquí se presenta se apoya en un trabajo de observación directa llevado a cabo durante varios años (1992-2000), en diversos poblados, en varias situaciones de representación y en numerosas conversaciones con las personas que participan en estos eventos: organizadores, actores, espectadores y habitantes de las comunidades donde se ha realizado.

\section{THE REAL FEAST: A HAPPY DRAMA PRODUCTION? LIGHTS AND SHADOWS IN COMMUNITY THEATRE EVENTS IN MEXICO}

\section{ABSTRACT}

Using the return to the primordial function of theatre as a way to bring people together and provide them with a ritualistic and festive experience as a basis, a description and analysis of different events beld by the Community Theatre Association in Mexico are given, differentiating it from popular, academic, rural, indigenous and peasant theatre.

The interpretation given here is based on direct observation work carried out over many years (1992-2000) in different locations, with varied representational situations and numerous conversations with those taking part in the events: organisers, actors, spectators and inhabitants of the communities where the performance was beld.

La noción de fiesta ha guiado numerosas experiencias teatrales, sobre todo aquellas que se proclaman populares o alternativas, experimentales o no-oficiales. Dos de los imperativos de este tipo de teatro han con- ducido a mistificar una cierta concepción de fiesta, la de la «fiesta verdadera», la fiesta patronal. El primer imperativo, de algún modo presente en toda experiencia teatral, es el de abarcar un público amplio y diverso.

\section{Elizabeth Araiza Hernández}

Investigadora docente en el Departamento de Sociología de la Universidad de Perpignan (Francia). Miembro del laboratorio de Investigaciones en Etnoescenología de la Maison des Sciences de l'Homme. Paris-Nord. Recibió una formación disciplinaria en Etnología en la Escuela Nacional de Antropología e Historia de México, donde impartió además cursos de 1991 a 1993. Su trabajo se sitúa en la intersección de varias disciplinas: antropología del arte, antropología del ritual, antropología performativa (performance studies), estudios teatrales, socio-antropología del cuerpo y etnoescenología. Se ha dedicado al estudio del teatro indigena contemporáneo a partir del vínculo que éste establece con otras formas de representación, principalmente el ritual, el juego, el trabajo y los mitos. Doctorada en la Universidad de París 8, su tesis Sous le signe de l'entre deux: anthropologie du théâtre amérindien au Mexique está en vías de publicación (Presses Universitaires de Bordeaux); ha publicado, además, numerosos artículos sobre este tema y sobre los problemas metodológicos de la antropología del teatro.
La fiesta verdadera: zuna realización feliz en el teatro? Luces y sombras de los encuentros de teatro comunitario en México ELIZABETH ARAIZA HERNANDEZ 


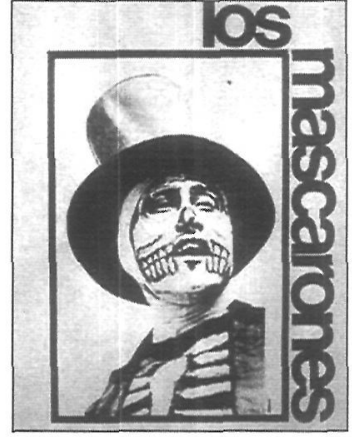

Cartel anunciador de Las calaveras de Posada. Grupo Mascarones.

1

Henri Gouhier, L'essence du théâ tre, París, Aubier-Montaigne, «Présence et pensée», núm. 11 , 1968, pág. 259. La traducción de todas las citas que aparecen en este texto y que originalmente fueron publicadas en francés, es mía.

2

Para obtener más detalles sobre la fiesta de Tlaltenango en Cuernavaca, ver Héctor Rosales Ayala, Tlaltienango: las transformaciones del sentido de una fiesta popular, México, UNAM-CRIM, 1988; sobre el grupo Cultural Mascarones y el teatro del grupo Zero, ver Donald Frischman, El nuevo teatro popular en México, México, CITRU-INBA, 1990; y, sobre el teatro relacionado con la Teología de la Liberación, ver Adam Versényi, El teatro en América Latina, Nueva York, Cambridge University Press, 1996.

La fiesta verdadera: cuna reali- $^{-}$ zación feliz en el teatro? Luces y sombras de los encuentros de teatro comunitario en México

ELIZABETH

ARAIZA HERNÁNDEZ
El segundo es el de un regreso a los orígenes rituales y festivos del teatro. Un regreso a los orígenes implica, desde esta óptica, restituir al teatro su función primordial que es la de religar a las personas, proporcionarles una experiencia ritual y festiva. Para conjurar el vacío, el no-ser que amenaza a cada momento toda representación teatral, se acude con insistencia a la fiesta. Es así porque «la representación dirigida a una sola persona constituye una aberración, [porque] el vacío introduce en el teatro un principio de no-ser que compromete su operación decisiva» ${ }^{1}$. Vistas así las cosas, resulta que la participación masiva, unánime y entusiasta que genera la fiesta suscita al mismo tiempo una comunión entre actores y espectadores, quedando la frontera que los separa, en condiciones nofestivas, por completo abolida. Todo sucede como si la convergencia de los cuerpos fuera equivalente a una convergencia de las creencias y de las emociones, como si estar juntos fuera lo mismo que estar unidos.

\section{LAS ESTRATEGIAS DEL TEATRO CO- MUNITARIO PARA REPRODUCIR LA FIESTA}

Si se ponen en perspectiva los encuentros que cada año convoca la asociación civil u otras agrupaciones de teatro comunitario en México, se podrá constatar la existencia de tres estrategias principales tendientes a reproducir la fiesta. La primera consiste en integrar obras de teatro en la fiesta, o bien introducir un festival teatral en el marco general de la fiesta. La segunda consiste en utilizar los sistemas de organización social que rigen la fiesta (gremios, sistema de cargos) para constituir y dinamizar el proceso teatral: conformación del grupo, regularidad en la creación, la difusión, la recepción. La tercera estrategia consiste en investir el encuentro teatral o el festival de teatro con los signos característicos de la fiesta (objetos simbólicos, acciones corporales, discursos). Desde esta perspectiva se evidencia que, en el Teatro Comunitario, las dos primeras estrategias continúan en estado de proyecto ya que no han logrado desplegarse como prácticas sistemáticas y permanentes. Desde su emergencia como conjunto asociativo, el teatro comunitario ha buscado con insistencia una integración permanente del teatro en el marco de las fiestas locales, privilegiadamente en la fiesta patronal, de tal manera que la obra teatral se convierta en un elemento constitutivo de las actividades festivas, al mismo título que por ejemplo, la procesión, la misa, la quema del castillo y de los toritos, la danza tradicional, el «jaripeo» o la corrida de toros.

Hasta donde he logrado indagar, son escasos en México los grupos teatrales que han logrado una incorporación orgánica, esto es, sistemática y permanente, de sus producciones artísticas en la fiesta patronal. El caso del Grupo Cultural Mascarones parece más representativo de una excepción que de una regla. La fiesta dedicada a la Virgen de los Remedios, tutelar de Cuernavaca, incluye desde los años 1970 un programa cultural con obras teatrales ${ }^{2}$. Si un proyecto de esta naturaleza se hizo posible, es gracias a la regularidad con que se presentan las obras teatrales y a la presencia constante del Grupo Cultural Mascarones en el barrio. Así, una de las expectativas de los feligreses, de los visitantes y del público en general al asistir a la fiesta es presenciar las obras de teatro de este grupo. Esta iniciativa resulta tanto más sorprendente cuanto el contenido de las obras teatrales no sólo no corresponde con los contenidos generales de la fiesta sino que incluso parece contradecirlos. Se trata, en efecto, de obras explícitamente contestatarias de crítica social y política. Los contenidos deliberadamente subversivos del teatro no son impedimento para su integración en el marco de la fiesta, cuyos contenidos, en apariencia, reafirman y preservan un orden social y religioso. En el fondo, los contenidos mismos de la fiesta tradicional religiosa fueron trastocados, en esta misma época en que inicia el teatro, gracias a la presencia en Tlaltenango de militantes o simpatizantes de la Teología de la Liberación. No sólo el teatro obtiene un beneficio de esta situación, logrando atraer para sí un público multitudinario y entusiasta, sino que también la fiesta sale ganando con el carácter peculiar que éste le imprime.

La segunda estrategia no se centra tanto en la estructura de la fiesta como en los sistemas de organización social que la hacen posible, esto es, los gremios, el sistema de cargos, las asociaciones religiosas. La atención se enfoca más precisamente en el sistema de cargos, que rige la mayoría de las fiestas patronales y los sistemas rituales en el medio indígena. Resulta bastante revelador el hecho de que, después de varias tentativas, se lograra que en 1998 la VII Fiesta Estatal de Teatro Comunitario, celebrada en San Juan Tabàa, fuera organizada por el sistema de cargos de este pueblo zapoteco situado en la sierra de Oaxaca. Se 
trata, sin embargo, de una experiencia que se produjo una sola vez en la historia de esta asociación. Desde esta lógica de razonamiento resulta que, si cada una de las etapas del proceso teatral es regida por el sistema de cargos, se puede garantizar con ello una integración permanente en la fiesta $y$, al mismo tiempo, una continuidad del grupo teatral.

A pesar de la influencia tan grande que ejercen este tipo de experiencias, en que la organización de la actividad teatral queda regida por el sistema de cargos, éstas resultan ser más bien escasas. Un caso relevante a este respecto es el de San Miguel Cajonos, pueblo zapoteco situado en las montañas del estado de Oaxaca. Si el teatro es parte constitutiva del sistema festivo de este pueblo, se debe a un largo proceso cuyo inicio remonta a los años 1920. La actividad teatral no sólo ocupa un lugar importante en la fiesta principal sino que además cumple una función ritual, es iniciación al sistema de cargos ${ }^{3}$. Cabe precisar que uno de los requisitos para ocupar el primero de los cargos de este sistema (el de topil) es que los jóvenes aspirantes se ejerciten como actores en, al menos, una de las obras teatrales que se presentan durante la fiesta. El sentido ritual aquí no apela tanto a una creencia o a un estado de espiritualidad o de emoción como a una dimensión performativa, pragmática. Es la práctica ritual y festiva y no la creencia lo que marca la pertenencia del individuo a este pueblo y a este grupo étnico. Para ser considerado miembro de esta comunidad zapoteca, el individuo tiene que ocupar un cargo en dicho sistema y, para acceder a éste, se necesita haber atravesado el umbral marcado por la práctica teatral. Con su desempeño en el teatro, con su interpretación de un personaje, los jóvenes sanmigueleños están mostrando ser capaces de ocupar un cargo y estar listos para hacerlo. Se trata sin duda de un caso que los miembros de la asociación de teatro comunitario han erigido en modelo, sin que logren hasta ahora desplegarlo de modo regular.

La tercera, en cambio, es la estrategia que se aplica con mayor regularidad en los encuentros de Teatro Comunitario. En las páginas que siguen, presento una descripción del modo concreto en que se lleva a cabo. En un segundo momento intentaré identificar las razones por las cuales el ideal de fiesta que esta asociación transmite no se materializa en la práctica. Esto es, me propongo aportar elementos de reflexión para comprender por qué en estos encuentros no hay una realización feliz de la fiesta ${ }^{4}$.
Lo anotado hasta ahora exige una serie de precisiones. En primer lugar, resulta claro que, si se comparte la noción vaga e imprecisa de teatro comunitario con los miembros de la asociación que lleva este apelativo, se afirmará que en éste sí hay una realización feliz de la fiesta. Los casos que acabo de comentar (Grupo Cultural Mascarones y Teatro de San Miguel Cajonos) vendrían a corroborar tal afirmación, pues inevitablemente se les consideraría como parte del teatro comunitario, es decir, dentro de una gama enormemente amplia y diversa de grupos cuyo único signo distintivo es el de ser un teatro popular, universitario, campesino o indígena. Pero si se delimita el teatro comunitario a aquellas experiencias que deliberadamente se inscriben en esta asociación civil o que se autodefinen como tal, se concederá que en éstas impera en general una realización no feliz de la fiesta. Si se parte del principio que cualquier experiencia teatral puede ser considerada como teatro comunitario, no se llega demasiado lejos porque entonces ninguna lo es verdaderamente. La descripción y la interpretación que a continuación expongo concierne los encuentros que convoca la asociación de teatro comunitario y no el conjunto del teatro popular, universitario, rural, indígena o campesino.

En segundo lugar, cabe precisar el cuadro interpretativo. Cuando se trata de interrogar la realización feliz o no feliz de la fiesta se corre el riesgo de proyectar la fiesta anhelada sobre la fiesta vivida, la noción que se tiene de antemano sobre lo observado. La dificultad se hace mas grande todavía al no poder recurrir a una definición que pueda aplicarse a todos los casos. No disponemos en efecto de una teoría unificada o una concepción con validez general. Ante esta dificultad, las interpretaciones antropológicas y sociológicas de la fiesta buscan salir ya sea por la puerta del universalismo o bien por la del relativismo. La primera encuentra en la obra de Callois ${ }^{5}$ los fundamentos para postular una universalidad de la fiesta, independientemente de los aspectos que pueda adquirir en contextos locales. La concepción de Caillois, de algún modo dominante en los estudios de la fiesta, enfatiza los aspectos de exuberancia, exceso, dilapidación, alegría suprema, desorden y subversión que se supone están presentes en toda fiesta. Según esta concepción, habría que restringir este término a aquellas acciones "que comprometen a la sociedad entera, y que implican una efervescencia, una exaltación que se consume en gritos y gestos, que incitan
Véase Elizabeth Araiza Hernández, Sous le signe de "l'entre deux » Anthropologie du théâtre amérindien au Mexique, Tesis de Doctorado, Universidad de París 8, 2003.

4

Una fiesta feliz es lo que Isambert llama una «fiesta lograda (une fête réussie), una institución generadora de espontaneidad» (François-André Isambert, Le sens su sacré. Fête et religion populaire, París, Editions du Minuit, 1982, pág. 157). Si se adopta el concepto "eficacia simbólica» de Lévi-Strauss podría decirse que una fiesta feliz es aquella que cumple esta función de «inducir una transformación», a través de una atribución de sentido, de una estructura (la narración mítica) hacia otra (la cura chamánica) (Claude LéviStrauss, Anthropologie structurale, París, Plon-Pocket, 1974, pág. 231). El problema es que, en la perspectiva levistrausiana, esta arribución de sentido opera a nivel de la expresión verbal, pues se funda necesariamente en un mito o un tema conocido por todos. Para otros autores en cambio, ésta opera a nivel de la acción misma. Las acciones significan por el hecho de $y$ en el momento mismo de ser realizadas. En ciertos contextos rituales y festivos, incluso las palabras ejercen esta función performativa $\circ$ realizativa (significan algo por el hecho de ser proferidas). La felicidad proviene de la evaluación que se hace al desempeño de la fiesta. Pero esta "evaluación no se hace en función de su validez, sino en términos de su adecuación y relevancia institucional o cultural; la evaluación descansa en la "felicidad» o «infelicidad» de su realización, en el sentido propuesto por Austin» (Rodrigo Díaz Cruz, Archipiélagos de rituales, teorías antropológicas del rifual, Barcelona, Anthropos, 1998, pág. 226).

5

Roger, Caillois, L'homme et le sacré, París, Gallimard, 1976.

La fiesta verdadera: juna realización feliz en el teatro? Luces y sombras de los encuentros de teatro comunitario en México ELIZABETH ARAIZA HERNÁNDEZ 


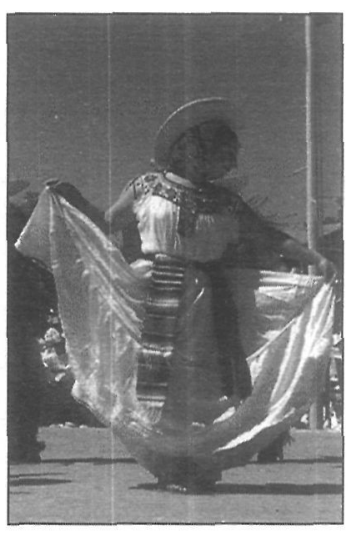

Muchacha en un Baile de rubios de Juxtlahuaca.

6

Citado por Marlène Albert-Llorca, «Regards anthropologiques sur la fête», Parcours, les cahiers du GREP-MP, 2001-2002, núm. 25/26 (www.grep-mp.org) pág. 2.

7

Isambert, op. cit., págs. 125163.

La fiesta verdadera: ¡una realización feliz en el teatro? Luces y sombras de los encuentros de teatro comunitario en México

ELIZABETH

ARAIZA HERNÁNDEZ a un abandono sin control hacia los impulsos mas irreflexivos, a la dilapidación y a la destrucción de las riquezas acumuladas gracias al trabajo cotidiano, al exceso de comida, de bebidas, de ruidos, de sexualidad y de violencia» ${ }^{6}$ Si la prohibición, alimenticia, sexual, social o política, que pesa en lo cotidiano queda suspendida en la fiesta, es con objeto de que se cumpla la función primordial de ésta, que es la de restaurar el desorden original, de tal modo que la naturaleza y la sociedad puedan así ser regeneradas. Se puede apreciar cómo esta concepción conduce hacia el precipicio del universalismo, desde el momento en que erige como modelo un tipo de fiesta.

La crítica que algunos autores han hecho a esta visión universalista reveló la existencia de acciones que, aunque comprometan a la sociedad entera, no ostentan estos aspectos, sino más bien un carácter solemne, recatado, no-excesivo, y ordenado. Es decir, que hay otros modelos posibles de fiesta y que no hay razón de erigir uno de ellos como el bastón de medida. Esta postura sin embargo condujo a otro precipicio: el del relativismo. Ahora bien, el inconveniente de éste es que impide determinar qué es una fiesta ante la imposibilidad de comparar una con otra. Al final de cuentas todas son igualmente válidas, resulta imposible construir un juicio crítico.

A este respecto, parto del principio que se puede hacer una interpretación de los encuentros de Teatro Comunitario en términos de fiesta, sin que se tenga que recurrir a este concepto dominante inspirado por Caillois y $\sin$ que se tenga que incurrir en una postura relativista. Para evitar una proyección de la fiesta anhelada sobre la vivida, de la fiesta primitiva sobre la real, para no caer en la posición según la cual resulta imposible juzgar el carácter feliz o no feliz de la fiesta, se tiene que partir de un criterio mínimo de identificación. Según mi modo de ver, la clave para superar esta dificultad de proyección se encuentra en la lectura sociológica que hace Isambert, expuesta en los capítulos 1 y 2 de la segunda parte intitulada, «La fiesta» .

Por último, es necesario precisar que la interpretación que aquí presento se apoya en un trabajo de observación directa llevado a cabo durante varios años (1992-2000), en diversos poblados, en varias situaciones de representación y en numerosas conversaciones con las personas que participan en estos eventos: organizadores, actores, espectadores y habitantes de las comunidades en donde se lleva a cabo.

\section{LAS FIESTAS DE TEATRO COMUNI- TARIO}

La convergencia principal de los grupos que integran la asociación de teatro comunitario sucede una vez por año. Los primeros nueve encuentros fueron convocados bajo el título sugestivo de Fiesta Regional o bien Fiesta Nacional, según el caso. Más recientemente, las convocatorias a nivel regional adoptan el apelativo de «festival», o simplemente de «Encuentro de Teatro Comunitario». Aunque tienda a abandonarse el término, estos encuentros reproducen el mismo esquema general de las primeras Fiestas. Las primeras Fiestas Regionales estaban regidas por un principio según el cual la Fiesta Nacional debería constituir algo así como un crisol representativo de las obras teatrales mejor logradas a nivel regional. A partir de un proceso de selección, se determinaba cual de los grupos que nacen y trabajan en la región concernida merecía acudir a la fiesta nacional como digno representante de la misma. Sin embargo, con el paso del tiempo este principio se ha ido modificando. La lógica que rige la participación de los grupos, tanto a nivel regional como nacional, suele ser menos clara hoy en día. El criterio más evidente es la integración de los grupos y de las personas invitadas a la fiesta o el encuentro en una red de relaciones interpersonales e interinstitucionales. Con más frecuencia, estos encuentros se asemejan a una confluencia fortuita, circunstancial, de personas con motivaciones diversas, con proyectos variados, tanto profesionales como de vida.

A las fiestas de teatro comunitario asisten artistas proveniente de diferentes sectores de la sociedad mexicana: indígenas, campesinos, estudiantes, obreros, amas de casa. Tanto miembros de las clases populares y medias como altas, ya sea rurales o urbanas. Asisten actores de distintas edades (niños, adolescentes, jóvenes, adultos y ancianos) y sexos (masculino y femenino), cuya actividad se despliega en una asombrosa diversidad de medios: teatro profesional, teatro universitario, casa de la cultura, iglesia, barrios, calle (como el teatro de los niños de la calle o los «chavos banda»). En las fiestas del teatro comunitario se presentan tanto obras teatrales del repertorio universal como creaciones originales; obras interpretadas por artistas profesionales o por «amateurs». Se presentan también danzas y rituales indígenas, «performances» posmodernos y teatro de marionetas o de guiñol al lado de «las obras de la iglesia», y prácticas de 
curación al lado de representaciones relativas a la vida cotidiana en el medio rural o en el urbano, tanto indígena como mestizo.

Ante esta gama asombrosamente amplia y diversa de grupos y producciones teatrales, siempre surge la sospecha de qué es lo que los puede unificar. Se impone por sí misma la pregunta de en qué medida hay una coherencia en todo esto. Por ejemplo, en qué medida no se trata simplemente de un festival de teatro, que se distingue apenas en algún aspecto de aquellos que no son del teatro comunitario. Una serie de acciones y sobre todo un discurso enfático del sentido que debe atribuirse a esas acciones van a establecer la diferencia respecto a un festival teatral cualquiera. Como podrá apreciarse, estas acciones y estos discursos defienden implícitamente una concepción de fiesta, similar a la de Caillois. En el fondo, la fiesta anhelada por los miembros de la asociación de teatro comunitario corresponde con la vivida en el medio indígena. Esta a su vez es asimilada de facto con la idea de «fiesta primitiva» según la fórmula de Callois.

Aunque suelan llevarse a cabo durante el período de vacaciones de verano (entre junio y septiembre), estas fiestas no disponen de una fecha fija. Por regla general, no disponen tampoco de un lugar fijo, pues el pueblo o la ciudad en que se celebran cambia cada vez. La Fiesta regional dura en promedio tres días, en tanto que la nacional suele abarcar entre cinco y seis días. La regional suele llevarse a cabo en pueblos pequeños, en tanto que la nacional se realiza en la capital del estado o bien en la cabecera municipal o en la ciudad más importante de la región concernida. El grupo teatral que habita y trabaja en ese lugar se propone y, de ser aceptado, asume las tareas organizativas de la Fiesta. Si bien el programa de actividades es singular en cada encuentro, se puede identificar algo como una trama general presente en todos ellos.

\section{LAS TRES FASES CONSTITUTIIVAS DEL ENCUENTRO DE TEATRO CO- MUNITARIO}

Estos encuentros presentan por lo general tres fases: una fase propiamente teatral, que se realiza cada día por la tarde durante el tiempo que dura la fiesta; una festiva, que marca el inicio y la clausura del evento, y una última que puede ser caracterizada como de organización, de redefinición y de promoción que se lleva a cabo cada día por las mañanas.
Son estas dos últimas las que marcarían una diferencia respecto de cualquier festival de teatro.

La fase teatral se realiza al modo de los festivales: se presentan entre tres y cinco obras teatrales, precediendo cada una un discurso de presentación por parte de un maestro de ceremonias. Incluso la construcción del espacio teatral reproduce la lógica de delimitación y de separación de los teatros de sala. Aunque se realice al aire libre, los límites entre el espacio del público y el espacio de los actores, así como entre un adentro y un afuera del evento teatral, quedan bien delimitados. Con frecuencia se hace uso de límites materiales pero también de una línea imaginaria.

La segunda fase queda marcada por la realización de talleres en los que, por lo general, se hacen ejercicios de expresión teatral o de improvisación, aunque también se hacen trabajos de pintura, escultura, decoración, construcción y manipulación de marionetas. Más que responder a un proyecto o a un programa preconcebidos, estas actividades suelen organizarse en el momento mismo aprovechando los recursos humanos y materiales con los que se cuenta en cada fiesta, de tal modo que los contenidos de esta fase resultan ser siempre singulares. En esta fase suelen realizarse reuniones o asambleas, seminarios o coloquios (con la participación de investigadores universitarios), en donde se redefinen las instancias organizativas del próximo encuentro, se eligen o reeligen los representantes de la asociación, se incluyen nuevos miembros, se establecen compromisos, se elaboran nuevos proyectos y se discuten los métodos de trabajo teatral. Es el momento en que se evalúan las acciones anteriores y se proyecta el futuro del teatro comunitario. Para los representantes de la asociación este momento constituye una suerte de hito, un lugar propicio para hacer visible el rol social y el estatuto que cada quien ocupa en la estructura del teatro comunitario.

Las acciones que marcan el inicio y la clausura del encuentro teatral pueden ser consideradas como la tercera fase. Aunque se realicen en tiempos diferentes presentan prácticamente las mismas características, lo cual autoriza a considerarlas como una sola fase. La clausura se distingue, sin embargo, por la entrega solemne de constancias de asistencia a los actores y de agradecimiento a las personas que ocupan un rango institucional. El primer día por la tarde, suele realizarse un desfile que parte de las afueras del pueblo

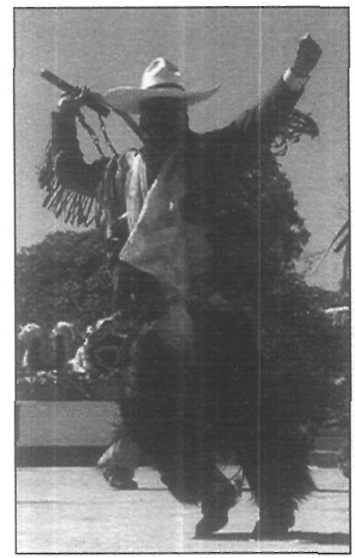

Muchacho en un Baile de rubios de Juxtlahuaca.
La fiesta verdadera: ¿una realización feliz en el teatro? Luces y sombras de los encuentros de teatro comunitario en México ELIZABETH ARAIZA HERNÁNDEZ 


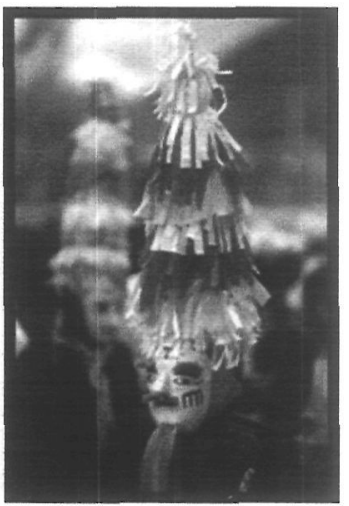

Danzante de Zitlala. y culmina en el espacio teatral, situado éste por lo regular en la plaza central, el zócalo o centro. Se invita a las autoridades del pueblo o de la ciudad para abrir el cortejo, la banda de música local imprime bullicio y alegría a los contingentes que le siguen, conformados éstos por todos los actores que avanzan alegremente llevando sus respectivos vestuarios. En ocasiones, se suman al cortejo grupos de danzantes locales, ejecutando con brío danzas tradicionales. El bullicio y la alegría se hacen aún más patentes con los fuegos artificiales que aporta en ocasiones la comunidad, así como los objetos vistosos que simbolizan la fiesta local. Por ejemplo, en Oaxaca, grandes $\mathrm{y}$ vistosas marmotas suntuosamente adornadas acompañaron el desfile de la fiesta nacional de teatro comunitario. Numerosos grupos de danzantes con su vestuario multicolor ejecutaron impresionantes pasos con lo que lograron imprimir a la fiesta regional de Juxtlahuaca un tono y una forma singulares. En Yucatán, estos encuentros suelen inaugurarse con la ejecución de la jarana, incluyendo tanto el suntuoso vestuario de los danzantes como los estandartes y demás símbolos de esta tradición maya-yucateca. Suele integrarse igualmente alguno de los rituales característicos del lugar donde se realiza la fiesta. En Zitlala, Guerrero, el programa teatral fue precedido por una ceremonia de limpia a los participantes, realizada por un curandero local. En San Juan Tabàa, el conjunto de visitantes (actores, miembros asociados, representantes de instituciones de gobierno) llevaron a cabo acciones muy solemnes para ritualizar la petición ante el consejo de ancianos de realizar el encuentro teatral en ese pueblo.

Para envolver este encuentro teatral con un manto de fiesta, se incurre, sobre todo durante la tercera fase, en una apropiación de los signos locales. Pero no se trata de incluir cualquier signo por el hecho de ser festivo, sino que se eligen aquellos que simbolizan la fiesta «verdadera», la fiesta bien lograda, es decir la fiesta patronal, que por ende es la indígena. $\mathrm{Si}$ estos encuentros se realizan en regiones caracterizadas por un alto índice de población indígena, no es tanto porque los indígenas constituyan una mayoría en la asociación o en los encuentros, sino porque aparecen, en la óptica de los promotores teatrales, como la norma de la festividad. Todo sucede como si el medio indígena comportara por sí mismo esta esencia festiva, y que bastara con realizar ahí las actividades teatrales para que ellas adquirieran este halo de festividad verdadera.
Es como si los objetos que se encuentran ahí estuvieran en sí mismos cargados de una ritualidad, de una sacralidad y de una festividad esenciales, como si fuera suficiente estar ahí para lograr un acceso inmediato.

Con todo, ha habido fiestas de teatro comunitario que, aunque se lleven a cabo en el medio indígena, se desenvuelven en un ambiente no sólo solemne sino incluso triste, no sólo sobrio sino monótono. Un ambiente más cercano a la indiferencia y a la apatía que emana por igual de los actores, de los espectadores y de los lugareños. Pero también ha habido fiestas que aunque se realicen en poblados mestizos o urbanos vieron materializar este ideal de fiesta verdadera, «la fiesta primitiva». Éstas se caracterizaron por una cierta exuberancia, una alegría desbordada, un despilfarro de energía expresada en gestos y movimientos, una ostentación de símbolos auditivos, sensoriales, gustativos. Lo cual indica que en los encuentros de teatro comunitario la fiesta no siempre se logra bien. $O$ si se quiere, no siempre hay un logro feliz y eficaz de la concepción de fiesta en tanto que exuberancia, exceso de toda suerte, subversión del orden establecido, desorden exacerbado, alegría y bullicio estridentes. Porque se puede argumentar, en favor de éstos, que existen otros modelos de fiesta.

Si se apela al concepto de fiesta en su sentido solemne, de orden y de control, se concluirá sin duda que sí hay aquí una realización feliz de la misma. Podría decirse que estos encuentros pueden suscitar tanto este modelo como aquel de exuberancia, desorden y exceso. Incluso se pueden traer a colación datos etnográficos que ponen de manifiesto la existencia de fiestas indígenas que no presentan las características de la fiesta primitiva. Baste evocar, como prueba, la discreción, la solemnidad, la lentitud que suelen adquirir los bailes (expresión espontánea de la alegría en pareja siguiendo el ritmo de la música) e incluso la danza (grupos organizados expresamente). A menudo, éstos dan la impresión de que no «pasa de ser un digno frotar de los pies en el suelo, [una ausencia de] pasos brillantes». Esta perturbadora impresión se disipa tan pronto como se repara en la preocupación esencial que motiva tanto al danzante como a los espectadores miembros de la comunidad indígena: las obligaciones sagradas de los ejecutantes. Comprendemos entonces que: «la falta de pasos brillantes sólo sirve para subrayar que es el simple acto de la ejecución lo que designa a alguien como poseedor de 
una posición poderosa, junto con el atavío del danzante y los objetos que éste empuña durante la danza» ${ }^{8}$.

Lo anterior autorizaría a afirmar que los encuentros que se desenvuelven según el modelo ordenado no contradicen, sino que reafirman, ese ideal de fiesta indígena del teatro comunitario. También podría subrayarse la función de algunas fiestas de instaurar un estatuto social, de comunicar el lugar que cada quién ocupa en la jerarquía social, es decir, de preservar un orden social. Así se enfatiza al mismo tiempo la existencia de este tipo de fiestas en el medio indígena. El riesgo de este razonamiento es que conduce a un relativismo conformista incapaz de ejercer una reflexión crítica. En consecuencia, habría que reparar en un aspecto importante de la fiesta, independientemente del modelo bajo el cual se desenvuelva, el que atañe a la sociedad entera. Estos encuentros, en cambio, siguen concerniendo a un grupo reducido de personas, a lo sumo el conjunto de los visitantes, más comúnmente a los representantes de esta asociación teatral. Si de instaurar un orden se trata, es el de la asociación, mas no el de todos los participantes. Ahora bien, no se trata aquí tanto de determinar qué tipo de fiesta realiza el teatro comunitario como de averiguar por qué el concepto de fiesta que éste transmite no siempre se realiza felizmente. ¿A qué se debe que, a pesar de los esfuerzos de los organizadores de tejer un ropaje de fiesta con el cual envolver estos encuentros, los espectadores locales se queden seguido con la impresión de ser simples testigos, de asistir a una especie de acto obligado, ajeno, impuesto desde afuera y desde arriba? La expresión que usan a veces los zapotecos de Oaxaca para referirse a la fiesta de teatro comunitario, resulta bastante reveladora a este respecto: "la fiesta del gobierno", a la cual oponen la «costumbre», es decir, la fiesta patronal, la indígena.

¿En qué medida dicha variación puede atribuirse exclusivamente a uno o a un conjunto de factores? Se pueden dar varios tipos de situaciones determinantes, como la capacidad de construir una amplia red de relaciones interpersonales e interinstitucionales por parte de los miembros de esta asociación teatral, o bien el arraigo de la actividad teatral en el pueblo donde se lleva a cabo la fiesta de teatro; incluso el grado de simpatía y de reconocimiento de que gozan el grupo teatral y los actores en la población que acoge el encuentro. El tamaño del pueblo puede asimismo incidir: las comunidades con población reducida serían, tal vez, más propicias a la convivencia y a la reciprocidad entre visitantes y lugareños. En consecuencia, podría decirse que la Fiesta regional es más propicia para la festividad que la nacional. Puede ser que se trate simplemente del grado de elaboración de las obras teatrales y de los espectáculos que se presentan a lo largo de la fiesta. A mayor calidad de las producciones teatrales correspondería una respuesta más entusiasta y más participativa de parte de los espectadores. Se puede atribuir al temperamento diferenciado de los lugareños: los mestizos o los campesinos serían, quizá, más dados a la espontaneidad y a la participación activa y directa, mientras que los indígenas serían más reservados, discretos y reacios al contacto con los visitantes. Se trata tal vez, de un proceso involutivo según en cual las fiestas más recientes serían menos festivas que las primeras. O bien, al contrario, de un proceso evolutivo, hacia una festividad cada vez mejor lograda.

Según mi modo de ver, la definición que sugiere Isambert resulta suficientemente restringida como para no sucumbir a la tentación relativista, pero también suficientemente abierta como para no erigirla en modelo, cediendo al universalismo. Se presenta entonces como un argumento convincente para responder a las interrogantes arriba planteadas. Para Isambert una fiesta es:

...primero que nada un acto colectivo. La fiesta se rodea de representaciones, de imágenes materiales o mentales, pero éstas no figuran sino como acompañantes del elemento activo. Se diría lo mismo de los diversos objetos materiales, decoración, alimentos, etc. que sirven para la acción de la fiesta. En segundo lugar, la fiesta es total o por lo menos completa, pues pone en juego varios registros de la vida social. En esto, la noción de fiesta, desborda, la noción de rito e incluso la de ceremonia, secuencia de ritos. Por último, esta acción es simbólica, en el sentido de que evoca un ser, una colectividad...La acción propia de la fiesta es la simbolización [...]; para que el símbolo sea reconocible tiene que ser relativamente fijo?.

Lo anterior me conduce a sostener que es justamente la ausencia de una fecha fija y de un lugar fijo lo que produce una variabilidad en los encuentros de teatro comunitario. De alguna manera, el mayor éxito de estas fiestas es al mismo tiempo su mayor fracaso, a saber, la movilidad espacial y temporal. La ausencia de una fecha fija y de un lugar fijo impide que se cumpla esta condición de simbolización

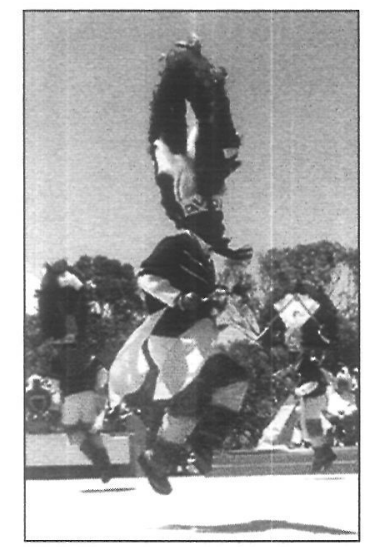

Danza de la pluma. Oaxaca.

8

David Freidel et al., El cosmos maya. Tres mil años por la senda de los chamanes, México, FCE, 1999, pág. 267.

9 Isambert, op. cit., págs. 160161.

La fiesta verdadera: ¿una realización feliz en el teatro? Luces y sombras de los encuentros de teatro comunitario en México ELIZABETH ARAIZA HERNÁNDEZ 
11

Ibid., pág. 35 .

12

Goffman citado por Clifford Geertz en La inferpretación de las culturas, Barcelona, Gedisa, 1989 , pág. 348.
La fiesta verdadera: ¿una realización feliz en el teatro? Luces y sombras de los encuentros de teatro comunitario en México

ELIZABETH

ARAIZA HERNÁNDEZ que es constitutiva de toda fiesta. Subrayar la necesidad de una relativa estabilidad de los símbolos para que puedan simbolizar no implica prejuzgar la validez de sus contenidos, de su carácter ordenado o desordenado, subversivo o preservador del orden establecido, alocado o sosegado, exuberante o sobrio.

Las estrategias de la asociación de teatro comunitario para hacer de los encuentros una fiesta verdadera, consistentes por ejemplo en la adopción de un rebozo, o en la recreación de la calenda, pueden cobrar un sentido de ritualidad y de festividad en un pueblo de la sierra, pero no en uno de la costa. El rebozo no se usa en la costa y la calenda no es tradición ahí. Este tipo de estrategias apuntan a la imposición de un modelo que se supone tendría que funcionar de igual manera en cada pueblo. Ahora bien, el comportamiento festivo no se decreta. No hay cosa, persona, lugar que sea por esencia sagrado, festivo o ritual, pero cualquier elemento de la naturaleza, lugar, persona o cosa pueden devenir sagrados. Para que esto suceda, se necesita una practica habitual, una continuidad, una relativa estabilidad de los símbolos. Es a través del uso que un signo adquiere un contenido sagrado. La ritualidad en la fiesta «no es una cosa, sino una relación de los hombres con las cosas y con las personas» ${ }^{10}$. Ningún grupo social posee la capacidad exclusiva de suscitar un comportamiento festivo.

La actividad teatral puede suscitar un ambiente festivo tanto en una comunidad indígena como en un pueblo mestizo, en un barrio pobre de la ciudad como en una colonia clase media. Para que esto suceda, para que la fiesta de teatro se vuelva una celebración colectiva, que concierna a todos por igual, tanto a los habitantes de la comunidad donde se realiza como a los organizadores y a los actores, se necesita una práctica habitual, se requiere que los símbolos que ésta intenta instituir gocen de una relativa fijación. Como nos hace ver Gruau a partir de un comentario de Paul Claudel: «Rien n'est sacré que ce que nous consacrons, que ce que nous sacralisons» ${ }^{11}$. Se podría decir que los encuentros de teatro comunitario andan en busca de un lenguaje; en esto reside su ineficacia relativa, porque la estabilidad de tal lenguaje implica compartir un modo de vida, en este caso la de los habitantes de las comunidades en donde éstos se llevan a cabo. Pero, dado que la sede de la fiesta cambia todo el tiempo, que no hay una fecha precisa y que los símbolos no son compartidos por todos, no se cumple esta condición.
La participación más o menos asidua permite a un grupo reducido de gente de teatro y de promotores teatrales atribuir un sentido a cada una de las acciones, a cada uno de los objetos, a cada uno de los discursos constitutivos de la fiesta. De tal modo, estos encuentros establecen, sin proponérselo tal vez, una distinción entre un grupo reducido que logra alcanzar una visión de continuidad y otro mucho más numeroso para quien esta visión no puede ser sino discontinua. Esta visión de discontinuidad les impide compartir el mismo sentido de fiesta, de celebración. La mayoría de los asistentes se queda con la impresión de asistir como testigos o invitados a lo que ese grupo reducido celebra, instaura, ordena, sacraliza o bien desordena, subvierte, despilfarra y critica. Para que la fiesta de teatro comunitario deje de ser percibida por la mayoría de asistentes como un proceso discontinuo, un acto particular que sólo se vive una sola vez, algo que viene de fuera, que es externo a la comunidad e incluso ajeno, se necesita no sólo la capacidad organizativa de los promotores, la calidad estética de la propuesta teatral o la cantidad de grupos, se requiere un arraigo, una cierta estabilidad de los símbolos.

Si los encuentros de teatro comunitario logran en ocasiones realizar una fiesta feliz, a pesar de la ausencia de una fijeza de los símbolos, se debe precisamente a su carácter situacional. Esto se hace posible cuando la actividad teatral adopta la dinámica social y cultural del lugar en donde se realiza. Cuando el conjunto de las personas que se encuentran están en disposición de entregarse por completo a esta misma actividad, sin tener otra razón, sin querer imponer un modelo de fiesta, sino dejarse llevar por ese flujo común que emerge de la situación. Para abreviar, es cuando esos encuentros son simplemente una «reunión focalizada», es decir,

...un conjunto de personas entregadas a un flujo común de actividad y relacionadas entre sí en razón de ese flujo [...] Esas reuniones se forman y se dispersan; sus participantes fluctúan; la actividad que los concentra es un proceso singular, particular, que se repite de cuando en cuando en lugar de ser un proceso continuo. Dichas reuniones toman su forma de la situación que las suscita, del suelo en que están situadas $^{12}$.

Se puede apreciar la dificultad que enfrentan los grupos teatrales en su lucha por cautivar la atención de un público masivo y 
diverso. La dificultad es mayor todavía para aquellos que decidieron abandonar el lugar, de alguna manera, confortable de la sala con su público cautivo y fiel aunque reducido en cantidad. Es esta la luz a que refiere el título del presente artículo. Salir a la calle, presentarse al aire libre, adentrarse en pueblos poco habituados al teatro, exige un trabajo de experimentación constante con tal de encontrar los modos de organzación social, de creación y de difusión acordes a cada uno de los grupos sociales que se pasean por las calles o al aire libre y que habitan en los pueblos. Veamos ahora las sombras. El dilema del teatro comuntario parece ser el siguiente : asumir que los encuentros a los que convoca son una reunión focalizada, esto es, una cuya realización es fortuita y circunstancial, pero feliz, o bien seguir insistiendo en imponer el modelo de la fiesta indígena, aunque su realización resulte casi siempre poco feliz. Podemos admitir que el teatro es una práctica universal, pero hay que reconocer que los modos en que se ésta instituye, varian de una sociedad a otra, de un pueblo a otro, de una cultura a otra.

\section{BIBLIOGRAFÍA}

Araiza Hernández, Elizabeth, Sous le signe de "l'entre deux» Anthropologie du théâtre amérindien au Mexique, tesis de doctorado, Universidad de París 8, 2003.

Albert-Llorca, Marlène, «Regards anthropologiques sur la fête», Parcours, les ca- hiers du GREP-MP, 2001-2002, $N^{\circ}$ 25/26, (www.grep-mp.org).

Caillois, Roger, L'homme et le sacré, París, Gallimard, 1976.

Díaz Cruz, Rodrigo, Archipiélagos de rituales, teorías antropológicas del ritual, Barcelona, Anthropos, 1998.

Freidel, David, Schele, Linda, y Parker, Joy, El cosmos maya. Tres mil años por la senda de los chamanes, México, Fondo de Cultura Económica, 1999.

Frischman, Donald, El nuevo teatro popular en México, México, CITRU-INBA, 1990.

Geertz, Clifford, La interpretación de las culturas, Barcelona, Gedisa, 1989.

Grimes, Ronald L., Simbolo y conquista. Rituales y teatro en Santa Fé, Nuevo México, México, Fondo de Cultura Económica, 1981.

Gouhier, Henri, L'essence du théâtre, París, Aubier-Montaigne, "Présence et pensée», núm. 11, 1968.

Gruau, Maurice, L’bomme rituel, París, Métailié, 1999.

Isambert, François-André, Le sens su sacré. Fête et religion populaire, París, Editions du Minuit, 1982.

Lévi-Strauss, Claude, Anthropologie structurale, París, Plon-Pocket, 1974.

Rosales Ayala, Héctor, Tlaltenango: las transformaciones del sentido de una fiesta popular, México, UNAM-CRIM, 1988.

Versényi, Adam, El teatro en América Latina, Nueva York, Cambridge University Press, 1996.
Ia fiesta verdadera: juna reali-

zación feliz en el teatro? Luces y sombras de los encuentros de teatro comunitario en México

ELIZABETH

ARAIZA HERNANDEZ 


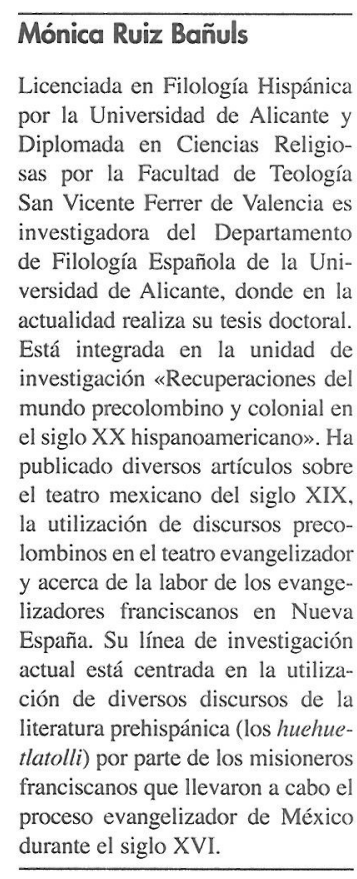

Licenciada en Filología Hispánica por la Universidad de Alicante y San Vicente Ferrer de Valencia es investigadora del Departamento de Filología Española de la Universidad de Alicante, donde en la actualidad realiza su tesis doctoral. Está integrada en la unidad de investigación «Recuperaciones de mundo precolombino y colonial en el siglo XX hispanoamericano». Ha publicado diversos artículos sobre el teatro mexicano del siglo XIX, la utilización de discursos precolombinos en el teatro evangelizador y acerca de la labor de los evangelizadores franciscanos en Nueva España. Su línea de investigación ción de diversos discursos de la literatura prehispánica (los huehuetlatolli) por parte de los misioneros franciscanos que llevaron a cabo el durante el siglo XVI.

\section{LA DEVOCIÓN POPULAR GUADALUPANA EN LA TEATRALIDAD MEXICANA}

MÓNICA RUIZ BAÑULS

\section{RESUMEN}

La irrupción del hecho guadalupano en diversas manifestaciones dramáticas a lo largo del acontecer histórico de México responde sin duda al hecho de que la teatralidad popular ha expresado siempre las luchas, tribulaciones y preocupaciones que han ido marcando el ritmo de las vivencias cotidianas e históricas de un pueblo.

En este sentido, la devoción a la Virgen de Guadalupe, patrona de México y símbolo de mexicanidad, se convierte en una manifestación de la identidad colectiva del pueblo, que no se limitará sólo a lo religioso sino que, como veremos en este trabajo, abarcará una dimensión social, ideológica y cultural que ha motivado durante siglos y, lo sigue haciendo en la actualidad, su notable presencia en las representaciones teatrales populares.

\section{POPULAR GUADALUPE DEVOTION IN MEXICAN HISTRIONICS}

\section{ABSTRACT}

The appearance of the Guadalupe event in many dramatic representations throughout bistoric occurrence in Mexico undoubtedly responds to the fact that popular drama has always expressed the struggles, tribulations and preoccupations which have set the rbythm of everyday and historical events within a village.

In this sense, the devotion to the Virgin of Guadalupe, patron saint of Mexico and symbol of what it means to be Mexican, becomes a show of people's collective identity. This work demonstrates that this is not limited to the merely religious but also, includes a social, ideological and cultural dimension which for centuries has made and continues to make its notable presence felt in popular dramatic representations.

El teatro como objetivización sensible de unas creencias ancestrales, como encarnación del misterio de las cosas y la trascendencia de las conductas ha funcionado desde sus orígenes como un conjunto escénico en el que la historia humana y percepción de lo divino se han unido como expresión eficaz de un intercambio festi- vo. En este sentido, las manifestaciones teatrales que surgen en torno a la Virgen de Guadalupe, patrona de México y, sobre todo, símbolo de mexicanidad, encarnan perfectamente dicha simbiosis en la que estas representaciones se convierten en modos de expresión definidores de la identidad del pueblo mexicano.
La devoción popular guadalupana en la teatralidad mexicana MÓNICA RUIZ BAÑULS 
Desde este planteamiento, quiero acercarme en el presente trabajo al teatro guadalupano no desde la exhaustividad de análisis de un cuerpo documental ${ }^{1}$, sino desde la necesaria vinculación de estas manifestaciones a un marco de referencia más amplio relativamente poco estudiado: el de la religiosidad popular. Considero que la arraigada devoción a la Virgen de Guadalupe en México representa uno los puntos clave de dicha teatralidad: aquel que revelan las manifestaciones dramáticas guadalupanas como una forma de entender el mundo dentro de los contextos sociales y políticos en los que se han visto inmersas.

\section{DEL TEATRO EVANGELIZADOR AL TEATRO GUADALUPANO}

A finales del siglo XVI y, sin duda, estrechamente vinculadas a la institucionalización del culto guadalupano entre la población indígena, surgen una serie de piezas dramáticas relacionadas con la Virgen de Guadalupe 2 que pueden ser consideradas como la evolución de un teatro evangelizador que, tras su manifiesto declive en esta época ${ }^{3}$, continuó desarrollándose en el ámbito popular indígena. En dicho contexto, este teatro fue absorbido y transformado para «terminar disolviéndose en sustancia folklórica, forma en que ha sobrevivido hasta nuestros días" ${ }^{4}$, de manera que estas manifestaciones aún hoy se pueden encontrar en muchas partes de México donde el ciclo navideño se inicia con alguna dramatización, más o menos extensa, de la aparición de la Virgen, con brevísimas pantomimas de Guadalupe revelándose al humilde indio Juan Diego o con representaciones completas de obras clásicas del teatro popular como Las Cuatro Apariciones de Nuestra Señora de Guadalupes.

Ahora bien, considero que se hace necesario plantear brevemente el proceso histórico que da origen al guadalupanismo mexicano y que contribuirá sin duda a la mayor comprensión de la vigencia de esta temática en la teatralidad popular. Parto para ello de la reflexión de Edmundo O'Gorman', quien plantea que la devoción guadalupana nace como fruto de los intereses personales de fray Alonso de Montúfar y del vigoroso empeño de este arzobispo por «remozar con aquella nueva imagen el viejo culto de substitución de la diosa Tonatzin» ${ }^{\top}$. Para este investigador, la extraña intervención de Montúfar en el hecho guadalupano y el apoyo incondicional del prelado hacia la imagen del Tepeyac res-

ponderían a un proyecto político y religioso muy concreto:

El objetivo de la corona española al enviar al teólogo dominico para ocupar la sede vacante de la diócesis de México era asentar con firmeza la autoridad episcopal y regalista de la Iglesia española que propugnaba por la estricta observancia de la

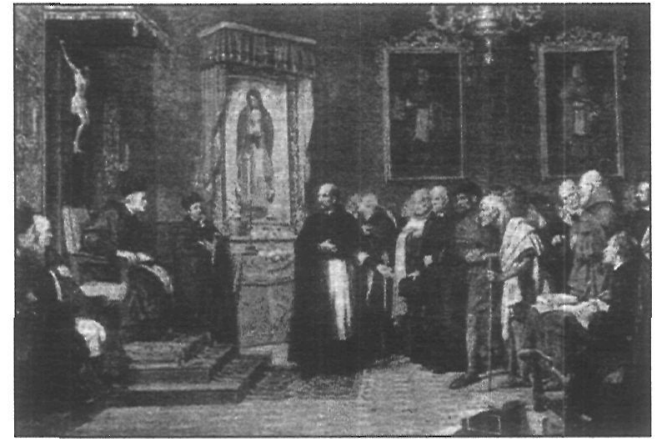

Informaciones de 1666. Cuadro José María Ibarrán. Piniado en 1873 para la Colegiata de Guadalupe.

legislación canónica; el mantenimiento del aparato ceremonial y ritual y el respeto a las tradiciones y costumbres de la devoción popular. Tal, pues, en términos muy generales es el programa con el que debía cumplir el señor Montúfar: el favor que le dispensó a la imagen de Tepeyac se explicaría en función de esa suprema finalidads.

Todo este proceso es abordado por O'Gorman a través del estudio de la Información que el Señor Arzobispo de México D. Fray Alonso de Montúfar mandó practicar sobre un sermón que el 8 de septiembre de 1556 predicó fray Francisco de Bustamante acerca del culto de nuestra señora de Guadalupe", donde se recoge la temprana polémica en torno a la validez del culto guadalupano. Fue con motivo de la celebración de la Natividad de María de 1556 cuando el reconocido predicador franciscano Francisco de Bustamante puso de manifiesto durante el sermón lo dañino del culto a la Virgen de Guadalupe, argumentando que "había sido inventada ayer» y que la imagen «había sido pintada por un

1

Existen diversas investigaciones que abordan este tema con detalle pero, sin duda, el trabajo de lectura casi obligada en este sentido sigue siendo el de Armando de María y Campos, La Virgen frente a las candilejas o El teatro guadalupano, México, Ediciones Populares, 1954

2

Estoy pensando por ejemplo en textos como El coloquio de la Aparición, La conquista espiritual de la América por María Santísima de Guadalupe o El Portento Mexicano (cf. los datos aportados por
Fernando Horcasitas en «Las piezas teatrales en lengua náhuatl. Bibliografía descriptivas, Boletín Bibliográfico de Antropología (México), 1948, núm. XI, págs. 155-163 y María y Campos, op. cit., págs. 12-13).

\section{3}

Para más información sobre el declive del teatro evangelizador véase el capítulo «Causas de la decadencia del teatro misioneros en Beatriz Aracil Varón, El Teatro evangelizador: sociedad, cultura ideología en la Nueva España del siglo XVI, Roma, Bulzoni, 1999, págs. 521-557
Juan José Arrom, El teatro de Hispanoamérica en la época colonial, La Habana, Anuario Bibliográfico Cubano, 1956, pág. 50

5

Fernando Horcasitas recoge la existencia de esta representación en sus apuntes bibliográficos publicados recientemente por María Sten y Germán Viveros, Teatro náhuatl II. Selección y estudio crítico de los materiales inéditos de Fernando Horcasitas (México, UNAM, 2004). Se pueden leer en sus anotaciones: «Las cuatro apariciones de la Virgen, autor anónimo. Representación que se hace en el barrio de Tecujapa el 10 de diciembre de cada año. Organizada y dirigida por la srta. Guadalupe Loyo Sánchez, que vive en la calle de Francisco Zarco, en San Juan Coscomatepec. Ver recolección efectuada el 10 y 11 de 1951» (pág. 424; también recogida en $\mathrm{Ma}$ ría y Campos, op.cit., págs. 54 y ss.).

6

Edmundo O'Gorman, Destierro de sombras. Luz en el origen de la imagen y culto de Nuestra Señora de Guadalupe del Tepeyac, México, UNAM, 1986.

7 Ibidem, pág. 139.

8 Ibidem, pág. 127.

9

Puede ser consultada de forma integra, versión paleográfica de fray Fidel de Jesús Chauvet, en (www.proyectoguadalupe. com).

La devoción popular guadalupana en la teatralidad mexicana MÓNICA RUIZ BAÑULS 


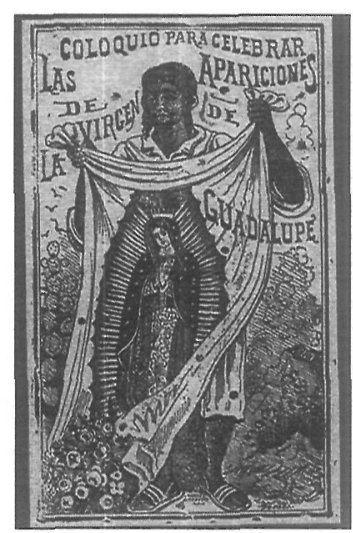

Celebraciones de Oaxaca de la Virgen de Guadalupe. Juan Diego llevando la tilma de la Virgen. 1992.

\section{0}

Información que el Señor Arzobispo de México D. Fray Alonso ed Montúfar mandó practicar sobre un sermón que el 8 de septiembre de 7556 predicó fray Francisco de Bustamante acerca del culto de nuestra señora de Guadalupe, versión paleográfica de fray Fidel de Jesús Chauvet, ibidem, folio $2 b$.

\section{1}

O’Gorman, op.cit., pág. 84.

\section{2}

Josefina Muriel de la Torre, La tradición de las pastorelas mexicanas, México, Ediciones Olivo, 1996, pág.13.

\section{3}

Término acuñado en la investigación hispanoamericanista actual por Robert Ricard en La conquista espiritual de América, México, FCE, 1986.

\section{4}

María Sten, Vida y muerte del teatro náhuatl; el Olimpo sin Promeieo, México, Secretaría de Educación Pública, 1974, pág. 13

15

Aracil, op.cit., pág. 349.

La devoción popular guadalupana en la teatralidad mexicana MÓNICA RUIZ BAÑULS indio llamado Marcos» ${ }^{10}$. Bustamante juzga en dicho sermón como idolátrico el culto guadalupano pidiendo la inmediata intervención de las autoridades para erradicarlo; asimismo, acusa a Montúfar de ser divulgador de milagros obrados por la imagen colocada en la ermita de Tepeyac, sin previa comprobación de la autenticidad de esos prodigios. Para O'Gorman, se revela a partir de estas informaciones que «toda esa devoción no podía tener más antigüedad que la del señor Montúfar en el gobierno de la mitra de México» ${ }^{11}$.

Sin pretender abordar con exhaustividad esta polémica planteada por O'Gorman, lo que me interesa recuperar es la idea central que subyace a lo largo de toda su reflexión al plantear el origen de la advocación guadalupana como una respuesta concreta del episcopado y la corona española en su deseo de cohesionar a la población novohispana a partir de la religiosidad. Considero que es necesario advertir cómo dicho objetivo, que funcionó con relativa eficacia durante el proceso evangelizador, vuelve a ser recuperado durante la época de la Independencia y, como veremos a continuación, es rescatado de nuevo con fuerza en la actualidad con fines muy similares.

Ahora bien, volviendo a nuestra perspectiva de lectura, cabría preguntarse cuál es el hilo conductor del proceso de las representaciones navideñas que se inicia con la milagrosa aparición mariana en el Tepeyac y pervive hasta nuestros días. Como ha señalado Josefina Muriel, es necesario advertir que

... la vía que conduce a explicar este proceso es la presencia de la madre de Jesús. Esta figura impregnó gran parte del teatro y la poesía en el virreinato de la Nueva España. Al llegar a tierras de indios, los religiosos mendicantes que deseaban llevar a cabo la evangelización de inmediato, pensaron en influir en las mentalidades de los indígenas mediante los sentidos $y$, así, pusieron todos sus esfuerzos en tal intento: pintura, mural y arquitectura. El teatro fue entonces una forma didáctica y accesible de mostrar a los indios lo que había sido el cristianismo y los misterios que predicaban. Obviamente la figura de María era centra. ${ }^{12}$.

Así pues, no se puede obviar el hecho de que el evento guadalupano tuviese lugar en medio del proceso de evangelización novohispano, característico del tiempo y de las circunstancias de la llamada «conquista espiritual» ${ }^{13}$. Por todo ello, sus representaciones se han de vincular necesariamente con un marco más amplio como es el de la institucionalización del culto mariano entre los naturales y el del teatro evangelizador. Las representaciones teatrales llevadas a cabo por los franciscanos en Nueva España durante el siglo XVI obedecieron a objetivos muy concretos de adaptación del cristianismo a un entorno del todo nuevo y, por tanto, quedaron determinadas por los planteamientos y problemas propios de dicho proceso. En este sentido, las implicaciones no sólo religiosas sino también culturales e ideológicas de esta dramaturgia se presentan como un elemento destacado en el complejo proceso de aculturación que supuso todo el proyecto evangelizador.

A la conquista territorial del Nuevo Mundo le sucedió otra, la espiritual, en la que el teatro, como medio de difusión ideológica, desempeñó una labor determinante. Como ha explicado la investigadora María Sten,

...la conquista española difiere de otras empresas similares de su época y de épocas posteriores en la medida en que se usa, al lado de las armas tradicionales, un arma poco común: el teatro. Y se puede decir, sin exageración, que el teatro fue en la conquista espiritual de México, lo que los caballos y la pólvora fueron en la conquista militar ${ }^{14}$.

Dentro de ese teatro evangelizador, son diversas las obras en las que la figura de María queda ensalzada junto a la de su Hijo, siendo la alabanza a la Virgen uno de los intereses temáticos más recurrentes. Durante el siglo XVI, como ha señalado Beatriz Aracil, el aspecto que más se destacó de la Madre de Dios en muchas de las manifestaciones dramáticas fue «su papel como intercesora de la Humanidad, aspecto fácilmente observable en representaciones como la Comedia de los Reyes Magos, La educación de los bijos o Las ánimas $y$ las albaceas $»^{15}$. En cualquier caso, como señala esta investigadora, según los datos aportados por las crónicas de Motolinía y Ponce, los franciscanos dedicaron también piezas específicas a otros momentos fundamentales de la vida de la Virgen como la Anunciación y la Visitación de Nuestra Señora a Santa Isabel (Tlaxcala, 1538) y las dos representaciones conocidas de la Asunción de Nuestra Señora (Tlaxcala, 1538 y Zapotlán, 1587).

A partir del siglo XVII, la temática teatral mariana de intercesión maternal da paso a las apariciones milagrosas $y$, muy especialmente, a las intervenciones prodigiosas de la Virgen de Guadalupe. Dichas representaciones vendrán a enriquecer la temática del teatro 
religioso en lengua indígena y se llevarán a cabo para enseñar, difundir y ganar adeptos a la idea de la aparición de la Virgen a un sencillo indígena mexicano. Pieza modélica en este sentido vendría a ser la de El Portento Mexicano, representada por primera vez durante la época virreinal y cuya primera versión castellana completa se ha publicado recientemente $^{16}$. Como ha señalado Germán Viveros:

\section{Se conocen textos equiparables a El Portento Mexicano} que han ido transitando de generación en generación, pero que cada vez que son representados padecen la mano de un adaptador que, en afán de adecuarlo a su circunstancia, lo modifica sin el respeto debido al original que ha legado la tradición. No obstante, el texto de El Portento Mexicano, en el estado en que se encuentra, debió satisfacer ampliamente la finalidad educativo-religiosa para la que fue escrito ${ }^{17}$.

Así pues, la Virgen de Guadalupe aparece en el teatro mexicano prácticamente desde que éste nace: en primer lugar, como fruto de ese encuentro entre la tradición medieval europea y la indígena prehispánica que da lugar al drama misionero y, a continuación, como expresión esencial de un pueblo que intenta comprenderse y ponerse en relación con una nueva sociedad virreinal en la que las representaciones guadalupanas tendrán una presencia notable.

Para completar esta perspectiva de lectura de la guadalupana en la teatralidad mexicana, será necesario abordar brevemente cómo hacia finales del siglo XVIII se pasa de lo que se puede llamar una "mariofanía mexicana» a una «epifanía patriótica» ${ }^{18}$, es decir, cómo se produce una lenta evolución que convierte a la Virgen de Guadalupe en estandarte de la Independencia y símbolo por excelencia de la mexicanidad.

No se puede obviar que el teatro guadalupano es una de las tradiciones dramáticas más profundas del espíritu religioso nacionalista; son diversas las representaciones que surgen en esta época en torno a la Virgen de Guadalupe ${ }^{19}$, manifestaciones en las que se busca siempre el mismo efecto social: reafirmar una identidad diferente y promover su expresión ${ }^{20}$. Además de la importancia del mito guadalupano en la fundación del pueblo mexicano y su trascendencia hasta nuestros días, conviene señalar, como ha explicado Luis de Tavira, la importancia de esta tradición teatral religiosa que «si bien proviene de las corrientes medievales del teatro litúrgico, las renacentistas de la evangelización y las alegóricas del barroco, constituye una expresión privilegiada y estricta de lo nacional mexicano, propio, otro y exclusivo» ${ }^{21}$.
Así pues, en los inicios del México independiente, la Virgen de Guadalupe se convierte en la bandera de insurrección para la población criolla, en el emblema movilizador de una conciencia extendida por todo el territorio de la nación. Y si bien es cierto que todas estas representaciones pretenden reafirmar el culto guadalupano, más por motivos de conciencia nacionalista que por fervores religiosos, en mi opinión es evidente que no podemos dejar de vincularlas al marco de la devoción popular, ya que se hace necesario recordar que estamos en una situación extrema en la que

...se alentó una religiosidad primitiva casi siempre manifestada en celebraciones paralitúrgicas, con frecuencia heterodoxas, siempre sincréticas (...). La instrucción religiosa quedó circunscrita a la educación familiar y pertenecía al dominio y deber de las madres con los hijos durante la infancia. Así se creó una verdadera tradición oral que heredaba de padres a hijos las más remotas manifestaciones del fasto litúrgico barroco: pastorelas, vía crucis, pasiones, danzas de moros y cristianos, autos de milagros, apariciones y múltiples procesiones ${ }^{22}$.

Por tanto, estamos ante unas manifestaciones teatrales en las que juega un papel esencial la religiosidad popular de una época tan específica para la historia mexicana como ésta, aunque evidentemente difuminada por un complejo contexto social y político en el que la devoción mariana se transformó en un guadalupanismo nacionalista y utópico que luchaba por un México independiente y moderno.

\section{DEVOCIÓN POPULAR MARIANA: MARCO DE REFERENCIA DE LA TEA- TRALIDAD GUADALUPANA}

Al hablar de la piedad popular mariana, diversa en expresiones y profunda en sus causas, estamos haciendo referencia sin duda a uno de los hechos eclesiales más relevantes y universales. Como explica Rodríguez Becerra, la devoción mariana se sustenta en la idea popular de que «la Virgen no es sólo la Madre del Señor y del Salvador, sino también, en el plano de la gracia, la madre de todos los hombres» ${ }^{23}$.

Considerando la teatralidad guadalupana como expresión esencial de la trayectoria

\footnotetext{
$16 \quad 17$

Horcasitas, Teatro náhuatl II, Ibidem, pág. 260. op.cit., págs. 257-323.
}

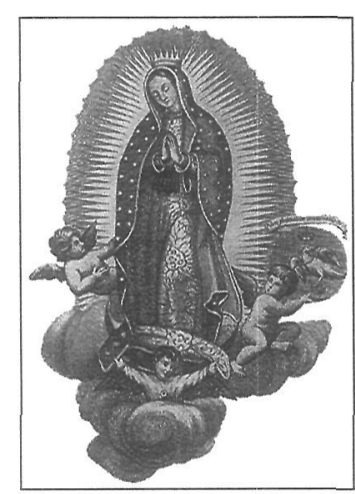

Manuel Rodríguez. Grabado en metal de la Virgen de Guadalupe con las armas mexicanas. sf.

18

Cit. en Jacques Lafaye, Quetzalcóatl y Guadalupe. La formación de la conciencia nacional de México, México, FCE, 1977, pág. 417.

19

Armando de María y Campos recoge en su estudio dedicado al teatro guadalupano una larga lista de piezas dramáticas marianas y estrenos de esta época con dicha temática, títulos entre los que destacan representaciones como la Loa para celebrar a Nuestra Santísima Madre y Señora Santa María de Guadalupe (1794) y Loa para celebrar la maravillosa aparición de Nuestra Santísima Madre María de Guadalupe (1804) de Manuel Quiroz y Campa. Para más información véase María y Campos, op.cit., págs. 39-73.

20

Considero un ejemplo paradigmático de esta perspectiva de lectura que presento el Auio mariano. Para recordar la milagrosa aparición de Nuestra Madre y Señora de Guadalupe de José Joaquín Lizardi cuyo texto completo queda recogido en Luis de Tavira, (ed.), Autos, pastorelas y dramas religiosos (1817-1862). Teatro mexicano. Historia y dramaturgia, Volumen XI, México, Consejo Nacional para la Cultura y las Artes, 1994, págs. 47-59

21

Ibidem, pág. 24.

22

Ibídem, pág. 20.

23

Álvarez Santaló, M. Buxó Rey y S. Rodríguez Becerra (coords.), La religiosidad popular, Barcelona, Anthropos, 2003, vol. I, pág. 27.

La devoción popular guadalupana en la teatralidad mexicana MÓNICA RUIZ BAÑULS 


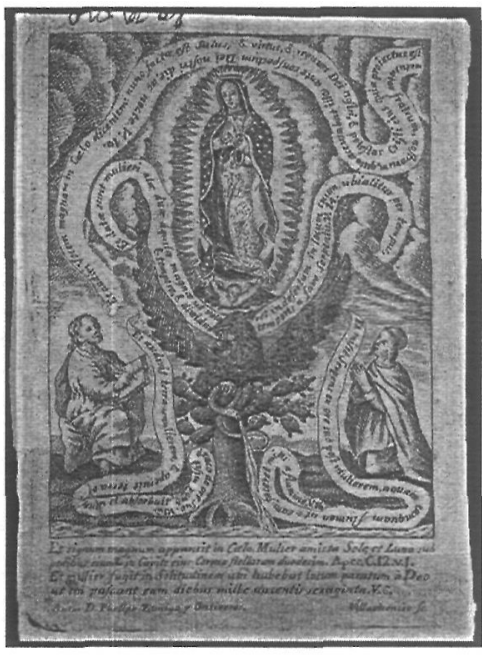

Guadalupe posada sobre las armas mexicanas y guarnecida por San Juan y Juan Diego. Miguel de Villavicencio. Siglo XVIII.

24

Ibídem, pág. 30.

25

Las fuentes de la tradición guadalupana se encuentran en lo que Francisco de la Maza llama «los cuatro evangelistas guadalupanos»: Imagen de la Virgen María de Dios de Guadalupe (1648) de Miguel Sánchez, el Nican Mopohua (̇े1646?) de Antonio Valeriano, Felicidad de México en el principio y milagrosos origen del santuario de la Virgen de Guadalupe (1675) de Luis de Becerra y la Estrella del norte de México (1681) de Francisco de Florencia (cfr. Francisco de la Maza, El guadalupanismo mexicano, México, FCE, 1984, págs. 54-94). Como ha explicado Luis de Tavira, «en estos cuatro libros, articulados en un ritmo progresivo, se va conformando la narración ponderada que viene y va de la tradición oral y encuentra sus derivaciones y correspondencias en las Informaciones de 1666, en los sermones (...), en la poesía guadalupana del barroco novohispano $y$, desde luego, del teatro guadalupano desde el siglo XVI hasta el XX» (Tavira, op.cit., pág. 27).

\section{6}

Jesús de la Vega, Devoción popular guadalupana en México, Roma, Universitat Pontificia Salesiana, 2001, pág. 73.

27

Î́bidem, pág. 78.

La devoción popular guadalupana en la teatralidad mexicana MÓNICA RUIZ BAÑULS del pueblo mexicano desde la época colonial, como forma de cohesión y definición de su identidad, estamos adentrándonos necesariamente en el ámbito de la religiosidad popular que, como todo ritual de carácter religioso, es un «complejo fenómeno polisémico que no sólo comunica un mensaje relacionado con lo sobrenatural sino también con lo económico, lo social, lo lúdico, lo étnico y con todo el sistema cultural de un pueblo» ${ }^{24}$. Desde esta perspectiva, considero necesario insertar las representaciones en torno a la Virgen de Guadalupe en el marco de la veneración y culto de esta advocación mariana, pues sólo desde la comprensión completa de esta devoción se puede comprender la vigencia actual de diversas manifestaciones teatrales en las que la Guadalupana sigue siendo símbolo cultural y religioso de todos los mexicanos.

Desde el momento en que la devoción guadalupana se convierte en una manifestación de la identidad colectiva, que no se limita a lo religioso, sino que, como hemos visto, abarca una dimensión social, ideológica y cultural, se hace conveniente señalar las diversas implicaciones que motivan su vigente presencia en las representaciones dramáticas populares. En este sentido hemos de tener en cuenta el hecho de que las primeras narraciones en torno al hallazgo y apariciones de la Virgen de Guadalupe ${ }^{25}$ fueran, a la vez que la justificación del cerro de Tepeyac como lugar de culto mariano, una creencia que la comunidad asumió como suplemento al dogma católico. Como explica Jesús de la Vega, el valor de verdad de tales relatos no podría ser cuestionado «sin cuestionar a la vez la credibilidad de la comunidad como tal. Es el mismo pueblo el que da forma a esas justificaciones y rescata la figura de la Virgen en sus diversas advocaciones volcando en ella toda su sensibilidad religiosa» 26 .

Teniendo esto presente y el hecho de que el catolicismo popular sigue siendo el sector más grande e importante de la religiosidad en el México de hoy, cuyo centro continúa situándose en la devoción guadalupana, no es de extrañar que estas informaciones recogidas a lo largo de los siglos hayan quedado absorbidas como material folklórico que sigue manifestándose en un tipo de teatralidad que refleja una forma de entender el mundo muy concreta y que todavía hoy perdura.
Asimismo, cabe advertir que, si partimos del hecho que el teatro nació en México como un discurso sincrético, fusión de la tradición medieval europea y la indígena prehispánica, la Virgen de Guadalupe como temática de la mencionada teatralidad se convierte en un eslabón esencial en la evolución de dicho mestizaje, ya que bajo esta advocación mariana no podemos ver un mero símbolo configurante de la identidad de un colectivo, sino la transformación de uno de los símbolos y expresiones esenciales de la identidad grupal del pueblo mexicano. Ello justifica la incursión de la piedad guadalupana en el marco de la devoción popular pues, como ha señalado de la Vega, podemos hablar de religiosidad popular en

...aquellas manifestaciones culturales, de carácter privado o comunitario, que en el ámbito de la fe cristiana, se expresan principalmente, no con los modos de la Sagrada Liturgia, sino con las formas peculiares derivadas del genio de un pueblo o de una etnia y de su cultura ${ }^{27}$.

De este modo, si bien es cierto que la irrupción de la devoción mariana en el ámbito de la religiosidad popular surge de la fe cristiana, no hay duda de que ésta ha tomado en México una fisonomía particular que implica una reinterpretación muy concreta del hecho mariano: la fisonomía mestiza de María de Guadalupe. Esta reelaboración fue la que permitió aunar los rasgos identificadores de la comunidad indígena y la española, nuevas formas y antiguos significados vigentes en las diversas manifestaciones teatrales populares guadalupanas que todavía hoy nos hablan de la riqueza cultural del pueblo mexicano.

Finalmente, para comprender con nitidez el fenómeno de la devoción guadalupana y su vigencia actual en la teatralidad popular, cabe plantearse si esta presencia puede ser explicada por la creencia de la comunidad en dicha advocación mariana. Como hemos visto, es el mismo pueblo mexicano el que le ha ido dando forma y justificación a la figura de la Virgen de Guadalupe volcando en ella toda su sensibilidad religiosa. Cuestionarla sería cuestionar a la propia comunidad y su identidad. La interiorización del culto mariano viene por tradición familiar, es algo que «envuelve y sobrecoge a los miembros de la familia, pero además es anclaje de nacionalidad: unión parental, comunión patriótica, identidad comunitaria y recogimiento espiri- 
tual» ${ }^{28}$. Por todo ello, considero que estamos ante una cuestión a la que no es posible dar una respuesta inequívocamente afirmativa o negativa. Como han señalado Torre Villar y Navarro de Anda:

\section{Si la aparición de la Virgen al indio Juan Diego es negada por quienes buscan explicaciones puramente científicas y materiales, la fuerza espiritual que ha ejercido a lo largo del tiempo no ha podido soslayarse $\mathrm{y}$, aun cuando se interprete al tenor de explicaciones psicológicas y sociológicas, económicas y políticas de muy diverso signo, su existencia, la fuerza de su acción y sus manifestaciones, aun las materiales, son tan vivas que resulta imposible negarlas ${ }^{29}$.}

Por tanto, instrumentalización política o cobijo espiritual comunitario, de lo que no hay duda es de que la figura de la guadalupana se presenta como «una de las primeras referencias en la endoculturación primaria del pueblo, estrechamente relacionada con la transmisión generacional, ámbito desde el cual se adquiere la sociabilidad y la identidad»30. Su presencia en diversas manifestaciones dramáticas a lo largo del acontecer histórico de México responde sin duda al hecho de que la teatralidad popular haya expresado siempre las luchas, tribulaciones y preocupaciones que han ido marcando el ritmo de las vivencias cotidianas e históricas de un pueblo.

Resulta evidente que la devoción a María de Guadalupe, enmarcada en el ámbito de la religiosidad popular, polariza muchos valores y actitudes de la vida diaria de una comunidad, no sólo en su dimensión creyente, sino también en su dimensión cultural y social. Como hemos visto, el evento guadalupano ha formado parte de aquellos momentos importantes y de gran significación para la formación de la identidad mexicana: desde el papel relevante de la aparición de la imagen en la primera evangelización, acontecimiento que polarizó en gran medida el mensaje cristiano y que selló toda la pedagogía misionera, hasta la contribución indudable en la formación de la conciencia nacional y el sentimiento patriótico.

De este modo, el pueblo mexicano acabó haciendo suyo el mensaje de la Virgen de Guadalupe, no sólo como elemento vital de su fe sino como signo de unidad nacional y símbolo por excelencia de la mexicanidad. Más allá del fenómeno y del sentimiento religioso, hay una realidad como emblema nacional insoslayable; como explica Fernández Poncela,

...sea invención o no, eso es lo que menos importa, lo destacable es el consenso en este sentido, donde las dudas se desvanecen y la claridad deja atrás a las sombras, y ése si que existe como símbolo de México por encima de todo y de todos. Es prolongación de la identidad: como pertenencia e identificación con y a la vez diferenciación de ${ }^{31}$.

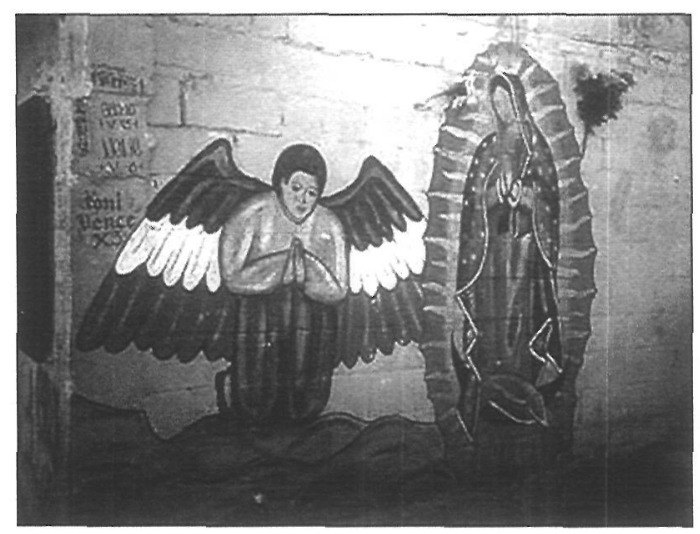

Pintura mural popular (arte chicano). Siglo XX.
En definitiva, como hemos podido observar, aproximarse al hecho guadalupano supone enfrentarse a un fenómeno cultural de gran complejidad: símbolo de la fe cristiana de los españoles durante la evangelización y absorbido después como sustancia folklórica en el ámbito popular indígena, acabará convirtiéndose en estandarte de la Independencia para llegar a nuestros días no como una formulación teológica o ideológica, sino como una imagen colectiva profundamente urdida a través de las fiestas religiosas, los avatares históricos, las costumbres y, por supuesto, la teatralidad popular.

\section{BIBLIOGRAFÍA}

Álvarez Santaló, C., Buxó Rey, M., y Rodríguez Becerra, S. (coords.), La religiosidad popular, Barcelona, Anthropos, 2003, 3 vols.

Aracil Varón, María Beatriz, El Teatro evangelizador: sociedad, cultura ideología en la Nueva España del siglo XVI, Roma, Bulzoni, 1999.

Arrom, Juan José, El teatro de Hispanoamérica en la época colonial, La Habana, Anuario Bibliográfico Cubano, 1956.

Congregación para el Culto Divino, Directorio sobre la piedad popular y la liturgia. Principios y orientaciones, Madrid, BAC, 2002.

Fernández Poncela, Anna, «Semantización política y personal de una imagen: la Virgen de Guadalupe», Cuicuilco, México, INAH, 2000, vol. VII, núm. 20, págs. 137-143.

Horcasitas, Fernando, «Las piezas teatrales en lengua náhuatl. Bibliografía descriptiva», Boletín Bibliográfico de Antropología (México), 1948, núm. XI, págs. 154-164.
28

Anna Fernández Poncela, «Semantización política y personal de una imagen: la Virgen de Guadalupe», Cuicuilco, México, INAH, 2000, vol. VIl, núm. 20, pág. 141.

29

Ernesto de la Torre Villar y Ramiro Navarra de Anda, Testimonios históricos guadalupanos, México, FCE, 1982, pág. 8.

30

Fernández Poncela, op. cit., pág. 142.

31

Ibidem, pág. 147. 
Horcasitas, Fernando, Teatro nábuatl II, coord. por María Sten y Germán Viveros, México, UNAM, 2004.

Lafaye, Jacques, Quetzalcóatl y Guadalupe. La formación de la conciencia nacional de México, México, FCE, 1977.

León-Portilla, Miguel, Tonatzin-Guadalupe. Pensamiento nábuatl y mensaje cristiano en el «Nican Mopobua», México, FCE, 2002.

Lucas Anaya, José, La milagrosa aparición de la Nuestra Señora María de Guadalupe de México, México, UNAM, 1995.

María y Campos, Armando de, La Virgen frente a las candilejas o El teatro guadalupano, México, Ediciones Populares, 1954.

Maza, Francisco de la, El guadalupanismo mexicano, México, FCE, 1984.

Muriel de la Torre, Josefina, La tradición de las pastorelas mexicanas, México, Ediciones Olivo, 1996.
Noguez, Xavier, Documentos guadalupanos, México, FCE, 1995.

O'Gorman, Edmundo, Destierro de sombras. Luz en el origen de la imagen y culto de Nuestra Señora de Guadalupe del Tepeyac, México, UNAM, 1986.

Ricard, Robert, La conquista espiritual de América, México, FCE, 1986.

Tavira, Luis de (ed.), Autos, pastorelas y dramas religiosos (1817-1862). Volumen $X I$. Teatro mexicano. Historia y dramaturgia, México, Consejo Nacional para la Cultura y las Artes, 1994.

Torre Villar, Ernesto de la y Navarro de An$\mathrm{da}$, Ramiro, Testimonios históricos guadalupanos, México, FCE, 1982.

Vega, Jesús Hector de la, Devoción popular guadalupana en México, Roma, Universitat Pontificia Salesiana, 2001. 


\title{
ABRAHAM E ISAAC, PERSONAJES DE UNA EPIFANÍA EN UNA COMUNIDAD INDÍGENA DE YUCATÁN
}

\author{
ÓSCAR ARMANDO GARCÍA GUTIÉRREZ
}

\section{RESUMEN}

En el poblado de Dzitnup, en el oriente de Yucatán, se asienta una comunidad campesina maya parlante que ha preservado una tradición centenaria: la celebración anual, desde la Navidad hasta la Epifanía, de una danza dialogada de Abraham e Isaac.

Esta danza se lleva a cabo en el atrio y en el interior de la pequeña iglesia parroquial del lugar. El propósito de esta danza es mostrar la manera en que Abraham e Isaac protegen al Niño Dios (que se encuentra en un pesebre en el interior de la iglesia) del posible rapto del Diablo o del Mal. Participan tres ejecutantes en la representación y constantemente interactúan con el público asistente, principalmente con los niños.

La pregunta es: ¿qué relación pueden tener Abraham e Isaac con las celebraciones navideñas? ¿Se trata de una espontánea adaptación de los indígenas mayas a la liturgia cristiana o podríamos estar ante un festejo con posibles antecedentes medievales? Trataremos de hacer un recorrido histórico de los procedimientos de evangelización en Yucatán en los siglos XVI y XVII para poder rastrear una comunicación entre esos acontecimientos y las fiestas que actualmente celebran los indígenas mayas. El artículo explicará la estructura de la celebración y tratará de plantear las diversas fuentes de esta peculiar fiesta yucateca.

\section{ABRAHAM AND ISAAC: CHARACTERS IN AN EPIPHANY IN A YUCATAN INDIGENOUS COMMUNITY}

\footnotetext{
ABSTRACT

In the village of Dzitnup, in the eastern Yucatan, lives a Mayan-speaking peasant community which has kept a centenary tradition: the annual dialogued dance celebration from Christmas to the Epiphany between Abraham and Isaac.

This dance, performed in the atrium and interior of the small parish church, aims to show how Abrabam and Isaac protect Baby Jesus (in a crib inside the church) from a possible kidnapping by the Devil and from Evil. Three performers take part in the representation and constantly interact with the attending public, principally with children.

The question is: What relationship could Abraham and Isaac bave with the Christmas festivities? Is it a spontaneous adaptation of Mayan Indians to Christian liturgy or might we be witness to a festival with possible mediaeval antecedents? An historical trace of evangelist procedures in Yucatan in the $16^{\text {th }}$ and $17^{\text {th }}$ Centuries will be attempted in order to track a link between those events and the festivals presently celebrated by the Mayan Indians. The article will lay out the celebration's structure and attempt to suggest the diverse sources behind this particular Yucatan feast.
}

Óscar Armando García

Gutiérrez

Licenciado en Literatura Dramática y Teatro por la Universidad Nacional Autónoma de México. Maestro en Historia por la Universidad Católica de Lovaina (Bélgica). Doctor en Historia del Arte por la UNAM. Sus lineas fundamentales de investigación giran en tomo al espacio teatral, en especial en el período novohispano; a este tema ha dedicado numerosos trabajos en publicaciones mexicanas e internacionales. Como especialista en teatro mexicano, participa además en los consejos editoriales de las revistas Escénica, Extensión y Espacio Escénico. Ha impartido docencia en la Escuela Nacional de Arte Teatral del INBA, la Universidad Iberoamericana, el Institut del Teatre de Barcelona y Universidad de Perpignan (Francia). Ha sido Director fundador del Centro de Investigaciones Escénicas de Yucatán (CINEY) del Instituto de Cultura de Yucatán. Actualmente es Profesor a Tiempo Completo en la Facultad de Filosofía y Letras de la UNAM, investigador en el Sistema Nacional de Investigadores de México y Presidente de la Asociación Mexicana de Investigación Teatral (AMIT).
Abraham e Isaac, personajes de una Epifanía en una comunidad indígena de Yucatán

OSCAR ARMANDO GARCÍA GUTIERREZ 


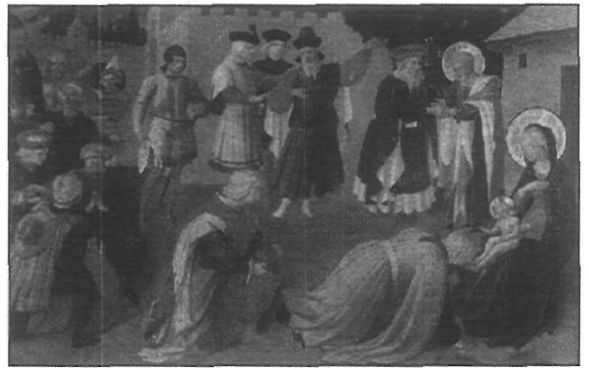

La Adoración de los Magos. Anónimo siglo XV.
En Dzitnup, pequeño poblado del oriente de Yucatán (a unos cuantos kilómetros de la ciudad de Valladolid), se asienta una comunidad campesina maya-parlante que ha preservado una tradición centenaria: la celebración anual (en la Navidad y la Epifanía) de una danza dialogada, denominada Abraham e Isadac.

La fiesta ha sido motivo de múltiples 1 Luis Pérez Sabido (Bailes y danzas tradicionales de Yucatán, Mérida, DIF-Yucatán, 1983) hizo uno de los primeros trabajos de análisis y recopilación de esta fiesta; Fernando Muñoz (Tea tro maya peninsular, Mérida, Ayuntamiento de Mérida, 2000) considera en su trabajo la hipótesis de que este evento podría tener un enlace con la pieza de teatro evangelizador El sacrificio de Isaac y Donald Frischmann («Transformaciones y trascendencia en el arte ritual y escénico de los mayas peninsulares», Investigación Teatral, núm. 5, enero-junio 2004, págs. 9-201 postula que las fuentes de esta celebración son sustancialmente de origen indígena.

2

CF. Armando García Gutiérrez, «Los espacios escénicos en Tikal" en Cuadernos de Arquitectura Mesoamericana, (División de Estudios de Posgrado. Facultad de Arquitectura. UNAM!, núm. 6, noviembre 1985, págs. 69-86.

3

Cf. Óscar Armando García, «La capilla abierta: espacio, representación y poder institucional en la Nueva España» en Daniel Meyran, Alejandro Ortiz y Francis Sureda (eds.), Teatro y poder, Perpignan, Presses Universitaires de Perpignan, Collection Études, 2002, págs. 285-296

4

Nos basaremos principalmente en la investigación de Peter Gerhard La frontera sureste de la Nueva España, México, UNAM, 1991, y en el trabajo historiográfico de Stella Ma. González Cicero, Perspectiva religiosa en Yucatán, 1517 1571, México, El Colegio de México, 1978

Abraham e Isaac, personajes de una Epifanía en una comunidad indigena de Yucatán

ÓSCAR ARMANDO

GARCIAA GUTIÉRREZ análisis por parte de algunos investigadores quienes, en su momento, han planteado diversas hipótesis sobre los orígenes, influencias y formato de esta celebración'; sin embargo el objetivo particular del presente artículo es desentrañar otra faceta de la fiesta: sus posibles vínculos con celebraciones medievales europeas. Ante esta representación, el espectador actual podría preguntarse qué relación pueden tener los personajes de Abraham e Isaac con las celebraciones navideñas y si se trata de una espontánea adaptación de los indígenas mayas a la liturgia cristiana o podríamos estar ante un festejo con posibles antecedentes medievales. Este trabajo tratará de proponer puentes explicativos diferentes para poder dilucidar el sentido de esta singular celebración.

\section{ALGUNAS EXPRESIONES DE TEA- T'RALIDAD INDÍGENA MAYA}

La cultura maya es, sin duda, una de las más esplendorosas de la historia. A medida que avanzan los descubrimientos arqueológicos y se analiza la compleja estructura de su civilización, vamos comprendiendo los impresionantes avances que los mayas tuvieron dentro del conocimiento en general (matemáticas, astronomía, escritura, arquitectura, escultura, pintura, etcétera). Su complejidad cultural fue correspondiente a su complejidad religiosa, paralela al resto de las culturas mesoamericanas, dentro del denominado periodo clásico (siglos IX al XIII de nuestra era). Esta religiosidad era el centro de sus actividades, lo que llevó a los mayas a consolidar una compleja red de celebraciones rituales, bajo un severo cumplimiento calendárico.

Dentro de la región mesoamericana, fue de los mayas de quienes contamos con el único vestigio de un diálogo que pudo haber tenido cercanía formal con aquello que nosotros denominamos drama: el Rabinal Achi. No obstante, también tenemos otros vestigios que nos confirman que los mayas tuvieron entre sus fiestas algo que pudo haber tenido un formato análogo al teatro occidental. Estos vestigios son, principalmente, algunas representaciones de disfraces en registros iconográficos (estatuillas de Jaina o los murales de Bonampak), o bien el uso de explanadas que fueron utilizadas como espacios de representación ritual colectiva, con graderías para espectadores y un área de actividad, tal fue el caso de los Complejos Gemelos y la Arena en Tikal, o bien ciertas plazas de otras ciudades del área como Copán, Chichén Itzáa y Dzibilchaltún ${ }^{3}$.

Antes de continuar con esta revisión, es necesario apuntar que, cuando mencionamos el concepto de teatralidad maya, nos estamos refiriendo a una continuidad festiva que tiene vigencia en la región. Los mayas que hoy habitan la península de Yucatán y parte de Centroamérica (varios de ellos descendientes directos de los mayas prehispánicos), tienen como particularidad el desarrollo de una compleja ritualidad, producto de su principal oficio: el cultivo de la tierra. Estamos ante una cultura de la tierra que sigue celebrando puntualmente (como toda comunidad agrícola) los ritmos propios del proceso cíclico de la labranza. Alrededor de este ciclo, el pueblo maya ha desarrollado una serie de fiestas (acorde con los principales onomásticos cristianos) que nos ofrecen su peculiar concepción de un mundo mítico.

\section{BREVE SEMBLANZA DE LA CON- QUISTA Y EVANGELIZACIÓN EN YU- CATÁN ${ }^{4}$}

Para una mejor comprensión de la fiesta que analizaremos posteriormente, nos parece pertinente hacer un breve repaso sobre los principales acontecimientos de los procesos de evangelización en el área de Yucatán. La especificidad de estos procesos podría ofrecernos algunas pistas significativas sobre las maneras en que la ritualidad popular maya se fue configurando a través de diferentes factores, entre ellos la incursión de la ritualidad religiosa europea en la región.

Desde las primeras incursiones españolas por territorio mesoamericano hechas por Hernández de Córdoba, Juan Grijalva y Hernán Cortés (entre 1517 y 1519), esta zona fue considerada solamente un buen punto estratégico para los trayectos de las expediciones hispanas provenientes de la isla de Cuba. Esto explica que la colonización de Yucatán 
se iniciara de manera tardía, a comparación de otras regiones, como el Altiplano, Occidente y Guatemala.

Podemos dar como fecha del inicio de la colonización de Yucatán el 8 de diciembre de 1528, cuando la expedición de Francisco de Montejo hizo posible la capitulación del poblado indígena de T'Ho (actual Mérida), pero no será sino hasta el 6 de enero de 1542 cuando oficialmente se funde Mérida como ciudad hispana. Este hecho confirma la poca importancia que había tenido la región, tanto para conquistadores como para los gobiernos virreinales, pues Yucatán no se encontraba entre las zonas prioritarias para la explotación de recursos naturales, tan vitales para la corona española. Los religiosos habían acompañado a los capitanes y soldados en estas incursiones; sin embargo, la primera visita a la zona hecha por un franciscano será la de fray Jacobo de Tastera en 1537, quien preparará el camino de los primeros procesos de evangelización de la región. Para 1544, Mérida estuvo comprendida dentro del territorio de la Provincia del Santo Evangelio.

En 1545 llegan a la Península de Yucatán los frailes franciscanos Luis de Villalpando, Melchor de Benavente y Juan de Herrera, enviados por fray Toribio Motolinía ${ }^{5}$ desde Chiapas. Un cuarto fraile, Lorenzo de Bienvenida, llegaría ese año a territorio yucateco desde Guatemala, vía Bacalar, lugar donde estableció una incipiente misión. Los tres primeros se encargarán de preparar la fundación del convento de San Francisco de Campeche (1545), la misión de Mérida (1546) y la misión de Maní (1547), junto con las primeras tareas de adoctrinamiento entre la población indígena, conformándose de esta manera la primera ruta misionera de Yucatán. En 1548, los franciscanos yucatecos son nombrados Procuradores por la misma orden, acontecimiento que sienta un precedente especial para los futuros procesos de secularización en décadas posteriores.

En 1549 se realiza el primer capítulo custodial de Mérida. Para entonces, existen ya establecidos cinco conventos (construidos aún de palma, madera y adobe): Mérida, Campeche, Maní, Izamal y Conkal. La región se separa de la Provincia del Santo Evangelio y se convierte en la Custodia de San José. Ese año también llega a tierras yucatecas fray Diego de Landa, quien comienza la construcción de conventos en piedra. En Izamal, Landa encuentra el sitio adecuado para la construcción de un convento y un seminario.
1561 será un año decisivo para los procesos de evangelización en Yucatán, pues se elige a Diego de Landa como Provincial de San José de Yucatán y, a la vez, es el momento de la llegada del obispo Francisco del Toral, iniciándose con ello la secularización de la región. Un año después, Landa realiza el proceso de Maníb. Este polémico incidente lo lleva de retorno a España, para volver en 1572 como obispo de Yucatán. Para 1571 llega el último grupo de franciscanos peninsulares, entre ellos fray Blas Cotello.

La historia de la misión franciscana

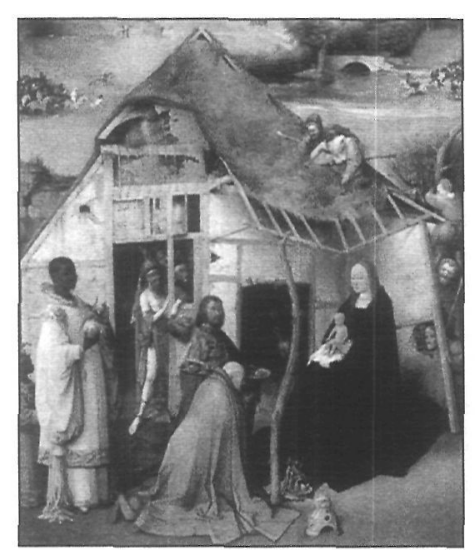

La adoración de los Reyes Magos. El Bosco (detalle). 1510. Museo del Prado. en Yucatán debe revisarse junto con la historia de la secularización, fenómeno común en diversas regiones durante el siglo XVI en la Nueva España”. No será sino hasta 1560 que se designa al fraile franciscano Francisco de Toral como encargado del Obispado de Yucatán. Cuando Toral llegó a Yucatán, condenó principalmente que los franciscanos se hubiesen atribuido funciones de inquisidores en el proceso contra idolatría de Maní. Los franciscanos yucatecos tenían como defensa el haber sido nombrados procuradores, lo que les permitía articular juicios contra la idolatría. Toral, quien había tenido experiencias evangelizadoras con los nahuas del Altiplano, criticó los métodos utilizados por los franciscanos de la Provincia de Yucatán; por lo tanto, estableció el fortalecimiento de instrucciones como el bautismo, la pila bautismal oculta, la doctrina, la ejecución de bailes durante el día y la construcción de una cerca alrededor de los atrios conventuales para impedir el paso de las bestias. La etapa más intensa de su trabajo episcopal se dio entre el 1561 y el 1569 .

En resumen, la evangelización de Yucatán en el siglo XVI, aunque tardía con respecto al resto de las provincias, tuvo también la participación activa de religiosos que ya habían tenido experiencias evangelizadoras en otras regiones, y que consolidaron paulatinamente la occidentalización de la zona a través de su labor de conversión religiosa.

\section{DZITNUP, PRIMER REGISTRO POR PARTE DEL PADRE PONCE}

Uno de los registros hispanos más tempranos de la población de Dzitnup que conservamos es la noticia que el padre Ponce registrará en su relación de la siguiente manera:
5

Nombre indigena de fray Toribio de Benavente, el célebre franciscano autor de la Historia de los indios de la Nueva España, relato que recopila su experiencia principalmente en la ciudad de Tlaxcala en años anteriores.

6

Fray Diego de Landa manda a los caciques mayas que traigan a Maní todos los códices e idolos que tuvieran escondidos para prenderles fuego en una enorme hoguera. Con ello se perdieron documentos valiosos de la historia de los mayas pero, paradóiicamente, Landa también turo el impulso de conservar esa historia en su obra Relación de las cosas de Yucatán a través de diversos informadores indígenas. Esta crónica recoge algunos signos de la compleja escritura maya a partir de lo cual se han podido hacer los mejores trabajos de desciframiento de los jeroglíficos mayas.

7

Ya desde el 1518 se comienzan las primeras negociaciones para proveer a Yucatán de un obispo, pero por una confusión cartográfica se deshecha la idea. La primera presencia secular en la región será un tanto casual, cuando en 1545 pasa Bartolomé de las Casas por la región, camino a Ciudad Real (Chiapas).

Abraham e Isaac, personajes de una Epifanía en una comunidad indígena de Yucatán ÓSCAR ARMANDO GARCÍA GUTIÉRREZ 


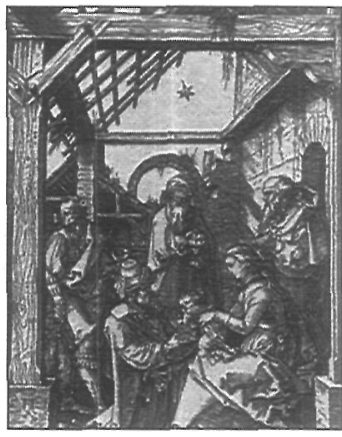

Adoración de los Reyes. Alberto Durero. Grabado. 1511.

\section{8}

Antonio de Ciudad Real, Trarado curioso y docto de las grandezas de la Nueva España, México, UNAM, 1993, tomo II, pág. 327

\section{9}

Ciudad yucateca cercana al norte de Valladolid, en donde la iglesia tiene como advocación principal a los Reyes Magos. Las imágenes son ampliamente veneradas por los habitantes de la región.

\section{0}

Principalmente el canto de villancicos es interpretado por mujeres, por lo tanto en sentido estricto estaríamos ante "Pastoras». Esto sucede en otras pastorelas indígenas, como la que se desarrolla en Santa Fe de la Laguna, en la zona lacustre de Michoacán

Abraham e Isaac, personajes de una Epifanía en una comunidad indígena de Yucatán

OSCAR ARMANDO GARCÍA GUTIÉRREZ
Jueves veintiocho de julio [1588] salió [el padre Ponce] de Zaquí [actual Valladolid] a las dos de la mañana, y andada una legua de razonable camino llegó a un pueblo de aquella guardianía llamado Citmop, donde aunque era muy de noche, le estaban los indios aguardando con muchas ramadas y dos danzas, una de mochachos y otra de indios grandes. Pasó adelante después de haberles agradecido su devoción...8.

El pasaje es interesante por varios motivos. El primero es que, desde finales del siglo $\mathrm{XVI}$, la población tenía una conexión importante con Zaquí, actual ciudad de Valladolid. $\mathrm{El}$ siguiente es que Ponce haya sido recibido justamente con «ramadas» $\mathrm{y}$ «danzas» por parte de muchachos y adultos mayas, como si esta manera de festejo tuviera una suerte de continuidad hasta nuestros días. Sin embargo, este posible nexo se pierde por la falta de otros registros en siglos posteriores. No será sino hasta fines del siglo XIX cuando se recuperan los referentes más remotos de la fiesta que nos ocupa.

\section{DESCRIPCIÓN DE LA FIESTA DEL ABRAHAM E ISAAC DE DZITNUP}

La fiesta de Abraham e Isaac se lleva a cabo en el atrio y en el interior de la pequeña iglesia parroquial de Dzitnup, hoy una pequeña comunidad maya dedicada a las labores del campo. Si quisiéramos hablar de un argumento en concreto de esta representación sería la manera en que Abraham e Isaac protegen al Niño Dios (que se encuentra en un pesebre en el interior de la iglesia) del posible rapto del Diablo o del Mal. Participan tres ejecutantes en la representación que constantemente interactúan con el público asistente, principalmente con los niños. En sí, Abraham e Isaac es una representación compleja en donde se manifiestan y funden expresiones reconocibles de danza, procesión, juegos, música y diálogos durante la celebración.

La representación se lleva a cabo en la noche del 24 de diciembre y del 5 de enero, para amanecer al siguiente día. El festejo es organizado por un selecto grupo de ancianos de la comunidad que se proclaman como mayordomos de la parroquia dedicada a san Andrés. Como dato revelador, el párroco no oficia durante estos días ni está presente como espectador. No se tiene un cálculo certero desde cuándo se lleva a cabo este evento, pero, como mencionamos con anterioridad, los investigadores que han trabajado el tema plantean dos posibilidades: su celebración centenaria desde tiempos remotos o bien que se trate de una conmemoración de unos ciento cincuenta años aproximadamente. Lo cierto es que estos cálculos requieren de una mayor documentación e indagación. A manera de recorrido general, las partes principales de la fiesta son:

\section{Novenario}

Al ocultarse el sol, un grupo de mujeres se reúne en el interior de la parroquia para iniciar el rezo y canto de villancicos, alternados en maya y en español. El novenario es el que se dedica tradicionalmente a los Reyes Magos de Tizimín" por parte de los «Pastores» o rezanderos ${ }^{10}$.

\section{Sacristía}

En la sacristía se han dado cita los danzantes de la fiesta (a manera de camerino), en donde se visten y se preparan. Los personajes son Abraham, Isaac y el Mal o Diablo. Generalmente se mantiene en secreto la identidad de los danzantes. De la puerta que da acceso al interior del templo surgen los personajes de Abraham e Isaac con velas e inician la procesión de fieles por el pasillo central, desde el altar hasta la puerta principal de la parroquia. El Mal sale por la puerta que da al exterior para realizar paralelamente sus rutinas en el atrio.

\section{Juegos en el atrio}

De manera simultánea, en el atrio de la parroquia el Diablo/el Mal comienza a interactuar con los niños, quienes en un juego han desmembrado al Mal; las partes han sido repartidas entre la población de manera simbólica y lúdica. El proceso lúdico del desmembramiento inicia con una rutina del Mal quien, con su bastón, gira en su eje durante unas trescientas veces. Cuando termina, exhausto, algún integrante de la comunidad realiza el mercadeo de las partes del Mal, lo que permite una interrelación con los niños cuando las partes son subastadas por medio de diálogos picarescos.

\section{Puerta del templo}

Cuando Abraham e Isaac llegan a la puerta, cruzan el umbral, se voltean hacia el altar y se sitúan unos pasos fuera del templo. Los fieles, dentro del templo, permanecen viendo todo esto hacia el exterior, en el límite que marca la puerta principal.

Los fieles inician un canto de villancicos con exaltación a la Sagrada Familia, mientras 
Abraham e Isaac ejecutan una danza, emulando el trote de un caballo. Este ritmo es acompañado por el tunkul (tambor de madera) que se encuentra en el atrio exterior (pero cercano a la escena). Participan también las campanas de la parroquia, las cuales contrapuntean rítmicamente con el tunkul y el trote de los personajes, en un espectacular y complejo diálogo de sonidos, textos, ritmos y formas.

En este momento, cumbre tal vez, de la danza, los participantes (fieles y danzantes) marcan espacialmente dos áreas de representación de manera dialógica: el interior del templo y el atrio exterior. En el interior se cantan villancicos y se localiza, resguardada, la imagen del Niño Dios; en el exterior se encuentran los danzantes que defienden al Niño (Abraham e Isaac), el danzante que amenaza (el Mal), los niños y el tambor indígena.

Posteriormente, Abraham e Isaac simulan con bastones una batalla contra el Mal con bailes grotescos en el atrio. Los niños rodean el baile/juego. El 24 de diciembre este juego escénico lo ejecutan los Doce Apóstoles (doce adolescentes), quienes, a través de una ronda, impiden al Mal atacar a Abraham e Isaac y, por consecuencia, al Niño Dios que se encuentra «resguardado» en un pesebre dentro del templo. El Mal ha sido eliminado y desmembrado por la comunidad a través de los juegos anteriormente mencionados. Al finalizar esta batalla, todos los fieles, acompañados por Abraham e Isaac, se dirigen al altar.

\section{Ofrecimiento}

El Mayordomo de la fiesta se dirige al altar y toma la imagen del Niño Dios. Esta imagen es transportada en un capelo de tela blanca y es ofrecida a los fieles en alto, de manera análoga al ofrecimiento del Santísimo Sacramento en la liturgia. La diferencia es el espacio, pues este ofrecimiento no se hace en el altar, sino en el arranque del pasillo central del templo.

\section{Procesión}

Después del ofrecimiento del Niño Dios, un grupo selecto de fieles (o rezanderos) se dirige al altar y toman las imágenes de José, la Virgen María, los tres Reyes Magos y la Cruz, que toma la delantera para iniciar una procesión al interior del templo. La procesión consta de seis vueltas en el pasillo central desde el altar hasta la puerta de la iglesia. Al finalizar la procesión, los integrantes depositan de nuevo las figuras en el altar. Con esto finaliza el evento nocturno ${ }^{11}$.

\section{Recolta del aguinaldo}

A la mañana siguiente, los jóvenes que han interpretado a Abraham, Isaac y el Mal (aún disfrazados) recorren las calles del pueblo para iniciar la recolta del aguinaldo, en una pequeña procesión en donde se integran: el mayordomo de la fiesta portando a la imagen del Niño Dios, músicos y sobre todo niños de la comunidad. El procedimiento de esta etapa es el siguiente:

Abraham e Isaac se presentan ante la puerta de la casa de alguno de los vecinos para recibir una medida (1/2 kilogramo aproximadamente) de granos de maíz o frijol, la cual es depositada en una carretilla. Mientras tanto, el Mal incursiona en el huerto de la casa para robarse los frutos, principalmente naranjas, las que acumula en una manta. Los niños que acompañan la procesión juegan a descubrir la fechoría del Mal, quien huye por la calle, mientras lanza naranjas a los niños que corren tras él.

Los personajes de Abraham e Isaac interpretan una pequeña danza (con ritmo de jota) en el portal de cada casa, en agradecimiento a la contribución hecha por el vecino. Con este baile inicia el desplazamiento a otra casa de la comunidad para repetir el acto antes descrito.

Al finalizar la jornada se reúne todo el grano recabado para ser vendido en el mercado. La ganancia de lo que fue vendido se guarda para los gastos de la fiesta del siguiente año.

\section{PERSONAJES DE LA FIESTA}

\section{Abraham}

También denominado Suku'n (hermano mayor ${ }^{12}$. Utiliza una máscara de madera con marcas de arrugas en el rostro, para enfatizar la edad del personaje. Las máscaras de Abraham e Isaac son elementales en su confección y sus formas, sin embargo son excepcionales en la región, debido a que en todo Yucatán no existen otras manifestaciones escénico-dancísticas donde se utilicen máscaras.

\section{Isaac}

Su denominación en maya es Its'in (hermano menor) ${ }^{13}$. Según Frischmann es posible que el parecido fonético del nombre en maya del personaje haya generado la tradición de representarlo e identificarlo como «Isaac». Pero existe un dato aún más revelador: en su máscara encontramos labrada una estrella en la frente, la cual representa la estrella de Belén, según información directa de don Eustaquio

\begin{abstract}
11
Según varios testimonios, la fiesta generalmente tiene una duración aproximada de doce horas; sin embargo, cuando tuvimos la oportunidad de presenciar este evento (enero 2003), culminó alrededor de la una de la madrugada, porque al día siguiente los niños y jóvenes tenían cursos en las escuelas. Existen algunos registros videográficos de esta fiesta que han sido filmados en diversas ocasiones durante las dos últimas décadas del siglo $X X$ y principios del $X X \mid$, entre los que destacan: La danza de Abraham e Isaac (Dzitnup), 24 de diciembre 1998, Instituto de Cultura de Yucatán y El protector de la luz, realización de Óscar Urrutia, Dirección de Comunicaciones / Dirección de Artes Escénicas / CINEY / Instituto de Cultura de Yucatán (2003). Estos materiales se encuentran en el acervo videográfico del Centro de Investigaciones Escénicas de Yucatán (CINEY)
\end{abstract} en Mérida

12

Frischmann, op. cit., pág. 15.

13

Ibidem. 
Don Eustaquio Poot es el actual responsable de la mayordomía de la fiesta y también es el tallador de las máscaras en madera de Isaac y Abraham.

15

Frischmann, op. cit., pág. 15.

16

Este trabajo exegético fue realizado en colaboración con Diana Torres.

17

Relación que aparece en las interpretaciones de la Biblia desde los Santos Padres y también en la tradición teatral medieval, aspecto sobre el que intentaremos profundizar en fuluros trabajos.

18

Cf. Luis Astey, Dramas litúrgicos del occidente medieval. México, México, El Colegio de México, 1992.

19

No sería aventurado pensar que la situación fronteriza de esta fiesta portuguesa con España haya podido facilitar su comunicación a tierras americanas. La noticia de este evento fue transmitida al autor por el doctor Francesc Massip en noviembre de 2004 en Barcelona.

20

También denominada popularmente en México como «Nacimiento».

Abraham e Isaac, personajes de una Epifanía en una comunidad indígena de Yucatán

ÓSCAR ARMANDO

GARCÍA GUTIÉRREZ
Poot ${ }^{14}$. Tanto Isaac como Abraham visten una túnica corta azul y pantalones de mezclilla. Los dos personajes portan sendas varas a manera de bastones.

\section{El Mal}

Este personaje es identificado por la comunidad como K'akas ba'al (cosa maligna y fea/Diablo $)^{15}$. A diferencia de los dos anteriores, este personaje lleva una máscara de animal, sin definición entre una figura equina o porcina, confeccionada en piel. Porta una especie de overol que permite ubicarlo dentro de un ámbito menos extraordinario que los otros dos personajes bíblicos.

\section{RELACIÓN TEMÁTICA ENTRE LOS PERSONAJES BÍBLICOS DE ABRA- HAM, ISAAC Y CRISTO}

Nos parece oportuno, para el análisis de esta fiesta, destacar la relación existente entre Abraham e Isaac y la figura de Jesús; es decir, la conexión entre pasajes del Antiguo y Nuevo Testamento que permiten ofrecer una identificación entre los personajes ${ }^{16}$ :

La Nueva Alianza entre Abraham y Yahvé se encuentra presente en Génesis 15 y el nacimiento de Isaac en Génesis 21. En los Evangelios se hallan aquellos pasajes que describen los principales acontecimientos de la vida de Cristo.

Si analizamos los pasajes, Isaac es un equivalente de Cristo porque los dos fueron «corderos» ofrecidos en sacrificio por sus respectivos padres. Sin embargo, existe una primera diferencia: Abraham no concluye el sacrificio porque Yahvé (por medio del ángel) lo detiene; por su parte Cristo es sacrificado sin la oposición de Yahvé, y no existirá quien detenga este acontecimiento.

Los dos hijos (Isaac y Cristo) son pastores de ovejas. Incluso podríamos encontrar una curiosa semejanza: el sacrificio de Isaac iba a llevarse a cabo con una herida en el costado, mientras que la última herida de Cristo es hecha por un soldado, con la punta de la lanza, en un costado. De esa herida no sale sangre sino agua.

Finalmente, los dos son varones, son hijos únicos, son inocentes, libres de pecado y obedecen a sus padres por amor a ellos.

¿Sería posible entonces estar en Dzitnup ante una fiesta en donde se interpretó adecuadamente esta relación ${ }^{17}$ ? No tenemos una respuesta sólida; sin embargo, lo que podría parecer un desatino interpretativo (Abraham e Isaac en una Epifanía), podría comenzar a tener una lógica sustancial dentro del panorama ritual-religioso de una comunidad indígena. De todas maneras, es posible que esta adaptación de historias testamentarias para la celebración del nacimiento del Niño Dios y de la Epifanía tenga aún más entrecruces de diferentes fuentes religiosas, rituales y temáticas.

\section{INTERPRETACIÓN DESDE LA PERS- PECTIVA DE LA TEATRALIDAD ME- DIEVAL}

¿Cuáles podrían ser posibles referentes medievales de esta fiesta realizada en Yucatán? Podríamos de principio proponer algunos elementos formales que están presentes en el Ordo Stellae o en el Ordo Prophetarum ${ }^{18}$. En estas piezas encontramos la presencia de la estrella como elemento de guía para los reyes de Oriente que visitan al Niño Jesús o bien la presentación del linaje de la familia de David. Como comentamos anteriormente, en la fiesta maya se identifica a Isaac como portador de la estrella de Belén.

Otro posible referente podría ser las festividades que aún hoy en día se llevan a cabo en varios puntos de la península ibérica (con evidencias de formatos medievales), como es el caso de la fiesta de los Rapaces, celebrada en el recóndito poblado de Barge, en la región de Tras os montes, Braganza, en Portugal. Esta región es limítrofe a Zamora, (España), donde también se celebra la fiesta del Zangarrón ${ }^{19}$. Esta fiesta portuguesa es una celebración campesina, hecha también en Navidades; en ella también los jóvenes de la localidad juegan a defenderse en batallas de naranjas, disfrazados algunos de ellos como representaciones del mal.

La fiesta yucateca nos ofrece, como uno de sus más importantes símbolos, el manejo del Niño Dios como imagen incorporada dentro del contexto de la representación de pesebre al interior del templo. Es posible, por lo tanto, que podamos indagar, como otra pauta de referente medieval, la arraigada tradición franciscana del Pesebre ${ }^{20}$.

Cabe destacar la manera en que la fiesta en Dzitnup tiene como resolución ritual una procesión final en el interior del templo. Este es un formato poco frecuente en celebraciones religiosas actuales en México y nos remite a la manera en que, en la Europa medieval, se llevaban a cabo procesiones de esta naturaleza. 
Por último, nos parece oportuno tratar de explicar hipotéticamente la integración de personajes veterotestamentarios en una fiesta navideña: es posible también que algún párroco, versado en aspectos teológicos, hubiera hecho esta adecuación para fortalecer la Historia Sacra dentro de una comunidad que, probablemente, tenía arraigada esta festividad (con personajes similares) como parte de un cosmos netamente indígena.

A pesar de que no contamos con ningún antecedente temático de otra fiesta en México o en Europa, no se descarta la posibilidad de que, en algún momento dado, podamos encontrar documentación de alguna pieza de teatro religioso en donde se consigne la convivencia «a-histórica» entre Abraham, Isaac y la figura infante de Cristo.

\section{CONSIDERACIONES FINALES}

La fiesta de Abraham e Isaac en Dzitnup es un evento vivo de múltiples lecturas. Es muy probable que estemos ante un fenómeno de adaptación ritual indígena de un mito cristiano, en donde se conmemora, a través de los personajes de Abraham e Isaac, lo nuevo y lo viejo, el mundo pagano y el mundo sacro. La representación evidencia, a través de los personajes, la manera en que una comunidad ofrece testimonio de adoración y protección a la figura inocente e indefensa del Niño Dios. Los defensores de la amenaza son dos personajes que proceden del mundo del Antiguo testamento, pero que pertenecen en linaje a la cristiandad. Abraham e Isaac son finalmente intermediarios y defensores en esta historia de convivencia entre dos órdenes en contraposición. El Mal es la fuerza que amenaza con la posibilidad de un rapto o de una trasgresión al espacio sacro (el interior de la parroquia), pero esta amenaza no es una figura temible, sino lúdica y jocosa. El Mal transita solamente en el atrio, en el exterior, en el espacio donde puede convivir con lo «viejo», con el orden viejo donde se encuentran los instrumentos musicales y rítmicos indígenas. El Mal, a través de juegos, será dominado por los jóvenes y por los personajes protectores del Niño, el cual reposa en el espacio nuevo, como representación de la nueva deidad, del orden nuevo, de la nueva religiosidad triunfante. Como sucede con algunas danzas de la Conquista guatemaltecas, la comunidad podría también estar conmemorando la transición de la religiosidad indígena a la religiosidad cristiana. En este evento en particular, la batalla no la libran personajes históricos del contexto americano, sino de la historia religiosa cristiana y con la presencia de un elemento más abstracto, el Mal, que puede representar lo antagónico desde las perspectivas tanto nativas como europeas.

Al no contar con las trazas suficientes, resulta complejo dar seguimiento, a través de la his-

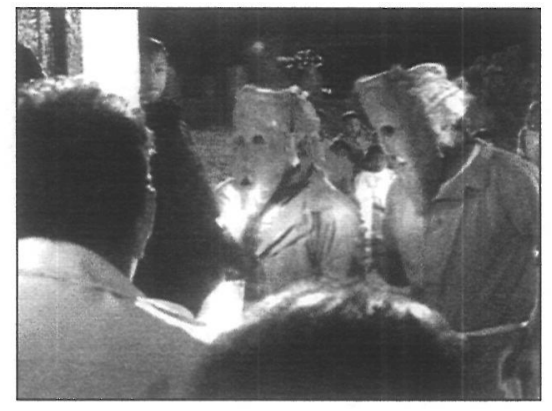

Representación de Abraham e Isaac en Tzinup. Foto de Raquel Araujo. toria colonial de la región, del impacto que las primeras propuestas de cristianización tuvieron entre los indígenas mayas. Sin embargo el Abrabam e Isaac de Dzitnup nos puede ejemplificar de manera clara cómo una comunidad se apropia, con elementos indistintos, de sus particulares necesidades de conmemoración. Este evento nos presenta un escenario (como toda fiesta del estío del hemisferio norte) en donde durante la noche más larga (o vieja) surge la deidad de la nueva luz. El orden nuevo ante el orden viejo. Si lo observamos así, esta fiesta podrá tener, para nuestra mirada, más sentido, más explicaciones, que si se tratara de un simple, espontáneo $\mathrm{y}$ «folklórico» desatino interpretativo de una comunidad. ¿Hasta dónde podríamos encontrar vestigios de una cultura y la otra? ¿Hasta dónde determinar la presencia de algún elemento de origen medieval en una expresión cultural americana? Ofrecemos una exposición general de los elementos de este evento para poder profundizar en un trabajo posterior. Por lo pronto, nos parece oportuno insistir que en el estudio de festividades de esta naturaleza pueden convivir elementos de ritualidades populares autóctonas y elementos supervivientes del mundo medieval.

Indudablemente el Abrabam e Isaac de Dzitnup es una de las fiestas más complejas de las que hemos tenido noticia en el amplio panorama de la ritualidad indígena de nuestro país, y merece, por tanto, incorporarla al estudio de nuestra teatralidad.

\section{BIBLIOGRAFÍA}

Astey, Luis, Dramas litúrgicos del occidente medieval, México, El Colegio de México / CONACYT / ITAM, 1992.

Ciudad Real, Antonio de, Tratado curioso y docto de las grandezas de la Nueva España, México, UNAM, Instituto de Investigaciones Históricas, 1993.
Abraham e Isaac, personajes de una Epifanía en una comunidad indígena de Yucatán GARCÍA GUTIÉRREZ
ÓSCAR ARMANDO 
Frischmann, Donald, «Transformaciones y trascendencia en el arte ritual y escénico de los mayas peninsulares", Investigación Teatral, núm. 5, enero-junio 2004, págs. 9-20.

García Gutiérrez, Óscar Armando, «Los espacios escénicos en Tikal», Cuadernos de Arquitectura Mesoamericana (División de Estudios de Posgrado. Facultad de Arquitectura. UNAM), núm. 6, noviembre 1985, págs. 69-86.

- , «La capilla abierta: espacio, representación y poder institucional en la Nueva España» en Daniel Meyran, Alejandro Ortiz y Francis Sureda (eds.), Teatro y po- der, Perpignan, Presses Universitaires de Perpignan, Collection Études, 2002, págs. 285-296.

Gerhard, Peter, La frontera sureste de la Nueva España, México, UNAM, 1991.

González Cicero, Stella Ma., Perspectiva religiosa en Yucatán, 1517-1571, México, El Colegio de México, 1978.

Massip, Francesc, El teatro medieval, Barcelona, Montesinos, 1992.

Muñoz, Fernando, Teatro maya peninsular, Mérida, Ayuntamiento de Mérida, 2000.

Pérez Sabido, Luis, Bailes y danzas tradicionales de Yucatán, Mérida, DIF-Yucatán, 1983.
Abraham e Isaac, personajes de una Epifanía en una comunidad indígena de Yucatán

OSCAR ARMANDO GARCIA GUTIÉRREZ 


\title{
EN BUSCA DE LA BIENAVENTURANZA: FIESTA DEL NIÑOPAN, FIESTA REPRESENTACIONAL
}

\author{
MARIZA MENDOZA ZARAGOZA
}

\section{RESUMEN}

Xochimilco, lugar de tradiciones, es el espacio donde se desarrolla la Fiesta del Niñopan, verbena en honor a la figura del Niño Jesús la cual es una escultura perteneciente al siglo XVI. La fiesta inicia cada 2 de febrero con la presentación del niño al templo después de 40 días de nacido y termina el 6 de enero con la adoración de los Reyes Magos como se describe en las Sagradas Escrituras; todo esto se lleva acabo por los fieles de la imagen en un tiempo y espacio ajeno al cotidiano.

Con base en la teoría representacional así como las estructuras representacionales propuestas por Schechner y Weisz respectivamente, se abordará la fiesta del Niñopan como fiesta representacional, actividad paralela al quehacer escénico por ser un ritual en función de la identidad social en México.

\section{IN SEARCH OF ETERNAL BLISS: \\ THE FEAST OF THE NIÑOPAN REPRESENTATIONAL FEAST}

\section{ABSTRACT}

Xochimilco, a place rich in traditions, is where the Feast of the Niñopan takes place a celebration in honour of the baby Jesus figure which is a sculpture from the $16^{\text {th }}$ Century. The feast starts every $2^{\text {nd }}$ February with the presentation of the child to the church 40 days after birth and ends on the $6^{\text {th }}$ January with the Three Wise Men's offering as described in the Holy Scriptures. All this is carried out by the faithful of the image in a time and space far from the everyday.

With a representational theoretical base as well as the representation scriptures respectively put forward by Schechner and Weisz, the feast of the Niñopan as a representation celebration will be discussed, a parallel activity to the scenic business, due to its position as a ritual of social identity in Mexico.

\section{PRESENTACIÓN}

Al sureste del Distrito Federal, capital de México, se encuentra Xochimilco, delegación dividida políticamente en 18 barrios que se encuentran en el centro, 14 pueblos a las orillas de la demarcación y varias colonias en distintos rincones. Este espacio declarado por
En busca de la bienavent uranza: fiesta del Niñopan, fiesta representacional MARIZA MENDOZA ZARAGOZA 


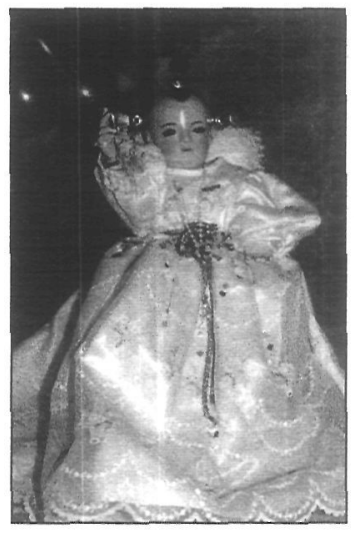

Figura del Niñopan de Xochimilco. Tallada en madera, siglo XVI.

\begin{abstract}
1
Para referirnos al Niñopan, también emplearemos los siguientes términos: escultura, imagen, figura o Niño.

2

Archivo General de la Nación, Vinculos y mayorazgos, f. 8f-8v, of, $15 f-15 v$, vol. 279 , exp. 1

3

Para referirnos a la fiesta, también utilizaremos los siguientes sinónimos: verbena, ritual y celebración.
\end{abstract}

En busca de la bienaventuranza: fiesta del Niñopan, fiesta representacional MARIZA

MENDOZA ZARAGOZA la UNESCO en 1987 como Patrimonio de la Humanidad cuenta con una rica historia, paisajes lacustres y unas fiestas de larga tradición realizadas durante el año, entre las que se encuentra la del culto al Niñopan, que llama la atención tanto de nativos como de visitantes.

El Niñopan ${ }^{1}$ es una escultura de madera del siglo XVI, representa a Jesús niño y ha peregrinado durante décadas por distintos hogares, es decir, no permanece bajo custodia del clero sino de la comunidad xochimilca. Entre su posible origen, se conoce que el último gobernante prehispánico converso de Xochimilco, Don Martín Cerón de Alvarado, dio en herencia a su esposa una escultura del Niño Dios para venderlo $y$, con el dinero obtenido, oficiarle sus misas de difunto. El testamento ${ }^{2}$ de este personaje, junto con la documentación obtenida de la investigación realizada en la Coordinación de Restauración y Conservación del Instituto Nacional de Antropología e Historia en 1985, hacen presumir que el Niño pertenece al citado siglo o principios del siguiente.

La palabra Niñopan, está compuesta de los vocablos Niño en castellano y pan en náhuatl, que significa «del lugar», dando como resultado «Niño del lugar». La escultura no permanece dentro de un templo sino bajo custodia de una familia xochimilca, que se encarga de construir una casa especial para su comodidad.

Para el desarrollo de la fiesta ${ }^{3}$ en el transcurso del año se distinguen tres roles: los mayordomos o custodios, los posaderos y los hospederos. Los primeros son la familia encargada del cuidado físico de la imagen (así como de sus pertenencias) y de preservar, sobre todo, el rito. La labor del mayordomo inicia el día 2 de febrero y culmina el siguiente año en la misma fecha. La familia del posadero es la que organiza la celebración durante un día correspondiente al novenario de posadas, del 16 al 24 de diciembre. Por último, los hospederos son la familia que festeja al Niño cualquier día entre el 3 de febrero y el 15 de diciembre.

Cabe mencionar que la imagen tiene una lista de mayordomos anotados hasta el año 2040; en caso de fallecimiento, el compromiso se hereda a los hijos o parientes cercanos. Los posaderos son buscados con 10 años de anticipación por los custodios y, para la celebración diaria, el mayordomo registra en una agenda a los hospederos a partir del mes de diciembre. Su labor inicia dos meses antes de ocupar su cargo.
Las fechas a recordar dentro de la verbena del Niñopan son las siguientes: la fiesta comienza el 2 de febrero, día de la Candelaria, fecha en que se conmemora la presentación del niño Jesús al templo a sus cuarenta días de nacido. Continuamos el 5 de febrero, día en que se realiza el traslado de la imagen junto con sus pertenencias: ropa -la figura estrena un ajuar completo casi todos los días del año-, objetos personales, juguetes y otros elementos se cambian a la casa del nuevo mayordomo. El 30 de abril, día del Niño, se organiza una kermés entre los vecinos para festejarlo y éste pueda convivir con los pequeños. El Jueves de Corpus Christi la imagen es presentada en el templo vestida con camisa y calzón blanco de manta, a la usanza indígena, recordando los tiempos de evangelización en la Nueva España. Los domingos siguientes el Niño permanece en casa del custodio para la visita de los fieles. A las 6:00 p.m. lo llevan a misa a la Catedral de Xochimilco, más tarde regresa para el rezo cotidiano. Durante el ciclo navideño, del 16 de diciembre al 2 de febrero, los festejos cobran mayor importancia entre los devotos.

\section{DESARROLLO DE LA FIESTA}

Entre cohetes, música y flores, la verbena inicia a las 8:00 de la mañana. Los hospederos recogen a la escultura, ataviada con su ropón nuevo, en casa del mayordomo. El Niño es trasladado al hogar de los primeros en procesión. Una banda de viento entona melodías para el baile de los chinelos -danza nativa del estado de Morelos-, algunos devotos llevan arreglos florales, velas y globos. Al llegar el Niñopan a casa del hospedero, se reparte entre los invitados el típico desayuno de atole y tamales bendecidos por la escultura. Al mediodía, se lleva al Niño al templo para la celebración de la liturgia. Terminada la misa, ya de retorno en casa del hospedero, se comparte entre los cientos de asistentes -invitados o no invitados- la comida a base de típicos platillos mexicanos como el mole o las carnitas de cerdo. El tiempo del festejo transcurre entre música de banda o mariachi, rezos, peticiones y agradecimientos de los fieles. A las 7:00 de la noche, la imagen regresa a casa del mayordomo. Durante el recorrido efectuado del hogar del hospedero al del mayordomo, los convidados se encargan de iluminar el camino con velas, luces de bengala y la quema de todo tipo de fuegos artificiales. Arreglos florales, globos de colores, la música junto con la 
danza de los chinelos entre otros elementos le dan un aspecto particular a la procesión. Ya dispuesto el Niño en el altar fabricado en el hogar del mayordomo, comienza el rezo a las 8:00 p.m.

La fiesta tiene el mismo desenvolvimiento casi todos los días; sin embargo, la verbena aviva las emociones durante el período decembrino, ciclo importante entre los católicos. El ciclo navideño tiene como objetivo recordar el pasaje bíblico del nacimiento de Jesús, hijo del Dios creador del Mundo. Las posadas, realizadas del día 16 al 24 de diciembre, se efectúan de la misma manera antes descrita pero con una variante: niños disfrazados de pastores, la Virgen María, San José y hasta el burrito se suman durante este periodo. La ornamentación de la casa del mayordomo, así como la del posadero, es conforme a la temporada: árboles navideños, plantas de Nochebuena, guirnaldas de color verde, el musgo y el heno sirven para decorar los hogares. Los juegos pirotécnicos se queman al por mayor, el olor a pólvora invade el espacio, se respira y se siente un ambiente diferente al de todos los días y es precisamente por la remembranza de la llegada del Mesías al Mundo. En las calles cercanas a la casa del mayordomo se cuelgan los adornos de temporada (piñatas, faroles de papel, arreglos con flores de la época...) y en la puerta del hogar del custodio se coloca un arco decorado con motivos navideños o florales. Por su parte, las autoridades delegacionales colaboran con mejoras en la pavimentación, el alumbrado, el drenaje o la seguridad entre otras tareas, buscando la armonía del festejo.

La pirotecnia, como ya hemos apuntado, tiene un papel importante en la celebración. Desde muy de madrugada y, a lo largo de todo el día, salvas de cohetes se escuchan. En el recorrido nocturno, las luces de bengala junto con las bombas (cartuchos con una gran cantidad de pólvora que se revienta en el cielo) iluminan y dan calor a la negra y fría noche. Los fuegos artificiales (como las ruedas con sus múltiples colores y figuras) y los castillos (estructuras con formas religiosas, de animales o simplemente con motivos navideños) originan un sentimiento de alegría.

Durante la media noche del 24 de diciembre, los mayordomos en procesión junto con los feligreses se encargan de arrullar al Niñopan hasta la Catedral de Xochimilco. El pueblo ha conservado la tradición de acunar en conjunto a sus imágenes. A lo largo de la calle, se alistan las parejas de personas en fila con su Niño Dios, el cual se encuentra desnudo o con camisón, se le envuelve en una sabanita y se le comienzan a entonar canciones de cuna para dormirlo. Al llegar al atrio de la Catedral, se queman los fuegos artificiales con motivos a la celebración de la Natividad de Jesús.

Instalado en el pesebre, elaborado antes por la familia del custodio, inicia la liturgia. Este pesebre, nacimiento o belén, como se le denomina, es la recreación, con esculturas de yeso, del pasaje bíblico sobre el natalicio del Niño Dios. Es así como podemos encontrar a la Sagrada Familia, en ocasiones de tamaño natural, a los Reyes Magos, los pastores y los animales.

A partir del día 25 de diciembre -día de la Natividad- hasta el día 2 de febrero

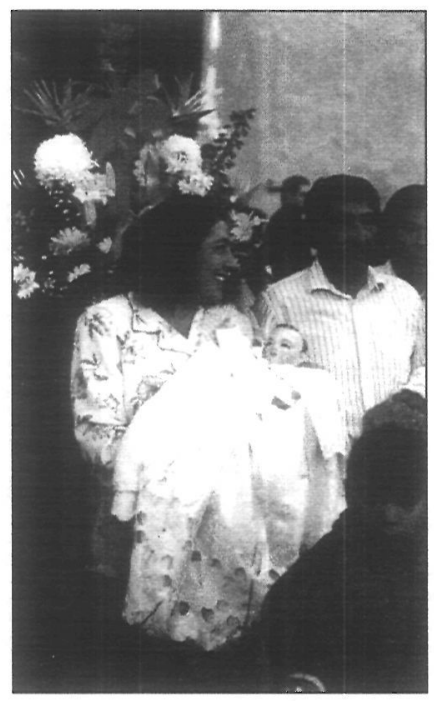

Presentación del Niñopan en el templo. - día de la Candelaria-, la imagen permanecerá recostada en el belén dentro de las horas laborales del templo, es decir, la fiesta se guarda durante 40 días.

Para concluir con el ciclo navideño, el día 6 de enero se recuerda la Epifanía de Jesús niño. El Niñopan, recorre nuevamente en procesión las calles principales de la delegación. A las 4:00 p.m., de casa del mayordomo a la Catedral, los chicos disfrazados de San José, la Virgen María, Melchor, Gaspar, Baltasar y los pastores, acompañan a los fieles a rendir culto a la imagen tan venerada. También se pueden ver algunos regalos que ofrecerán los creyentes a la imagen en el templo.

Dentro de la Catedral, el Niño en brazos de la mayordoma, su madre, junto con los personajes disfrazados, observan el baile preparado por los pequeños pastores y los fieles le entregan sus obsequios. Más tarde, se oficia la misa y se regresa al hogar del custodio en procesión. Para cerrar el ciclo navideño, se comparte entre los feligreses el pan de la grandísima Rosca de Reyes.

Una vez más, el día 2 de febrero, al escuchar las campanadas en la Catedral de Xochimilco, las señoras corren por las calles con sus canastas llenas de semillas de maíz, candelas y sus esculturas de Jesús niño. Durante la celebración de la misa, el nuevo mayordomo espera con ansia tener entre sus brazos la figura del Niñopan y así dar comienzo a su enmienda, dar continuidad al rito.

\section{FIESTA REPRESENTACIONAL}

Gabriel Weisz denomina «estructuras representacionales» a las actividades miméticas innatas que poseen el ser humano y los ani-

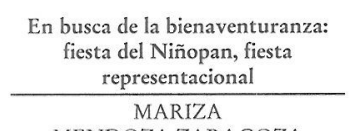

MENDOZA ZARAGOZA 


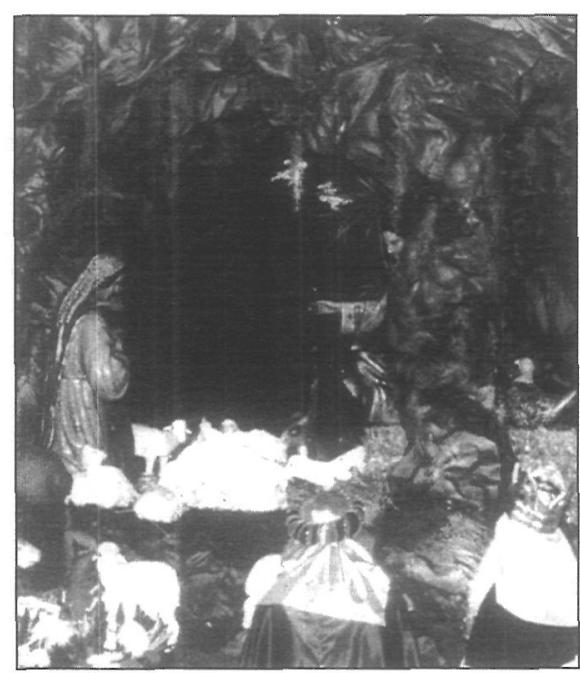

El Niñopan en el Belén.

4

Gabriel Weisz, "El hombre disfrazado", en El juego viviente, México, Siglo XXI editores, 1993, págs. 21-43.

5

Ibidem, pág. 42.

6

Algo que manifiesta lo sagrado, en este caso es la imagen del Niñopan.

7

Mircea Eliade, Tratado de historia de las Religiones, México, Ediciones Era, S.A., 1986, pág. 329.

En busca de la bienaventuranza: fiesta del Niñopan, fiesta representacional MARIZA MENDOZA ZARAGOZA males dentro del área del juego y del rito ${ }^{4}$. La mimesis, arte de imitar o remedar, es parte sustancial de la naturaleza humana. A través de ella, nos convertimos en personajes animales o de alta jerarquía, roles que cambian nuestra conducta. A esta modificación del comportamiento el autor la denomina «estado de posesión»; durante la acción, el integrante ritual se asimila con un período, área y un proceder diferente al cotidiano. Para Weisz el nexo entre el teatro y lo representacional no son los recursos de la narración, del espacio o del tiempo, sino el ejercicio lúdico, «el juego de posesión» de distintos personajes en la celebración: «en el eje de la actividad lúdica-sacra encontramos características cíclicas y ritmos biológicos aunados al movimiento y la alteración de la conducta» ${ }^{5}$.

La búsqueda del equilibrio entre la deidad y sus feligreses impregna a la celebración del Niñopan de estructuras representacionales que llevan al partícipe a procesos subjetivos, lo internan en el campo de la reflexión que tal vez lo guíe hasta un estado de renovación. Por su parte, la música, la danza, así como la mezcla de olores y sabores, alteran los sentidos del partícipe para hacerlo penetrar en el área sagrada. Estos elementos le propician un ambiente de negación a la vida ordinaria y le permiten explorar las fuerzas internas que lo conforman como ser humano dentro de un lapso festivo.

A través del ritual, la creatividad se desarrolla en busca del restablecimiento de lo sagrado. En el espacio sacro se desarrollan los cantos, los bailes y juega un papel importante la ornamentación dedicada a la deidad. $\mathrm{La}$ incursión al terreno implica un proceder peculiar, existe el involucramiento de la subjetividad humana. El tiempo extraordinario, separación de la vida rutinaria, es el momento preciso para que el ser humano se asimile como parte fundamental dentro de la comunidad. El plan maestro es el plano general donde concurren mitos, ritos y juegos. El juego sagrado se determina por el manejo del espacio y del tiempo junto con el lenguaje. Es el patrón de conducta que nos ubica en la realización de la ceremonia.

Los objetos rituales son preñados de señales significativas para los participantes, poseen un valor subjetivo que traspasa los límites de la celebración. Respecto al juguete sacro, éste captura el motivo cosmogónico del festejo, está rodeado de símbolos que manifiestan el pensamiento mágico de la congregación. Dicho elemento mantiene la relación sensorial con el partícipe del ritual, lo atrae y lo atemoriza al mismo tiempo, permitiendo de esta forma la prolongación.

Las «estructuras representacionales» propuestas por Weisz sugieren una analogía con el quehacer escénico. El «estado de posesión», estructura donde los partícipes modifican. su conducta durante la fiesta, es similar a la interpretación de un personaje hecha por el actor en el teatro.

\section{EL TIEMPO Y EL ESPACIO REPRE- SENTACIONAL EN LA FIESTA DEL NIÑOPAN}

La verbena del Niñopan ocasiona cambios espaciales en toda la delegación de Xochimilco. Se comienza con la casa del nuevo mayordomo, la cual se vuelve un recinto sagrado del que emanan fuerzas benéficas para los creyentes; esto es debido a la presencia divina de la escultura. De acuerdo con Mircea Eliade:

La noción de espacio sagrado implica la idea de repetición de la hierofanía ${ }^{6}$ primordial que consagró ese espacio transfigurándolo, singularizándolo, en una palabra, aislándolo del espacio profano que lo rodea [...]. Un espacio sagrado toma su validez de la permanencia de la hierofanía que lo consagró una vez [...]. La hierofanía no tuvo pues como único efecto el de santificar una fracción dada del espacio profano homogéneo; además asegura para el porvenir la perseverancia de esta sacralidad [...]. El lugar se transforma de esta suerte en una fuente inagotable de fuerza y sacralidad que permite al hombre, con la única condición para él de penetrar allí, tomar parte en esa fuerza y comunicarse con esa sacralidad?

El lugar sagrado donde permanece el $\mathrm{Ni}$ ñopan traspasa las cuatro paredes del hogar, es decir, el área ritual trasciende por la fe de los creyentes a todo Xochimilco.

Durante el ciclo Navideño, la comunidad cristiana se traslada a una etapa simbólica. Los cambios elaborados para la bienvenida del Niño fabrican el tiempo y espacio revelados en el mito. Los habitantes buscan instaurar el mítico peregrinaje de la Virgen María y San José por Belén al principio de nuestra era. El intento de revivir el nacimiento de Jesús, invierno tras invierno, cada año mejor 
organizado, es muestra del deseo colectivo de reproducir el período sagrado.

El área sagrada y el tiempo mítico recreado se unen para que la representación efectuada noche a noche sea un verdadero acto de fe, donde el mito vuelve a resurgir para la reconciliación entre Dios y el ser humano. El lugar cotidiano se transforma; en él ocurren las maniobras para llevar a cabo nuevamente el Nacimiento del Mesías, nos ubica una vez más en una coyuntura mágica a través de la participación en la verbena popular del Niñopan. Pero además, el espacio y el período sagrados originan los demás elementos representacionales, como el juguete sacro o los objetos rituales.

\section{EL JUGUETE SACRO, LA IMAGEN DEL NIÑOPAN}

El ser humano ha manifestado el sentimiento de lo sagrado que habita en él de distintas formas, ya sea mediante objetos, personas o rituales, atribuyéndoles un poder divino capaz de transmitir amor y terror al mismo tiempo.

Con base en la teoría del pensamiento mágico religioso desarrollada por Frazer ${ }^{8}$, en la escultura del Niñopan se funden la magia homeopática -lo semejante produce lo semejante- y la magia contaminante-las cosas que una vez estuvieron en contacto actúan recíprocamente a distancia, aún después de haber perdido todo contacto físico-. El primer tipo de magia se da porque el Niño Dios, «el Salvador», se hace presente en la figura de madera recreando la ternura, la esperanza, la pureza, el amor que un niño vivo despierta en un corazón sensible, de tal manera que el Niñopan ya no sólo es una imagen inanimada sino que es el mismo Jesucristo que se nos presenta en una de sus múltiples formas, según los creyentes. La magia contaminante, por su parte, se da por medio del pensamiento mágico: el poseer alguna de sus prendas u objetos ya usados provocará un bienestar en la persona que los conserve.

Los milagros o sucesos «mágico-religiosos» en torno a la figura han hecho que la devoción de las personas cada día sea más grande, convirtiendo las oraciones y rezos en insuficientes muestras de cariño y fe depositadas en él. Por tal motivo, la fiesta es el medio ideal para estar en contacto con el «Creador del Universo». El Niñopan, como juguete sacro, es parte esencial en la vida de muchos creyentes. Es el nexo entre resolucio- nes humanas y divinas; los pesares se olvidan al tener por unas cuantas horas una escultura tan fantástica, una imagen que para los fieles es un niño de verdad, dador de vida y bienestar espiritual, una criatura capaz de conocer el gozo y el sufrimiento del alma humana.

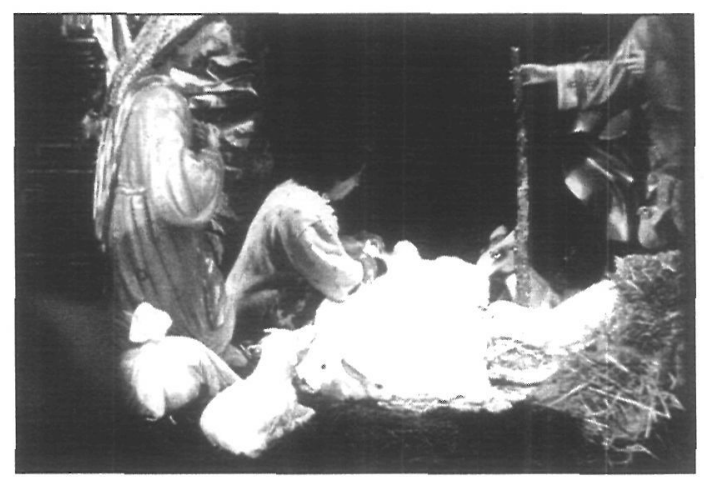

Arrullo del Niñopan en Nochebuena.

\section{EL ESTADO DE POSESIÓN EN LOS MAYORDOMOS}

Durante el año de mayordomía, la vida rutinaria del custodio se ve transformada por un sinfín de situaciones hasta ese momento ajenas a él, situaciones «mágico-religiosas» que cambian su forma de ver, sentir y oler el mundo; así lo explicaba uno de los mayordomos:

Fue algo muy bonito y muy agradable, sobre todo son experiencias que vas teniendo con la gente que viene a visitarlo, gente que viene muy enferma a pedirle con fe por su salud, pero te das cuenta que a veces como humanos somos muy intransigentes y no nos damos cuenta que lo más importante de un ser humano es vivir tranquilamente en armonía, en paz, tener buena salud física [...]. El Niño te trae muchas cosas que no puedes explicarlas, simplemente te trae armonía y felicidad en tu hogar. ¡Se siente!, es algo subjetivo, lo entiendes pero no puedes explicarlo, lo llegas a vivir, a sentir?.

Los mayordomos experimentan, gracias al Niñopan, nuevas alegrías y tal vez penas que los conmueven como integrantes de un rito religioso. La alegría se ve en el rostro de los albaceas al participar en el ritual, «sus propios ritmos internos [...] los llevan al dominio de la representación empleando técnicas de despliegue y simulacro que muchas veces cambian su percepción del mundo» ${ }^{10}$, es una emoción inexplicable que acontece en los devotos de la verbena.

Al interpretar simbólicamente el rol de la Virgen María y San José, los mayordomos «se entregan -diríamos a partir de la teoría de Weisz- a un acto de comunión orgánica. Su cuerpo se dispone a sentir la presencia del dios; el cuerpo es el escenario sensorial donde el dios-modelo puede activarse» ${ }^{11}$. El «estado de posesión», al ser asumido por el matrimonio se da de manera lúdica. El mismo acto
8

James Frazer, La rama dorada, México, FCE, 1982, págs. 34-35.

9

Recogido en Edgar Tavares López, "Religión y magia en los barrios de Xochimilco», Crónicas de la Ciudad de México, año 2, núm. 7, octubre-diciembre 1997, págs. 5-6.

10

Gabriel Weisz, op.cit., pág. 10. 11

Ibidem, pág. 30.
En busca de la bienaventuranza: fiesta del Niñopan, fiesta representacional MARIZA MENDOZA ZARAGOZA 
ceremonial los introduce al plano representacional, juego donde el tiempo, el espacio, los olores junto con los sonidos y las actividades son la causa del cambio de comportamiento de los custodios, así como de los demás integrantes del ritual que están en busca de un beneficio común.

Gracias a la entrega afectiva en la celebración, el estado de posesión funciona como la encarnación del personaje mítico en el creyente. Durante la fiesta del Niñopan, los custodios personifican a los padres del niño Jesús y los demás integrantes sienten la presencia divina recreada en la escultura de madera; por lo tanto, se entregan a la veneración de una figura viva.

Para conformar el ritual diario, los mayordomos necesitan de más elementos. Bajo su supervisión, se encuentra un conjunto humano que los ayudarán a ornamentar la verbena, haciéndola más placentera para la escultura y para sus invitados, sobre todo durante las fiestas navideñas.

\section{LA DANZA DE LOS CHINELOS, LA MÚSICA Y LA PIROTECNIA}

Dentro del espacio representacional del festejo del Niñopan se encuentran inmersos varios objetos rituales como la danza, la música y la pirotecnia, sólo por mencionar algunos.

Personajes disfrazados abundan en la fiesta, lo mismo que los danzantes enmascarados. La danza de los chinelos, se integró hace años como parte importante de la verbena. Su singular baile aprisionó la atención de los habitantes de Xochimilco, las agrupaciones o comparsas de estos danzantes a lo largo del tiempo han proliferado en la entidad.

La creación de la comparsa de chinelos es un requerimiento más que los mayordomos han integrado dentro de sus obligaciones para acompañar al Niño en sus procesiones diarias. Gracias a la magia de la máscara y el disfraz, jóvenes y adultos, hombres y mujeres se confunden en el baile. La fascinación por el trasvestismo que acontece en el danzante no sólo es superficial: la música lo envuelve y lo transforma, penetra en la subjetividad del individuo para hacerlo cumplir su manda, para introducirlo al área representacional.

El trasvestismo es una estructura representacional más que se desarrolla en el ritual del Niñopan. El disfraz permite al ser humano modificar su apariencia y su conducta por unos momentos. "Los chinelos», hombres, mujeres y niños disfrazados con vestidos «femeninos» y máscaras masculinas, ocultan su identidad pero, sobre todo, su sexualidad a lo largo del baile. El trasvestismo recurre a este ejercicio. Que el hombre se disfrace con atuendos de doncellas y la mujer utilice máscaras varoniles. A fin de cuentas es un elemento más de la fascinación de vivir la fiesta representacional.

El baile y la música desde siempre han acentuado la espectacularidad de los festejos. La danza de los chinelos se ha convertido en parte esencial para el divertimento de la fiesta; los danzantes acompañan al Niño en sus recorridos, le abren paso y alegran su camino con el anonimato de su personaje. Los danzantes le bailan a la figura para liberarse de una carga emocional llena de culpas y alegrías que el Niño habrá de aliviar o de perpetuar. La devoción es el motivo que mueve al chinelo en Xochimilco. Los movimientos ejecutados por el danzante modifican el estado anímico, de un comportamiento tranquilo cambia a un porte enérgico, de mayor vivacidad, de presencia, de asimilación en su presente. El chinelo trasmite alegría.

Los bailes han servido como vía de comunicación para aquellos que han encontrado en su fe la respuesta a diversos problemas humanos, es por ello que el bailoteo es una muestra de súplica o agradecimiento a sus peticiones. Así, la danza es un elemento visual-sonoro de gran importancia dentro del comportamiento representacional. «El estado de posesión» que impera durante la fiesta entre los disfrazados, los danzantes, los custodios y los participantes en general, es el resultado de la fe que se le profesa a la figura del Niñopan.

Por su parte, la tradicional música de mariachi o de banda para amenizar es sin duda un elemento representativo en la celebración. Desde los cascabeles y panderos de los pastores hasta los sonidos de los platillos del conjunto musical, sin pasar por alto el ruido de las campanas y las canciones que acompañan al Niñopan, el espacio se ve modificado en una representación religiosa sonante, visual e itinerante que altera el estado emotivo de los participantes.

La música, al igual que la danza, ha servido como un medio de comunicación entre el ser humano y sus dioses. Es por eso que sonidos religiosos o cantos dedicados a las divinidades son plegarias en busca de la ayuda para el bienestar individual o de una comunidad entera. 
Y por último, es difícil concebir una celebración mexicana sin comida y juegos pirotécnicos, mucho menos la efectuada para Dios. Desde la madrugada del día de la fiesta del Niñopan hasta el anochecer, durante los nueve días de las posadas, el silbido de los cohetes se escucha por toda la demarcación como llamadas de atención al magno acontecimiento.

\section{CONCLUSIONES}

Preservar las fiestas y tradiciones de comunidades como Xochimilco en la Ciudad de México, donde la tecnología amenaza con el olvido de estas actividades, resulta importante para recuperar el valor simbólico y emotivo del ritual dentro de una comunidad religiosa.

La organización en la verbena conlleva que las acciones humanas repercutan en el destino de la comunidad, es decir, si la celebración resulta agradable a la divinidad, ésta habrá de otorgar bienaventuranzas a la humanidad y así lograr un buen destino para todos. Es por ello que la teoría representacional desarrollada por Gabriel Weisz resulta significativa para la comprensión de la actividad mimética efectuada dentro de los juegos y rituales. Acercarse a la fiesta del Niñopan permite comprender que el teatro es parte de nuestra vida y el ritual nuestra esencia.
Agradezco infinitamente a todas las personas que me abrieron las puertas de su hogar, y de su corazón, para la realización del reporte de esta fiesta.

\section{FUENTES BIBLIOGRÁFICAS}

Eliade, Mircea, Tratado de bistoria de las religiones, México, Ediciones Era, S.A., 1986.

Frazer, James, La rama dorada, México, FCE, 1982.

Weisz, Gabriel, El juego viviente, México, S. XXI editores, 1993.

\section{FUENTES HEMEROGRÁFICAS}

Cordero, Rodolfo, «El niño padre de Xochimilco», Artes de México, núm. 20, México, verano 1993.

Tavares López, Edgar, «Religión y magia en los barrios de Xochimilco», Crónicas de la ciudad de México, año 2, núm. 7, México, octubre/diciembre 1997.

\section{ARCHIVO}

Archivo General de la Nación, Vínculos y mayorazgos, ff. $8 \mathrm{f}-8 \mathrm{v}, 9 \mathrm{f}, 15 \mathrm{f}-15 \mathrm{v}$, vol. 279 , exp. 1 . 


\section{Ileana Azor}

Investigadora Titular por la Academia de Ciencias de Cuba y Doctora en Ciencias sobre Arte. Ha sido profesora en el Instituto Superior de Arte de la Habana y ha dictado conferencias en universidades $\mathrm{e}$ instituciones culturales de Estados Unidos, España, Rusia, Argentina, Alemania, Venezuela, Puerto Rico y México. Pertenece al Sistema Nacional de Investigadores de México. Ha publicado tres libros de ensayos (entre los que se encuentra Teatralidades y carnaval. Danzantes y color en Puebla de los Ángeles, Gestos, 2004) y seis antologías críticas y de obras teatrales relacionadas con el teatro latinoamericano. Numerosos ensayos suyos han aparecido en revistas especializadas de Europa, Estados Unidos y América Latina. Actualmente es profesora de Tiempo Completo y dirige la Licenciatura en Teatro de la Universidad de las Américas-Puebla (México).
Los carnavales en México. Teatralidades de la fiesta popular

\section{LOS CARNAVALES EN MÉXICO. TEATRALIDADES DE LA FIESTA POPULAR}

\author{
ILEANA AZOR
}

\section{RESUMEN}

Desde mucho antes de la «era posmoderna», los que nos autodenominamos o dejamos que nos ubiquen como occidentales arribamos a la convicción de que las verdades absolutas y las respuestas totalizadoras no existen. Las manifestaciones artísticas, por su parte, han sido siempre un buen antídoto para la mirada única y definitiva. Por lo tanto, fiel a esta historia, propongo un acercamiento metodológico a las fiestas populares mexicanas y específicamente a los carnavales desde perspectivas provenientes de la antropología, la etnoesecenología y la teatralidad.

Partiremos de un vasto y rico corpus que se estimaba hace cerca de 10 años en más de 5000 fiestas. Por ello haré una caracterización central del problema teórico-metodológico y esto me permitirá aplicarlo a algunos carnavales de varios estados de la república, entre los que se encuentran los rurales y urbanos de Puebla de los Ángeles. Santiago Xalitzintla, Huejotzingo y San Nicolás de los Ranchos son las comunidades rurales en las que se centrará el análisis y los barrios antiguos de la ciudad de Puebla serán las otras fuentes. En ellos veremos los rasgos generales, así como las similitudes y las divergencias en la concepción misma de una teatralidad que se define desde su origen histórico y se ha ido modificando a partir de su función social y religiosa, las condiciones topográficas y las de incorporación comunitaria a la festividad.

\section{CARNIVALS IN MEXICO: POPULAR CELEBRATION DRAMA}

\section{ABSTRACT}

Much before the 'postmodern era', those of us who call ourselves or let ourselves be called western came to the conclusion that absolute trutbs and totalising responses do not exist. For their part, artistic performances have always been a good antidote to the unique and defining gaze. Thus, so as to be truthful to this history a methodological approach to popular Mexican celebrations is proposed with specific emphasis on carnivals via anthropological, ethnoscenological and dramatic perspectives.

The vast and rich corpus estimated at over 5,000 celebrations some 10 years ago shall be used as a basis. A central characterisation of the theoretical-methodological problem will be carried out so as to be applied to carnivals from various states around the country including both rural and urban ones in Puebla de los Angeles. Santiago Xalitzintla, Huejotzingo and San Nicolas de los Ranchos are the rural communities upon which the analysis is focused, with the old quarters of the city of Puebla also serving as source material. The general features will be observed as well as the similarities and differences in the very conception of drama, as considered from its historical origins and having undergone changes based on social and religious function, topographic conditions, and circumstances concerning community involvement in the celebration. 
La comunicación ritual es la que tienen los participantes con ellos mismos a través de un texto que da forma y fijeza, sí, a las acciones rituales, pero que es plural y ambiguo, situacional y abierto al cambio, a diversas interpretaciones en competencia y a la crítica ${ }^{1}$.

Por lo menos en México, las danzas religiosas siguen vivas porque persisten las condiciones que justifican su existencia, esto es, la función de significar y explicar por medio de los códigos que le son propios la relación entre el hombre y la realidad que necesita ser comprendida?2.

La «ambigüedad fronteriza» ${ }^{3}$ que subyace en la esencia de muchas de las celebraciones populares mexicanas es un reto epistemológico para cualquier investigador interesado en lograr un acercamiento no ortodoxo al tema. Objeto casi siempre de estudios antropológicos, la presencia representacional y sus nexos con la vida cotidiana, que involucran un sinnúmero de fenómenos -rituales, lúdicos, teatrales-, se han convertido, al menos en los últimos veinte años, en el centro de atención de especialistas de diversos campos de la teoría o de la ensayística artística y teatral ${ }^{4}$.

Desde fines de los noventa, comenzamos a explorar algunas manifestaciones de la fiesta popular mexicana -la Semana Santa en San Miguel de Allende y San Pedro Cholula, el Día de Muertos en Huaquechula-, como continuidad de una inquietud anterior por estudiar la vinculación entre rito y teatro en expresiones de la escena cubana contemporánea.

El recorrido nos llevó a visitar distintas comunidades del estado de Puebla, donde la realización de unos asombrosos carnavales tenían lugar cada año entre los meses de febrero y abril. Observar una y otra vez estos fascinantes fenómenos, buscar información sobre componentes, formas organizativas y maneras de participación en conversaciones con sus protagonistras e intercamnbiar con colegas de otras especialidades como un antropólogo $0^{5}$ dos investigadores ${ }^{6}$ y un fotógra$\mathrm{fo}^{7}$ especializado en expresiones de la cultura popular mexicana, fue parte de un intenso proceso de búsqueda que conllevó, al mismo tiempo, la exploración teórico-metodológica más apropiada para tal corpus.

En este camino, dos definiciones se nos hicieron imprescindibles: los conceptos fiesta y teatralidad.

Más allá de las interferencias con otros como juego y rito, la fiesta, presente sobre todo en la bilbiografía antropológica, nos resultaba más cercana a la naturaleza de estas celebra-

ciones, que involucran factores religiosos, políticos, sociales, étnicos, económicos, espectaculares y antropológicos. Verificamos que para todos ellos lo festivo formaba parte de la riqueza cultural de la comunidad, evidenciando su capacidad para propiciar espacios de comunicación, consumo no productivo y de ruptura

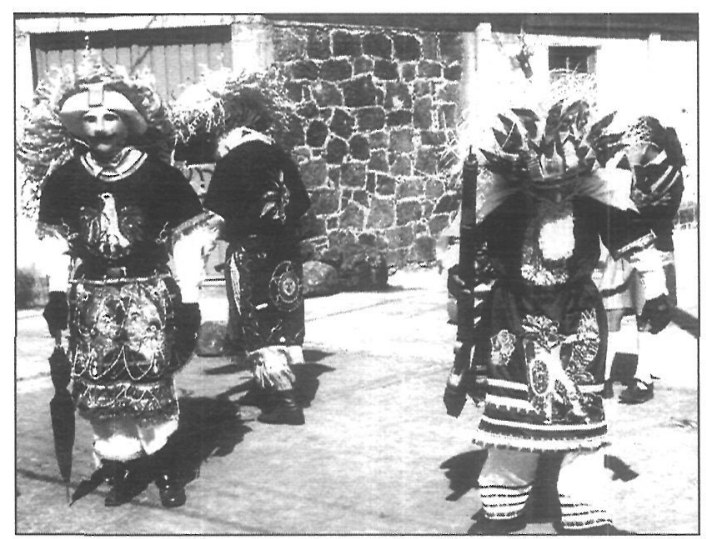

Danzantes del Carnaval en la región de Puebla. con la obligación, don-

de el despliegue de la energía grupal estaba encaminado a buscar un tiempo de libertad, celebración y autorreconocimiento.

Las posturas más extendidas han sido las que relacionaban las fiestas con actos de transgresión (Freud, Bajtin, Girard, Bataille, Paz), ruptura de la vida común, trastorno y desborde de la cotidianeidad (Bajtin, Duvignaud, Callois, Durkheim), exceso y derroche (Bajtin, Mauss) o indiferenciación e indeterminación (Duvignaud, Michelet, Durkheim, Callois). Mijail Bajtin, por ejemplo, afirma en su estudio sobre la cultura en la Edad Media: «...las fiestas, en todas sus fases históricas, han estado ligadas a periodos de crisis, de trastorno, en la vida de la naturaleza, la sociedad y del hombre»8; y de esta forma confluye en una gran línea de estudios que tienden a ver en la fiesta una ruptura total con el mundo cotidiano. La inversión sígnica es fuente de liberación de las fuerzas reprimidas, las reglas, los estatutos y las normas. Así, observamos la fiesta como una suerte de marcaje que nos permite sentir que se concluye algo, y se comienza de nuevo; porque de igual manera ésta es una cadena que volverá a repetirse una y otra vez.

En este sentido, coincidimos con Velázquez Mejía cuando nos presenta la fiesta como una forma metafórica de vivir la cotidianeidad, la cual ve tensionados y dirigidos hacia un nuevo sentido sus mismos elementos. Por eso, es congruente cuando plantea que la fiesta es una celebración que nos habla de una historia con una fuerte división sociocultural, lo cual se observa en la morfología de los distintos momentos festivos, que muchas veces muestran la diferenciación de oficios y labores dentro de una zona?

Nacida con el siglo XX, la teatralidad, como concepto, para varios teóricos resume una relación específica con la realidad: a la vez
1 Rodrigo Díaz Cruz, Archipiélago de rituales. Teorías antropológicas del ritual, Barcelona, Anthropos, 1998, págs. 293-294.

2

Carlo Bonfiglioli, Fariseos y matachines en la Sierra Tarahumara: entre la Pasión de Cristo, la transgresión cómico-sexual y las danzas de Conquista, México, INI, 1995, pág. 31.

3

lleana Azor, Teatralidades y carnaval. Danzantes y color en Puebla de los Ángeles, California, Gestos, 2004, pág. 19.

4.

Algunos son representantes del posestructuralismo como Jacques Derridá, del poscolonialismo como Homi Bhabha, de la estética como Nicolas Bourriaud o más cercanos al teatro como Patrice Pavis, Josette Féral, Juan Villegas, Erika Fischer-Lichte, Helga Finter y Jorge Dubatti, entre otros.

5

El Dr. Timothy Knab.

6

La Dra. Alma Yolanda Castillo y el Dr. Joel Dávila.

7

El Maestro Rolf Seul.

8

Mijail Bajtin, La culfura popular en la Edad Media y el Renacimiento, Madrid, Alianza Editorial, 2003, pág. 14.

9

Arturo Velázquez Mejía, La fiesta: espacio, manifestación y comunicación de cotidianeidad histórica, Estado de México, UAEM, 1984.

Los carnavales en México. Teatralidades de la fiesta popular ILEANA AZOR 


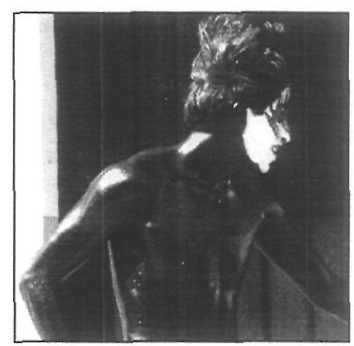

"Judío» negro en el Carnaval de San Nicolás de los Ranchos.

10

Ragnhild Tronstad, «Theatricality and Metaphorical Structures», Substance, 2002, vol. 31, núm. 2\&3, pág. 223.

11

Marvin Carlson, "The Resistance of Theatricality», Substance, 2002, vol. 31, núm. 2\&3, pág. 249.

\section{2}

Cirado por Janelle Reinelt, «Performativity meets Theatricality", Substance, 2002, vol. 31, núm. 283, pág. 358.

13

Claude Gaignebet y MarieClaude Florentin, El Carnaval. Ensayos de mitología popular, Barcelona, Editorial Alta Fulla, 1984, pág. 106

14

Arnold Van Gennep, Le folklore français, Paris, Robert Laffont, 1999.

15

Josefina Roma Riu, Aragón y el carnaval, Zaragoza, Guara Editorial, 1980, pág. 90.

16

Bonfiglioli, op. cit., pág. 25.

Los carnavales en México. Teatralidades de la fiesta popular ILEANA AZOR diferente y similar. «Thus, for theatricality to exist, the world cannot become mere theater, just as the theater can never become mere reality. But as long as we have both spaces -the 'real' space and the fictional space- theatricality may occur» ${ }^{10}$. Marvin Carlson enfoca su opinión de esta manera:

Theatricality, viewed from this perspective, can admit to all those qualities that have historically been cited against it -that it is artificial, removed from everyday life, exaggerated, extreme, flamboyant, distracting. Yet despite-indeed because of- these qualities, it can still be recognized as an essential element in the continued vitality and enjoyment of both theater and performance and beyond that, as a positive, indeed celebrative expression of human potential ${ }^{11}$.

La definición más cercana, sin embargo, es aquella en la que Josete Féral, considera:

Par le regard qu'il porte, le spectateur crée alors face à ce qu'il voit un espace autre dont les lois et les règles ne son plus celles du quotidien et ou il inscrit ce qu'il regarde, le percevant alors d'un oeil différent, avec distance, comme relevant d'une alterité òu il n'a de place que comme regard exterieur ${ }^{12}$.

Las teatralidades asociadas a las fiestas populares mexicanas podrían rastrearse en estudios como los de Gaignebet y Florentin, Roma Riu y Van Gennep, cuando observan «la dramatización» como un fenómeno inherente a todo rito ${ }^{13}$, porque tiene tres partes que lo conforman: una introducción o presentación, un desarrollo que tiene puntos climáticos y una solución o parte final14; y cuando ven en específico al carnaval como un escenario que personifica «la lucha del invierno y la primavera, del bien y el mal, en definitiva de la muerte y la vida»15.

De tal manera pensamos que el concepto teatralidad aplicable, por ejemplo, a las fiestas mexicanas, más que conformar un módulo único y universal, es un instrumento flexible, inclusivo, que podemos conceptualizar como la concreción de estrategias compartidas por productores y receptores, en la elaboración de proyectos de carácter discursivo en constante cambio. Estas construcciones son simbólicas y están históricamente determinadas por grupos culturales, en un espacio dinámico, donde la acción que tiene lugar en ellas, integra esa difuminada y mágica frontera entre lo real y lo soñado que se pone en práctica de manera consciente.
La propuesta del concepto teatralidad, o quizás el de teatralidades, consigna una voluntad teórica abierta frente a las numerosas circunstancias a las cuales debe responder, y pretende lograr una interpretación que, sin desdeñar la importante fase descriptiva del hecho festivo, le aporte una base modular incluyente común que permita crear un marco referencial teórico de características adaptables a su vez a cada variante.

Por teatralidades entendemos, pues, no simplemente actividades humanas expresivas que descubren su parentesco con lo espectacular, aunque una y otra vez los participantes en la mayoría de las fiestas expresan que en ellas «ensayan o ensayaban escenas del teatro», es decir, las relacionan con una representación. En particular, queremos designar con ellas a la creación de una espacialidad ficcional, cuya composición está tensionada y dinamizada por la mirada del otro que a fin de cuentas en estos casos es una prolongación de ellos mismos. La conciencia dual de ser una entidad diferente e igual a si misma los hace ser conscientes de que forman parte de un cosmos que «se mueve» (y esto es importante), en esos días y paulatinamente con el transcurrir de los ciclos, de manera distinta a los demás días del año. Es otro espacio o el mismo, pero pautado y asumido de otra manera, es otro tiempo (dilatado, casi interminable, fuera de la concepción vertiginosa y cambiante de lo rutinario) y es otro rol (distinguido, enmascarado, orgulloso de su nueva identidad). Estos elementos construyen una secuencialidad aparentemente caótica que el visitante ajeno a los acontecimientos percibe distanciado, pero conmovido, como si una cápsula trascendente envolviera esta metarrealidad.

Pero, además, muchas de las fiestas populares mexicanas están asociadas a la danza, expresión abstracta, actividad simbólica de nuestro cerebro que permite la exteriorización de la memoria individual, pero al mismo tiempo la comunicación colectiva con el cosmos, la naturaleza, los seres míticos y actuales $^{16}$.

El carnaval mexicano es un mosaico danzario, de manera que, si intentáramos catalogarlo, podríamos constatar no menos de veinte expresiones en las veintiocho entidades de la república donde sabemos que se celebra. Así, se ejecutan desde los clásicos y poco codificados bailes de disfraces, en los que pueden incorporarse danzas europeas de salón, o los desfiles de comparsas, hasta algunos bailes más acotados como el de Los huehuen- 
ches, Los Casquetes, El Torito, Los Catrines, Las Cihuames, La Culebra, El Tlaxcalteco, Las Cintas, Las Chirrioneras, El Jarabe, Los Chinelos (o Danza de los Aztecas), El Salto, Los Tejorones, el Baile de la Harina, El Tutuguri-Yúmari, la Danza de los Arcos, el de la Jarana o Vaquería, Las Ahkot (danza entre mujeres jóvenes de Bachajón), el del Tigre y el Mono, el del Corte de Gallo, El Pochó y Los Blanquitos. Aunque muchas de ellas se ejecutan en varios estados del país, coincido con Bonfiglioli en que

...no hay danza que se repita dos veces de la misma manera...Todas son portadoras de una pequeñísima innovación estética, un paso o un gesto determinado, una prenda del vestuario que, voluntaria 0 accidentalmente, aparece y desaparece del escenario dancístico ${ }^{17}$.

Por ello, no es sorprendente que aparezcan, por ejemplo, variantes de las Danzas de Conquista en muchas de las localidades y a lo largo del calendario ritual, y no pocas estén asociadas al carnaval, donde en varias poblaciones se producen bailes en los que dos bandos se enfrentan, provocando una alteración del «orden» para después recuperarlo.

En las bases del carnaval europeo ya estaban estos trazos de cambio, inversión y batalla a nivel cosmogónico. Josefina Roma Riu enumera cuatro características fundamentales que se ponen de manifiesto en el carnaval:

$\left.1^{\circ}\right)$ La celebración del final del invierno y recomienzo del ciclo productor de la naturaleza y del hombre. Lo cual requiere un conocimiento cósmico y del entorno que consiga interpretar los menores signos de cambio como inicio de la nueva estación.

$2^{\circ}$ ) Una interacción entre el mundo tangible y el mundo del Más Allá. Los muertos y antepasados tienen también su intervención en la marcha del mundo de los vivos.

$3^{\circ}$ ) Este paso importante requiere una purificación individual y colectiva.

$4^{\circ}$ ) La fiesta es en sí misma la inversión del tiempo cotidiano. Su materialización se dará en el disfraz, en el cambio de papeles, en la crítica no castigada del poder, en una liberación de la represión sexual. En una comida abundante y en un ensalzamiento reversible de los sectores menos favorecidos de la sociedad, la mujer, los niños, los pobres...»18.

En definitiva es un conjunto de ceremonias cuyo simbolismo se conjugará para obtener su fin primordial, esto es, asegurarse la continuidad de la vida en una época cósmica peligrosa, la más peligrosa del año. El carnaval trata así

...de ritualizar el momento más importante del año (...). Su importancia está en la batalla entre la muerte y la vida. La necesidad

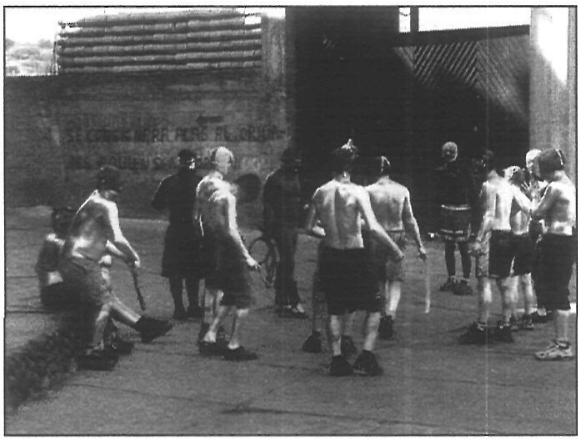

Cuadrilla de «judíos» en el Carnaval de San Nicolás de los Ranchos. de asegurar la fertilidad del mundo y el tránsito de los difuntos sobre la tierra que deben ser enviados al mundo superior, desde donde se asociarán a la tarea fertilizante de campos, animales y personas. Lograr este tránsito de seres malévolos a seres fertilizantes, lograr que la muerte se convierta en resurrección, requiere la totalidad de fuerzas humanas y sobrehumanas y la concentración de los rituales mayores de todo el año ${ }^{19}$.

Ritos de fertilidad en la vida vida griega y romana antigua están en el sustrato originario del carnaval, que siguió su curso a través de la Edad Media, ya contaminado con la religiosidad cristiana. Bien conocidos son los estudios de Mijail Bajtín y Julio Caro Baroja sobre el tema ${ }^{20}$ y poco precisas las informaciones de la llegada de estas celebraciones a México, aunque se estima que se produjo a partir del siglo XVI. La fusión, intercambio y diálogo con las festividades prehispánicas de aztecas, toltecas y mayas ha sido fuente de estudios desde principios del siglo $\mathrm{XX}^{21}$.

\section{ROSTROS DEL CARNAVAL EN PUE- BLA DE LOS ÁNGELES}

Ubicada en el centro de la república mexicana, Puebla de los Ángeles está escoltada por cuatro volcanes, once cerros, tiene quince distintos tipos de clima y está dividida en once regiones etnográficas. Con más de cinco millones de habitantes en doscientos diecisiete municipios, en ella se hablan cincuenta y siete lenguas, incluyendo el español ${ }^{22}$.

De una riqueza festiva ritual notable ${ }^{23}$, en nuestra opinión, tiene en sus carnavales una de las celebraciones de mayor relevancia. Por sus características, los hemos dividido en rurales y urbanos, no tanto por tener lugar en poblaciones de menor o mayor grado de desarrollo industrial, sino por la manera de enfrentar la fiesta.

\section{7}

Ibidem, pág. 26.

18

Roma Riu, op. cit., pág. 75.

19

Ibidem, pág. 91.

20

Bajtin, op. cit. Julio Caro Baroja, El carnaval (Análisis históric culfural), Madrid, Taurus, 1965.

21

Higinio Vázquez Santana e lgnacio Santana Garibi, El carnaval, México, Talleres gráficos de la Nación, 1931.

22

Centro Estatal de Información y Documentación de los Pueblos Indígenas del Estado de Puebla, Puebla, Kaltamatiloyan, 2000.

23

Trece danzadramas recoge Ricardo Pérez Quitt en «Teatro prehispánico en Puebla (Cuetzalan y Atlixco)", Máscara, 1993, Año 3, núm. 13-14, póg. 126 También se ejecutan más de nueve danzas en la Sierra Norte y ritos a los volcanes, el Santo Patrono de cada localidad y las del ciclo católico, entre otras.

Los carnavales en México. Teatralidades de la fiesta popular ILEANA AZOR 


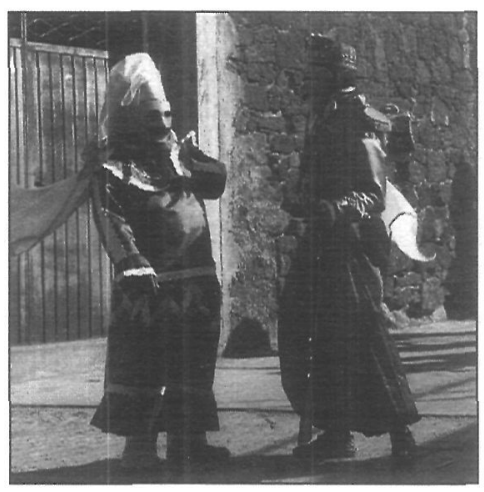

"Huehues» que evocan el 5 de mayo de 1862.

24

Ignacio Cabral, San Miguel de Huejoitzingo, Puebla, Universidad de las Américas, Puebla, 1990, pág. 4.

\section{5}

Susan Verdi Webster, «Art, Ritual, and Confraternities in Sixteenth-Century New Spain", Anales del Instituto de Investigaciones Estéricas, 1997, núm. 70, págs. 12-25.

26

Haydée Quiroz Malca, El carnaval en México abanico de culturas, México, CONACULTA, 2002, págs. $51-52$

\section{7}

Joel Dávila Gutiérrez, Francisco Serrano y Alma Yolanda Castillo Rojas, Guerra al pie de los volcanes. El carnaval de Huejolzingo, Puebla, BUAP, 1996, pág. 18.

Los carnavales en México. Teatralidades de la fiesta popular ILEANA AZOR
Huejotzingo, San Nicolás de los Ranchos y Santiago Xalitzintla son las poblaciones donde la fiesta va a tener connotaciones más complejas, mientras que en los barrios antiguos de la ciudad como Xonaca, El Alto, Lomas 5 de Mayo, San Felipe Hueyotlipan y San Baltasar Campeche se representan con un enfoque más profano.

Desde la concepción misma de la fiesta y su desarrollo en torno a un espacio central que se convierte en círculo de convocatoria comunitaria, hasta el hecho de estar vinculado en muchos casos con una celebración de tipo agrícola, el diseño de la fiesta carnavalesca rural en Puebla va a descansar sobre soportes rituales mucho más precisos e intensos que los urbanos que priorizan el despliegue de colores y formas en el vestuario y la precisión de las coreografías danzarias.

El Carnaval de Huejotzingo es uno de los más conocidos o al menos mencionados dentro de las festividades que, previas a la Cuaresma y la Semana Santa, México celebra. Si bien Puebla no se puede decir que es un estado carnavalero, como si lo es, por ejemplo, Tlaxcala -el investigador Joel Dávila en el 2001 ya tenía registrados setenta- el peso específico de esta festividad dentro de la geografía local y nacional es de mucho prestigio y al mismo tiempo generadora en el visitante de cierta inquietud por lo ruidoso y guerrero de la celebración. Junto a los muy diferentes de Mérida y Veracruz, o los más cercanos de distintos pueblos de Tlaxcala y algunos más en Morelos y Oaxaca, el de Huejotzingo se ha ganado la admiración de cada vez más seguidores que no por ser extraños al lugar -pues está demás decir que en él participan de una u otra forma todos los habitantes del pueblo-, entorpecen el delirio jocoso, travieso y ennoblecedor de la entrega de energía y pasión que los «huejos» derrochan unos días antes del Miércoles de Ceniza.

En el caso del citado carnaval se reúne un pasado guerrero prehispánico que involucraba la tradición de las guerras floridas (propiciatorias de sacrificios), y rituales que celebraban festividades, como las del año agrícola de Tláloc, coincidentes en fechas con las del carnaval europeo. Por otra parte, existían otras expresiones de teatralidad como las celebraciones religiosas cristianas durante la Colonia, relacionadas con uno de los primeros establecimientos franciscanos en la Nueva España: el monasterio de San Mi- guel de Huejotzingo, conjunto monumental formado por el atrio, las capillas posas, el templo y el convento, cuya fundación data de 1524-152524. Entre las manifestaciones de teatralidad, relacionadas con éste último centro religioso, aparecen los casamientos y otras actividades de la liturgia católica, entre las que se encuentran las tempranas procesiones de penitentes en Semana Santa, organizadas por las confraternidades de la Vera Cruz desde el siglo XVI y San Diego en el siglo XVII y las representaciones de la Pasión-Lavatorio o Mandato, Descendimiento y Encuentro-25.

Otro hecho que se involucra en el carnaval es una leyenda que cuenta la historia del rapto de la hija de un alto jefe indígena de Huejotzingo por parte de un bandido de la zona. También a veces el mito se ubica en la etapa de la colonia, con lo cual pasa a ser la hija del corregidor la que es raptada. Esta leyenda se une a la de un héroe que al parecer vivió a mediados del siglo XIX -Agustín Lorenzo-y es recordado en corridos, danzas, leyendas y obras teatrales de los estados de Guerrero, Puebla y Morelos. Amigo de los pobres y enemigo de los ricos ha sido canonizado en pueblos como Xalitla, donde se le conoce como San Agustín Lorenzo ${ }^{26}$.

También se hace referencia de manera muy central a los sucesos históricos de la Guerra de Intervención francesa, especialmente a la batalla del Cinco de Mayo de 1862 y del sitio de Puebla un año después:

Actividades consideradas como típicamente militares se carnavalizaron, apareciendo así las retretas, las tomas de cuartel, los robos de bandera, las honras fúnebres y, sobre todo, los simulacros: juegos de guerra en donde se disparan grandes cantidades de pólvora ${ }^{27}$.

Estas son referencias fundamentales para entender la construcción de una teatralidad que se añade a la tradición propia del carnaval europeo, de por sí complicada por su doble propuesta de celebrar el fin de un ciclo agrario y el principio de otro (la vida y la muerte juntas de nuevo) y dar inicio a los preparativos para la Semana Santa, dando aquella rienda suelta a los excesos de la carne -palabra que está en el origen del término carnaval que designa la fiesta misma- y a todo lo permisivo que se produce durante estos días.

La forma en que los pobladores van diseñando su carnaval van creando una especie de ritual repetitivo que comienza los domingos de enero, en los cuales se producen los 
primeros bailes callejeros y otras actividades en los barrios, según ellos para ir avisando que el Carnaval está cerca y que hay que ir preparándose. Así, se van produciendo variables de sucesos expansivos que abarcan toda la ciudad y ocupan un tiempo aleatorio, disperso y breve. Otro momento tiene lugar cuando poco a poco comienzan a estrechar el cerco hasta reducir la espacialidad a muy pocas calles, que forman un cuadrángulo con una ligera extensión a dos lugares significativos: la Villita y Cerro Gordo, y se concentran en una densificación del tiempo festivo que dramatiza el tiempo real y lo convierte en trascendente.

En San Nicolás de los Ranchos, más cercano al volcán Popocatépetl, organizadores y participantes activos del carnaval nos informan de sus raíces prehispánicas, relacionadas con los sacrificios humanos. Se pintaban el cuerpo como penitencia para favorecer la buena siembra del maíz y el frijol y bailaban para darse gusto. El color negro, que se aplicaban en el cuerpo casi desnudo, provenía del tizne del comal y el rojo, del jugo del nopal; ambas sustancias se adherían a la piel con grasa animal.

En la época de la colonia estas festividades se sincretizaron con las celebraciones del carnaval europeo. Más tarde, con los sucesos del 5 de mayo de 1862 se incorporan las cuadrillas de huehues. Algunos son guerreros como los zacapoaxtlas y franceses, pero también hay charros. Los «judíos» herederos de aquellos danzantes prehispánicos, llevan, como aquellos, el cuerpo casi desnudo y pueden ir pintados de cinco diferentes colores: negro, amarillo, rojo, blanco y plateado, ahora de pintura industrial de aceite. Cada uno simboliza el cultivo que desea proteger. El negro, el frijol ayocote; el amarillo, el frijol de ese color y el maíz; el blanco y el plateado, el maíz blanco y el rojo, el maíz rojo. Llevan armas como atributo de su poder que van desde cadenas y palos, hasta la combinación de ambos y chicotes.

Ambos grupos -las cuadrillas de huehues y los «judíos,» llamados así por la acepción que este término tenía, significando «diablo» en el siglo XVI- desfilan el lunes y el martes de carnaval, alrededor de la plaza, intercambiándose y sin observar una organización por secciones. Otra línea que atraviesa la fiesta es la existencia de un rey, una princesa y dos pretendientes: el rico, que ella desprecia, y el pobre, Agustín Lorenzo, de quién está enamorada.
En Santiago Xalitzintla también hay una tradición que se remonta a la etapa prehispánica y a los ritos vinculados con la «autorización» de la siembra por los enviados del inframundo náhuatl. Recuérdese que estos dieron lugar en el centro de México a las conocidas «guerras floridas, cuyo fin era el de obtener cautivos para sacrificar y alimentar a esos espíritus que representaban y si-

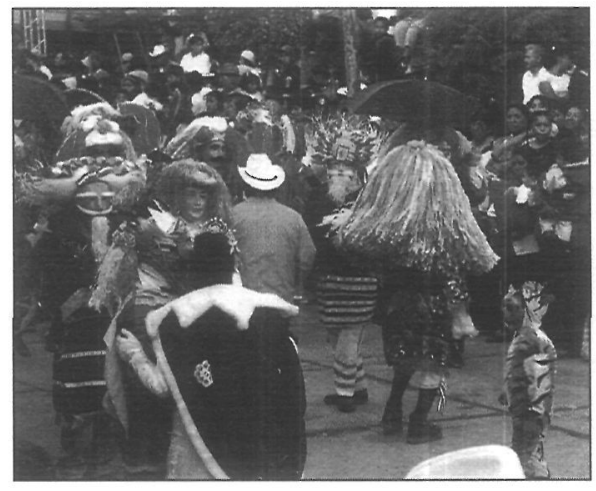

Desarrollo del Carnaval de San Nicolás de los Ranchos guen representando la fertilidad. Esas fuerzas del inframundo simbolizadas por guerreros prehispánicos de Atlixco, Tlaxcala, Cholula y Huejotzingo, hoy se traducen en los carnavales de la región en personajes que «molestan» a la población al tratar de mancharles la piel o la ropa con la pintura industrial de aceite que cubre su cuerpo y que les permite difuminar su identidad cotidiana junto a las máscaras que conforman parte del vestuario y maquillaje de la representación. Hasta que estos enviados del inframundo encarnados en los pobladores de la comunidad, no bailan hasta el cansancio en las fiestas carnavaleras la siembra no se puede efectuar a riesgo de que se malogre.

En San Pedro Cholula, especie de territorio carnavalero intermedio entre lo rural y lo urbano, el despliegue guerrero es el protagonista de la fiesta, pero también incluye como componentes algunas figuras que sobre todo están vivas en los carnavales de los antiguos barrios de Puebla: el diablo y la calavera, hoy casi en extinción en Cholula.

\section{LA CIUDAD Y SUS HECHIZOS}

Como el espacio del carnaval urbano de Puebla radica y tiene lugar en los barrios más antiguos, es necesario caracterizarlos. La vida compartida en comunidad, soporte de varias prácticas culturales, hace del barrio un territorio con una cierta organización temporal y de ocupaciones y es, al mismo tiempo, un lugar donde el grupo se plantea existir con algún sentido humano. El barrio va a desempeñar un factor primordial en la gestación de la fiesta y es por él que aún se mantiene.

El carnaval urbano en Puebla tiene características comunes a los que se celebran en el resto del mundo, especialmente en cuanto a fechas y funciones. Se dice que estos festejos tuvieron su origen en la época colonial. Nació en el barrio de El Alto, gracias a un grupo
Los carnavales en México. Teatralidades de la fiesta popular ILEANA AZOR 


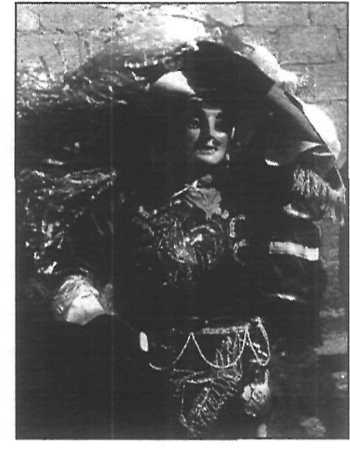

"Huehue» de Carnaval de tlaxcaltecas vendedores de carbón que lo trajeron de su tierra. Se afirma que al principio sólo bailaban los inmigrantes y después se integraron el resto de los vecinos. Por lo tanto, sus vestimentas, música y bailes vienen del fronterizo Estado de Tlaxcala.

Tienen lugar desde el domingo anterior al Miércoles de Ceniza y se prolongan durante lunes y martes. Culminan el domingo siguiente en lo que se conoce como el «remate» o la «octava,» rutina similar a la que se cumple en los otros analizados, pero acá también recibe el nombre de «ahorcada del diablo,» pues éste es uno de los rituales que tiene lugar el martes de carnaval y que se repite como cierre el último día en estas festividades urbanas.

Cada comparsa ha sido conformada por los «encabezados,» cinco o seis responsables máximos de organizarla con un mes o más tiempo de antelación, así como de establecer los ensayos, velar porque se cumpla el recorrido acordado semanas antes, cuidar que se desarrollen los pasos y bailes establecidos y guiarles durante el carnaval. Entre los integrantes están los huehues. Éstas son las figuras más prominentes y representan a los hacendados de la etapa colonial, que encarnan el poder, la fama y la riqueza y hacia quienes se proyecta entre respeto y mofa. Las Maringuillas o Marías que recuerdan a la Malinche, son admiradas por su belleza e inteligencia y hacia ellas se profesan sentimientos encontrados de desprecio y reverencia, pero al mismo tiempo son el corazón de los bailables, convirtiéndose muchas veces en el personaje que juega el papel central de los mismos. Los diablos, representantes del mal, convertidos hoy más en personajes divertidos que hacen travesuras a grandes y a chicos, aparecen entre uno y cuatro en cada comparsa, son a veces interpretados por niños y tienen el último día el papel protagónico, al constituir unos de los eventos principales de los ritos de clausura, cuando se les «castiga» de diferentes formas, que pueden ir desde amarrarlos y golpearlos o hacer parecer que se les golpea y ataca, hasta quemar figuras que los representan. Otros personajes que se han añadido son: la china poblana que lleva antifaz y sombrero y la mujer urbana, que siempre es un hombre transvestido portando una minifalda, con piernas, espalda y brazos velludos al descubierto. También aparece el charro, una variante del huehue, y una serie de figuras que van desapareciendo entre los que están las calaveras, los brujos y los monstruos.
Los recorridos van diseñando un desplazamiento por el entorno urbano que no busca, sin embargo, la concentración espacial observada en los rurales. El centro es la cuadrilla misma que quiere que la vayan siguiendo los observadores y el trazado propone una dinámica de danzas diferentes que buscan la separación y la unión de los danzantes a través de giros, listones y enlaces humanos. Es un carnaval mucho más itinerante que los vistos anteriormente, que «arrastra» a observadores y participantes activos o que van a su encuentro, siempre cambiante, pues en cada sitio barrial la coreografía no será la misma, aunque la programación consecutiva se repita cada día, como en todo auténtico ritual, así sea éste básicamente profano como es el caso.

Se inicia el baile con la marcha o entrada, a la que le sigue el jarabe inglés o tlaxcalteca, donde se verifica, según el informante, la «dominación» del huehue a la Maringuilla con el chicote, o la «dominación» de un huehue a otro. Le sigue el puente o baile de los listones, que plantea una serie de evoluciones en las que los danzantes juegan, unidos por cintas, dejando pasar por debajo a las parejas que componen la cuadrilla. Esto simbolizaría, según algunos testimonios, el movimiento de las aguas, el anuncio de la primavera, el nacimiento de la vida. Los danzantes de San Jerónimo Caleras lo relacionan con un rito de fertilidad, donde a través de la coreografía se forma una especie de «serpiente humana» que simboliza la fecundación.

La estrella es una de las danzas más complicadas, pues los ejecutantes logran formar esta figura con el tejido de los listones con cascabeles amarrados a la cintura de los danzantes y no todos los barrios lo tienen en su repertorio. La garrocha consiste en un tejido de cintas alrededor de ese elemento central, danza que se puede encontrar en muchos otros sitios donde se celebra la llegada de la primavera. Otra danza que no todas las cuadrillas incluyen, aunque es una de las más antiguas, es la de la muñeca que tiene tres evoluciones principales: primero, los danzantes se toman de la mano y forman un círculo, bailando hacia la derecha y después hacia la izquierda, mientras la Maringuillla, situada al centro, tiene en sus brazos a una muñeca envuelta en cobijas y baila con un huehue. En un segundo tiempo del círculo salen otros cuatro huehues y toman una capa, formando una especie de sostén, donde la pareja anterior mantiene a la muñeca protegiéndola de un diablo que se pondrá a bailar debajo de la 
capa, tratando de alcanzarla, pero no lo logra. Para finalizar, el diablo se retira frustrado por su fracaso y la Maringuilla levanta en alto a la muñeca en señal de triunfo. La Danza de la muñeca, como hemos dicho, es la presencia divina en el carnaval, y es bastante solemne su desarrollo, pues apenas se mueven los danzantes. Lo más destacado es la canción -originariamente en náhuatl- que consiste en alabanzas de la anunciación, nacimiento, vida, pasión, muerte y resurrección de Cristo.

También bailan la «jota aragonesa» que representa el juego amoroso entre la Malinche (o Maringuilla) y Hernán Cortés, y por eso sólo interviene una pareja; y el «vals inglés» que simboliza la guerra entre ingleses y españoles, bailado esta vez por cuatro danzantes unidos por pares, uno frente al otro en el que se teatraliza una pelea.

Otra variante de los carnavales urbanos de Puebla se produce en San Baltazar Campeche y especialmente en una de sus unidades habitacionales -Granjas de San Isidro-, barrio que tiene una dimensión bastante grande al incluir 21 localidades y 27 colonias. Más que un repertorio de coreografías fijas o desplazamientos establecidos, se trata de bailar y disparar desde la mañana a la noche, haciendo gala de un vestuario peculiar y distinto cada año, para hacer quedar bien a su sección barrial.

Si observamos mediante un recorrido global estos carnavales, podemos percibir en primer lugar que algo que los une es una celebración en fechas establecidas por el calendario previo a la Semana Santa, donde lo importante es el cambio de identidad de los danzantes y su relación con el barrio. Lejos de producirse en torno a líneas «argumentales» específicas, lo más importante residirá, en la mayoría de ellas, en el desfile mismo y el conocimiento de las coreografías fijas que no deben ser transformadas o adulteradas, constituyendo una pauta, repetida con maestría a lo largo de los días y núcleo del orgullo de muchas de las comunidades involucradas.

Una vez más se pone de manifiesto la creación de un espacio imaginario, donde el proceso de transformación ha sido la base para construir un lapso de libertad, juego, comunicación y disfrute, compartiendo nuevas identidades en espacios expansivos de ficción.

\section{¿EXISTE UNA PROPUESTA METODO- LÓGICA?}

Es difícil definir cómo construir un método cuando las características de estas festivi- dades es precisamente la de ser muy diversas. Nos planteamos un prisma cruzado por varias disciplinas. Al analizar estos carnavales partimos del modelo etnoescenológico propuesto por Patrice Pavis ${ }^{28}$, donde se plantea una perspectiva que va a buscar en estas prácticas una serie de reequilibrios: Series paralelas en lugar de unidades minimas. Energía más que significación. Concreto más que abstracto. Autonomía más que jerarquía de los elementos. Perspectivas parciales más que centralización. Densidad diferencial más que homogeneidad. Sincretismo más que pureza.

Al mismo tiempo, verificamos si se cumplía una estructuración por etapas propuesta por Alexis Juárez Cao Romero ${ }^{29}$, a partir de los «rituales de paso» de Van Gennep.

Aplicar entonces los parámetros metodológicos que se propusieron requirió de una dosis de flexibilidad, en dependencia del material analizado. Pudimos comprobar cómo «los ritos de paso» casi se cumplieron en cada uno de los carnavales, pero en muchos casos estos se vieron fundidos en uno o dos momentos y en otros, por ejemplo, no era posible a veces distinguir cuándo terminaba la «despedida» y comenzaba la «clausura» sobre todo en aquellos como los de los barrios antiguos de Puebla, donde la etapa final de la fiesta se extiende casi por veinticuatro horas, alcanzando hasta la madrugada del lunes posterior a la octava. En aquellos donde el ritual se ajusta más a observaciones de tipo calendárico agrario es posible distinguir el paralelismo entre aquellos y sus distintas fases.

Las propuestas etnoescenológicas, relacionadas con las prácticas espectaculares, se aplicaron con total libertad, ya que su punto de gestación se relaciona, en su diseño original, sobre todo con expresiones sincréticas y ritualizadas, pero con vocación deliberadamente escénica, mientras nuestro objeto de estudio se produce a partir de otros parámetros conceptuales y vivenciales, gestados en comunidades de una gran tradición mestiza «espectacular», donde la construcción de una teatralidad deliberadamente desjerarquizada, paralela, fuertemente energetizada, parcial, concreta, sincrética y densamente heterogénea está dada en las bases de su origen mismo. Es un hallazgo, pues, haberlas relacionado con una metodología que se plantea ya perspectivas tan amplias y que sin forzarla pudiera dialogar con los carnavales estudiados.

La categoría que con mayor sistematicidad se pudo apreciar fue la de teatralidad, que definitivamente acompaña a cada una de
Patrice Pavis, Teatro contemporáneo: imágenes y voces, Santiago de Chile, LOM Ediciones/Universidad ARCIS, 1998, págs. 208-218.

29

Alexis Juárez Cao Romero, Carolicismo popular y fiesta. Sisrema festivo y vida religiosa de un pueblo indígena del estado de Puebla, Puebla, BUAP, 1999, págs. 56-70
Los carnavales en México. Teatralidades de la fiesta popular ILEANA AZOR 
estas celebraciones año con año. Elaborada en forma diferente en las distintas localidades analizadas, en los espacios rurales de por sí diseñados con una proyección central, la teatralidad se produce a partir de concentrar y condensar la ejecución (tanto temporal como espacial) y la mirada que descubren en la alteridad ficcional una liberación de fuentes para retroalimentar el curso de la vida misma, aunque cuando estas fiestas (en Xalitzintla y San Nicolás) se hacen cada vez más alejadas -en tiempo, por su desfase con respecto a los demás carnavales, y en distancia de los centros de poblaciones más concurridas-, estas festividades podríamos pensar se resistirían un tanto a su posible aplicación. Si embargo, no es así, pues nunca se produce la ausencia de «público» que viene en viaje de estudio, para «echar porra» a algún amigo o como visitante de comunidades cercanas.

En las zonas urbanas se construye, en cambio, una teatralidad itinerante y expansiva que se comparte entre los desplazamientos virtuosos y la construcción de una nueva identidad que se disfruta y exhibe. El ánimo de fraternidad y lazo comunal se alterna con la competencia de la premiación por el mejor vestuario y el orgullo de dejar la mejor impresión de su barrio, dentro y fuera de él. Más que la inversión del mundo -aunque ése es el concepto que se ha designado por la gran mayoría de los investigadores para acentuar el disloque o alejamiento de la cotidianidad-, es la vida la que tiene lugar ante nosotros, pero desarrollada con otra mirada y transformada por eventos que nos recuerdan la fusión de contrarios, la conversión de un espacio y un tiempo rutinario en un hecho excepcional, que se repite por voluntad de los participantes y de los observadores, en una práctica espectacular que se perpetúa y nos sirve de reflexión mimética vital.

\section{BIBLIOGRAFÍA}

Alfaro, Alfonso, Moros y cristianos. Una batalla cósmica, México, Artes de México, 2001.

Azor, Ileana, Teatralidades y carnaval. Danzantes y color en Puebla de los Ángeles, California, Gestos, 2004.

- , «ntrevista a Elvia Morales», UDLA-P, 10 de marzo 2002.

- , «Entrevista a Filemón Casas y Liboria Solano", Los Capotes, San Nicolás de los Ranchos, 16 de marzo 2003.

Los carnavales en México. Teatralidades de la fiesta popular ILEANA AZOR
- , «Entrevista a Rodolfo Guzmán.», San Pedro Cholula, 9 de marzo 2003.

— , «Entrevista a Tim Knab», UDLA-P, 28 de septiembre 2001.

Bajtin, Mijail, La cultura popular en la Edad Media y el Renacimiento, Madrid, Alianza Editorial, 2003.

Barbosa Cano, Manlio, Atlas lingüístico del Estado de Puebla. México: Instituto $\mathrm{Na}-$ cional de Antropología e Historia, 1980.

Bonfiglioli, Carlo, Fariseos y matachines en la Sierra Tarabumara: entre la Pasión de Cristo, la transgresión cómico-sexual y las danzas de Conquista, México, INI, 1995.

Cabral, Ignacio, San Miguel de Huejoitzingo, Puebla, Universidad de las Américas, Puebla, 1990.

Caro Baroja, Julio, El carnaval (Análisis bistóric cultural), Madrid, Taurus, 1965.

Castillo Rojas, Alma Yolanda y Luna Reyes, Ambrosio Javier, El carnaval en los barrios de Puebla. "El carnaval de Xonaca", Puebla, Secretaría de Cultura, 1991.

Centro Estatal de Información y Documentación de los Pueblos Indigenas del Estado de Puebla, Puebla, Kaltamatiloyan, 2000.

Dávila Gutiérrez, Joel; Serrano, Francisco; Castillo Rojas, Alma Yolanda; Guerra al pie de los volcanes. El carnaval de Huejotzingo, Puebla, BUAP, 1996.

Díaz Cruz, Rodrigo, Archipiélago de rituales. Teorias antropológicas del ritual, Barcelona, Anthropos, 1998.

Féral, Jossette, Acerca de la teatralidad, Buenos Aires, Editorial Nueva Generación/Facultad de Filosofía y Letras (UBA), 2003.

Fernández Ledesma, Gabriel, Carnaval en Huejotzingo, México, Eosa, 1986.

Florescano, Enrique, Memoria indígena, México, Aguilar, Altea, Taurus, Alfaguara, S.A. de C.V, 1999.

Gaignebet, Claude y Florentin, Marie-Claude, El Carnaval. Ensayos de mitología popular, Barcelona, Editorial Alta Fulla, 1984.

García Palacios, Emma, Los barrios antiguos de Puebla, México, Centro de Estudios Históricos de Puebla, 1973.

Giménez, Gilberto, Cultura popular y religión en el Anáhuac, México, Centro de Estudios Ecumémicos, 1979.

Gobierno del Estado de Puebla. Secretaría De Turismo, Catálogo de Ferias y Fiestas, Puebla, SECTUREP, 1998.

Juárez Cao Romero, Alexis, Catolicismo popular y fiesta. Sistema festivo y vida religiosa de un pueblo indigena del estado de Puebla, Puebla, BUAP, 1999. 
Los Municipios de Puebla. Secretaría de Gobernación, México, 1988.

Luna Reyes, Ambrosio Javier, Juego y presencia. Un modelo de análisis e interpretación de una manifestación de cultura popular: el carnaval de los barrios de Puebla, Tesis, 1996.

Marín Tamayo, Fausto, Puebla de los Ángeles; orígenes, gobierno y división social, México, UAP, 1989.

Nolasco Armas, Margarita, Cuatro ciudades. El proceso de urbanización dependiente, México, INAH, Puebla, 1981.

Pavis, Patrice, Teatro contemporáneo: imágenes $y$ voces, Santiago de Chile, LOM Ediciones/Universidad ARCIS, 1998.

Pérez Quitt, Ricardo, «La raigambre de un teatro prehispánico», Tierra Adentro, 1993, núm. 67, pág. 65.

- , «Teatro prehispánico en Puebla (Cuetzalan y Atlixco)», Máscara, 1993, Año 3, núm. 13-14, pág. 126.

Quiroz Malca, Haydée, El carnaval en México abanico de culturas, México, CONACULTA, 2002.
Remedi, Gustavo, «Del carnaval como 'metáfora' al teatro del carnaval.» Latin American Theater Review, 2001, núm. 34, págs. 127-152.

Rodríguez Shadow, María y Robert D. Shadow, Los pueblos del Señor. Las fiestas $y$ peregrinaciones de Chalma, Toluca, UAEM, 2000.

Roma Riu, Josefina, Aragón y el carnaval, Zaragoza, Guara Editorial, 1980.

Substance, 2002, vol. 31, núm. 28×3.

Van Gennep, Arnold, Le folklore français, Paris, Robert Laffont, 1999.

Vázquez Santana, Higinio y Santana Garibi, Ignacio, El carnaval, México, Talleres gráficos de la Nación, 1931.

Velázquez Mejía, Arturo, La fiesta: espacio, manifestación y comunicación de cotidianeidad bistórica, Estado de México, UAEM, 1984.

Verdi Webster, Susan, «Art, Ritual, and Confraternities in Sixteenth-Century New Spain», Anales del Instituto de Investigaciones Estéticas, 1997, núm. 70, págs. 12-25. 


\begin{abstract}
Armando Partida Tayzán
Licenciado en Filología Rusa en Moscú y Doctor en Literatura Mexicana por la Universidad Nacional Autónoma de México, imparte actualmente asignaturas on $\mathrm{cl}$ Colegio de Literatura Dramática y Teatro de la UNAM en las áreas de Dramaturgia Mexicana, Latinoamericana, Rusa y Europea, Teoría Dramática y Teorías Escénicas. Entre sus trabajos de crítica e investigación teatral destacan títulos como Teatro adentro al descubierto (1997), Se buscan dramaturgos (2002) o Escena mexicana de los noventa (2003), así como su colaboración en la colección Teatro mexicano. Historia y dramaturgia (1992).
\end{abstract}

\section{LA TEATRALIDAD ACTUAL DE LA PASIÓN EN IZTAPALAPA}

ARMANDO PARTIDA TAYZÁN

\section{RESUMEN}

Desde el puesto privilegiado que la Semana Santa tiene en el imaginario nacional trataremos de hacer un recorrido descriptivo de los episodios más relevantes de la representación actual de la Pasión en Iztapalapa. La epidemia de cólera ocurrida en 1833 hizo resurgir esta escenificación que, por otra parte, tuvo inicialmente un sentido ritual, para poder estabilizar al mundo. Así se hizo necesaria la occisión ritual del propio Salvador, quien con su muerte venía a salvar a la humanidad; al igual que lo hicieran los ancestros de los moradores actuales de Iztapalapa en la ceremonia del Quinto Sol y del Fuego Nuevo.

Estamos sin duda ante una de las escenificaciones religiosas más populares y arraigadas de entre las que se llevan a cabo a lo largo del año en diversas poblaciones del país.

\section{PRESENT DAY HISTRIONICS OF THE PASSION IN IZTAPALAPA}

\section{ABSTRACT}

With the privileged position Holy Week enjoys in the national consciousness, an attempt to describe the most relevant episodes in the present representation of the Passion in Iztapalapa will be made. The cholera epidemic in 1833 inspired the reappearance of this re-enactment, whose origins lie in the ritualistic, so as to be able to stabilise the world and put a stop to the destruction caused by cholera. In this way, the ritual occision of the Saviour himself was essential, his death saving bumanity. The ancestors of Iztapalapa's present-day inhabitants did it the same way in the Fifth Sun and New Fire ceremony.

This is without doubt one of the most popular and deep-rooted religious re-enactments amongst those taking place in different locations around the country throughout the year.

La Semana Santa en México ocupa un lugar dominante en el imaginario nacional, por ser ésta una de las representaciones etnodramáticas que más encontramos en diversas regiones del país, tanto en Guerrero, como entre los coras, los yaquis y mayos, o en el centro del país, pero la más conocida es, sin duda alguna, la representación de la Pasión en Iztapalapa, que anualmente se celebra en el Distrito Federal.
No obstante haber sido prohibidas muchas de las representaciones teatrales con tema religioso, en la segunda mitad del siglo XVIII, algunas pudieron pasar la censura. Entre éstas encontramos la escenificación de la Pasión, que a lo largo del período novohispano alcanzó una gran difusión ${ }^{1}$; misma, que debido a esa prohibición poco a poco fue extinguiéndose a fines de ese siglo. La Independencia, 
paradójicamente, vino a restaurar muchas de las costumbres populares, en particular las relacionadas con las representaciones religiosas que se efectuaban en los días de los santos patronos de los pueblos indios y mestizos.

En algunos casos, como en el relacionado con el reinicio de la representación de la $\mathrm{Pa}$ sión en Iztapalapa, éste se debió a un hecho fortuito: en 1833 la cólera morbus azotó y diezmó a la población de este poblado y, en agradecimiento de que hubiese terminado, los lugareños reiniciaron la tradición de la celebración de la Semana Santa. En la actualidad, tal representación es considerada como un hecho que ha tenido lugar «en medio de un paganismo que pretendía invocar y revivir uno de los capítulos más trascendentes de la fe cristiana, pero que se estructuró en textos ajenos a los bíblicos y hasta en publicaciones profanas ${ }^{2}$, de allí que ésta se haya convertido hoy en la escenificación religiosa más popular y más grande de entre las que tienen lugar a lo largo del año en diversas regiones del país.

I. Su inicio es el Domingo de Ramos, cuando de la calle Aztecas de este antiguo poblado de Iztapalapa, sito en el sudeste de la ciudad de México, y hoy integrado al Distrito Federal, parten cientos de actores: nazarenos; penitentes; viejos, jóvenes y niños, vestidos a la usanza del redentor, y cargando una cruz, al igual que éste -para expiar alguna culpa o pagar una «manda» por un favor recibido-, y vecinos del lugar, quienes en un tiempo se dirigían a la parroquia local, donde un cura oficiaba la misa y bendecía las palmas traídas en procesión al compás del monótono ritmo del tamborín y del flautín. Palmas procedentes de los estados de Oaxaca y Puebla, y proporcionadas por los mayordomos, encargados de ello. Luego todos se dirigían al santuario de la Cuevita, donde tiene lugar la entrada triunfal de Jesús a Jerusalén.

La representación de los sucesos bíblicos del Jueves Santo se iniciaba en el Santuario de la Cuevita pues, aunque la Iglesia no participaba oficialmente en la celebración, por ser ésta organizada por los vecinos y las autoridades locales, el «señor cura» oficiaba las misas, bendecía los ramos y confesaba a los participantes, en tanto el Obispo pronunciaba la elocución por motivo de Semana Santa; es decir: dejaban hacer a los vecinos lo que por más de 153 años habían escenificando. Más recientemente, debido al carácter mundano que ha tomado la representación, además del cambio de curas que ha tenido lugar, la iglesia local efectúa dentro de su ámbito -la nave de la iglesia y el atrio-jardín bardado- su propio festejo de Semana Santa, del todo religioso-cristiano, independientemente del gran espectáculo que tiene lugar en el exterior, a su alrededor.

Dicha elocución del Jueves Santo -previa a la procesión-, en la actualidad tiene lugar en el Jardín Cuitláhuac, donde luego se representa asimismo la Última Cena, la Ceremonia del Lavato-

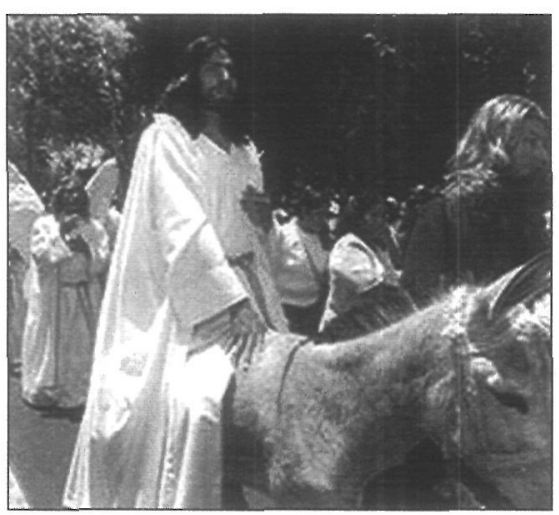

Domingo de Ramos. Iztapalapa 2006 rio, la Oración del Huerto, la Aprehensión y el Juicio de Jesús; esta última escena, seguramente es la más teatral por las vestimentas y los participantes.

La representación, inicialmente de carácter religioso, se ha tornado, con el correr de los años, en un verdadero espectáculo teatral de masas, presenciado por los creyentes locales y por cientos de miles de turistas locales, extranjeros que observan «con atención y respeto esta nueva versión del Drama del salvador; contenidos por una valla de uniformados», y que conmovidos por la condena insultan a Judas Iscariote y ríen por «la indumentaria de los centuriones, flacos como quijotes» ${ }^{3}$; perdiendo así su naturaleza inicial.

«Un cuarteto de centuriones muy sui generis, da inicio al drama, y desde lo alto del Gran Sanderín tocan la marcha dragona», en tanto que «En la explanada, unos quinientos penitentes -con túnicas moradas y un cirio en la mano-forman un cuadro para dar paso a Jesús y sus doce discípulos» ${ }^{4}$. Luego tiene lugar la escena de la Última Cena, los Doce Apóstoles ocupan sus asientos en la mesa, colocada sobre una de las plataformas, construidas ex profeso, para luego pasar al Lavatorio y después a la Oración en el Huerto de los Olivos, donde el Nazareno es aprehendido.

En la escenificación del Primer Concilio participan Caifás, Anás, Herodes y Judas, quien ofrece en venta a Jesús, escuchándose a través de los altoparlantes la tonada local del barrio, del habla de los habitantes de este poblado. Los parlamentos que intercambian los protagonistas del drama provienen de manuscritos que han pasado de mano en mano, de generación en generación, por lo que no coinciden con las escrituras sagradas, al haberse transformado -según el gusto de los participantes-, con el correr de las décadas. Por otra parte, los cambios que sufre el texto en el momento de su interpretación, ya sea por
2

Marcela Rubín, «Cinco millones costará representar la pasión en Iztapalapa», Excelsior, 26 de marzo de 1986.

3

ld.

4.

Id.
La teatralidad actual de la Pasión en Iztapalapa

ARMANDO PARTIDA TAYZÁN 


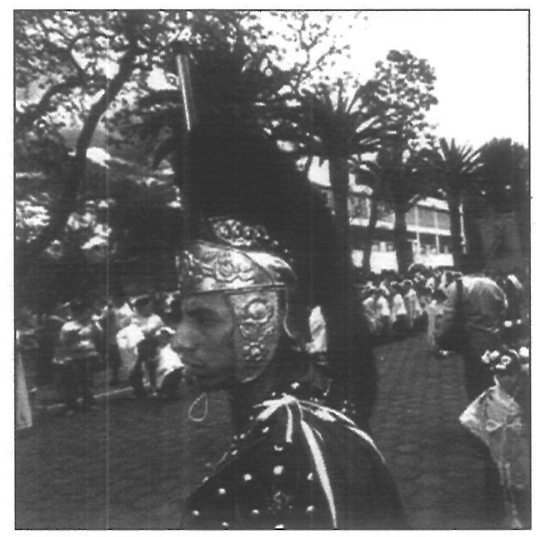

Soldado romano. Pasión de Iztapalapa 2004. habérseles olvidado, por repetirlos sin saber a ciencia cierta lo que están diciendo, o por modificarlos en el último momento, constituyen realizaciones diferentes cada vez. Lo mismo ha ocurrido con los episodios. La trama se ha visto fuertemente contaminada por elementos ajenos contemporáneos o por agregarle otras escenas, como la que va de la Loma del Cerro de la Estrella a la casa de Anás. Así, de un lado a otro, transcurre la Presentación y Juicio de Jesús, seguidos por los miles de espectadores durante todo el día y parte de la noche.

Los actores-organizadores consideran que esta representación tiene lugar en el «teatro más grande del mundo» $y$, efectivamente, así lo es: los desplazamientos de cuatro kilómetros, el paisaje urbano combinado con el natural, cada día más exiguo, junto con las enormes estructuras levantadas, constituyen un grandioso ámbito escénico, con un gran despliegue de escenografía, vestuario y utilería, además de los cientos de actores, quienes se desplazan en medio de ese paisaje urbano, que gracias a la teatralidad que está teniendo lugar y la muchedumbre que rodea al espectáculo, ha perdido tanto su temporalidad como su espacialidad originales.

El Viernes Santo es cuando tiene lugar el tercer Concilio, efectuándose un recorrido por los ocho barrios del pueblo de Iztapalapa con los tres mil actores que regularmente participan: los penitentes y los nazarenos que colman las calles. Sin duda alguna, en este día es cuando la representación llega a su máxima espectacularidad. Se inicia la procesión del Vía Crucis, que culmina en el Gólgota -el Cerro de la Estrella-, regularmente cubierto con los cientos de cruces llevadas, literalmente a cuestas, por los nazarenos participantes, y clavadas por éstos. Construidas de acuerdo a su gusto personal, y según su penitencia, cada una es de diverso tamaño y peso; además, los nazarenos van coronados con flores amarillas entrelazadas, cubriendo las espinas con las que también se castigan. Sólo la corona del Nazareno lleva al descubierto las largas espinas de cinco centímetros de largo, que hacen sangrar la frente y cabeza de éste.

Pero antes ha tenido lugar el Juicio, y a las 12:35h los clarines han anunciado que Jesús ha sido condenado y va a decidirse qué castigo darle. Mientras tanto, Herodes bebe de una copa de metal de las artesanías nacionales y muerde displicentemente un racimo de uvas artificiales, de plástico, tendido en un sofá, dispuesto en uno de los templetes. Y Pilato -llamado «presidente de la República»- desde otro observa con gravedad sentado en su trono. Jesús es de nuevo llevado de la casa de Herodes a la de Caifás. La mayoría, de los más de dos y medio millones de espectadores se agitan tratando de seguir la procesión, en tanto otros se conforman con verla al paso, a través de periscopios caseros, manufacturados con envases de cartón que antes contenían leche, jugos y otros productos.

En esta Pasión no hay resurrección. La representación concluye con la muerte de Judas, quien se cuelga de inmediato -después de la crucifixión-, a un lado del Calvario, en la cúspide del Cerro de la Estrella. El actor que interpreta este rol, que ya lo ha representado varias veces, como los otros participantes los demás papeles, ya está inquieto por mostrarnos su arte, perfeccionado a lo largo de años para recrear este personaje, para poder exhibir la larga lengua morada de cerdo que le saldrá de la boca por entre los dientes, cuando finalmente penda de la soga.

Todos los actores han sido rigurosamente seleccionados, pues deben dar el «tipo». De apóstol: jóvenes de aspecto agradable. De Judas: ¡chaparro, corpulento, y de fácil palabra y mímica! La mujer de Pilato: guapa, atractiva, un poco generosa en sus atributos físicos, para poder mostrarse pecaminosa $y$, en ese día, debe estar particularmente «bella». Barrabás: fortachón, grande, tosco, etc. Al mismo tiempo, todos deben contar con «voz clara, potente y sonora, además de capacidad histriónica», no obstante la utilización de la electrónica, pues sus parlamentos son emitidos por medio del micrófono.

La elección anual de quien representará a Jesús es la parte más importante de la preparación previa de la organización de la representación. Este debe contar con atributos físicos para poder resistir los kilómetros de recorrido cargando una cruz de 80 kilos, más las caídas, ya que no son actuadas, al igual que los golpes de los soldados «romanos». Sin embargo, los requisitos más importantes son los de haber nacido en el lugar y ser hijo de padres también oriundos del barrio. Por otra parte, debe probar su calidad moral, no tener ningún vicio, pero sí reputación intachable, ser puro y nunca haber tenido novia, para poder representar dignamente al Salvador.

Éste es elegido con seis meses de anticipación, mismo tiempo que toma su entrena- 
miento físico con largas caminatas. Desde el mes de enero se inicia su «retiro espiritual»y comienza a dejarse crecer la melena, que muchas veces es teñida -esa semana- de castaño claro (o rubio), para tener un parecido externo al Jesús de las estampas religiosas.

Un lugar muy especial ocupa la confección - la renovación del vestuario de todos los participantes, con telas brillantes y de colores chillones, junto con terciopelos y galones dorados y plateados; a lo que se agregan pelucas y un grueso y burdo maquillaje, que a pleno sol se escurre de inmediato. De esta manera salen travestidos los cientos de romanos, apóstoles, judíos y samaritanos en esta gigantesca manifestación espectacular de la popular Pasión y muerte del hijo del Hombre.

De hecho nos encontramos con una representación teatral que en la actualidad ha perdido tanto su origen como su significado religioso-cristiano, pues casi ninguno de los espectadores es capaz de explicar la razón de tal acontecimiento; por ello, no es nada raro escuchar en los labios de algún joven, responder, al preguntársele sobre el motivo de la crucifixión: "Por defendernos de los judíos, según dicen en la televisión. ¿No?».

Alrededor de los escenarios se encuentran miles de puestos con toda suerte de baratijas, mercancías y fritangas. Los gritos de los anuncios, de las cumbias y «quebraditas", vomitados estruendosamente por los altoparlantes de comercios y ferias con juegos mecánicos, compiten con el recitado torpe de los diálogos de Pilato, Herodes y Jesús, también trasmitidos por potentes aparatos de sonido; sumándose a éstos los clarines de los heraldos y la música de viento de la banda municipal en las pausas dramáticas.

II. La escenificación de la Pasión y la celebración de la Semana Santa tienen lugar en muchas otras partes del mundo católico, e incluso algunas tienen una tradición de siglos, por lo que se han convertido, además de ser una manifestación de dolor y expiación para los creyentes, en una atracción turística por sus valores estéticos y escénicos. ¿Pero qué es lo que atrae y tiene de particular la Pasión en Iztapalapa?

Mecánicamente se la ha explicado como una celebración religiosa de carácter sincrético: cristiano-pagano, en la que han sido substituidas las deidades del Panteón Azteca por las figuras de las Santas Escrituras; a partir de lo que se ha dicho del teatro evangelizador del siglo XVI, surgido en la Nueva Es- paña, una vez concluida la Conquista armada. El caso es que esta escenificación se reinició después de la Independencia, al término del primer tercio del siglo XIX. Es por ello que dicha teoría del sincretismo no podemos aceptarla del todo.

¿Qué es lo que en el fondo podemos encontrar en relación a esto? Para podernos explicar el

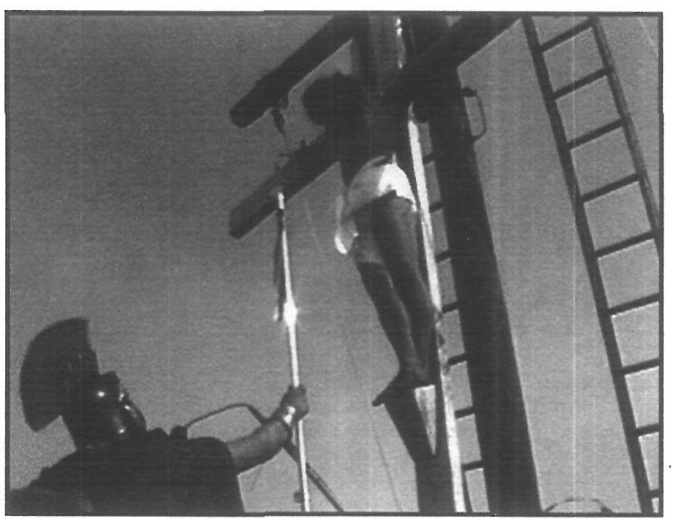

Crucifixión. Pasión de Iztapalapa 2004. contenido y la razón de ser de esta representación teatral, para poder determinar su esencia, frente a las otras celebraciones del mundo católico, tenemos que recurrir a algunas de las descripciones de los rituales prehispánicos.

Fray Bartolomé de las Casas nos dice, en su Apologética Historia Sumaria, que

Cuando los españoles entraron en la Nueva España, que fue año de 1518, por hebreo, comenzaron el año las gentes dela en primero de marzo, porque por no alcanzar bisiesto no podía comenzar de allí a otro año, y así había de ir cada año variando. Acabados los diez y ocho meses, los dichos cinco días irregulares eran muy gran solemnidad cada uno dellos, donde se celebraban muy regocijadas fiestas con grandes sacrificios y ceremonias hasta que entraba el año siguiente. El postrero día de cada mes era fiesta general en toda la tierra, y de gran solemnidad en cierto día que era postrero de cierta hebdómada de años que tenían, y este día era el postrero día de cincuenta y dos años, que era la hebdómadas.

Como podemos percatarnos, el fin del siglo mexica coincidía con la celebración de la Pascua, época en la que se efectuaban ceremonias de carácter propiciatorio y ritual:

En la ciudad de México y en todas sus provincias hacían esta ceremonia, conviene a saber, que por mandamientos de los pontífices y sacerdotes mataban todos los fuegos de los templos y de todas las casas, para esto salían ciertos ministros del gran templo de México e iban dos leguas de allí por la calzada, a una villa o ciudad llamada Iztapalápan, y subíanse en un collado y mogotes o serrejón que llamaban vixachtla, donde había un templo con quien tenía el gran rey Moctezuma muy arraigada devoción' 6 .

La referencia a que hace de las Casas es sobre la ceremonia del Fuego Nuevo, en la que el pueblo de Iztapalapa y el Cerro de la Estrella jugaban un papel muy importante.
5

Fray Bartolomé de las Casas, Apologética Historia Sumaria, edición de Edmundo O'Gorman, México UNAM, 1976, vol. 2.

6

Ibid.
La teatralidad actual de la Pasión en Iztapalapa

$\overline{\text { ARMANDO PAR'TIDA TAYZÁN }}$ 


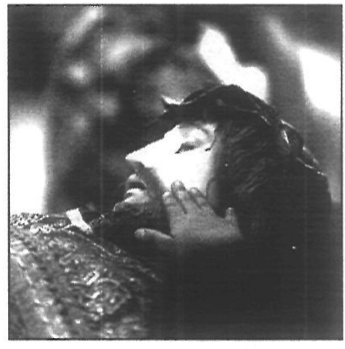

Cristo yacente. Pasión de Iztapalapa 2004.

7

Joseph de Acosta, Historia natural y moral de las Indias, edición de Edmundo O'Gorman. México, FCE, 1962.

\section{8}

Fray Diego Durán, Historia de las Indias de Nueva España, apud. Miguel León Portilla, Antología de Teotihuacan a los aztecas, fuentes e interpretaciones históricas, México, UNAM 1983.

9

Acosta, op. cit., págs. 271-275

La teatralidad actual de la Pasión en Iztapalapa

ARMANDO PARTIDA TAYZÁN
A su vez, Joseph de Acosta, al describir las celebraciones a Tezcatlipoca, nos proporciona información sobre la ritualidad mexica, también estrechamente relacionada con la escenificación de la Pasión en Iztapalapa:

...comenzaban su celebración a nueve de mayo, y acabábase a diez y nueve. En la mañana del último día, sacaban sus sacerdotes unas andas aderezadas, con cortinas y cendales, de diversas maneras. Tenían estas andas tantos asideros cuantos eran los ministros que las habían de llevar, todos los cuales salían embijados de negro con unas cabelleras largas trenzadas por mitad de ellas con unas cintas blancas, y con unas vestimentas de librea del ídolo. Encima de aquellas andas ponían el personaje del ídolo señalado para este oficio, que ellos llamaban semejanza del dios Tezcatlipoca, y tomándolo en los hombros lo sacaban en público, al pie de las gradas?

Por otra parte, en la festividad consagrada a Quetzalcóalt, celebrada en una fecha anterior, encontramos una descripción más detallada del mismo tipo de rito propiciatorio:

La fiesta de este ídolo celebraban los naturales a tres de febrero, un día después de nuestra Señora de la Purificación, según nuestro ordinario. La cual solemnidad se solemnizaba de esta manera: cuarenta días antes de este día los mercaderes compraban un indio, sano de pies y manos, sin mácula ni señal alguna, que ni fuera tuerto, ni con nube en los ojos; ni cojo, ni manco, ni contrahecho; no lagañoso, ni baboso, ni desdentado; no había de tener señal ninguna de que hubiese sido descalabrado, ni señal de divieso, ni de bubas, ni de lamparones. En fin, que fuese limpio de toda mácula.

A este esclavo compraban para que vestido como el ídolo, le representase aquellos cuarenta días. Y antes que le vistiesen, le purificaban, lavándolo dos veces en el agua de los dioses. Después de lavado y purificado, le vestían a la mesma manera que el ídolo estaba vestido, según y como queda referido de él, poniéndole la corona, el pico de pájaro, la manta, el joyel, las calcetas y zarcillos de oro, el braguero, la rodela, la hoz. Este hombre representaba vivo a este ídolo aquellos cuarenta días. El cual era servido y reverenciado como a tal; traía su guardia y otra mucha gente que le acompañaba todos los días

Como podemos darnos cuenta, para tal efecto se compraba un esclavo en el mercado, que debería estar limpio de cualquier irregularidad en la piel, para luego ser purificado y vestido con la indumentaria del dios. Mediante la propiciación y el travestismo, el hombre se transformaba en el dios en cues- tión, ocupando su lugar y las vestimentas que los simbolizaban. Lo mismo ocurría en la celebración consagrada al dios Tezcatlipoca, como explicaba fray Diego de Durán.

Si por una parte nos encontramos con un proceso de selección de quien representará a Jesús, con un período preparatorio con la misma duración de cuarenta días, por otra, el proceso de travestismo, de apropiación de la persona del dios, resulta muy semejante, además de que en principio se persigue el mismo objetivo.

Otras coincidencias muy cercanas, advertidas ya por el padre Acosta, guardan estrecha relación con algunos de los momentos de la escenificación de Iztapalapa, ya descritos anteriormente:

Después de puesto el ídolo en sus andas, tenían por todo aquel lugar gran cantidad de pencas de maguey, cuyas hojas son anchas y espinosas. Puestas las andas por dentro del circuito del patio, llevándose adelante de sí dos sacerdotes con dos braceros o incenciarios, inciensando muy a menudo el ídolo (...) Toda la demás gente que estaba en el patio, volviéndose en rueda hacia la parte donde iba el ídolo, llevaban todos en las manos unas sogas de hilo de maguey, nuevas, de una braza con un ñudo al cabo, y con aquellas se disciplinaban dándose grandes golpes en las espaldas de la manera que acá se disciplinan el Jueves Santo. Toda la cerca del patio y las almenas estaban llenas de ramos y flores, también adornadas y con tanta frescura, que causaban gran contento ${ }^{9}$.

De las descripciones anteriores, efectivamente se desprende que en las celebraciones a Quetzalcóatl, pero en particular del Fuego Nuevo y del Quinto Sol pueden encontrarse elementos escénico-rituales muy cercanos a los de la escenificación teatral de la Semana Santa en Iztapalapa:

El Año Nuevo, celebrado en marzo con sacrificios y ceremonias propiciatorias. El recorrido de dos leguas, del templo Mayor al pueblo de Iztapalapa, hasta el Cerro de la Estrella. La inclusión de la topografía. La selección de un joven que representará al dios Tezcatlipoca, al cual debería asemejársele mediante el uso de su indumentaria ritual, que contenía los diversos símbolos distintivos. Como explicaba Acosta,

...la fiesta del ídolo Tezcatlipuca era muy solemnizada. Venía esta fiesta por mayo, y en su calendario tenía nombre toxcatl. Pero la misma cada cuatro años concurría con la fiesta de la penitencia, en que había 
indulgencia plenaria y perdón de pecados. Sacrificaban este día un cautivo, que tenía la semejanza del ídolo Tezcatlipuca ${ }^{10}$;

mismo que además debía ser puro, seleccionándose entre muchos otros candidatos, para luego ser recluido en penitencia y así poder ser digno de representar al dios.

Luego venía la procesión y la participación de quienes a su vez realizaban sacrificios con las espinas de maguey; como forma ritual propiciatoria, practicada para sangrarse con esas espinas; rito, que por otra parte, se practicaba cotidianamente, a diversas horas del día o de la noche. Actos propiciatorios muy cercanos a los que tienen lugar en la Pasión en Iztapalapa: la presencia de los penitentes en la celebración del Domingo de Ramos; además del ofrecimiento de las palmas, que luego son consagradas durante la misa, y que vienen a ocupar el lugar de las ofrendas florales, tan generalizadas para agradar a los dioses; además de las penitencias de los nazarenos el Viernes Santo.

Por todo lo anteriormente expuesto, no es raro el que, cuando los cronistas actuales se refieran a esta escenificación, efectúen una transposición mecánica entre los ritos cristianos y los indígenas. Esto no tiene nada de raro, pues los propios cronistas misioneros del XVI al hacer el relato, al interpretar los ritos de los mexicas, tomaron como modelo su propio imaginario cultural y religioso (como podemos percatarnos en las extensas citas aquí incluidas), ya que, si efectuamos un análisis somero de su imaginario, a partir de su visión del mundo y su ideología, nos encontraremos que los frailes, al igual que los demás cronistas, repitieron su propio modelo ideológico al interpretar al mundo prehispánico. De allí que surja la pregunta, cuando se habla del sincretismo pagano-cristiano: ¿a qué dios o dioses se están substituyendo a través del personaje de Jesús? Partiendo de esa explicación mecanicista es difícil encontrar respuesta.

Como podemos ver, nos encontramos ante el hecho de que, durante la evangelización de los indios de la Nueva España, en el siglo XVI, no podemos hablar sólo de que haya tenido lugar un proceso de sincretismo cristianopagano, sino también de la identificación de una mística religiosa propia del poblador del altiplano mexicano. De manera que los indios pudieron fácilmente manifestarse a través de las escenificaciones cristianas, sin que tuviera lugar una substitución de sus rituales, habiendo encontrado en las manifestaciones teatrales de los misioneros los mismos componentes externos y los mecanismos internos de su propio drama, que igualmente tenían «un sentido y un fin en sí mismo»; como en este caso concreto de la Pasión, donde el Salvador moría sacrificado como uno más de sus dioses; desde su perspectiva religiosa-cultural, por haber llegado a término su ciclo, por lo cual se hacía necesaria su muerte, es decir: su sacrificio; al igual que en esta escenificación popular.

En la representación actual de la Pasión en Iztapalapa, nos encontramos conque la epidemia de cólera, que ocurriera en 1833, hizo resurgir esta escenificación que, por otra parte, tuviera inicialmente un sentido ritual, para poder estabilizar al mundo y no siguiera destruyéndose por la cólera. Así se hizo necesaria la occisión ritual del propio Salvador, quien con su muerte venía a salvar a la humanidad; al igual que lo hicieran los ancestros de los moradores actuales de Iztapalapa en la ceremonia del Quinto Sol y del Fuego Nuevo. Por otra parte, no hay que olvidar, que con estas ceremonias llegaba a término el ciclo vital de los dioses, por lo que había que sacrificarlos, travestidos en los cautivos seleccionados para ello, para así dar comienzo a un nuevo ciclo y no a una resurrección, como en el caso original de la Pasión bíblica, que no tiene lugar en la teatralización de Iztapalapa.

Es evidente que con el correr de los siglos se perdió el significado ritual original prehispánico al imponerse la ideología cristiana; sin embargo, su imaginario resurgió con el reinicio de la escenificación de la Pasión en este poblado. Con el dominio del catolicismo, la memoria colectiva trasladó a un segundo lugar el antecedente ritual de las ceremonias que se celebraban en ese lugar; en tanto, la anécdota y el relato de la Pasión de Jesús se arraigó aquí; resemantizando con ello el significado sagrado del lugar de la representación.

Lo paradójico de todo esto es que, en la época actual, ambos contenidos: pagano-religiosos, se han ido borrando, al predominar el espectáculo teatral, por la monumentabilidad que ha ido tomando la escenificación del pasaje bíblico. Aunque siguen prevaleciendo en esencia los mismos motivos religiosos, durante la realización de la dramatización dominan los aspectos de la escenificación, de la teatralidad, sobre los estrictamente religiosos. De hecho aquí tenemos uno de los ejemplos más puros del «teatro tosco» de Peter Brook, mismo que seduce al «público», compuesto por los miles de espectadores que año con año son convocados por esta representación en Iztapalapa.

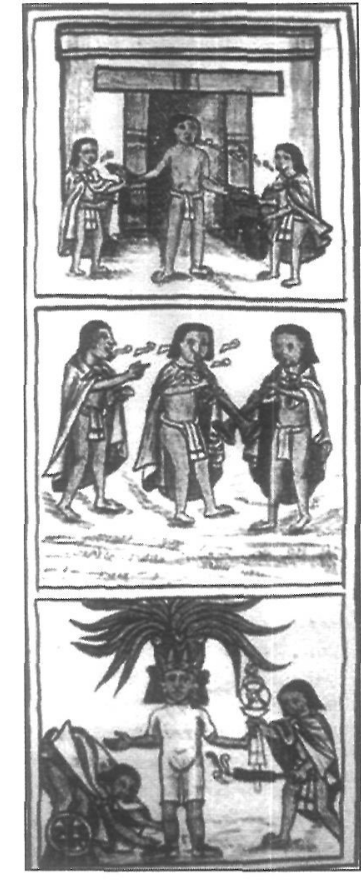

Fray Bernardino de Sahagún, pintura del Códice florentino.

10

Ibid., 275

La teatralidad actual de la Pasión en Iztapalapa

ARMANDO PARTIDA TAYZÁN 


\section{BIBLIOGRAFÍA CITADA}

Acosta, Joseph de, Historia natural y moral de las Indias, edición de Edmundo O’Gorman. México, FCE, 1962.

Casas, fray Bartolomé de las, Apologética Historia Sumaria, edición preparada por Edmundo O'Gorman. 2 vols., México UNAM, 1976.

"Con estrecheces, la Pasión en Iztapalapa», Excelsior, 28.03.1986.
León-Portilla, Miguel, Antología de Teotibuacan a los aztecas, fuentes e interpretaciones históricas, México, UNAM, 1983.

Horcasitas, Fernando, El teatro nábuatl: épocas novobispana y moderna, México, UNAM, 1974.

Rubín, Marcela, «Cinco millones costará representar la pasión en Iztapalapa», Excelsior, 26.03.1986. 


\section{NOTAS SOBRE LA FIESTA Y LA REPRESENTACIÓN TEATRAL EN LA SEMANA SANTA DE SANTA MARÍA DE TONANTZINTLA}

\author{
OCTAVIO RIVERA KRAKOWSKA
} este tema, dedicados sobre todo a las condiciones de representación en los Siglos de Oro y a figuras destacadas de este período como González de Eslava y Sor Juana Inés de la Cruz. Sus estudios se han orientado asimismo hacia teatro mexicano contemporáneo. Ha sido Presidente de la Asociación Mexicana de Investigación Teatral y ahora es editor de su revista, Investigación Teatral.

\section{RESUMEN}

Santa María Tonantzintla es una población que se localiza a cuatro kilómetros al sur de Cholula y a doce kilómetros al oeste del centro de la ciudad de Puebla. Tonantzintla debe su fama a su templo principal dedicado a la Purísima Concepción de Maria, «Santa Maria Tonantzintla», cuyo interior, de pequeñas dimensiones, es dueño de una de las muestras barrocas mas exquisitas y extraordinarias en México de lo que se puede denominar, según algunos especialistas, arte mestizo.

En Tonantzintla, como en muchas otras poblaciones en el país, la celebración de la Semana Santa es una de las mas importantes del calendario festivo. Parte fundamental de la fiesta religiosa-popular es la representación de la «Judea» que se lleva a cabo desde el Jueves Santo y hasta el Sábado de Gloria. Durante estos tres días, las distintas secciones en que esta dividida la representación teatral, y que van desde la Oración del Huerto hasta la Crucifixión, se intercalan con los actos litúrgicos, los oficios, las devociones y las procesiones, actividades, todas ellas, no exentas de teatralidad, y cuyo desarrollo busca integrar a toda la comunidad en las distintas tareas de la organización, la distribución espacial -y los actos que en ellas se realizan-, su empleo, $y$, por supuesto, la actitud espiritual.

El propósito de mi trabajo será el de revisar algunas de las características de la fiesta y representaciones teatrales de Semana Santa en Tonantzintla, así como atender a sus relaciones con otras celebraciones de este tipo en México.

\section{FEASTS AND DRAMATIC REPRESENTATION IN HOLY WEEK IN SANTA MARIA TONANTZINTLA}

\section{ABSTRACT}

Santa Maria Tonantzintla is a village located four kilometres south of Cholula and twelve to the west of Puebla city centre. Tonantzintla owes its renown to the main church dedicated to the Most Holy Conception of Mary, 'Santa Maria Tonantzintla'. The church's small interior houses one of the most exquisite and extraordinary baroque examples in Mexico of what could be called, according to come experts, Mestizo art.

As in many other villages around the country, in Tonantzintla the celebration of Holy Week is one of the most important in the festive calendar. A fundamental element of the popular religious festival is the representation of Judea that takes place from Maundy Thursday to Easter

\footnotetext{
Notas sobre la fiesta y la representación teatrai en Ja Semana Santa de Santa María de Tonantzintla 


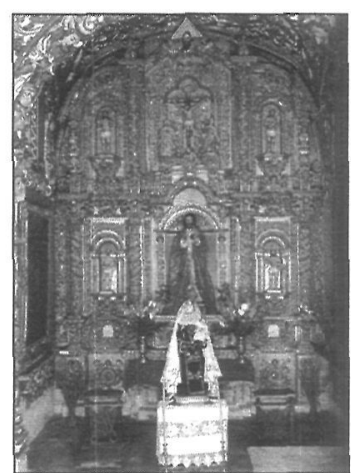

Retablo de la Pasión de Cristo. Santa María Tonantzintla.

Santa María Tonantzintla es una junta auxiliar del municipio de San Andrés Cholula, que es la cabecera municipal. El municipio está ubicado en la región centro-oeste del Estado de Puebla. Tonantzintla cuenta actualmente con una población de entre 3500 y 4000 habitantes. Según Rubial García, la fundación de Santa María Tonantzintla se puede situar hacia 1587 (Antonio Rubial García, Santa María Tonantzintla, un pueblo, un templo, México, Universidad Iberoamericana, 1991, pág. 23) y en "el siglo XVIII [...] Tonantzintla, como todos los llamados pueblos de indios de la región, era ya un poblado mestizo totalmente penetrado por la cultura española, aunque su gente seguía hablando náhuatl y llamándose con nombres indígenas》 (Ibidem, pág. 27). Actualmente, la población, como ocurre en otras muchas comunidades de Puebla, posee apellidos de origen náhuatl. En Tonantzintla, el español es la lengua dominante, al grado que es posible decir que se ho perdido el náhuatl como lengua hablada. La calidad de "poblado mestizo» que atribuye Rubial a Tonantzintla desde el siglo $\mathrm{XVIII}$, es visible en la representación de la Judea, es decir, es una representación mestiza.

\section{2}

Ibidem, pág. 119. Además de libro de Rubial sobre Tonantzintla y su templo pueden verse, entre otros, Pedro Rojas, Tonantzintla, México, Universidad Nacional Autónoma de México, 1956; la antología de textos de Julio Glockner (comp.) Mirando el paraíso. Textos sobre Tonantzintla. Antología, Puebla, Secre-

Notas sobre la fiesta y la representación teatral en la Semana Santa de Santa María de Tonantzintla

Saturday. During these three days, the different sections dividing the theatrical representation from Christ's Prayer in the Garden to the Crucifixion merge with liturgical acts, offices, devotions and processions. All these activities include some form of histrionics and their performance seeks to involve the whole community in different organisational tasks, settings - including the acts carried out therein - work and, of course, spiritual sentiment.

The aim of this work is to look at some celebratory characteristics and theatrical representations from Holy Week in Tonantzintla and study their relation to other celebrations of this type in Mexico.

\section{UNO}

Santa María Tonantzintla es una población que se localiza a cuatro kilómetros al sur de la ciudad de San Andrés Cholula y a alrededor de diez kilómetros al oeste del centro de la ciudad de Puebla en el Estado de Puebla, México ${ }^{1}$. El pueblo de «Tonantzintla», como se le conoce comúnmente, debe su fama dentro y fuera de México, a su templo principal dedicado a la Purísima Concepción de María, «Santa María Tonantzintla», cuyo interior, de pequeñas dimensiones, es dueño de una de las muestras barrocas más exquisitas y extraordinarias en México de lo que se puede denominar, según algunos especialistas,

taría de Cultura del Gobierno del Estado de Puebla, 1995, y el de Luisa Ruiz Moreno, Santo María Tonantzintla. El relato en imagen, México, Consejo Nacional para la Cultura y las Artes, 1993.

3

El Catálogo de ferias y fiestas. Estado de Puebla en lo que corresponde al listado de festividades en San Andrés Cholula, no incluye ninguna celebración durante Semana Santa (Catálogo de ferias y fiestas. Estado de Puebla, Puebla, Secretaría de Turismo del Estado de Puebla [1998], pág. 53). En el caso de Tonantzintla sólo menciona la fiesta patronal (24 de diciembre), aunque Tonantzintla celebra también la natividad de la Virgen. Sin embargo, en la sección introductoria, "Información general», sobre las fiestas en el estado, señala: «La Semana Santa es una fecha muy importante para los fieles que la guardan con devoción. En todos los municipios hay celebraciones religiosas. Empieza el Domingo de Ramos con la bendición de las palmas (Las [sic] hojas trenzadas de diversas y originales maneras). El día más importante es el Viernes Santo cuando se reza el Viacrucis y en algunos lugares se hace la representación de la Pasión de Cristo. Aquí se ven las imágenes ricamente ataviadas, mujeres con incensarios, flores y se oyen cantos entonados por los fieles. En los pueblos indígenas muchas veces es una singular mezcla de las creencias prehispánicas y la religión carólica ya que durante la Conquista los frailes evangelizadores, permitieron que los indígenas conservaran algunos de sus ritos y hoy en día se llevan a cabo en esias fechas ceremonias que datan de la época prehispánica y que no tienen relación con la Semana Santa» (Ibidem, pág. 4). El documento indica que esta información se recoge de "Calendario de Fiestas Populares. SEP. 1988» (Ibidem, pág. 5). El libro La Semana Santa en México. Con la muerte en la cruz incluye el cuadro «Rasgos culturales de la Semana Santa en los estados de la República Mexicana». En el caso del estado de Puebla registra las siguientes actividades: baile, juegos pirotécnicos, música,

arte mestizo. Su decoración y simbología, de acuerdo con los estudiosos, es una de las más ricas y complejas en el país y ha dado lugar a diversas interpretaciones ${ }^{2}$.

En Tonantzintla la celebración de la Semana Santa es quizá la más importante de su calendario festivo-religioso ${ }^{3}$. Esta fiesta incluso posee quizá mayor poder de convocatoria, que la fiesta patronal en honor a Santa María (24 de diciembre) y la de la Natividad de la Virgen (8 de septiembre) ${ }^{4}$. En la celebración intervienen los tres barrios en que se encuentra dividida la población: San Miguel, San Diego y San Pedro5. Parte fundamental de la fiesta religiosa es la representación de la pieza llamada Pasión y muerte del Redentor sóbre

feria, procesiones, alabanzas, alfombras de flores o serrín, bebida ceremonial, danzas de moros, tecuanes, Doce Pares de Francia, vaqueros, palo volador, santiagos, negros $y$ quetzales; $y$ en el listado de «Localidad con representaciones» aparecen: Cuapan, Ahuazote, Ahuehuetitla, Chitla de Tapia, Ortal, San Miguel Xoxtla y Xicotepec de Juárez. No hay mención, por lo tanto, ni a Santa María Tonantzintla ni, en todo caso, a San Andrés Cholula (Sonia Iglesias y Cabrera, Leticia Salazar Cárdenas y Julio César Marlínez Gómez, La Semana Santa en México. Con la muerte en la cruz, México, Consejo Nacional para la Cultura y las Artes, 2002, pág. 102).

\section{4}

De acuerdo con Rubial, un documento de 1790 señala «[...] que los 144 tributarios que poseía Tonantzintla colaboraban en la celebración de casi todas las fiestas dedicadas a la virgen María. Aunque la advocación del patronazgo de la iglesia era la Inmaculada Concepción, esta festividad no tenía una relevancia especial, pues se le celebraba con el mismo boato que a la Asunción de María, a Nuestra Señora de la Candelaria, a Nuestra Señora de la Encarnación, a Nuestra Señora de los Dolores y a las vírgenes de los Remedios y de Guadalupe. Al parecer todas estas fiestas marianas tenían la misma importancia [...]», y añade que a fines del siglo XVIII, «[...] después de doscientos años de vida, Tonantzintla seguía siendo un pueblo fuertemente cohesionado y profundamente unido bajo su cuerpo de república, con sus tierras comunales y alrededor de una organización religiosa centrada en el culto a la virgen María. De ella el pueblo esperaba la fertilidad de sus tierras y de sus mujeres $y$ a ella ofrendaba las primicias de sus cosechas. En su honor fue que construyeron uno de los templos más hermosos que posee nuestro país» (Rubial García, op. cit., póg. 35)

5

Cada barrio posee una capilla dedicada a su santo patrono y se edificaron posiblemente entre 1750 y 1775 (lbidem, pág. 41). 
la Pasión de Cristo a cargo de la «Corporación de la Judea». La representación se inicia el Jueves Santo y concluye el Viernes Santo. Durante estos dos días, las distintas secciones que componen la representación teatral van desde la Oración del Huerto hasta la Crucifixión, y se intercalan con los actos litúrgicos, los oficios, las devociones y las procesiones, actividades, todas ellas, no exentas de teatralidad, y cuyo desarrollo busca integrar a toda la comunidad en las distintas tareas de la organización, la distribución espacial y, por supuesto, la actitud espiritual ${ }^{6}$.

De acuerdo con la tradición popular, las fiestas probablemente se iniciaron entre 1840 y 1860 con el propósito de solicitar la ayuda divina para detener las epidemias que mermaban a la población ${ }^{7}$ y, en el periodo que corre entre 1908 y 1912, hubo un año en que se suspendieron. Los lugareños atribuyeron a este hecho una gran sequía y la pérdida de la cosecha. Desde de entonces, la fiesta se lleva a cabo año con año ${ }^{8}$.

\section{DOS}

Las fiestas de la Semana Santa en Tonantzintla están concebidas de modo que, como he dicho, participe toda la comunidad, al mismo tiempo que se tratan de ocupar todas las calles y los recintos sagrados propios de sus tres barrios. La participación de los tres barrios es de enorme importancia. El número tres es constante en muchas de las actividades que se desarrollan, así como en las formas de organización. Para estas tareas, así como la coordinación y ejecución general de las festividades de Semana Santa, se nombra anualmente, el primer día de enero, una «Directiva General» conformada por el Fiscal Mayor (Presidente), el Teniente (Secretario) y el Cera Mayordomo
(Tesorero). Cada uno de ellos debe proceder de cada uno de los barrios y estar presentes en todos los actos litúrgicos que forman el cuerpo principal de la celebración piadosa.

Esta «Directiva» acuerda comisiones con la presidencia auxiliar y los vecinos. Entre ellas, y en relación con la representación teatral, la presidencia auxiliar debe encargarse de la instalación de tres «templetes» (tarimas), una enorme lona que, a manera de techo, cubre el espacio frente a la capilla de San Pedro en donde se levantan los «templetes» para las escenas del juicio; así como de la iluminación de esta zona, ya que gran parte de la representación tiene lugar la noche del Jueves Santo. En cuanto a los vecinos, una de las comisiones más importantes es la que se compromete en la construcción y decoración del «Huerto» en donde tienen lugar los episodios teatrales de la «Oración» y el «Prendimiento».

La "Corporación de la Judea» es la responsable de la representación teatral. Realiza su tarea de manera paralela con la "Directiva», acuerdan entre sí la realización de la misma, la fecha de inicio de los ensayos, y los días y el horario en que pueden tener lugar, pero no depende de ella para la toma de decisiones en relación con los distintos aspectos de la representación. La «Corporación de la Judea» recibe de la «Directiva General» el apoyo económico para el alquiler del equipo de sonido, la alimentación de los actores durante el tiempo que dura la representación y la compra o alquiler de algunos otros implementos que puedan ser necesarios. La «Dirección» de la «Corporación» se encuentra formada por tres personas: Presidente, Secretario y Tesorero, representantes de cada uno de los barrios. Cada uno los miembros de la «Dirección» de la «Corporación» tiene un suplente, que toma su lugar en caso necesario. te estas líneas, a la difusión de la representación teatral de la Judea, al conocimiento de nuestra cultura teatral tradicional y a la de la riqueza cultural de Tonantzintla.

\section{7}

Lomeli Vanegas apunta: «Además de las fiebres que azotaron a la ciudad [de Puebla] entre 1812 y 1813, hubo severas epidemias de cólera morbo en 1833 y 1850, epidemias de sarampión y escarlatina en 1825 y de viruela en 1830. (Leonardo Lomelí Vane- gas, Breve historia de Puebla, México, El Colegio de México - Fondo de Cultura Económica, 2001, pág. 167).

8

Es posible que la suspensión en aquel año se debiera a la situación política por la que pasaba el país, y el Estado de Puebla, en aquellos momentos. A partir de 1908 se organizaron los primeros círculos políticos de la entidad producto de la apertura del presidente Díaz a este tipo de agrupaciones en vista de las futuras elec-

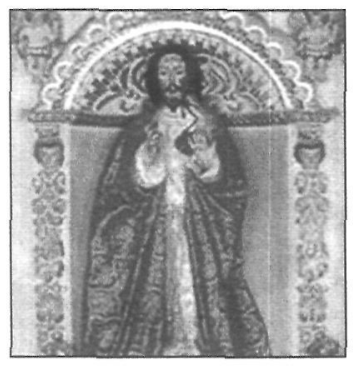

Detalle del Retablo de la Pasión de Cristo (figura empleada en la representación la Pasión y muerte del Redentor).

laron el sur del estado y establecieron un gobierno alterno al oficial. "Este gobierno zapatista adquirió tanta fuerza en la entidad que pudo mantener sitiada a la ciudad de Puebla desde marzo hasta diciembre de 1912 $y$ en algunas ocasiones estuvo a punto de tomarla. / La situación que prevaleció de hecho en todo el estado a lo largo de 1912 afectó severamente su economía. Se redujo la producción agropecuaria en virtud de que una cantidad importante de tierras se dejó de cultivar y de que varias haciendas y ranchos ganaderos fueron saqueados; disminuyó la producción indusírial, sobre todo la textil, por las condiciones irregulares que prevalecieron en el abasto de insumos y en la operación misma de las fábricas, en las que los conflictos que se iniciaron en diciembre de 1911 tuvieron importantes secuelas. El comercio quedó dislocado porque el gobierno del estado no podía garantizar la seguridad en los principales caminos. Las vías del ferrocarril y las líneas telegráficas sufrieron varios atentados y los servicios no pudieron restablecerse al instante por la situación que prevalecía. La generación de energía eléctrica disminuyó y se experimentó una fuerte escasez de mano de obra en la agricultura, la industria y las actividades extractivas. La fuga de capitales se acentuó a medida que pasaban los meses sin que el gobernador pudiera controlar la situación» (Ibidem, págs. 302-303).

siones que vivieron momentos álgidos con los asesinatos de los hermanos Serdán el mismo año. Los levantamientos populares se multiplicaron $y$, con la llegada de Madero a la presidencia de la república en 1911 , las fuerzas zapatistas, en contra de Madero, contro-
Notas sobre la fiesta y la representación teatral en la Semana Santa de Santa María de Tonantzintla

OCTAVIO RIVERA KRAKOWSKA 


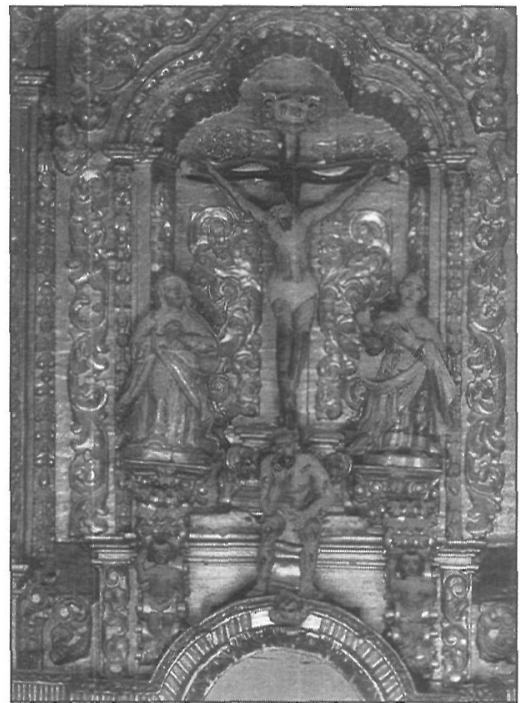

Detalle del Retablo de la Pasión de Cristo.
El Presidente ejerce su cargo durante tres años, debe formar parte de la «Corporación» y es elegido por sus miembros: los actores y el personal técnico. La responsabilidad de la «Dirección» de la «Corporación» es la de proceder a la realización de la representación y coordinar todos sus aspectos estéticos y técnicos. El «Presidente» tiene la facultad de hacer las modificaciones en la representación que considere pertinentes, particularmente las que atañen a mejoras en el espectáculo: revisión del texto que se interpreta ${ }^{9}$, cuidado del vestuario de los actores ${ }^{10}$, y de las «vistas» (los decorados de los «templetes» $)^{11}$.

De cinco años a la fecha, el Domingo de Pascua, una vez que las actividades han concluido, los miembros de la «Corporación» se reúnen y se hace un informe. En esa ocasión se abre la convocatoria para la sustitución de los actores que han cumplido con su tarea, de acuerdo con la norma, durante los tres años para los que se comprometen para representar a un personaje. En caso de que alguna persona decida suspender su participación, aun cuando no haya cumplido con el tiempo reglamentario, se ofrecen los papeles vacantes. La respuesta de la comunidad es entusiasta y, en caso necesario, se abre un periodo para la selección de los actores ${ }^{12}$.

Las tres personas que forman la «Dirección» deben estar presentes en todas las fases de la representación, al cuidado de que todo se desarrolle con normalidad dentro de lo establecido y atentos a las necesidades de los actores. Darles agua, por ejemplo, si tenemos en cuenta que hay secciones que pueden llegar a durar alrededor de tres horas y que los actores están todo el tiempo sobre el escenario. En relación con esta tarea, es normal ver a los miembros de la «Dirección», entrar, salir o dialogar en escena con los actores, durante la representación. Las "vistas» de los «templetes» deben ser retiradas por los miembros de la «Corporación» inmediatamente después de que terminan las últimas escenas que los ocupan, a lo que les sucede el desmontaje de los «templetes», tarea de la junta auxiliar del ayuntamiento. El objetivo es dejar de nuevo libre la calle en donde todo esto ha sido instalado, y seguir a la procesión que ha salido de la iglesia de San Pedro y terminará frente a la explanada de la iglesia de Santa María. En el trayecto hasta este último sitio, la procesión se detiene en dos ocasiones: una en el templo de San José y otra en el de San Diego. En cada una de ellas tienen lugar una de las «caídas»
En Santa Clara Ocoyucan se registra la representación de la Pasión de Cristo (Catálogo de ferias y fiestas..., op. cit., pág. 46). Por su forma literaria el texto, al cual sólo he tenido acceso mediante la representación, podría ser una elaboración de fines del siglo XIX o de principios del $X X$, con correcciones y adiciones resultado de sus formas de transmisión y de las adaptaciones a que ha estado sujeto a través del tiempo. El título remite al nombre de uno de los tres misterios del Rosario, los «misterios del dolor». No es claro si desde las primeras representaciones en Tonantzintla ya se decía un texto y si, en todo caso, era el mismo que se dice hoy. En la representación de la Pasión en Iztapalapa -una de las más difundidas y estudiadas en México, y que se iniciaron hacia 1833 (Adriana Luna Parra (coordinación general), Semana Santa en Iztapalapa, México, Departamento del Distrito Federal - Delegación Iztapalapa, Universidad Autónoma Metropoliłana-lztapalapa- El Juglar, 1992,

Notas sobre la fiesta y la representación teatral en la Semana Santa de Santa María de Tonantzintla

$\overline{\text { OCTAVIO RIVERA KRAKOWSKA }}$ pág. 227), fecha alrededor de la cual se supone comenzaron las fiestas de Semana Santa en Tonantzintla-, los textos provienen de adaptaciones de la novela de Enrique Pérez Escrich (1829-1897) El mártir del Gólgota y de Los cuatro concilios para la celebración de las tres caídas de Semana Santa, editado por Antonio Vanegas Arroyo, entre fines del siglo XIX y principios del XX (Iglesias y Cabrera, op. cit., págs. 187188). La representación en lztapalapa introdujo estos textos hacia fines del siglo XIX. Algo similar podría haber ocurrido en el caso de Tonantzintla. De acuerdo con los informes sobre Tonantzintla, como he dicho, las fiestas de Semana Santa se iniciaron en la primera mitad del siglo XIX, lo cual no implica que desde un principio hubiera habido representación teatral. El «Presidente» de la «Corporación» puede incluir textos, eliminarlos, reducirlos. En 2005, por ejemplo, el texto de Nicodemus, que anteriormente duraba cerca de una hora, se redujo. La longitud del texto y el momento en que se decía (en la madrugada) no retenía la atención del público quien prefería retirarse. Tecuanhuey considera que el año entrante se recortaran otros textos, pues la gente quiere ver "acción» y que cuando algo se recorta o elimina hay que incluir otras acciones y personajes que enriquezcan la obra.

\section{0}

Cada actor es dueño de su propio vestuario, el cual manda a hacer y paga. El traje se hace de acuerdo con las instrucciones que recibe de la «Corporación» y, en principio, debe corresponder al tipo de personaje, su rango social y la comunidad cultural a la que pertenece de acuerdo con la historia representada. Hay una intención de reproducción histórica del traje, aunque es posible observar la inventiva personal en la recreación de los modelos. Cada año se intenta que el personaje enriquezca su vestuario, mediante mejores telas y adornos según corresponda.
11

Las "vistas» son el único objeto que forma parte del acervo material de la «Corporación».

\section{2}

Cuando hay más de una persona que desea representar un papel se hace una selección para elegir al mejor. Para la selección, los aspirantes reciben los textos para que los memoricen y los representen en una especie de "audición". Sobre ello se hace la selección. La edad promedio de los actores en la actualidad es de entre 25 y 30 años. Antes los papeles eran representados por personas de más de 35 años. Tecuanhuey opina que la negativa de personas mayores para participar se debe a cierta «timidez». Anteriormente los papeles eran representados por la misma persona durante más de tres años. La presidencia de la "Corporación» decidió, hace aproximadamente seis años, que los actores representaran un papel por un máximo de tres años. Este cambio se implementó con la intención de atraer a más espectadores. Cuando una persona interpreta un papel por primera vez, la memorización debe empezar en octubre del año anterior. Los ensayos generales de la representación se inician el Miércoles de Ceniza de cada año. En los ensayos se cuida particularmente lo referente a «encajonar», que consiste en que cada actor sepa cuando es su turno para intervenir en la obra. Se supone que los actores deben llegar a los ensayos con su papel aprendido pues desde octubre se han comprometido para la representación. En principio, el reparto es básicamente el mismo, durante tres años, aunque por supuesto, como he dicho, puede haber cambios anuales. Los cambios de acuerdo al nuevo reglamento se hicieron también para que más miembros de la comunidad tengan la oportunidad de participar de forma activa en las representaciones; por otra parte, son ellos, quienes tienen preeminencia en la representación de los papeles. 
que señala el Vía Crucis. La última caída, la tercera, y la crucifixión se representan en la explanada frente a Santa María.

\section{TRES}

\section{Las fiestas de Semana Santa en Tonantzint-} la se inician el Domingo de Ramos y terminan en las primeras horas del Domingo de Pascua. La representación teatral tiene lugar el Jueves y el Viernes Santos ${ }^{13}$.

Jueves Santo. A las siete de la mañana se empieza a rezar el Rosario, se hacen plegarias y cantos. La imagen del Sagrado Corazón de Jesús, talla de madera colocada sobre andas, es venerada por los doce apóstoles representados por jóvenes de Tonantzintla. La expresión de la imagen es dolorosa y sus brazos están extendidos hacia el frente. Sobre ellos durante esta fase de la celebración se deposita una rosa de color rojo. La imagen viste de morado y lleva una gran capa de brocado de color hueso con dibujos abstractos en morado y oro. Para la tradición piadosa de Tonantzintla la imagen es milagrosa y forma parte del tesoro artístico de la iglesia. Durante todo el año, está colocada en el «Retablo de la Pasión». Esta imagen es extremadamente im-

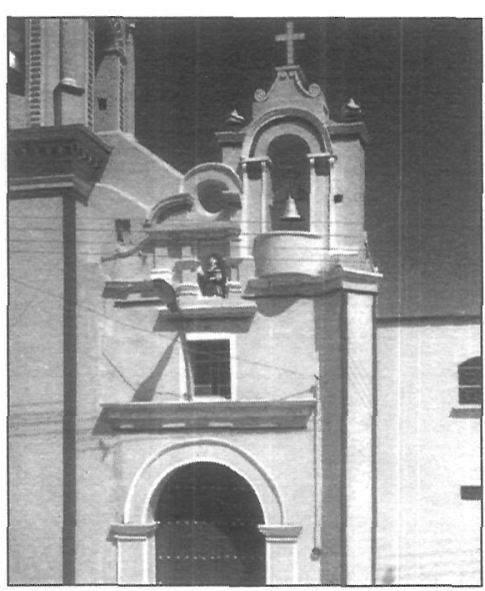

Ermita de San Diego, Tonantzintla.
13

Antes, a partir del Miércoles de Ceniza, los vecinos, frente a sus casas, suelen adornar el piso de la banqueta, todos los viernes hasta el último antes del Viernes Santo, con hileras de pequeños manojos de flores como ofrenda devota. Es común que se empleen "pensamientos», pequeñas flores del litúrgico color morado de los ornamentos de cuaresma y las celebraciones de la Semana Mayor. El Domingo de Ramos, los mayordomos de cada uno de los tres barrios salen muy temprano por la mañana hacia las tres localidades más importantes del municipio de San Nicolás de los Ranchos (a $28 \mathrm{~km}$ de la Ciudad de Puebla) que se encuentran en las faldas de los volcanes Popocatépetl e Iztaccíhuat: San Nicolás de los Ranchos, Santiago Xalitzintla y San Pedro Yancuitlalpan, en donde una buena parte de su territorio está formado por extensos bosques de pinos. Gran cantidad de ramas de una de sus variedades, conocida en México como "ocote", son las que se cortan y sirven para elaborar las "enramadas» («sombras»), techos que se colocan en el atrio de los templos en Tonantzintla entre la entrada principai de la iglesia y la puerta de acceso al atrio de modo que comunican una puerta con la otra; y para armar los "ramilletes». La visita por parte de las autoridades de Tonantzintla, y su propósito, se comunica al municipio de San Nicolás de los Ranchos desde octubre del año anterior al de la fiesta y el día de la visita se les Ilevan regalos. La visita en el Domingo de Ramos a estas comunidades termina alrededor de las cuatro de la tarde. Los troncos de "ocote», con los que se levanta la estructura que soporta las ramas frescas del mismo árbol, se tienen de tiempo atrás. Las "sombras» se componen, además, de hojas de palma. Contar con estas últimas es responsabilidad de los «Mandones» quienes las llevan a Tonantzinta desde Acatán - Atencingo, localidades al sur del estado de Puebla. Las hojas de palma, a diferencia de las ramas de "ocote", se trasladan envueltas en papel por ser más delicadas $y$, quizá, por tener una función más cercana a los actos litúrgicos. Además de ser usadas en la decoración de las "sombras», una parte de las palmas es bendecida durante la fiesta del Domingo de Ramos -día en que se hace una procesión con la imagen de San Ramitos-, y forman parte de las insignias que caracterizan a los jóvenes que representan a los doce apóstoles, quienes las usan en algunos de los actos litúrgicos, así como en parte de la represenfación. Las palmas se dejan en la iglesia después de la procesión del domingo. El Martes Santo, la hoja de la palma es tejida personalmente por su dueño. Este mismo día se adornan e instalan, junto a los muros del templo, los doce "ramilletes», fuertes y altos troncos de "ocote», en el interior de la iglesia de Santa María, entre el frente de la capilla mayor y la entrada a la iglesia. Los «ramilletes» están cubiertos de ramas de "ocote» y hojas de palma. A los que están junto a la capilla mayor se les cuelgan jaulas con palomas, cuyo canto anuncia el tiempo de la muerte de Jesús. A cada barrio le corresponde la colocación y adorno de ocho de los 24 "ramilletes»: cuatro por cada barrio dentro y fuera de la iglesia. Por tradición, los primeros cuatro «ramilletes» más cercanos a la capilla mayor del templo, dos de cada uno de los lados de la nave la de la pequeña iglesia, le corresponden al barrio de San Miguel, le siguen, los cuatro del barrio de San Diego y junto a la puerta de entrada de la iglesia se instalan los del barrio de San Pedro. La iglesia de Santa María Tonantzintla está en el barrio de San Diego, aunque por ser la iglesia mayor de la comunidad no pertenece a ningún barrio $y$, por lo tanto, todos los habitantes de la población se encargan de cuidar la iglesia y sus alrededores. La comisión encargada de levantar los "ramilletes» debe ofrecer una comida a todos quienes participan en el trabajo. Al centro de la nave de la iglesia cuelga horizontalmente el "cielo»: un enorme marco de madera adornado por una cortina elaborada con hojas de papel de china de color morado. De él, penden frutas naturales: piñas, sandias, mameyes, melones chinos, racimos de plátanos, el fruto del coco, grandes obleas de colores: violeta, amarillo, rosa, blanco, y enormes "piñas» del pino. El Miércoles Santo, en el atrio, se levantan y adornan los doce «ramilletes» que soportan la "sombra». La «sombra» se pone el Viernes de Dolores en todas las iglesias de la población a excepción de la de Santa María. Su orden es el mismo que se ha seguido dentro de la iglesia: junto a la entrada al templo están los de San Miguel, después los de San Diego y a la entrada al atrio los de San Pedro. El sitio que ocupan los cuatro "rami\|letes» de cada barrio, dentro y fuera de la iglesia, parece obedecer a viejas discordias entre los barrios en relación con las preeminencias econó- micas y sociales y su importancia en la evolución histórica de la ciudad. Por tradición, la preeminencia la tiene el barrio de San Miguel. Este orden de cercanía respecto de la capilla mayor también se sigue en el que ocupan quienes representan a los apóstoles cuando se encuentran fuera o dentro de la iglesia. De la «sombra», en el atrio, cuelgan frutas naturales: piñas, mameyes, las «piñas» del pino. De acuerdo con la tradición, las frutas deben ser naturales, aunque este año hubo algunos adornos de papel de china imitando frutas: piñas, racimos de uvas, manzanas. Los escalones de acceso al atrio, cuyo pórtico de entrada está formado por un muro con dos arcos, se cubren de pétalos de flores. Así, el aspecto plástico, odorífero (el "ocote") y sonoro (el canto de las palomas y el Viernes Santo el de un gallo), sobre todo el del interior del templo, impresiona y conmueve al visitante. El espacio recargado de la decoración vegetal cubre una parte de la riqueza decorativa de los muros del templo, de manera que parece que se ha entrado a un bosque. El Jueves Santo un lienzo enorme de color morado, el «luto», oculta a la vista la capilla mayor. Sobre los muros laterales de la nave se encuentran visibles sus cuatro retablos permanentes. Cada uno de estos altares está decorado de manera sencilla con carpetas de papel picado, rosetones de palma tejida, pequeñas macetas de latas cubiertas por papel de china de color morado con chía germinada. La capilla de crucero, a mano izquierda de la capilla mayor, tiene un retablo dedicado a la Pasión de Cristo. La figura principal es un Cristo crucificado, rodea-

do por otras cuatro pequeñas figuras de Jesús en distintos mo mentos de la Pasión. Esta capilla en Semana Santa, se adorna ricamente con un altar efímero de tres pisos dedicado a Cristo en el Huerto de los Olivos. A los lados de una reproducción litográfica de una pintura de Cristo en oración en el Huerto, que es el objeto principal de este altar, se encuentran doce candelabros de una sola y larga vela blanca que también han sido ornados con rosetones de palma tejida y pequeñas banderas de papel picado de colores oro y plata. El papel picado, tanto el que se encuentra en los altares laterales como el de las banderas, presenta imágenes del cáliz con la hostia o el rostro de Jesús. A los lados de los candelabros se encuentran enormes jarrones cuajados de azucenas. Sobre el piso hay gran cantidad de veladoras en recipientes de vidrio incoloro llenos de aceite. Estas veladoras se prenden el Jueves Santo y se refiran el Viernes Santo. Las veladoras se regresan a sus propietarios. Los miembros 


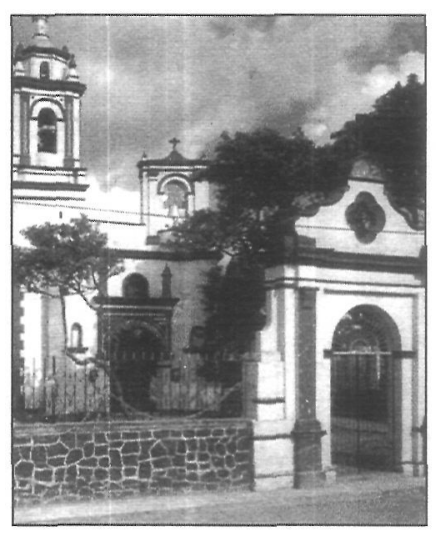

Ermita de San Miguel, Tonantzintla. portante, tanto en la liturgia de las fiestas como en la representación teatral de la cual es de hecho el «actor principal». Desde sus orígenes, la representación teatral de Tonantzintla nunca ha considerado a una persona para que represente a Jesús, aspecto común en otras representaciones de la Pasión en el país, y elemento que también distingue a la de Tonantzintla. El empleo de esta imagen de bulto, utilizada desde las primeras representaciones, desea mantener el carácter sagrado, la fe, el respeto y la solemnidad de la representación.

La imagen se encuentra escoltada, como he dicho, por doce varones -de preferencia solteros- de entre quince y veintiocho años que representan a los apóstoles. Los apóstoles van descalzos y visten alba blanca, capa de color, y una especie de «mantel» blanco doblado en forma triangular y bordado con símbolos de la eucaristía cubre sus hombros. Sobre sus cabezas llevan una corona de espinas entretejida con flores cuyos colores de preferencia podrán ser el morado y el blanco. Estos jóvenes provienen de los tres barrios de la población, cuatro por cada barrio, y su participación, en principio, está sujeta a turno según una larga lista. Los apóstoles pueden distinguirse por llevar capas de tres colores distintos, cuatro por cada color y barrio: azul, morado y rojo, por ejemplo ${ }^{14}$.

La imagen de Jesús (dentro o fuera de la iglesia $)^{15}$ recibe de frente al feligrés. Entre la imagen de Jesús y los apóstoles y la entrada al atrio hay dos columnas formadas, cada una de ellas, por seis mujeres jóvenes, que visten una blusa de color azul marino y pantalón de color hueso. Ellas son las «faroleras» quienes se encargan de llevar un farol cada una de ellas, de las oraciones y los cantos en cada una de las fases de la celebración ${ }^{16}$.

Lavatorio y Última Cena ${ }^{17}$. La misa de la «Institución de la Eucaristía» o «De Lavatorios» se inicia a las tres de la tarde. La conclusión de la misa se enlaza inmediatamente con una representación de la última cena. Para ello se coloca una mesa en donde los apóstoles ocupan sus lugares: seis de cada uno de los lados de la mesa. El sacerdote, todavía como parte del acto litúrgico, representa a Jesús. Cada apóstol recibe un plato, un pan y una copa en donde se le sirve sidra. El acto se celebra en silencio. Los apóstoles cortan una parte del pan y el resto lo comparten con los feligreses. Al terminar la misa, el sacerdote anuncia la representación de la «Corporación de la Judea». Durante la misa se han escuchado flautas y tambores cuyo sonido viene del exterior del atrio. El sacerdote se retira. Se inicia, entonces, la «Búsqueda del Redentor», se escucha la voz de Jesús, a través de un altavoz, con ello se da principio a la representación teatral. El actor que hace la voz de Jesús está oculto, de manera que nunca pueda ser visto.

En tres ocasiones, una por cada barrio, aproximadamente cincuenta jóvenes de edades de entre 10 y 20 años, aproximadamente, que representan al ejército romano, entran al atrio. La idea de las entradas es intimidar a los apóstoles y a Jesús. La llegada al atrio está precedida por tres o cuatro jóvenes a caballo. El ejército entra al atrio y forma una valla para apartar y resguardar a los fieles. La valla está formada por una categoría de soldados cuyo traje «a la romana» se distingue por sus colores blanco y negro quienes delimitan un pasillo con sus lanzas de madera. Por el centro del pasillo entra el resto del ejército haciendo sonar flautas de pico y tambores, estos soldados visten de blanco y rojo. Este enorme contingente está precedido por dos soldados de blanco y negro quienes llevan faroles y cadenas las cuales golpean contra el piso de piedra del atrio. Llegan hasta donde se encuentra la imagen de Jesús a la cual los apóstoles ocultan con las hojas de palma tejidas y adornadas con flores. Los soldados buscan a Jesús pero no lo encuentran. Al finalizar la tercera entrada, Jesús es descubierto. Acto seguido da principio la procesión hacia el «Huerto» ${ }^{18}$.
18

La procesión está encabezada por la imagen en andas de Jesús y es transportada por los doce apóstoles, tras ellos o los lados, dependiendo del ancho de las calles por donde se circula, y

Notas sobre la fiesta y la representación teatral en la Semana Santa de Santa María de Tonantzintla

OCTAVIO RIVERA KRAKOWSKA de la cantidad de gente que acompaña la procesión, marchan las faroleras. El camino de la procesión se encuentra decorado por los habitantes de las casas que dan a estas calles. El camino se adorna y señala con techos de hilos de pequeños lienzos de papel o plástico picado de colores blanco y morado. Los papeles presentan imágenes de los símbolos de la euca- ristía, imágenes de Cristo, la Virgen de los Dolores o flores. Sobre las paredes de las casas o establecimientos se cuelgan adornos también de papel, palmas, rosetones tejidos de hojas de palma. El piso del camino de la procesión está marcado por flores, pétalos de flores, hierbas aromáticas 0 aserrín pintado de distintos $\mathrm{CO}$ lores formando distintas figuras Inuevamente las propias de la eucaristía). En algunos tramos, aquellos en donde el camino es de tierra, los vecinos riegan el piso para evitar que se levante el polvo. En el camino de la procesión se visitan las tres iglesias de los tres barrios: 1. San Diego; 2. San Miguel y 3. San Pedro. Se hace una pequeña parada en cada una de ellas. Las iglesias también han sido adornadas, a la manera de la de Santa María, aunque de manera más sencilla: una enramada con hojas de pino y frutas frente a la puerta principal y el marco con frutas que pende al centro de la nave. Las iglesias son pequeñas y no incluyen los «ramilletes» que se ponen en el interior de Santa María. Durante la procesión se alternan las oraciones y cantos de las faroleras - a quienes responden quienes acom pañan la procesión-, con la 
Oración del Huerto. El «Huerto» se construye al nivel del piso y en esta ocasión tenía la forma de una «L». Se delimita con grandes macetas, muchas de ellas con pequeños cipreses, y está techado con una enramada de «ocote». La calle se cierra con este "Huerto» y con un enorme lienzo con una pintura que representa a Jesús en oración y a un ángel que arroja luz sobre él. El ángel que lo consuela, según la versión de San Lucas ${ }^{19}$. La procesión llega al sitio, entra por la parte más larga del pasillo y la imagen de Jesús es colocada como en oración frente a una capilla doméstica y está acompañada de los apóstoles y las faroleras quienes ocupan el espacio frente al lienzo. La imagen no debe darle la espalda a la capilla de San Pedro. En el sitio tienen lugar nuevamente oraciones y cantos.

Traición de Judas y Prendimiento. Cuatro de los apóstoles se separan de la imagen en andas y se sientan en el suelo en el pasillo de la entrada. Forman dos grupos que fingen dormir recargando su espalda sobre la del compañero. Al lugar llegan los soldados romanos y los pretores buscando a Jesús. La imagen en andas es removida del sitio en que estaba y se coloca en la boca del pasillo. Los soldados preguntan quién de ellos es Jesús. El actor que representa a Judas, quien acompaña a los soldados, se acerca a la imagen y la besa. Los soldados deciden acercarse a la imagen pero su paso es impedido por los apóstoles que estaban sentados sobre el piso. Hay forcejeo. Los soldados se acercan a la imagen y se interpone Pedro quien le corta la oreja a Malco. A Judas se le entregan las monedas. En 2005, en toda esta escena se usaron como música de fondo pasajes de la música de la película La pasión de Cristo (2004) dirigida por Mel Gibson. Los soldados se llevan preso a Jesús. Le sujetan en las manos largas cadenas doradas de plástico y le cubren los ojos con un lienzo fino. La procesión se inicia de nuevo y regresa a la explanada frente de la iglesia de San Pedro. El camino se acompaña de cantos, oraciones y música.

\footnotetext{
música solemne que interpreta una banda de doce integrantes compuesta por instrumentos de viento: una tuba, dos saxofones, trombones $y$ trompetas; y percusiones: dos tambores $y$ unos platillos. La última iglesia que se visita es la de San Pedro. De ahí la procesión avanza hacia el «Huerto» instalado aproximadamente a un kilómetro de la última iglesia visitada. Desde Santa María
}

Juicio en el Sanhedrín. La procesión llega al frente de San Pedro. Un gran tramo de la calle frente a la iglesia (aproximadamente $50 \mathrm{mts}$.) está cubierto por un enorme toldo a cuyos extremos se han levantado sobre el piso dos tarimas («templetes») de aproximadamente seis metros cuadrados cada una de ellas. En este momento los «templetes» representan el Sanhedrín y, el viernes por la mañana, los Pretorios. El acceso a la superficie de las tarimas se hace por el frente, por escaleras de aproximadamente seis escalones, que ocupan casi todo el ancho del escenario, pero que dejan un espacio libre de aproximadamente dos metros y medio. La cara frontal de ambos escenarios está una frente a la otra. Las tres paredes del escenario de la derecha están cubiertas por cortinas de terciopelo color vino, cuyo borde superior lleva una galera con borlas de color verde olivo. Los cortinajes recuerdan el gusto del siglo XIX. Sobre el escenario hay alrededor de doce asientos entre sillas y sillones, con el respaldo hacia las paredes. El sillón principal, el del centro, está tapizado de terciopelo rojo. A los lados del escenario, al frente y sobre el piso hay dos grandes figuras de águilas de cerámica. El segundo escenario está decorado en un estilo similar al del primero, con cortinas sillas y sillones, pero en este caso los cortinajes son de color azul claro y, en lugar de águilas, hay dos grandes cobras de cerámica.

La imagen de Jesús es transportada hasta el frente del Sanhedrín de cortinas color vino y el juicio da principio. A partir de este momento, y hasta el final de esta primera parte del juicio, que dura aproximadamente tres horas, los apóstoles sostienen en las andas la imagen de Jesús que queda junto al escenario, y a su altura, ocupando el espacio libre de escaleras de la parte frontal. El juicio, pues, se inicia en el escenario de la izquierda. Una segunda escena tiene lugar frente al escenario de la derecha, la de las declaraciones de los cinco «testigos» y termina nuevamente en el escenario de la izquierda. Durante la representación del juicio, los actores emplean micrófonos inalámbricos y las breves intervenciones orales de Jesús, aquí como en todas las escenas en que participa, como antes he dicho, las ejecuta un actor oculto a la vista del público del cual sólo se escucha su voz a través de los pletes» que se emplean en esta parte de la re-
19

La decoración del «Huerto» es tradicional aunque trata de ser enriquecida cada año. Desde hace tres años se pone el gran lienzo con la imagen de Jesús y el ángel en el huerto. La colocación de ese lienzo ha sido acordada por los presidentes de las distintas comisiones que se encargan de la fiesta. La forma del huerto en «L» la decidió la familia que aceptó la comisión de realizarlo. Esta comisión puede cambiar cada dos años. altavoces.

De acuerdo con cada uno de los «tem-

Notas sobre la fiesta y la representación teatral en la Semana Santa de Santa María de Tonantzintla de San Pedro rumbo al pueblo de Chipilo. 


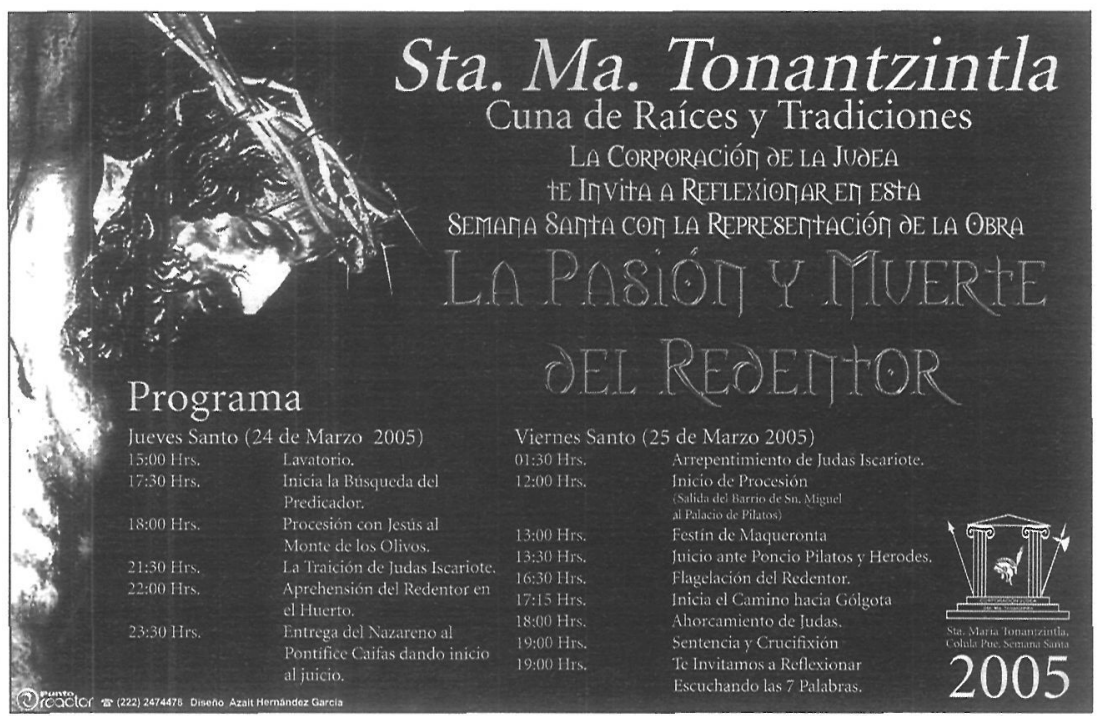

Programa de la Semana Santa de Santa María Tonantzintla 2005.

20

Mientras tanto en el interior de la iglesia de Santa María se han colocado nuevos objetos. Frente al arco de donde pende el «luto» se ha desplegado otra enorme cortina de color negro que sólo cubre la mitad de arriba a abajo del espacio abierto. Esta cortina está adornada con un enorme crucifijo que descansa sobre un cuadrado formado también con pasamanos dorados. Al entrar al templo, se puede ver, entonces, al fondo un paisaje de dos colores: el negro de la primera cortina y el morado de la segunda. Frente a esta última se ha levantado un altar con dos superficies, la de arriba de menor tamaño que la de abajo. Ambas están cubiertas de tela negra y sobre la superior, un enorme crucifijo de madera labrada sostiene la figura de un Cristo de expresión sufriente y piel oscura y manchada, el perizoma de mandil es de brocado color blanco y plata. Al lado izquierdo del crucifijo está una figura de la Virgen de los Dolores y, a la izquierda, una de San Juan Evangelista vestido de blanco con el atributo del cáliz envenenado. En los extremos de esta superficie dos pequeñas y hermosas esculturas de los ladrones, Dimas y Gestas, en sus cruces, completan el cuadro. En los extremos de la superficie inferior dos enormes candeleros sostienen largas velas negras. En la parte superior del «luto» se han puesto dos imágenes

Notas sobre la fiesta y la representación teatral en la Semana Santa de Santa Maria de Tonantzintla

OCTAVIO RIVERA KRAKOWSKA

presentación, el cuerpo de soldados romanos de blanco y negro, delimita con las lanzas un espacio rectangular frente al escenario, en cuyo interior aguardan los soldados que hacen sonar tambores y flautas cuando se desplazan de uno a otro «templete». El público ocupa de pie el espacio libre que rodea a la valla de soldados. En este espacio abarrotado de gente están quienes atienden la representación, puestos de comida, vendedores ambulantes y la gente que asiste a la especie de feria que se ha formado frente al templo. De este modo, es evidente que no hay silencio para escuchar lo que dicen los actores, quienes compiten con la algazara de feriantes y vendedores. Para la «Dirección» de la «Corporación» esta es una de las secciones más complejas. Se trata de largas escenas en donde un alto porcentaje está formado por monólogos de quienes declaran a favor o en contra de Jesús. A nivel textual,

circulares que representan a la luna, a la izquierda, de gris $y$ con los ojos mirando hacia el cielo y, a la derecha, el sol, en rojo, cuya mirada ve al frente. El dibujo de ambos rostros recuerda el del rostro central de la piedra del sol o calendario azteca. A lo largo del día y hasta el momento en que la procesión regresa al templo, un grupo de doce mujeres adolescentes, las «Magdalenas» vestidas de túnicas y capas moradas y con el cabello largo y suelto, suben, una a una, hasta el pie del crucifijo, al cual se abrazan estáticas, es, sin duda, la sección más demandante para los actores, entre otras razones, por la longitud de los textos.

Entre el inicio de la Misa de Institución de la Eucaristía y el fin de esta parte de la representación, transcurren alrededor de doce horas de actividad constante por parte de quienes participan del festejo. Una vez que termina la primera parte del juicio, la procesión camina hacia la capilla de San Miguel que funge como la cárcel de los hebreos. La procesión avanza tres pasos y regresa dos. El lento retorno busca retrasar el encarcelamiento y coincidir con el amanecer del Viernes Santo. La llegada a San Miguel ocurre alrededor de las cinco de la mañana.

Viernes Santo. Las actividades del Viernes Santo se inician alrededor de mediodía. La imagen de Jesús en andas regresa frente a los «templetes» frente a la iglesia de San Pedro, para continuar con el juicio ${ }^{20}$.

Cristo ante Pilatos. Frente a la iglesia de San Pedro el juicio continúa. Jesús, en las andas, escucha los discursos y veredicto de Pilato. En esta secuencia del juicio del Viernes Santo, además de los dos escenarios descritos anteriormente, se ha levantado otra plataforma, sin decorado, de menor tamaño. Esta superficie se encuentra a la mitad del camino entre las dos anteriores, y a un lado, de modo que no obstruya el pasillo que se forma entre los escenarios que están frente a frente. La plataforma está ocupada por los judíos Onkelos, Caifás y Anás. Los tres escenarios se emplean de modo simultáneo. El de la derecha es ocupado por Pilato y su corte. Para este día el «templete» de Pilato ha sido enmarcado con dos columnas y un tímpano simulando un palacio romano. El de la izquierda representa el palacio de Herodes. Durante el juicio se produce una aparente alteración del orden. Los ladrones que acompañaran al Cristo crucificado roban comida de uno de uno de los puestos efímeros de la pequeña feria y corren a resguardarse en una casa. Los ladrones apenas visten un burdo calzón hecho por un largo lienzo de algodón, su cabello está revuelto y sobre la cara y el cuerpo les han maquillado suciedad y heridas.

El vestuario de los jueces romanos y judíos parece inspirado por los trajes de las imágenes en los templos. Terciopelos, telas de reflejos de oro y plata, capas, cordones con borlas doradas, mantos, túnicas. En esta secuencia del juicio intervienen mujeres, aunque no hablan. Sus trajes son más simples, de colores pálidos, con velos o piezas de tela colgando 
de los hombros que den la impresión de trajes romanos femeninos. Casi todas llevan tiaras de pedrería de las que se usan, en México, para coronar a las reinas de las festividades populares o a las quinceañeras.

Ecce Homo. Al terminar el juicio, a la figura de Jesús se le pone una capa de terciopelo rojo guarnecida de galones dorados. Lleva también una corona de espinas con rayos de plata y la cruz. Se inicia, así, la secuencia del camino al calvario y las caídas.

Camino del Calvario y Caidas. La columna de la procesión se organiza de manera que al frente de la imagen marchen todos los personajes que han tomado parte en el juicio, van con ellos los ladrones. Frente a la imagen marcha el sacerdote del pueblo y tras ella la comunidad $^{21}$. La procesión en esta ocasión está acompañada por un hombre con un pequeño clarín que hace sonar el instrumento cuando la procesión debe continuar. Cada una de las tres caídas se representa simbólicamente con tres paradas: la primera en la iglesia de San José, la segunda en la de San Diego y la tercera en la de Santa María. Al llegar a cada una de las iglesias, la procesión se detiene y el sacerdote sube a un púlpito movible que se pone junto a la entrada principal de la iglesia o, en el caso de Santa María, a la entrada del atrio. Desde allí dirige un sermón a los feligreses ${ }^{22}$. Cuando la procesión está a punto de avanzar desde San José a San Diego, en un antiguo y alto árbol que se encuentra a pocos metros de la capilla en el camino de la procesión, tiene lugar el ahorcamiento de Judas, quien de pronto aparece suspendido de una de sus ramas. Una vez que ha concluido la caída en San Diego, a la imagen de Jesús en andas se le suman otras dos a sus costados: una de la Verónica y otra de la Virgen de los Dolores. Se trata de andas más pequeñas. En los cuatro extremos de las andas de cada figura se levantan largos «ramilletes» de flores ${ }^{23}$.

Antes de que continúe la procesión, entre San Diego y Santa María, se hace espacio en la calle para la representación de una escena sobre el judío errante amonestado por su

madre ${ }^{24}$. La procesión avanza con las figuras hasta llegar a la calle frente a Santa María. La cantidad de gente que se ha reunido hasta este momento ha crecido de manera significativa. Frente a la iglesia se encuentran tres cruces sobre un puente que antiguamente cruzaba un arroyo que hoy ha sido entubado. Sobre las cruces de los costados son colgados los dos ladrones. La cruz central de Cristo permanecé vacía. Un gran espacio frente a la puerta del atrio sobre la calle es delimitado por los soldados romanos. En este lugar aparecen dos soldados romanos a caballo. Ambos se desplazan de un lado a otro del largo pasillo, mientras uno de ellos comunica al pueblo reunido la sentencia que se le dictado a Cristo. Con esto termina la representación de la «Judea» y la procesión. El sacerdote invita a la comunidad a participar en los «Oficios» del Viernes Santo ${ }^{25}$. Al término de los «Oficios» se procede a desmontar el altar efímero levantado frente al «luto». Se retiran las imágenes de la Dolorosa, San Juan, los dos ladrones, los candeleros.

Descendimiento de la Cruz. Una vez que se despeja el espacio de los altares, los apóstoles vestidos sólo con el alba, proceden a bajar al Cristo de la cruz. Ayudados por paños blancos que impidan el contacto directo de las manos con el cuerpo de la escultura, le quitan los clavos que la sostienen sobre la cruz. Esta figura de Cristo parece ser de piel o tela de modo que los brazos están articulados y cuelgan de los hombros cuando se retiran los clavos que los detienen sobre el madero transversal de la cruz. La escultura, del tamaño de un hombre, es bajada con sumo cuidado y depositada en una urna de paredes de cristal. Un grupo de fieles encabezados por un individuo que lleva lo que llaman la «urnita», pequeña caja de vidrio con monedas dentro, inicia una breve procesión con la urna donde reposa la figura de Cristo que ha sido desclavada. Salen de la iglesia y rodean la manzana. Cantos, oraciones, flores y música acompañan la procesión con la que se cierran las celebraciones del Viernes Santo26.

23

La Dolorosa y la Verónica son imágenes pertenecientes a la iglesia de Santa María. Se supone que ambas encuentran a Jesús en el camino al Calvario.

24

En Tonantzintla, el «judío errante» ofende a Jesús pues no curó a su madre. La madre aparece caminando y le dice a su hijo que pudo curarse gracias a Jesús y le dice que por haber blasfemado contra él su castigo es caminar sin parar hasta el fin de los tiempos. «Una antigua leyenda popular, sucesivamente elaborada en obras literarias de diversos

países, se refiere a Ahasvero, zapatero judío, sobre el cual gravita el peso de la maldición de Cristo durante el drama del calvario. Ahasvero tomó parte en el tumulto de la chusma que pidió la liberación de Barrabás en lugar de Jesús; luego lo rechazó brutalmente cuando se apoyó en el muro de su casa al ser conducido al suplicio; en fin, presenció la Crucifixión. Desde entonces el judío errante vaga por el mundo sin detenerse, $y$ así seguirá, según la leyenda, hasta el día del juicio universal»" ("Diccionario carólico", op. cit., pág. 165).

25

La Misa puede decirse en cualquier día del año, excepto el Viernes Santo.

26

El Sábado Santo, para la Misa de la Vigilia de Pascua, del interior del templo se han quitado los doce "ramilletes» y los adornos de la capilla de la izquierda. La misa se inicia alrededor de las once de la noche. Las luces del atrio y del interior de la iglesia se apagan. En la oscuridad, en una gran tina de aluminio se depositan leños de "ocote» a los que el sacerdote prende fuego. De ese fuego toma la llama para prender un enorme cirio de color rojo y de la lama del cirio los fieles prenden sus propias velas. El sacerdote entra al templo seguido de la comunidad. Aproximadamente la mitad de la misa se lleva a cabo dentro de la oscuridad del templo sólo iluminado por las velas de los fieles. Una segunda parte se inicia cuando después del Credo y como inicio del Ofertorio se abre la "gloria». Las cortinas frente al altar mayor se dejan caer lentamente, se prenden todas las luces, se hacen sonar las campanas y los carillones de la iglesia, se prenden cohetes. Mientras las cortinas descienden de la cúpula, caen pétalos de flores y aproximadamente veinte personas con enormes jarrones colmados de azucenas entran al templo y los colocan en todos los altares. La capilla mayor con la imagen de la dedicación de la iglesia: la Inmaculada Concepción de María, resplandece de luz, oro y flores. El resto de la misa se celebra en el regocijo de la resurrección de Cristo. Es la madrugada del Domingo de Pascua. 

de bulto en las procesiones religiosas, en México, uno de los primeros registros de empleo de imágenes en ceremonias no litúrgicas con motivo de la Semana Santa data de 1582 (Fray Agustín Dávila Padilla, O.P., Historia de la fundación y discurso de la provincia de Santiago de México de la Orden de Predicadores, pról. de Agustín Millares Carlo, México, Academia Literaria, 1955, págs. 567-565)
Notas sobre la fiesta y la representación teatral en la Semana Santa de Santa María de Tonantzintla

OCTAVIO RIVERA KRAKOWSKA

\section{CUATRO}

La representación de Tonantzintla, como otras muchas en México, no incluye a un actor que interprete el papel de Jesús, el cual, como hemos visto, es representado por una figura de bulto del Sagrado Corazón de Jesús que forma parte de las imágenes sagradas permanentes del culto en la iglesia de Santa María y que ocupa la parte central del Retablo de la Pasión ${ }^{27}$. El empleo de esta imagen, tradicional desde las primeras representaciones de Semana Santa en Tonantzintla, intenta subrayar el carácter religioso de la representación, el significado solemne de la muerte de Cristo, y hace imposible intentar "ser» Jesús en la representación teatral. Al eliminar, en general, las figuras vivas de miembros de la comunidad para representar figuras sagradas (a excepción de los apóstoles), se evitan también los aspectos truculentos y la devoción popular se orienta hacia la reflexión interior y la concentración en una imagen siempre presente $y$, a su manera, siempre viva en el templo. Se evita, es evidente, llamar la atención, mediante efectos espectaculares de dolor y de sangre.

En este sentido es útil observar que la compasión del público por el sufrimiento de los actores en escena se podría dirigir, en todo caso, hacia los apóstoles quienes cargan por horas las andas con la imagen de Jesús, descalzos y con coronas de espinas y quienes no dicen un solo parlamento. Recordemos además que poder interpretar a uno de los apóstoles implica, de entre todos los papeles, apuntarse en una lista y esperar un turno que puede tardar años en llegar a cumplirse. A diferencia de otros actores que tienen la oportunidad de mantener un personaje hasta por tres años, para quienes interpretan a los apóstoles, la ocasión se presenta una sola y única vez, un solo año. De entre las distintas secuencias de esta representación, aquellas que podrían prestarse a la compasión de los espectadores por el «hecho vivo» serían las del ahorcamiento de Judas y la crucifixión de Dimas y Gestas. Sin embargo, ambos actos se descubren ante el público sólo como imágenes: Judas colgado de la rama de un árbol, los ladrones sobre sus cruces, no hay acciones previas que desarrollen el acto y despierten el morbo del espectador, simplemente aparecen. En la concepción del mundo de la representación no se presenta a la vista, entonces, tampoco la crucifixión de Jesús, cuya cruz frente al templo, entre las de los dos ladrones, destaca por estar vacía, por su color verde, por estar labrada -a diferencia de las otras-, y porque es un objeto de la liturgia que se usa en la misa del Sábado Santo, de manera similar al Cristo que se emplea en la representación.

Otro aspecto sobre el cual conviene hacer algunas observaciones es el que se refiere al espacio escénico. Como antes se ha señalado, las distintas secciones de la representación disponen escenas en los tres barrios de la población. Esta especie de «escenario múltiple» no es privativo de Tonantzintla y se suma a un sistema de raíces medievales empleado en otras poblaciones del país. En el caso que nos ocupa, sin embargo, es conveniente insistir en que la representación teatral parece obedecer a una manera de hacer participe a toda la comunidad en el acto teatral y su sentido religioso. Metafóricamente Tonantzintla, mediante la representación teatral, se transforma en una Jerusalén efímera, en donde cada escena se desarrolla en un sitio específico del pueblo y distinto de los demás: la última cena en el atrio de Santa María, el largo camino por las calles de la ciudad hacia el Huerto de los Olivos; el Huerto en los límites de la población; el Sanherdín y los pretorios frente a San Pedro; la cárcel en San Miguel; la vía dolorosa de nuevo en sus calles; las caídas en San Miguel y San Diego; el monte Calvario en la explanada frente a Santa María. De esta manera, todos los habitantes del pequeño pueblo, y los sitios comunes de su vida cotidiana, quedan incluidos en las solemnidades de la Semana Santa, por las tareas que les corresponde realizar, y porque muchas de ellas se llevan a cabo en las capillas que son el centro espiritual de sus barrios, además de que empiezan y culminan en el corazón espiritual de su ciudad: la iglesia dedicada a Santa María.

Los requisitos para ocupar el cargo de «Presidente» de la «Corporación», sus facultades, las maneras de la organización, la preparación de los participantes, así como la forma y el sentido de la representación son signos, entre otros, de una tradición de representación teatral cuya conformación actual es, efectivamente, por su rigor, el producto de largo tiempo. El «Presidente» y la «Corporación» responden a esta tradición y, al margen de sus derechos, tienen, sobre todo, la responsabilidad de mantener un propósito y ciertas formas que dependen de un aprendizaje obtenido mediante su pertenencia a la comunidad y la observación de sus fórmulas. Creo que no estaría fuera de lugar decir que el «Presidente» de la "Corporación» funge como un «Maestro de Ceremonias» que conoce 
perfectamente los modos de llevar a cabo la representación teatral, que cumple con ellas de la mejor manera posible y que sus «contribuciones» mediante las modificaciones que se introduzcan están comprendidas dentro de las normas de una tradición en donde no hay rupturas, simplemente porque este es un aspecto que no se considera en Tonantzintla.

La representación de la Pasión en Tonantzintla parece responder pues a un esquema fijo, con las variantes propias, cuando se introducen, de una celebración viva que siempre será un proceso y que las admite, en tanto no sugieran modificaciones que alteren su significación y su propósito y que sean, sobre todo, capaces de intensificar la devoción espiritual, el respeto y la solemnidad del acto representado. Las festividades de la Semana Santa en Tonantzintla, incluida la representación teatral, contribuyen al esplendor de la pequeña comunidad -cuyo máximo representante es el templo principal-y confirman su identidad, no obstante su cercanía a las populosas comunidades de San Andrés y San Pedro Cholula y de la ciudad de Puebla, más expuestas a los movimientos de la población flotante y, por lo mismo, a la posibilidad de mayores influjos culturales.

\section{BIBLIOGRAFÍA}

Catálogo de ferias y fiestas. Estado de Puebla, Puebla, Secretaría de Turismo del Estado de Puebla [1998].

Dávila Padilla, Fray Agustín (O.P.), Historia de la fundación y discurso de la provincia de Santiago de México de la Orden de
Predicadores, 3a. ed., pról. de Agustín Millares Carlo, México, Academia Literaria, 1955.

«Diccionario católico» en Sagrada Biblia, Chicago, La Prensa Católica, 1958, págs. 1-314. (La obra tiene varias numeraciones de páginas. El «Diccionario...» aparece al final del libro con numeración independiente de páginas).

Glockner, Julio (comp.), Mirando el paraíso. Textos sobre Tonantzintla. Antologia, Puebla, Secretaría de Cultura del Gobierno del Estado de Puebla, 1995.

Iglesias y Cabrera, Sonia; Salazar Cárdenas, Leticia; Martínez Gómez, Julio César, La Semana Santa en México. Con la muerte en la cruz, México, Consejo Nacional para la Cultura y las Artes, 2002.

Lomelí Vanegas, Leonardo, Breve bistoria de Puebla, México, El Colegio de México Fondo de Cultura Económica, 2001.

Luna Parra, Adriana (coordinación general), Semana Santa en Iztapalapa, México, Departamento del Distrito Federal - Delegación Iztapalapa, Universidad Autónoma Metropolitana-Iztapalapa - El Juglar, 1992.

Rojas, Pedro, Tonantzintla, México, Universidad Nacional Autónoma de México, 1956.

Rubial García, Antonio, Santa Maria Tonantzintla, un pueblo, un templo, México, Universidad Iberoamericana, 1991.

Ruiz Moreno, Luisa, Santa María Tonantzintla. El relato en imagen, México, Consejo Nacional para la Cultura y las Artes, 1993. 
Licenciada en Literatura Dramática y Teatro por la UNAM. Actualmente estudia la licenciatura en Etnohistoria en la Escuela $\mathrm{Na}$ cional de Antropología e Historia (ENAH) y la maestría en Estudios Mesoamericanos. Se ha dedicado a la docencia de la Literatura en nivel medio-superior, impartiendo asimismo talleres para profesores de arte. En la práctica teatral, realiza montajes como actriz desde hace doce años y como productora desde hace cuatro años. Ha presentado diversas ponencias sobre teatro $y$ etnohistoria en México y Brasil.

\title{
EL JUEGO DE LA CONQUISTA DE SAN AGUSTÍN TLACOTEPEC (OAXACA. MÉXICO)
}

\author{
KARINA CASTRO SANTANA
}

\section{RESUMEN}

Desde que llegaron las danzas de conquista a territorios mexicanos, éstas se han constituido en más que una tradición: se trata de un medio de expresión para las comunidades indígenas que aún desean mostrar su cultura y su punto de vista respecto a un hecho que fue trascendental en la historia de México, así como asegurar y preservar una identidad colectiva.

Trataremos de llevar a cabo en este trabajo la descripción y análisis de la celebración de una de estas danzas que se realiza cada 28 de agosto, en la Mixteca Alta del estado de Oaxaca (México), concretamente en la comunidad indígena de San Agustín Tlacotepec. Dicha festividad integra elementos ceremoniales y dancísticos junto a la conmemoración propia de la onomástica del doctor y obispo de Hipona.

\section{THE GAME OF CONQUEST IN SAN AGUSTÍN TLACOTEPEC (OAXACA, MÉXICO)}

\section{ABSTRACT}

Since the conquest dances arrived on Mexican soil they have become much more than a just a tradition. They are a form of expression for indigenous communities who still wish to demonstrate their culture and point of view with regards to a transcendental event in the bistory of Mexico, not to mention ensuring and preserving a collective identity.

This work will provide a description and analysis of one of these dance celebrations which takes place in the indigenous community of San Augustin Tlacotepec every $28^{\text {th }}$ August in Mixteca Alta in the state of Oaxaca (Mexico). This festivity integrates ceremonial and dance elements alongside the saint's day commemoration of the doctor and bishop of Hipona.

Actualmente en México se realizan numerosas fiestas patronales en las que se pueden observar diversos elementos teatrales que contribuyen a la efectividad de estos festejos. Dichas celebraciones se llevan a cabo cada año, principalmente en las provincias del país; debido a que las comunidades adquirieron, durante el virreinato novohispano, el nombre de algún patrono católico, acompañado de su segundo nombre autóctono. Sin embargo, se respeta el calendario católico para solemnizar sus ceremonias. 
En este artículo se presenta la descripción y análisis de una celebración que se practica en la Mixteca Alta del estado de Oaxaca, en el sur de México. En la comunidad indígena de San Agustín Tlacotepec, se lleva a cabo anualmente, el 28 de agosto, una festividad en la que se conmemora el aniversario luctuoso de San Agustín doctor y obispo. Este festejo integra entre sus elementos ceremoniales, de culto al santo, un juego de conquista.

El término «juego» es aplicado sobre todo a las danzas-drama, debido a que estas representaciones tienen como connotación la de romper con la vida cotidiana de la comunidad en la que se lleva a cabo. «Durante las fiestas [...] el tiempo normal se detiene y da paso al tiempo sagrado» explica Lilian Scheffler, quien a su vez recuerda las palabras de Huizinga:

Esta cancelación temporal del mundo cotidiano se presenta ya de plano en la vida infantil; pero también la vemos claramente en los grandes juegos arraigados en el culto de los pueblos primitivos... Esta suspensión temporal de la vida social ordinaria en gracia a un tiempo sagrado de juego, la podemos encontrar también en culturas avanzadas ${ }^{1}$.

El juego de San Agustín Tlacotepec consiste en la ejecución bailada y dialogada de varios pasajes de la conquista de México en 1521. Estos episodios son presentados en orden cronológico a lo largo de dos días en los que se narra desde la llegada de los españoles, hasta la derrota del pueblo azteca. A pesar de que el primer registro de una teatralización de la conquista en México data del año $1566^{2}$, esta representación tiene su origen en el año de 1932, cuando el señor Isidro Sánchez, habitante de Tlacotepec, adquirió el libreto de la danza en las costas del estado vecino de Guerrero.

La organización del juego comienza unos meses antes, cuando los mayordomos de la fiesta eligen al encargado de dirigirlo ${ }^{3}$. La conformación del elenco se lleva a cabo por decisión del director: él debe ir a solicitar a cada uno de los participantes que se incorpore a la danza; tal solicitud se hace en una comida preparada por la familia del «actor-bailarín». La mayoría de los «actores» son jóvenes entre los 15 y 25 años, aunque también participan señores de hasta 41 años, como es el caso del señor Virgilio López Aguilar quien lleva diez años participando en pastorelas y dos o tres en el Juego de la Conquista. Las ocupaciones de cada uno de los integrantes varían, desde es- tudiantes de informática hasta conductores de camiones escolares o cerrajeros. Cuando el equipo de trabajo está integrado, el tiempo de ensayos oscila entre treinta y sesenta días, en los que se reúnen en la casa del director o los mayordomos para asignar personajes y aprender los diálogos.

El primer día de la

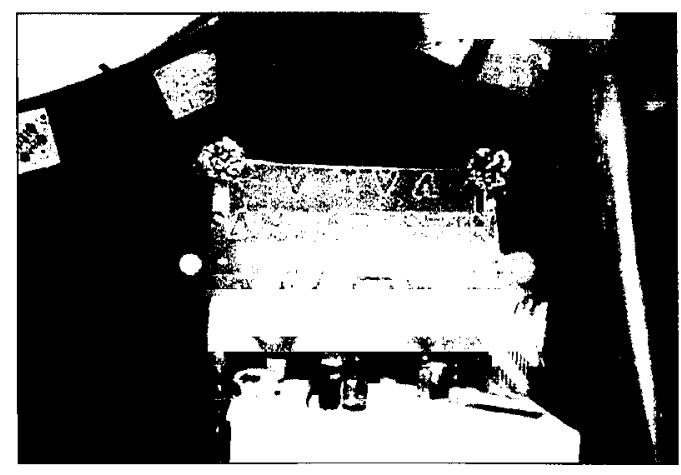

Capilla para los festejos de San Agustín Tlacotepec. representación, los ejecutantes se preparan a partir de las 9 de la mañana; se trasladan al lugar que funge como camerino, ahí comienzan a cambiarse de ropa; en esos momentos el nerviosismo se amalgama con una atmósfera de burlas y risas al verse por primera vez con el vestuario y accesorios que portarán durante el día. Mientras esto sucede, en el escenario en que se llevará a cabo la danza el director supervisa que todo se encuentre en orden y en su lugar. El juego se realiza a un costado del kiosco en el centro del pueblo; en el lugar se observa una explanada en la que se encuentra una plataforma hecha de madera, la cual funge como el único elemento escenográfico de la Danza, ya que como ha explicado Arango,

...en México, el culto sagrado se verifica al aire libre. [...] Las representaciones cristianas permanecen al aire libre, siguen siendo culto indígena en forma cristiana como todo lo que pertenece a él, respecto a procesiones, arcos de flores y enramadas, altares, música y bailes» ${ }^{4}$.

A las 11 horas, da inicio el juego de la conquista con un baile en el que se presenta el bando de los aztecas; luego de 20 minutos aproximadamente hacen su aparición los españoles, quienes llegan en una camioneta que simboliza un barco. A partir de ese momento se narran los episodios más relevantes de la conquista de México-Tencochtitlan. El segundo día culmina con el tormento a Cuauhtémoc y la muerte de Moctezuma, hechos que enmarcan el fin del mundo azteca. Posteriormente se efectúa un baile popular en el que participa la mayoría de los habitantes del pueblo.

Durante estos dos días de juego, en el pueblo de San Agustín se vive un ambiente de fiesta en el que se involucra toda la comunidad. Por un lado, los danzantes, quienes ejecutan las acciones del drama con una devoción extrema, llegando incluso hasta lesionarse de
1

Lilian Scheffler, Juegos tradicionales del Estado de Tlaxcala, México, SEP, 1976, pág. 89.

2

Carlo Bonfiglioli y Jesús Jáuregui, Las danzas de conquista 1 . México contemporáneo, México, FCE, 1996, pág. 22.

3

José Luis González explica sobre los mayordomos: «La otra gran institución popular ligada al desarrollo del culto católico y de las fiestas ha sido el sistema de mayordomías. Esta institución, aunque tiene variantes de un contexto a otro, en todas partes conserva como característica principal el ser una estructura jerarquizada de cargos en orden de asegurar las celebraciones festivas de la comunidad" ("El catolicismo popular y su aporte a la configuración de la cultura mexicana», en Guillermo Bonfil Batalla, comp., Simbiosis de culturas, México, F.C.E., 1993, pág. 552).

4

Manuel Antonio Arango, El teatro religioso en la América Hispana, Barcelona, Puvill Libros S.A., pág. 154

El juego de la conquista de San Agustín Tlacotepec (Oaxaca. México)

KARINA CAS'IRO SAN'JANA 


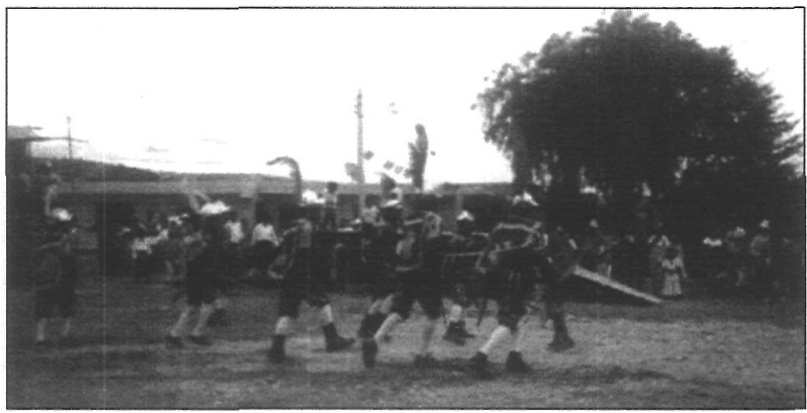

Soldados españoles en el Juego de la Conquista de San Agustín Tlacotepec. gravedad con los machetes que portan para la ejecución. Por otro lado, el resto de los habitantes de la comunidad, que participan como espectadores, quienes paulatinamente a lo largo de la representación abandonan su postura pasiva y terminan por integrarse al juego con comentarios, risas e interviniendo también en los diálogos y los bailables, ya que, como dice Guiraud en relación con la Danza y el juego: «Los espectáculos (y la danza puede ser considerada como tal) son, a la vez juegos y artes: juegos desde el punto de vista de los actores, artes desde el punto de vista de los espectadores» ${ }^{5}$.

Organizar y participar en la fiesta es tomar conciencia y compartir el orgullo de ser tlacotepense. Se participa, quizás como ya ocurría antes de la llegada de los europeos, en una ceremonia que permite expresar el sentido de colectividad y trabajo grupal de una comunidad:

Los ritos nahuas poseen una multitud de elementos teatrales. Es fácil echar a volar la imaginación y tratar de visualizar la escenografía, las danzas, el vestuario, el maquillaje, la utilería, la acción, e imaginar la música y los cantos. En el papel de actores y espectadores participan todos los estratos de la sociedad náhuatl, por lo que se debe también conocer cómo estaba estructurada y qué funciones se ejercían dentro de la mismá.

Actualmente se sigue considerando característico de los pueblos, el trabajo comunitario:

La comunalidad es la gran lección que podemos ofrecer a la sociedad, de ahí que la veamos con gusto reproducirse en la ciudad (Oaxaca), en las colonias, en los barrios pobres, incluso en las grandes ciudades como el D.F. o Los Ángeles, California, en donde encontramos representantes auténticos de esta resistencia heroica, actual y legítima, que dibuja la imagen contemporánea de nuestros pueblos autóctonos oaxaqueños ${ }^{7}$.

En San Agustín Tlacotepec, se observa El juego de la conquista de San Agustín Tlacotepec (Oaxaca. México) KARINA CASTRO SANTANA. que el resto del año cada quien se dedique a ocupaciones diversas, porque la oportunidad de regresar al pueblo natal en la fiesta anual no se puede perder, debido a que también es la ocasión para reencontrarse con amigos y familiares que regularmente no se frecuentan. Como explica José Luis González,

La fiesta anual ha venido siendo, hasta nuestros días, hasta el gran ritual colectivo en el que no sólo las estancias y los ranchos circundantes, sino también los que han emigrado más lejos, se encuentran en el pueblo para participar en una fiesta en la que se reconocen como miembros de una colectividad8.

Las danzas de conquista encuentran también su origen en el carácter ritual con el que los naturales abordaban los hechos trascendentales en una comunidad, es decir, la repercusión idiosincrásica, religiosa y política que regulaba su vida cotidiana.

Cuando los españoles llegaron a tierras americanas buscaron la forma de convertir a los naturales al catolicismo; sin embargo los obstáculos como la diferencia de lenguas, comportamientos y costumbres, obstruyeron la comunicación para iniciar una evangelización efectiva9. Los recursos visuales resultaron ser convenientes para garantizar una explicación de la doctrina católica:

... el primer grupo de misioneros tomó el teatro como elemento didáctico para la enseñanza evangelizadora. Se representaron obras en lengua náhuatl, donde los indios eran actores, cantantes y al mismo tiempo bailaban en los escenarios. Los misioneros dirigían las obras [e] iban induciendo rápidamente al cristianismo ${ }^{10}$.

De esta manera el teatro y las representaciones dancísticas-teatrales resultaron ser los procedimientos más recurridos por los frailes y catequizadores europeos, incluyendo elementos de parafernalia muy vistosos que se utilizaban desde antiguo en los rituales prehispánicos. En la siguiente cita, se observa la descripción detallada de una celebración narrada por fray Bernardino de Sahagún, en la cual se distingue, sobre todo, la parafernalia y el vestuario colorido que utilizaban los antiguos mexicanos en sus ceremonias rituales de sacrificios:

Al séptimo mes llamaban tecuilhuitontli. En este mes hacían fiesta y sacrificio a la diosa de la sal que se llamaba Uixtocíhuatl [...] Los atavíos de esta diosa eran de color amarillo, y una mitra con muchos plumajes 
verdes que salían de ella, como penachos altos [...] tenía en las gargantas de los pies atados cascabeles de oro, o caracolitos blancos, estaban ingeridos en una tira de cuero de tigre; cuando andaba hacían gran sonido [...] llevaba en la mano un bastón rollizo y en lo alto como un palmo o dos ancho, como paleta, adornado con papeles goteado de ulli, tres flores hechas de papel, una en cada tercio; las flores de papel iban llenas de incienso, junto a las flores iban unas plumas de quetzalli cruzadas, o aspadas; cuando bailaba en el areito íbase arrimando al bastón y alzándole al compás del baile"1 .

A propósito de estas manifestaciones prehispánicas que se consideran como un posible teatro, María Sten expone lo siguiente:

...se desprende claramente la existencia de los espectáculos palaciegos y populares, religiosos y profanos, la existencia de lugares especiales para las representaciones, escuelas para los cantores y danzantes, ensayos previos al espectáculo, el uso de máscaras pelucas, pinturas faciales, elementos de escenografía, el diversificado carácter de las danzas y de los cantos, elementos cirqueros y burlescos [...]. Pero este teatro rudimentario que cuenta ya con todos los elementos de la representación tradicional, tiene algo más que lo distingue de modo especial; es un [...] teatro-espejo del hombre y de su mundo; espectáculo religioso que al mismo tiempo es una fuente inapreciable para los estudios antropológicos, que permite descubrir la filosofía de aquella sociedad, sus mitos, el Olimpo de sus dioses, su cosmología, su astrología, su magia y sus ritos ${ }^{12}$.

De esta manera se observa que el sincretismo que se produjo a partir de la conquista de México prevalece hasta nuestros días en las manifestaciones culturales mexicanas; sobre todo las que se generan en comunidades indígenas:

El teatro del Nuevo Mundo tiene un marcado influjo indígena en el estilo, en el colorido y quizá en algunas formas del indio. La decoración de los escenarios en la Nueva España y Perú, corresponde al ritual mágico, indígena. El disfraz, en su mayor parte es indígena. El elemento musical y baile tienen raíces rituales del mundo indio ${ }^{13}$.

En la actualidad, las danzas de conquista obtienen un significado en el que los habitantes de cada comunidad viven el conflicto de diversas maneras. Más que cumplir una función de evangelizar o educar a los pueblos, las danzas se ejecutan con diversas intenciones entre las que destacan la recreación y búsqueda de

la identidad comunitaria:

Hablar de «fiesta» es, antes que nada, referirnos a una comunidad que se reconoce, hacia dentro y hacia fuera, compartiendo un sentido que en primera instancia, ha tenido una referencia

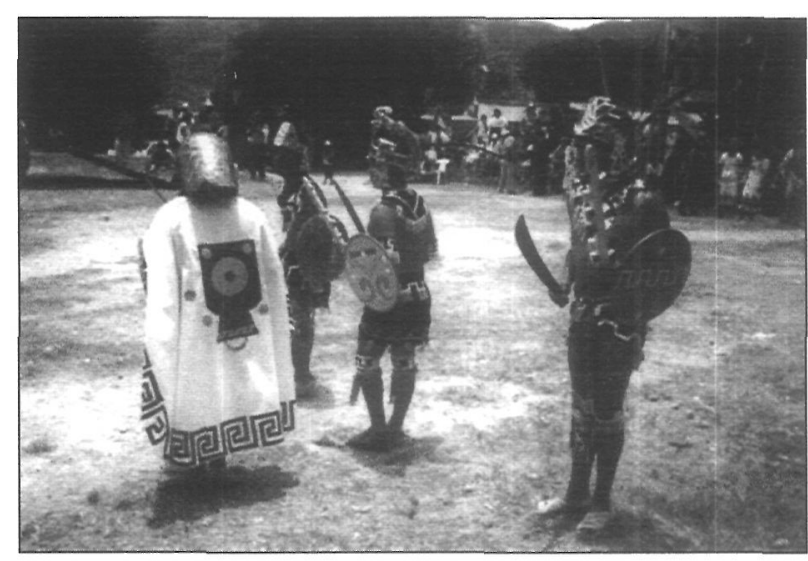

Indígenas en el Juego de la Conquista San Agustín Tlacotepec. religiosa. Navidad, Miércoles de ceniza, Cuaresma, Semana Santa, Corpus Christi, el Día de muertos, la Virgen de Guadalupe, los santuarios, las fiestas patronales de cada pueblo, etc., son otros tantos ejes jerarquizados para la organización del tiempo familiar, comunal, regional y nacional [...]; son la sistematización de la memoria colectiva popular

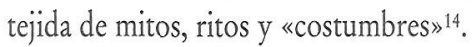

Debido entre otros factores al arraigo de sus tradiciones, el pueblo mexicano sigue ejecutando actualmente gran parte de sus danzas, como una forma de asegurar y recrear su identidad cultural. En el caso específico de San Agustín Tlacotepec, la importancia y repercusión de su danza de conquista radica en un alto grado de identificación con los motivos de lucha de la parte indígena y en que la victoria asegurada por el bando de los españoles no es vivida como algo negativo, sino como lo que justifica o antecede a la aceptación de la liturgia católica, elemento fundamental actual para explicar y entender el sentido de las acciones, festejos y determinaciones que sustentan igualmente la estructura social comunitaria. Un dato curioso, que es digno de mencionarse, es una ocasión en la que uno de los directores asignados llamado Fulgencio Guzmán tuvo la ocurrencia de incluir un estandarte de la Virgen de Guadalupe en el bando de los aztecas con la intención de alentar la fe católica en sus paisanos; sin embargo tal decisión generó diversas opiniones al respecto entre los tlacotepenses, argumentando algunos que era una arbitrariedad utilizar la imagen de la Guadalupana en un contexto en el que cronológicamente es imposible situar, mientras que otros apoyaban la idea, por considerar que era un recurso efectivo para continuar fomentando la religiosidad en la comunidad. De hecho, así ocurre en otras representaciones de la conquista como la que
11

Bernardino de Sahagún, Historia General de las cosas de la Nueva España, México, Porrúa, 1997, pág. 119.

\section{2}

María Sten, Vida y muerte del teatro nahuatl; el Olimpo sin Prometeo, México, SEP, 1974 págs. 30-31.

13

Arango, op. cit., pág. 157.

14

Ibidem, pág. 547. 


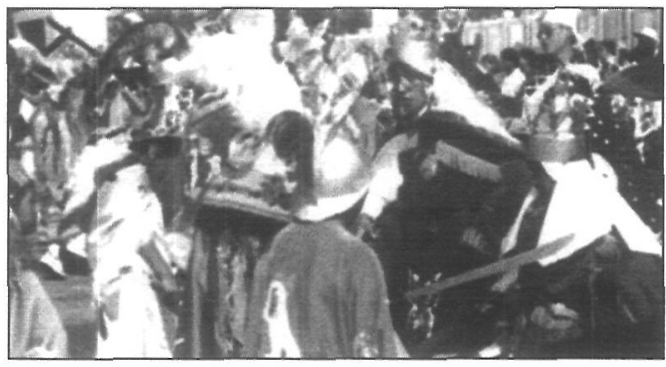

Desarrollo del Juego de la Conquista.

15

Juventino Castro, Diálogo de mestizos, antiensayo sobre 10 mexicano, México, ABISA, 1997, pág. 32

16

Augusto Boal, Técnicas Latinoamericanas de Teatro Popular, México, 1982, pág. 21

17

Cit. en Castro, op. cit., págs. 33 y 34 .

18

Boal, op. cit., pág. 70.

19

Llamado así por su presentación «informal» en cuanto a carencia de un edificio teatral se refiere, así como por el estilo tan peculiar de vincularse los participantes de la manifestación artística con los habitantes que fungen como público.

20

Peter Brook, El espacio vacío, arte y técnicas del teatro, Barcelona, 1972, pág. 85.

El juego de la conquista de San Agustín Tlacotepec (Oaxaca. México)

KARINA CASTRO SANTANA tiene lugar dentro de las celebraciones guadalupanas del 12 de diciembre, la cual ofrecen los habitantes de Amecameca, un pueblo que se ubica en el Estado de México: ellos se trasladan en peregrinación hasta la ciudad de México para ejecutar la danza frente al atrio de la Basílica de Guadalupe, para la cual, como explica Juventino Castro, «hasta la fecha los indígenas se visten con sus plumas y sus atuendos [...] el día que se celebra a la virgen de Guadalupe, o cualquier otra fecha católicopagana, y danzan como lo hacían sus ancestros, en el Tepeyac u otros lugares sagrados desde antiguo» ${ }^{15}$.

Retomando la representación en San Agustín, el hecho de integrar la danza dentro de la fiesta patronal constituye un acto de regulación de las relaciones sociales en la comunidad, es decir, la preparación y participación en la fiesta funcionan de manera semejante a los rituales católicos actualmente practicados (bautizos, confirmaciones, primera comunión, etc.).

Reconociendo en la danza-drama de Tlacotepec una participación colectiva, se puede discurrir que se trata de teatro popular. En primer lugar, cabe aclarar que el término popular se aplica a los espectáculos que se llevan a cabo por el pueblo. A continuación se expone la propuesta de Augusto Boal, quien define el teatro popular, a partir de dos conceptos: población y pueblo.

Población es la totalidad de habitantes de un país o región. Más restringido es el concepto de "pueblo»: incluye sólo a quienes alquilan su fuerza de trabajo. Pueblo es una designación genérica que engloba a obreros, campesinos y a todos los que están temporaria u ocasionalmente asociados a los primeros, como ocurre con los estudiantes y otros sectores en algunos países. Quienes constituyen la población pero no el pueblo -o sea los anti-pueblo- son los propietarios, los latifundistas, la burguesía y sus asociados (ejecutivos, mayordomos) y, en general, todos los que piensan como ellos ${ }^{16}$.

Boal ofrece además una categorización del teatro popular en la que se ubica la representación de San Agustín Tlacotepec, atendiendo sus particularidades:

Teatro del pueblo y para el pueblo: en esta categoría se habla de un trabajo realizado por el pueblo estan- do él mismo como destinatario, es decir, la creación colectiva a partir de las ideas del pueblo, quienes pretenden plantear alguna solución ante una circunstancia para mejorar su comunidad o simplemente para cumplir un ciclo, como es el ejemplo de la danza de conquista de San Agustín Tlacotepec, la cual se celebra cada año en el marco de la fiesta. en honor al santo patrono para fomentar la unión entre los habitantes de esta comunidad. Esta categoría de teatro del pueblo y para el pueblo se divide en tres formas del teatro las cuales tienen diversos objetivos.

a) De propaganda: Con un tinte político, este tipo de teatro funciona como un medio de denuncia ante ciertas situaciones que enfrentan las clases bajas ante las altas.

b) Didáctico: Esta forma de teatro tiene como objetivo proponer una enseñanza para el pueblo, se tratan temas comunes allegados a su vida cotidiana para comprender mejor su entorno.

c) Cultural: El teatro cultural, busca la diversión y el hecho de rescatar tradiciones como danzas, carnavales, etcétera ${ }^{17}$.

De acuerdo a la clasificación empleada por Boal, se identifica que la representación analizada contiene las características del «Teatro del pueblo y para el pueblo» en la categoría "cultural», ya que, como se ha mencionado, el juego tiene por objetivo principal divertir y reunir una vez al año a los habitantes de la comunidad. En palabras de Boal,

Esta es una de las formas teatrales más simples, en las que el pueblo manifiesta libremente sus ideas y emociones. Es, de todas las formas teatrales, la más 'colectiva' la que más inspira y estimula el trabajo conjunto ${ }^{18}$.

Para complementar la definición de teatro popular, cabe citar a Peter Brook, quien habla de un «teatro tosco» ${ }^{19}$, el cual define como: «el teatro que no está en el teatro, el teatro en carretas, en carromatos, en tablados, con el público que permanece en pie, bebiendo, sentado alrededor de las mesas de la taberna, incorporado a la representación, respondiendo a los actores» 20 .

Es evidente que el teatro popular tiene su origen en el planteamiento de una necesidad de una comunidad que mantiene vivas sus tradiciones como una forma de confirmación y divulgación de su identidad.

Considerando que la Danza, como ceremonia de culto a San Agustín, muestra una forma ritual, es pertinente citar los llamados «ritos de paso», de los que se ofrece una breve descripción, para después ubicar la danza 
celebrada en San Agustín Tlacotepec, según lo estipulado en los diferentes ritos expuestos:

A diferencia de los ritos del ciclo de vida, tienen como principal función marcar el paso del tiempo para los grupos sociales y el paso de dichos grupos por el tiempo. [...] En general se trata de grandes celebraciones comunales que indican cambios estacionales 0 anuales y señalan para determinado grupo su tránsito de un estado de normalidad previo relativamente estable y fijo, a otro posterior. [...] Como todas las secuencias ceremoniales que señalan el tránsito de una situación social a otra, constan de tres momentos principales. Se inician con los rituales de separación de la condición social normal que conducen a los ritos liminales y constituyen el estado de marginación o de intemporalidad social, para concluir con los ritos de agregación por los cuales se retorna a la situación normal, pero en un nuevo estado ${ }^{21}$.

La estructura de la fiesta indica el carácter ritual de la danza, planteando fases específicas por las que transcurre la representación como rito. Se habla de tres períodos: uno preliminal, un período liminal y otro postliminal. Todos ellos constituyen los ritos de separación e incorporación, es decir, la vuelta a la armonía o flujo de vida cotidiana en la comunidad antes y después de los días de fiesta.

En términos más descriptivos, el período preliminal consiste en las acciones preparatorias de vestir los trajes apropiados, el traslado al área donde se ejecutará la danza y un intermedio para comer el primer día. El período liminal se caracteriza por el desarrollo del conflicto ritual en el tiempo extracotidiano por medio de la danza teatro. Finalmente, el último período marca una nueva situación de vuelta a la armonía en el tiempo real.

A continuación se clasifican en los periodos descritos anteriormente, la estructura de la Danza y la transición de la comunidad durante la representación:

(DANZA) P. Preliminal: Mundo azteca, unidad armónica. P. Liminal: Confrontación entre españoles y aztecas. P. Posliminal: Fundación de la Nueva España, nueva unidad armónica. (COMUNIDAD) P. Preliminar: Preparativos, Ensayos, Organización, Vestuario. P. Liminal: Representación durante dos días. P. Posliminal: Incorporación a la vida cotidiana y confirmación de su identidad.

Se debe hacer hincapié en que la representación se lleva a cabo sin ninguna condición económica, es decir, todas las personas que participan en el juego lo hacen por una cuestión religiosa, por pagar una manda $u$ ofreci- miento que hayan hecho a cambio de algún «milagro» solicitado a San Agustín. Incluso, algunos habitantes de Tlacotepec deben trasladarse desde diversos lugares para participar en la fiesta, debido a que la mayoría han emigrado a la ciudad de México o a los Estados Unidos de Norteamérica.

En conclusión, la danza de conquista es una tradición en Tlacotepec, dado que la comunidad se niega a romper con un ritual que los mantiene unidos, por lo menos dos o tres meses al año. Más que venerar por medio de su fraternidad y unión a su Santo Patrono San Agustín, la fiesta constituye una oportunidad de recrear una serie de acciones que conforman su identidad. De hecho, como explica Elio Masferrer, ya «en el siglo XIX los historiadores están trabajando los movimientos indígenas desde una perspectiva que incluye un papel de la religión como elemento movilizador $\gg^{22}$.

Cabe destacar que desde que llegaron las danzas de conquista a territorios mexicanos, éstas se han constituido en más que una tradición. Se trata de un medio de expresión para las comunidades indígenas que aún desean mostrar su cultura y su punto de vista respecto a un hecho que fue trascendental en la historia de México, así como asegurar y preservar una identidad colectiva. En cualquier caso, es evidente que la religión católica continúa siendo un factor fundamental en la vida de las comunidades indígenas y mestizas de nuestro país, en el que las prácticas rituales cuentan con una vigencia, gracias al respeto y devoción con que prevalecen las tradiciones mexicanas que se han fortalecido a través de todos estos siglos.

\section{BIBLIOGRAFÍA}

Azor, Ileana, Teatralidades y carnaval. Danzantes y color en Puebla de los Ángeles, México, Gestos, Universidad de las Américas, 2004.

Arango, Manuel Antonio, El teatro religioso colonial en la América hispanoamericana, Barcelona, Puvill Libros, S.A.

Boal, Augusto, Técnicas latinoamericanas de teatro popular, México, Nueva Imagen, 1982.

Bonfiglioli, Carlo, Fariseos y matachines en la Sierra Tarabumara: entre la pasión de Cristo, la transgresión cómico-sexual y las danzas de conquista, México, Instituto Nacional Indigenista, 1993.
21

Bonfiglioli y Jáuregui, op. cit., pág. 22.

22

Elio Masferrer Kan, «Movimientos indios y cuestión religiosa. Encuentros y desencuentros con la antropología en México», en Warman, op. cit., pág. 279. 
- y Jesús Jáuregui, Las danzas de conquista I. México contemporáneo, México, Fondo de Cultura Económica, 1996.

Bonfil Batalla, Guillermo (compilador), Los inmigrantes y su cultura en México, México, Fondo de Cultura Económica, 1993.

- Culturas populares y política cultural, México, Consejo Nacional para la Cultura y las Artes, 1995.

Brook, Peter, El espacio vacio, arte y técnicas del teatro, Barcelona, Península, 1972.

Castro, Juventino, Diálogo de mestizos, México, Abastecedora de Impresos Abisa, 1992.

Díaz del Castillo, Bernal, Historia verdadera de la conquista de la Nueva España, México, Porrúa, 1996.
Fossier, Robert, La Edad Media. vol. 2: El despertar de Europa, Barcelona, Grijalbo, 1988.

Sahagún, Bernardino de, Historia general de las cosas de la Nueva España, México, Porrúa, 1997.

López Austin, Alfredo, El pasado indígena, México, F.C.E., 1996.

Scheffler, Lilian, Juegos tradicionales del estado de Tlaxcala, México, SEP, 1976.

Toríz, Martha, La fiesta prebispánica: un espectáculo teatral, México, INBA, 1993.

Warman, Arturo y Arturo Argueta (coordinadores), Movimientos indigenas contemporáneos en México, México, CIIH (Centro de Investigaciones Interdisciplinarias en Humanidades), Universidad Nacional Autónoma de México, 1993. 


\title{
APROXIMACIONES A LOS TECUANES, DANZA-DRAMA DE ORIGEN NÁHUATL DEL ESTADO DE GUERRERO
}

\author{
ALEJANDRO ORTIZ BULLÉ-GOYRI
}

\section{RESUMEN}

La danza de Tecuanes, de Tigres o de Tlacololeros es una de las expresiones escénicas con mayores elementos mesoamericanos que conocemos y que se mantiene viva. Posee peculiaridades sorprendentes, como su sentido teatral, el humor y el sentido festivo con el que se desarrolla la trama, bastante sencilla, por cierto: es la representación de los esfuerzos de unos cazadores por conseguir atrapar a un tigre. Así también cabe mencionar los elementos mágico-religiosos vinculados con ritos de fertilidad ancestrales que se manifiestan en la danza de Tecuanes.

¿Está vinculada esta danza con la tradición de evangelización, como las otras danzas-drama y representaciones de Guerrero que Maclovio Ariza analiza? Existe además un texto que Fernando Horcasitas debía haber utilizado en el capítulo de su libro El teatro nábuatl II «Farsas de los pueblos» y que quedó inconcluso.

En este trabajo trataremos de describir y reconocer sus elementos más importantes, para permitir más adelante estudios más amplios y clarificadores de esta expresión escénica vinculada en algunos casos con las fiestas de carnaval.

\section{APPROXIMATIONS TO LOS TECUANES: NAHUATL ORIGIN DANCE-DRAMA IN THE STATE OF GUERRERO}

\section{ABSTRACT}

The Tecuanes, Tigres or Tlacololeros dance is one of the scenic expressions with the greatest number of Mesoamerican elements known to us and that remains active. It has surprising peculiarities such as its theatricality, bumour and festive sensibility which develop the fairly simple plot: a representation of hunters' efforts to catch a tiger. The magical-religious element linked to ancestral fertility rights should also be mentioned which is seen in the Tecuanes dance.

Is this dance linked to the evangelist tradition as the other dance-dramas and representations in Guerrero analysed by Maclovio Ariza? Furthermore, there is a text that Fernando Horcasitas must have used in the chapter 'Farsas de los pueblos' in his book El teatro náhuatl II which remained incomplete.

This work will describe and recognise the most important elements so as to allow later, wider studies which clarify this scenic representation linked in some cases with carnival celebrations. y Teatro por la Universidad Nacional Autónoma de México y Doctor en Estudios Ibéricos e IberoAmericanos por la Universidad de Perpignan (Francia). Dramaturgo, director e investigador teatral, ha impartido cursos sobre historia del teatro, literatura hispanoamericana e historia del arte en universidades de México, España y Francia. Actualmente es profesor titular en el Departamento de Humanidades de Ia Universidad Autónoma Metropolitana. Entre sus publicaciones destacan Teatro y vanguardia en el México posrevolucionario (UAM, 2005), las coediciones de El teatro franciscano en la Nueva España (UNAM, 2000) y Teatro y Poder (Universidad de Perpignan, 2002) y su participación en la edición de Fernando Horcasitas, El teatro nátuatl v. /l (UNAM, 2004), así como numerosos artículos en revistas y publicaciones especializadas en teatro tanto americanas como europeas. 


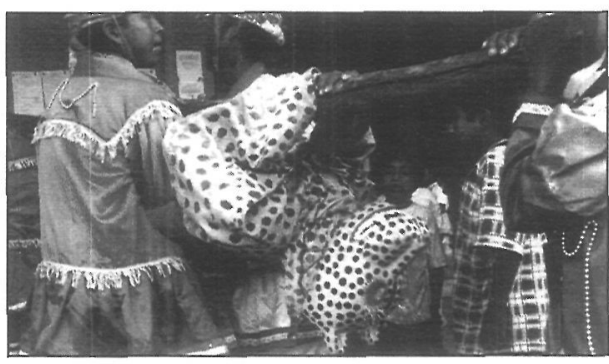

Caza del tigre en Oaxaca. Detalle foto de Darina Robles.

El tigre anda y bulle en las sierras, y entre las peñas y riscos, y también en el agua, y dicen es príncipe y señor de los otros animales; y es avisado y recatado y regálase como el gato, y no siente trabajo ninguno, y tiene asco de beber cosas sucias y hediondas, y tiénese en mucho; es bajo y corpulento y tiene la cola larga, las manos son gruesas,

las manos son gruesas y anchas y tiene el pescuezo grueso; tiene la cabeza grande, las orejas son pequeñas, el hocico grueso y carnoso y corto, y de color prieto, y la nariz tiene grasienta, y tiene la cara ancha

y los ojos relucientes como brasa.

Fray Bernardino de Sahagún, «De las propiedades de los animales", Historia general de las cosas de Nueva España.

1

Fernando Horcasitas (1924.

1980) fue un importante investigador, antropólogo y filólogo, que dedicó sus investigaciones a la recopilación de textos escritos en lengua náhuatl y al estudio de esta lengua y sus hablantes. Uno parte de esas labores se orientó a reflexionar sobre las manifestaciones escénicas y teatrales en náhuatl, especialmente las del llamado teatro de evangelizador del siglo XVI y del teatro tradicional indígena del siglo XX. Parte de ese segundo volumen que proyectaba publicar ha sido editado por María Sten y Germán Viveros en Fernando Horcasitas, Teatro náhuatl II, México, UNAM, 2004.

2

Fernando Horcasitas, "La danza de Tecuanes», Estudios de Cultura Náhuatl, 1980, vol. 14, págs. 238-286.

Aproximaciones a Los Tecuanes, Danza-Drama de origen Náhuat del Estado de Guerrero

ALEJANDRO ORTIZ BULLÉ-GOYRI

\section{NOTA PREVIA}

La danza de Tigres, de Tecuanes, de Tlacololeros, o cualquiera de sus variantes, es una de las expresiones escénicas con mayores elementos mesoamericanos que conocemos y que se mantiene viva. Posee peculiaridades sorprendentes, como su sentido teatral, el humor y el sentido festivo con el que se desarrolla la trama: bastante sencilla en apariencia, se trata de la representación de los esfuerzos de unos cazadores por conseguir atrapar a un tigre. Asimismo cabe mencionar los elementos mágico-religiosos vinculados con ritos de fertilidad ancestrales que se manifiestan en la danza de Tecuanes en forma de un enfrentamiento a golpes «real» entre los intérpretes.

Existe un texto que Fernando Horcasitas ${ }^{1}$ pensaba incluir en el capítulo titulado «Farsas de los pueblos» de su libro El teatro nábuatl v. II. El capítulo referido quedó inconcluso y la versión de Horcasitas del texto de la Danza de Tecuanes permanece en archivos esperando salir a la luz. Sí se encuentra publicado, en cambio, un texto de la danza que editó y publicó acompañando a su ensayo «La Danza de Tecuanes» publicado en Estudios de Cultura Nábuatl2.

En este trabajo haremos principalmente aproximaciones a aspectos que nos parece relevante tomar en consideración para un estudio más amplio y profundo de esta manifestación escénica de origen nahua y de peculiaridades poco exploradas, no sólo dentro del universo de las fiestas y danzas populares mexicanas, sino de manera más específica en el campo de los estudios del teatro en México. Dos son las que consideramos que vale la pena resaltar: su herencia ritual precortesiana y, sobre todo, su carácter festivo, ajeno al espíritu solemne o atemorizante que encontramos en la mayor parte de los casos de dramas y danzas-drama de herencia medieval que, desde el siglo XVI, se representan dentro de los ciclos religiosos cristianos año con año, desde Adviento hasta Pentecostés.

Nuestro objetivo será el de describir y reconocer los elementos más importantes de estas manifestaciones escénicas, para permitir más adelante estudios más amplios y clarificadores de esta expresión escénica vinculada en algunos casos con las fiestas de carnaval. Hay una cuestión sobre estas danzas que quedará sin resolver: si su origen es mesoamericano ¿cómo es que no fueron reconfiguradas por los misioneros en su obra evangelizadora, convirtiéndolas en expresiones danzarias o teatrales de carácter piadoso, o al menos con algunas referencias cristianas edificantes? En cualquier forma, es claro que danzas en donde participan o aparecen ejecutantes personificando a tigres, pueden encontrarse en distintas regiones de México y Centroamérica, y muy probablemente sus orígenes daten de tiempos remotos. En este breve acercamiento nos centraremos las se ejecutan en las regiones que mantienen elementos propios de las culturas nahuas en el Estado de Guerrero al sur de México.

\section{ALGUNOS ESTUUDIOS A PROPÓSITO DE LA DANZA DE TIGRES O TECUA- NES}

No puede decirse en modo alguno que los trabajos en forma de artículos o ensayos, sobre Tecuanes sean exiguos. Hoy podemos encontrar referencias bibliográficas de estudios o acercamientos a la danza que datan de 1910, como el de Elfego Adán sobre las 
danzas de Coatetelco publicado en Anales del Museo Nacional de Arqueología, Historia y Etnologia ${ }^{3}$. Pero sí puede afirmarse que la mayoría se acercan a ésta desde la perspectiva del análisis antropológico o sociológico, presentando aspectos sociales y culturales alrededor de la danza. Otros trabajos en cambio se orientan a testimoniar y a comentar los aspectos musicales y danzarios que aparecen en ella, con el fin de sistematizar su estudio en esos menesteres.

El estudio que más datos y reflexiones aporta sobre esta manifestación escénica lo hace Fernando Horcasitas en 1980 y aparece publicado en la revista Estudios de Cultura Nábuatl ${ }^{4}$. Se trata de un texto amplio; un estudio monográfico que podría haberse publicado de manera independiente de la revista que lo acoge y que revisa, reflexiona y aporta multitud de datos y elementos para ubicar la danza. El estudio de Horcasitas va acompañado de una trascripción de una versión paleografiada, procedente del Estado de Morelos, cuyo manuscrito fue adquirido hacia los años 30-40 por el etnólogo y folklorista norteamericano Donald Cordry.

Hay un trabajo reciente (2003) de Rosalba Díaz Vázquez, titulado El ritual de la lluvia en la tierra de los hombres tigre. Cambio sociocultural en una comunidad nábuatl (Acatlán, Guerrero, 1998-1999)5, que resulta un estudio antropológico muy útil para conocer los aspectos étnicos, sociales y culturales de las comunidades en donde se realiza la danza.

Pero no encontramos estudios específicos en cuanto a los aspectos teatrales y espectaculares de la danza de Tecuanes, o tigres, lo cual nos hace ver la necesidad de orientar un proyecto de investigación hacia el fururo en donde, al analizar la danza, se equipare su presencia mesoamericana con la de la Danza del Guegüence de Nicaragua o se realice una comparación con el Cautivo en Rabinal, o Rabinal Achí de Guatemala, sobre todo en lo que se refiere a los intrincados vínculos entre fiesta ritual, representación dramática y danza ceremonial.

Por lo pronto, al final de estas aproximaciones ofrecemos una bibliografía específica sobre esta danza, que parte de la utilizada por Fernando Horcasitas para realizar sus investigaciones sobre esta expresión escénica, y que aparece tanto en su estudio de 1980 como en la amplia bibliografía expuesta en su fichero personal y que aparece publicada en el volumen II de su Teatro Nábuatl (2004), la cual recomendamos como guía fundamental para estudios sobre danzas y fiestas populares en México ${ }^{6}$. En este libro aparece también un texto titulado «Notas para una lectura sobre danzas mexicanas» donde, de manera sintética, hace observaciones sobre las características y el texto de esta danza de tecuanes a la que él llama «de Coatetelco».

\section{CONSIDERACIONES GENERALES}

La Danza de Tecuanes se escenifica de manera tradicional en las poblaciones de Zitlala, y Acatlán, en la región de la Montaña, en el Estado de Guerrero, hacia el 3 de mayo, día de la Santa Cruz, pero podemos encontrar variantes que se representan en otras regiones del Estado, así como en Oaxaca, Puebla, Chiapas y probablemente en Centroamérica, en distintas fiestas patronales y religiosas, como es el caso de las fiestas de Carnaval, en Juxtlahuaca (Oaxaca).

El vocablo Tecuan significa literalmente «que come gente» ${ }^{\text {. Es decir que el tigre, por }}$ su fiereza y por situarse en Mesoamérica como el animal más poderoso en la cadena alimenticia, adquiere una supremacía tal que incluso es superior al humano, al cual bien puede devorar. Esa, creo, es la causa por la que la danza no se titula en náhuatl como danza de tigres, que sería en todo caso de Ocelotl; es decir, «del tigre» ${ }^{8}$. En todo caso, el término ocelotl, debe referir de manera genérica a todos los felinos y en el caso particular del Tekwan o Tecuan, se trataría de una suerte de jaguar que por su fiereza (y por la consiguiente imposibilidad de su domesticación) adquiere el nombre o el mote de «come gente».

Hay un aspecto interesante que cabe resaltar en relación con las manchas que lleva el tigre (o los tigres) de la danza: remiten no sólo a sus rasgos felinos sino al tigre mítico que se lanzó al fuego después de que Nanahuatzin y Tecuciztécatl se arrojaran asimismo a las llamas en Teotihuacán para crear el nuevo sol y darle movimiento al universo'. Las manchas que lleva son los restos del tizne o cenizas del fuego primordial al que se arrojó también el animal para convertirse así, en el plano mítico, en el símbolo de una fuerza cósmica relacionada con las fuerzas oscuras y nocturnas. No olvidemos tampoco que muchos felinos, especialmente los que habitan las selvas del territorio mexicano poseen, precisamente, hábitos nocturnos, como el de la cacería y el apareamiento.
3

Elfego Adán, "Las danzas de Coatetelco", Anales del Museo Nacional de Arqueología, Historia y Etnología, 1910, núm. 2, pág. 177.

4 Horcasitas, «La danza de Tecuanes», op. cit., págs. 238-286.

5

Rosalia Díaz Vázquez, El rituol de la lluvia en la tierra de los hombres tigre. Cambio sociocultural en una comunidad náhuatl (Acatlón, Guerrero, 1998. 1999), México, CNCA (Culturas populares e indígenas), 2003.

6

Fernando Horcasitas, "Notas para una lectura sobre danzas mexicanas» en El teatro náhuatl, v. II, op. cit., págs. 369-380.

\section{7}

Horcasitas da esa definición de tecuan, siguiendo la idea de que el verbo comer es cua y el prefijo te, refiere a gente. En su libro Náhuatl práctico y ejercicios para el principiante, México, UNAM-Instituto de Investigaciones Antropológicas, 1998, define la palabra TITECUAH como "Comemos gente»; de manera que el Tecuón o Tekwan, es el animal salvaje que devora a los hombres. Es decir, el tigre americano no domesticado, como el jaguar o el puma.

\section{8}

El término «tigre» suena un tanto ajeno a las culturas indoamericanas, toda vez que los tigres como tales no existían en América, sino una amplia variedad de felinos, tales como pumas, jaguares o gatos monteces. Ninguno con la fiereza o la majestuosidad del llamado tigre de bengala.

9

Véase Miguel León Portilla (ed.), De Teotihuacán a los Aztecas, (fuentes e interpretaciones históricas), México, UNAM (Lecturas Universitarias, 11), 1983. 


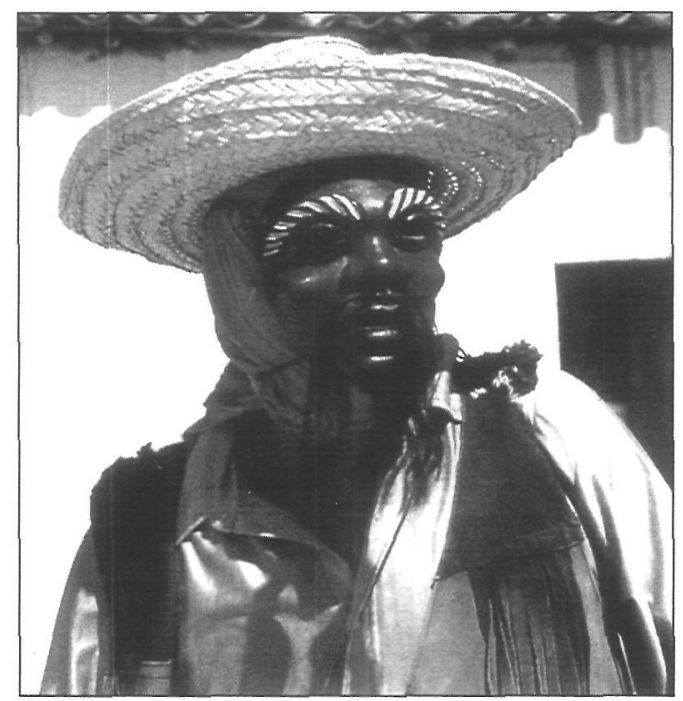

Cazador en una Danza del tigre en Oaxaca. Detalle foto de Darina Robles.

En muchas culturas mesoamericanas como los olmecas, los mayas, la cultura teotihuacana $y$, en general, en el vasto horizonte de las culturas nahuas, el tigre se vinculó con la estirpe de los gobernantes, y se piensa que esa asociación pueda deberse tanto al sentido mítico religioso del felino como a la propia fuerza y majestuosidad inherente al animal, cualquiera que sea la especie ${ }^{10}$. Asimismo, el tigre mesoamericano puede considerarse como una fuerza totémica a la que, en determinados ritos, podría habérsele presentado como una figura patriarcal que había que vencer para que el mundo siguiera su cauce y continuaran los ciclos de vida respectivos.

Mercedes de la Garza nos recuerda en su libro El hombre en el pensamiento religioso nábutl y maya que precisamente «el primer Sol o Sol de Tierra, fue destruido por ocelotes. En él predominó Tezcatlipoca. Los hombres se alimentaron de piñones y fueron comidos por los ocelotes» ${ }^{11}$.

El océlotl se asocia con lo nocturno y con lo femenino, y de ahí probablemente la relación que se establece en la danza con la propiciación de lluvias y en general con la fertilidad ${ }^{12}$. Y de ahí quizás la necesidad de que, en una de las variantes de Tecuanes, corra la sangre para que el ritual propiciatorio cobre sentido. A esa celebración ritual relacionada con la petición de lluvias se le conoce todavía como Atzatziliztli y probablemente haya tenido relación con la fiesta de Atlcabualo entre los mexicas, que era la festividad dedicada a las deidades de la lluvia, como Tláloc.

cas. //NAHUAS. océlotl. Era el segundo signo del ciclo de 260 días o tonalpohualli. En el mito de la creación del Sol se dice que después de que salieron el Sol y la Luna de la hoguera, se arrojaron un águila y un jaguar; éste se "chamuscó» y quedó manchado de negro y blanco. En una de las edades cosmo- gónicas, Quetzalcóatl le da un puntapié a Tezcatlipoca quien se convirtió en jaguar, mismo que es la Constelación de la Osa Mayor. También se dice que los jaguares se comieron a los gigantes que habitaron en la primera edad cosmogónica. Entre los mexicas había una orden de guerreros, llamados océlor»

Llama la atención que, en el calendario festivo del México actual, esta danza sea ejecutada especialmente durante los festejos de la Santa Cruz del tres de mayo, así como en las fiestas de Carnaval y en algunos casos en fiestas de Santos Patronos, así como en honor a la Virgen de Guadalupe el 12 de diciembre.

Entre las variantes más conocidas de las danzas de tigres, están la del modelo, digamos, «clásico», que es la que denomina Horcasitas como "Tecuanes de Coatetelco", en la que se baila y se interpreta un texto dramático que más o menos sigue una historia, pero están también las de los llamados "Tlacololeros», que Horcasitas distingue muy bien como diferentes a los Tecuanes tipo Coatetelco, como él mismo los clasifica, porque tienen un carácter más danzario y chocarrero, como demonios alocados que agitan sus látigos y recorren las calles asustando a los asistentes y espectadores.

Estas son las características que describe Rosalba Díaz Vázquez en su estudio y que Horcasitas no describe con esta precisión:

\section{Los tlacololeros}

Esta danza representa aspectos cotidianos de la siembra del tlacolol ${ }^{13}$. Los doce o catorce participantes se forman en dos hileras, dirigidos por el danzante principal que se distingue por traer un tejón disecado colgado al frente. En general, la indumentaria de tlacololero consiste en un sombrero de palma tejida de ala ancha con un listón alrededor, además de costales que les cubren el frente, la espalda y los brazos. Portan una máscara con rasgos fijos sin pintar y emplean un chirrión o chicote de plástico o de ixtle con el que, al terminar una pieza, se golpean con fuerza unos a otros. Según algunos entrevistados, estos golpes significan la imitación de los truenos y relámpagos que auguran buenas lluvias ${ }^{14}$.

Otro tipo de danzas de tigres es aquella en la que la atención se centra en el aspecto propiciatorio del ritual: el encuentro entre

(Yólotl González Torres, Diccionario de mitología y religión de Mesoamérica, México, Ediciones Larousse, 1991, pág. 99).

13

El término tlacolol o tlacolole, como es denominado en algunas de las regiones del estado de Guerrero, se compone de los siguientes elementos: tlacolotl "vara" y ololi: "en forma de montocitos», se cree que se refiere al tipo de montículos que se hacen al desmontar el terreno de las laderas o en las faldas de un cerro.

14

Díaz Vázquez, op. cit., pág. 87 
tigres que combaten entre ellos en una suerte de sacrificio gladiatorio, donde debe manar y correr la sangre para fertilizar la tierra. Esto es lo que Díaz Vázquez observa al respecto:

\section{La pelea de tigres o tecuanis}

Mención aparte merece la pelea de tigres, un ceremonial que no pertenece a la categoría de las danzas ya que no cuenta con música ni coreografía, es decir, tiene una sucesión de posiciones o pasos, ejecutados a un ritmo musical determinado. Su presentación es exclusiva de esta fiesta y tiene gran importancia en todo el ceremonial.

En primer lugar es una de las fases centrales de la Petición de lluvias, formando parte de la secuencia simbólica del rito propiciatorio: ceremonia de ofrendas y a los vientos para atraer las nubes (ehecame), preparación de la tierra para la siembra y, finalmente, la petición de agua de los tecuanis. Pero ellos no claman e imploran, su exigencia no es verbal, es acción, pelea, dinamismo que se manifiesta en cada golpe de un tecuani sobre otro, también es equilibrio, compatibilidad y control al entregar el tomoxóchitl [flor de color rojo, tal vez del árbol del colorin, que en el Altiplano se conocía como huanacaxtle, con la que por tradición se solicita a una novia como esposa, o al menos en noviazgo ${ }^{15}$, el hombre-tigre entonces pide buena lluvia y buena fertilidad para la tierra y buena semilla para la reproducción, fruto de la unión entre el tecuani y la mujer. Es por eso que su lugar en esta ceremonia es complejo y responde a una lógica rigurosa.

En segundo lugar constituye, por tradición, un rito de paso que los jóvenes desean realizar para mostrar a sus familias y a la comunidad su fortaleza física y su compromiso con la «costumbre» y reforzar las características más sobresalientes de los acatecos, «ser buenos peleadores $»^{16}$.

Extraña que Horcasitas no mencione esta variante en su estudio que en sí mismo es amplio y complejo. La razón estriba, quizás, en que no forma parte de expresiones populares nahuas en donde aparezca un sistema textual específico, es decir, que no hay un texto previo en lengua náhuatl (no hay que olvidar que Horcasitas, antes que etnólogo, era un experto en filología náhuatl y que su interés primordial siempre fue el estudio de la lengua náhuatl). Pero también extraña que en el estudio antropológico de Díaz Vázquez no se haga mención a las Danzas de Tecuanes «tipo Coatetelco», ni a la parte de los diálogos, es decir, a los aspectos propiamente dramáticoliterarios de la danza.

En ambos casos textos, en el de Horcasitas y en el de Díaz Vázquez, se hace referencia a los incuestionables antecedentes prehispánicos o mesoamericanos de la danza de Tecuanes y sus respectivas variantes. Horcasitas, incluso, cita a cronistas como fray Toribio Benavente Motolinía para comentar cómo en el teatro evangelizador del siglo XVI aparecían actores indígenas disfrazados de tigre ${ }^{17}$.

No obstante, da la impresión de que, en ambos casos, parecen haberse quedado cortos en el análisis de los antecedentes mesoamericanos y en los aspectos rituales de las danzas de Tecuanes. Creo, por ello, que vale la pena detenerse en ese aspecto, especialmente en lo tocante a los antecedentes festivos mexicas, de los que tenemos abundantes referencias gracias a la labor etnográfica de fray Bernardino de Sahagún expuesta en su Historia General de las Cosas de la Nueva España.

\section{ALGUNOS ANTECEDENTES Y ASPEC- TOS RITUALES DE LA DANZA}

En la fiesta de Tlacaxipebualixtli, dedicada a Xipe Tótec, el señor de los desollados, la deidad tutelar del manto terrestre, la piel de la madre tierra, Sahagún hace mención a combates entre jóvenes guerreros como parte de la festividad, $y$, aunque en otras festividades se realizan combates entre participantes, en la fiesta de Tlacaxipebualiztli, la segunda en el calendario mexica, algunos de quienes combaten van ataviados como tigres, en una suerte de sacrificio gladiatorio. Menciona Sahagún al respecto:

Poníanse todos sentados sobre unos lechos de heno, o de tízatl o greda; y estando ahí sentados, otros mancebos provocábanlos a pelear, y los otros huían, y alcanzándolos comenzaban a luchar o pelear los unos con otros, y se prendían los unos a los otros (...).

En acabando esta pelea luego comenzaban a acuchillar a los que habían de morir acuchillados sobre la muela.

Peleaban contra ellos cuatro, los dos vestidos como tigres y los otros como águilas; y antes que comenzasen a pelear uno contra uno; y si era valiente el que estaba atado y se defendía bien acometiéndole todos cuatro; en esta pelea iban bailando y haciendo muchos meneos los cuatro ${ }^{18}$.

Podríamos afirmar, pues, que las danzas de tigres, o al menos los combates gladiatorios de tecuanes, poseen un claro antecedente en la vida festiva de las culturas mesoamericanas. Pero, por otra parte, no creo que sea fácil aventurarse a aseverar que la danza y sus diversas variantes, tal como las conocemos, sean precortesianas de origen. Se trata de expresiones

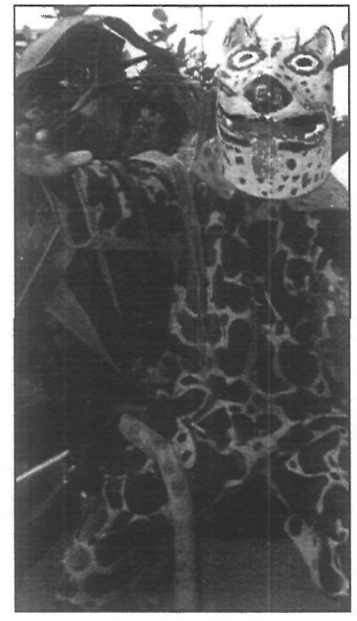

Danzante-tigre de una Danza de Tecuanes de Guerrero.

15

El comentario es nuestro.

16 Op. cit., págs. 89-91.

17

Véase para mayor referencia documental María Sten (coord), Óscar Armando García Gutiérrez y Alejandro Ortiz BulléGoyri (eds.) El teatro franciscano en la Nueva España (Fuentes y ensayos para el estudio del teatro de evangelización del siglo XVI), México, UNAM-CONACULTA/FONCA, 2000.

18

Fray Bernardino de Sahagún, Historia General de las Cosas de la Nueva España, México, Porrúa, 1999, pág. 101. El subrayado es nuestro.
Aproximaciones a Los Tecuanes, Danza-Drama de origen Náhuatl del Estado de Guerrero

ALEJANDRO ORTIZ BULLÉ-GOYRI 


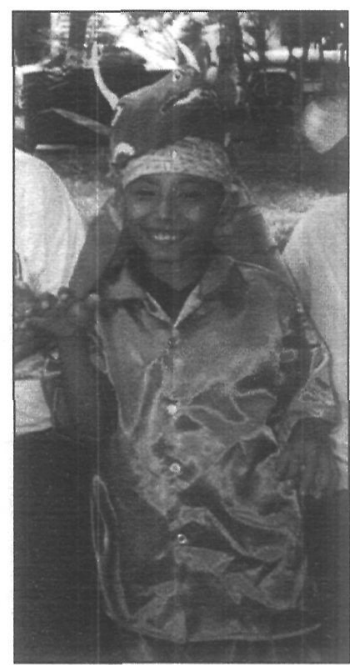

Danzante-venablo de una Danza de Tecuanes de Guerrero.

\begin{abstract}
19
Beatriz Aracil Varón nos hace ver que Carlos Navarrete encontró un documento inquisitorial novohispano interesante sobre la presencia de las danzas de tigres en la Colonia: Carlos Navarrete, «Prohibición de la danza del iigre en Tamulte, Tabasco en 1631 », Tlalocan VI:4 (1971) págs. 374-376.
\end{abstract}

\section{0}

"Que tiene conjura, secreto, ciencia transmitida por tradición») (fray Bernardino de Sahagún, «Vocabulario», en op. cit., pág. 939).

\section{1}

Ibidem., págs. 621-622.

\section{2}

Arturo Jiménez, «En Zitlala, la \|luvia llega convocada por la violencia», La Jornada, secc. Cultura, domingo 8 de mayo, 2005, págs. 3-4. Con el fin de constatar esa presencia de las danzas de tigres en otras comunidades y en otras fechas, acudí en el mes de agosto a la población de Tecpan de Galeana en el Estado de Guerrero. Si bien sólo encontré en dicha fiesta ciertas formas de combates escénicos, como los que suelen darse en la llamada «topa de toro", la presencia del tigre y de las danzas de Tecuanes y sus respectivos encuentros gladiatorios permanecía latente con la presencia en la procesión de una Danza de Mapaches, cercana a la de Tecuanes, que incluye a un

Aproximaciones a Los Tecuanes, Danza-Drama de origen Náhuat del Estado de Guerrero

ALEJANDRO ORTIZ BULLÉ-GOYRI sincréticas que se fueron amalgamando durante los procesos de aculturación en los distintos pueblos mesoamericanos evangelizados por franciscanos, agustinos o dominicos que aprovecharon la rica tradición escénica y festiva de los pueblos indígenas durante la conquista y colonia para cristianizarlos ${ }^{19}$. En cualquier forma, no es de nuestro interés demostrar en estas líneas la autenticidad o pureza prehispánica de la Danza de Tecuanes o sus variantes.

Hay también en la Historia General de las Cosas de la Nueva España de Sahagún una mención por demás interesante sobre una práctica que tenían, entre los mexicas, los cazadores de tigres:

Una gente que eran como asesinos, los cuales se llamaban nonotzaleque ${ }^{20}$, era gente osada y atrevida para matar, traían consigo del pellejo del tigre un pedazo de la frente y otro pedazo del pecho, y el cabo de la cola y las uñas y el corazón, y el colmillo y los hocicos; decían que con esto eran fuertes y osados, y espantables a todos, y todos les temían, y a ninguno habían miedo por razón de tener consigo estas cosas del tigre"21.

Esta observación de Sahagún, si bien no refiere propiamente a un antecedente directo de la Danza de Tecuanes, nos hace ver la relación mágica que se solía establecer con los atributos del tigre a través del acto de enfundarse con partes y piel del tigre recién cazado. La utilización de disfraces y máscaras con formas de tigres en las diversas variantes de tigres podría ser una derivación de ello, como ocurre específicamente en las peleas de hombres tigres en Zitlala el tres de mayo.

\section{CONSIDERACIONES PARTICULARES}

A pesar de los embates de la cultura urbana y de la «norteamericanización», por factores migratorios, de muchas de las poblaciones del Estado de Guerrero, en donde de manera tradicional se celebra esta danza ritual, es claro que ésta aún se mantiene viva y sabemos que muchos migrantes indígenas que ya radican en el norte suelen volver a sus comunidades, como Zitlala o Acatlán, durante las fiestas de la Santa Cruz, con el fin de participar en la fiesta y formar parte de los contingentes de púgiles que se enfrascarán en el duelo gladiatorio de tigres propiciatorio de lluvias y de la fecundidad de las tierras, como se manifiesta en la crónica de la fiesta de 2005 en Zitlala, a cargo de Arturo Jiménez, publicada en el diario La Jornada 22 .

No son pocos los trabajos, estudios, ensayos o artículos donde se hace referencia a esta danza tan emblemática del Estado de Guerrero, debido en particular a sus aspectos propiamente folklóricos que atraen año con año a turistas de distintas latitudes y no sólo de México. El hecho de que sea una danza en la que se plantea un combate escénico con unos vistosos y coloridos trajes y máscaras de tigres la hace de suyo atractiva, pero, en cambio, no abundan los estudios en los que se aborde la danza no sólo desde sus aspectos de costumbre y tradiciones populares sino desde los aspectos rituales y sus correspondientes reminiscencias mesoamericanas.

Dos han sido las ocasiones en que he tenido la oportunidad de presenciar este espectáculo festivo ritual que considero que es la Danza de Tecuanes: una durante las fiestas de carnaval de Juxtlahuaca, Oaxaca, y otra en una suerte de exhibición en Zitlala, Guerrero, como parte de las actividades de una fiesta de teatro comunitario ${ }^{23}$. En ambos casos la danza me pareció fascinante, pero por razones diferentes. La primera destacó por su carácter festivo, su espectacularidad y por la interacción que los danzantes enmascarados de tigres lograban con los espectadores participantes de la fiesta de carnaval; la segunda por la violencia «real» que se desata entre los tigres y el reguero de sangre que salpica a los propios combatientes, a la tierra y a los asistentes a la fiesta ${ }^{24}$.

Ambos aspectos, el carácter festivo y el carácter de ritual propiciatorio, unidos a los elementos mágico-religiosos y simbólicos alrededor de la figura del felino, le dan a Los Tecuanes un sentido mesoamericano que con mucho se diferencia de la mayoría de formas escénicas dramáticas o danzarias relacionadas con la tradición escénica de origen misionero tigre que supuestamente seró cazado (como se plantea en el modelo que Horcasitas llama danzas tipo Coatetelco).

\section{3}

Es claro que lo que presencié se trató de dos de las variantes de danzas de tigres más conocidas: la de Tlacololeros y la otra de Atzatziliztli con su respectivo combate gladiatorio.

24

Esta última situación me tomó tan desprevenido que llegué a pensar y sentir que la riña iba en serio, por el número de combatientes y que podría ser yo también alcanzado por los golpes, lo que no ocurrió, desde luego; aunque quizá hubiera sido un alto honor para mí, pues la tierra de Zitlala, en el Estado de Guerrero, se hubiera regado con mi propia sangre $y$ hubiera ayudado a fertilizar los terrenos agrícolas y a atraer las lluvias generosas y dadoras de la vida en la región. 
y de herencia medieval en México. En este sentido, el tigre americano y su simbología bien podían considerarse como manifestaciones del mal, como ocurría con la célebre tarasca de las procesiones del Corpus Christi en todo el mundo hispánico ${ }^{25}$. No lo podría afirmar de manera categórica, pero me parece una buena hipótesis.

En definitiva, la Danza de Tecuanes ofrece todavía múltiples aspectos de interés al investigador teatral; esperamos por ello poder ofrecer en un futuro un estudio más completo y esclarecedor en torno de esta expresión de la cultura escénica tradicional mexicana.

\section{BIBLIOGRAFÍA CITADA}

Adán, Elfego, «Las danzas de Coatetelco», Anales del Museo Nacional de Arqueologia, Historia y Etnologia, 1910, núm. 2, pág. 177.

Ariza, Maclovio, Teatro de evangelización en Chilapa, Guerrero, Chilpancingo, Universidad Autónoma de Guerrero, 1989.

Barlow, R. H., Ichcateopan (Tekwanis), ms. Archivo Barlow [Universidad de Las Américas], Cholula, 1947 ca.

- In Tekwanis, versión I» Expediente $\mathrm{Na}$ buatl Language in Guerrero, Archivo Barlow [Universidad de Las Américas, Cholula.

-, Tekwanis, Tlamacazapa II, ms. Archivo Barlow [Universidad de Las Américas], Cholula.

Canciones y danzas folklóricas de las Américas, Washington, E.U., Unión Panamericana, [s.d.].

Cinco décadas de investigación sobre música $y$ danza indigena, coord. Julio Herrera, México, INI, 2002.

La danza del tecuán (investigación y edición de FONADAN), México, FONADAN, 1975.

Danzas mexicanas auténticas, México, SEP, Depto. De Enseñanza Agrícola y Normal Rural, 1937.

Díaz Vázquez, Rosalba, El ritual de la lluvia en la tierra de los hombres tigre. Cambio sociocultural en una comunidad nábuatl (Acatlán, Guerrero, 1998-1999), México, CNCA (Culturas populares e indígenas), 2003.

Garza Mercedes, de la, El hombre en el pensamiento religioso nábuatl y maya, México, UNAM, 1978, págs. 20-31.

González Torres, Yólotl, Diccionario de mitología y religión de Mesoamérica, México, Ediciones Larousse, 1991.
Horcasitas, Fernando, «La danza de Tecuanes», Estudios de Cultura Nábuatl, 1980, vol. 14, págs. 238286.

—, «Los Tecuanes de 1907» (stenographic version), Horcasitas $\mathrm{Pa}$ pers, box 15/f.12, Latin Amercan Library, University of Tulane, USA.

— , «Notas para una lectura sobre danzas mexicanas» en El Teatro Nábuatl v. II, México, UNAM, 2004, págs. 369-380.

—, El teatro nábuatl, v. II (Selección y Estudio Crítico de los materiales inéditos de...), México, UNAM, 2004.

- Nábuatl práctico y ejercicios para

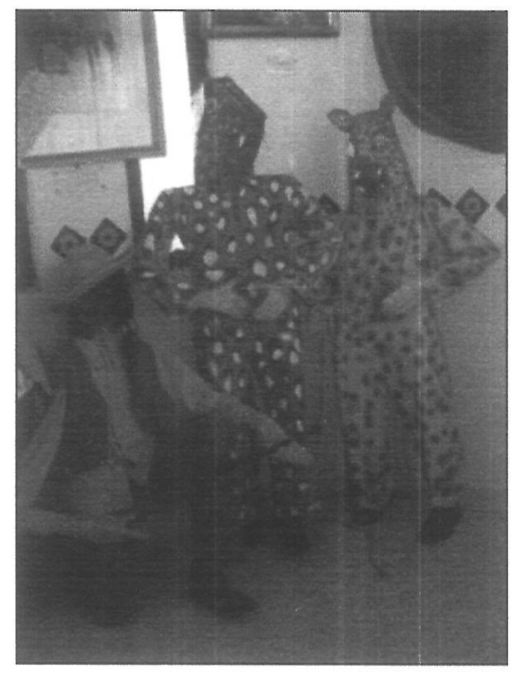

Vestuario de una Danza de Tecuanes. el principiante, México, UNAM-Instituto de Investigaciones Antropológicas, 1998.

Jiménez, Arturo, «En Zitlala, la lluvia llega convocada por la violencia», La Jornada, secc. Cultura, domingo 8 de mayo, 2005, págs. 3-4.

León-Portilla, Miguel (ed.), De Teotibuacán a los Aztecas, (fuentes e interpretaciones bistóricas), México UNAM (Lecturas Universitarias, 11) 1983.

Martí, Samuel, Canto, danza y música precortesiana, México, Fondo de Cultura Económica, 1961.

Moreno de los Arcos, Roberto, «Los cinco soles cosmogónicos», en Estudios de Cultura Nábuatl, 1967, vol. VII, México UNAM, págs. 183-210.

Neff, Francoise, Fiestas de los pueblos indígenas: el rayo y el arcoiris; la fiesta indígena en la montaña de Guerrero y el oeste de Oaxaca, México, INI; Sedesol, 1994.

Navarrete, Carlos, «Prohibición de la danza del tigre en Tamulte, Tabasco en 1631», Tlalocan, 1971, VI:4, págs. 374-376.

Olivera, Mercedes, Catálogo Nacional de Danzas, México, Fondo Nacional para el Desarrollo de la Danza Popular Mexicana, 1974.

Sahagún, fray Bernardino de, Historia General de las Cosas de la Nueva España, México, Porrúa, 1999.

Sten, María (coord.), Óscar Armando García Gutiérrez y Alejandro Ortiz Bullé Goyri (editores), El teatro franciscano en la Nueva España (Fuentes y ensayos para el estudio del teatro de evangelización del siglo XVI), México, UNAM-CONACULTA/ FONCA, 2000.
25

La Tarasca era una suerte de serpiente muy característica del Corpus que personificaba las acechanzas del mal. 


\section{Blanca Cárdenas Fernández}

Doctora en Estudios Hispánicos y Latinoamericanos por la Universidad de Perpignan, Francia. Es profesora-investigadora de tiempo completo en la Escuela de Lengua y Literaturas Hispánicas de la Universidad Michoacana de San Nicołás de Hidalgo de Morelia, Michoacán. Autora de los libros Los cuentos en lengua p'urhépecha. Un punto de de vista sociocrítico e InAuencias e ideología en la obra de Rubén Romero, 'Apocalipsis'. Es además editora y coautora de una docena de libros y autora de varios artículos en publicaciones nacionales e internacionales. Miembro fundador del Seminario interuniversitario de Estudios Sociocríticos y Semióticos. Pertenece al Sistema Nacional de Investigadores de México con nivel II.

\title{
CH'ANANTSKUA (JUEGO DE LA MADUREZ)
}

\author{
BLANCA CÁRDENAS FERNÁNDEZ
}

\section{RESUMEN}

La Ch'anantskua (juego de la madurez), propia del pueblo de Carapan, Michoacán, es una representación ancestral de iniciación de los jóvenes al matrimonio. Esta representación consiste en la demostración que hacen los muchachos (actores), de ambos sexos, ante la población adulta (jueces y público a la vez) de que ya son aptos para el matrimonio; para ello realizan públicamente labores propias de su sexo. Sin embargo, a partir de los años sesenta, esta representación fue incorporando elementos religiosos cristianos, así como profanos referentes al carnaval, de tal suerte que hoy se ha transformado en una amalgama de signos, símbolos e iconos de las culturas p'urhépecha prehispánica, negra y española, que se expresan en una rica polisemia cultural, que pretendemos mostrar en este artículo.

\section{CH'ANANTSKUA (THE GAME OF MATURITY)}

\begin{abstract}
Ch'anantskua (the game of maturity), from the village of Carapan in Michoacan is an ancestral representation of young people's journey into marriage. This representation demonstrates to the adult population (judges and public alike) that the youths (actors) from both sexes are ready for marriage. So as to do this, they publicly carry out work considered inherent to their gender. However, from the sixties, this representation began to include Christian religious elements as well as secular referents from carnivals. In this way, it has today been transformed into an amalgam of signs, symbols and icons of the pre-Hispanic p'urbépecha, black and Spanish cultures, expressed via a rich cultural polysemy that this article aims to demonstrate.
\end{abstract}

Agradecimientos a Saira Arias Pablo por el material proporcionado

Ch'anantskua o «juego de la madurez» es una fiesta de la comunidad p'urhépecha de Carapan, ubicada en la Cañada de los Once Pueblos. Se trata de una representación que hacen los jóvenes del rol socio-económico de los adultos: «juegan» a ser "grandes» realizando el trabajo propio de las personas maduras; así, muchachos y muchachas demuestran ante el pueblo que ya son aptos para el matrimonio. Ellos realizan labores del campo (principalmente cortar leña) pero también hacen patente su «hombría» tomando bebidas embriagantes y jugando a pelear entre ellos. Ellas, por su parte, evidencian su saber en 
bordar un mantel o servilleta y en preparar los alimentos: chapatas ${ }^{1}$, curundas ${ }^{2}$ y churipo ${ }^{3}$. «Si las muchachas ya saben hacer chapatas ya pueden casarse, ya están preparadas para el matrimonio ${ }^{4}$.

En la representación teatral de este «juego» existe una interacción entre el actor y el público, entre el joven y el adulto; cuando el primero tiene alguna dificultad para realizar un trabajo, éste interviene para enseñarle la manera de hacerlo, lo que le da a la representación un carácter de «rito de iniciación» del joven a la vida adulta. «En el juego piden ayuda a los adultos cuando algo se les complica» ${ }^{5}$.

La celebración dura cuatro días, y el escenario donde se desarrolla es el área geográfica del pueblo, el cual se encuentra dividido, para cualquier tipo de actividad, en cuatro partes llamadas cuarteles. «Los jóvenes de los cuatro cuarteles hacen los preparativos dos o tres meses antes, poniéndose de acuerdo con su novia o amiga (...) para que prepare una servilleta, que luego (él) lucirá en la fiesta» ${ }^{6}$. Además, como ellos mismos son los «comisionados», adquieren el compromiso de organizarse para repartirse actividades como la contratación de bandas de música, velar por el buen desarrollo de la fiesta, buscar el árbol del cual se harán los trozos de leña, hacer banderitas de papel de china de diferentes colores que repartirán a sus novias y a los espectadores. Estas banderitas tienen en su centro dibujadas (o caladas) las figuras de un hombre y una mujer como significado de este juego. Sin embargo, la bandera más importante que los jóvenes portan en la fiesta es la servilleta bordada por su novia. Este mantel o servilleta lo amarran con listones de muchos colores a un carrizo, el cual sirve de asta. En los últimos cuarenta años esta servilleta tiene bordadas, en punto de cruz, las figuras de una mujer vestida de china poblana, un torero y un toro.

El ritual de la fiesta, según Carlos Marcelo Valentín ${ }^{7}$, comienza con la entrada al pueblo de las bandas de música; delante de ellas van los jóvenes recorriendo los cuatro cuarteles del pueblo. Un día después se organiza una comida tradicional para actores y espectadores, en ella se ofrece churipo y curundas, y se les obsequia una chapata a cada uno de los asistentes.

El tercer día los jóvenes visitan las casas de los cuatro cuarteles. Cuando sale una muchacha con su servilleta y se la da al joven correspondiente, éste baila hasta dos abajeños, ella por su parte le regala una chapata $y$, reciente-

mente, también una botella de vino para que la comparta con los demás jóvenes. En el transcurso del recorrido que se hace por los cuatro barrios se van sumando a él las múchachas que han dado la servilleta, los adultos y espectadores visitantes; todos siguen el camino rumbo al árbol que ha sido derribado y cortado en trozos. Al llegar a él, los jóvenes co-

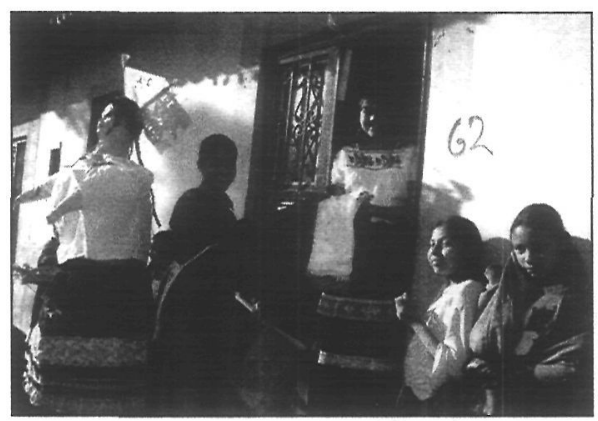

Fiesta de la madurez. Muchacha que ha bordado sus manteles. mienzan a bailar y a repartir brazadas de leña y banderitas de colores a las chicas para que ellas lleven luego la leña al atrio del templo. El cuarto día se hace una procesión con el Señor del Rescate acompañado de otras imágenes religiosas como la Virgen María y San Isidro Labrador. Al finalizar, los jóvenes y demás espectadores despiden a las cuatro bandas de música y las muchachas le regalan una chapata a cada uno de los músicos.

Ch'anantskua se encuentra estrechamente vinculada a la organización de las fiestas prehispánicas, principalmente a tres de ellas: a la de Sicuindiro, que es una representación cósmica del número cuatro en la que se venera a los dioses de las cuatro partes del mundo, a otras festividades ligadas a los rituales de la fertilidad y a la correspondiente a las bodas.

En la Relación de Michoacán se describen varias celebraciones que ponen en evidencia el número cuatro; otras de ellas se refieren al rol de la producción agrícola, que va desde la petición de las lluvias a las cosechas, como ya habíamos comentado. La fiesta religiosa de Sicuindiro es una de ellas y estaba dedicada a los dioses de las cuatro partes del mundo para obtener lluvias abundantes que redundaran en buenas cosechas.

... éstos (los señores principales) representaban las nubes blanca y amarilla, colorada y negra, disfrazándose para representar cada nube de éstas. Habiendo de representar la nube negra, vestíanse de negro y así las otras. Y bailaban estos allí con los otros y otros cuatro sacerdotes que representaban otros dioses que estaban con la dicha Cuerauaperi'.

El escenario de la fiesta simboliza las cuatro partes del universo, cada una de las cuales está representada por un dios, y una nube de color de acuerdo al punto cardinal del que se trate. En esta cultura el cuadrado derivado de la divinidad de la constelación de la Cruz del Sur es una alegoría del espacio cósmico celeste; $\sin$ embargo, este modelo es reproducido
1 Tamales grandes rellenos de frijoles molidos con piloncillo.

2

Otro tipo de tamal que puede estar relleno de carne con chile.

3

Carne de res cocida con col y guisada con chile rojo, se come con las curundas.

4 Comentarista del vídeo Ch'anantskua. El juego de la madurez, realización y guión de Dante Cerano Bautista, Videoteca Iberoamericana I, México, 1999.

5

Ibidem.

6

J. Guadalupe Aguilar Ortiz, Carapan: ir escribiendo, Zamora, editora del Semanario Guía, 1997, pág. 18.

7

Locutor de Radio Cheran y de la ZM de Zamora, en J. Gudalupe Ortiz, op.cit., págs. 18-20

8

Jerónimo de Alcalá, Relación de Michoacán, México, SEP, 1988, pág. 49. 


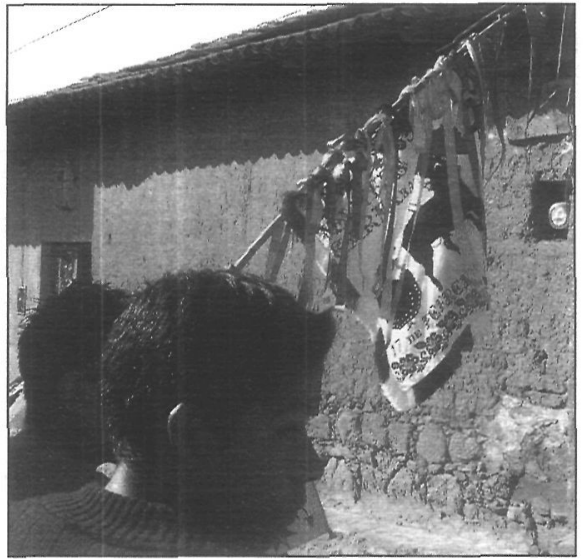

Joven portando el mantel de su novia en la fiesta. también en la tierra y en el inframundo. Tal figura dominante en los tres lugares cósmicos se hace presente aún hoy en día en los rituales religiosos y en la vida social de este pueblo.

En Ch'anantskua queremos señalar algunos aspectos de la subsistencia de la representación del cuadrado: el escenario se divide en cuatro partes, la fiesta tiene una duración de cuatro días (de lunes a jueves), se contratan cuatro bandas de música, los jóvenes se organizan en cuatro grupos, entre otros. Aquí se muestra cómo aún subsiste la visión del cosmos sagrado en las fiestas actuales, puesto que el número cuatro se reproduce a nivel cultural no sólo en el espacio geográfico y en aspectos divinos como templos, deidades y rituales, sino también a nivel social en costumbres y leyes que rigen al pueblo p'urhépecha.

Los ritos de fertilidad los encontramos en la coincidencia en fechas de la representación de la fiesta actual con las de las celebraciones antiguas; por ejemplo en la de Euanscunícuaro, de enáscuni (sembrar):

Ibidem, pág. 32.

11

Mircea Eliade, Tratado de historia de las religiones, México, Era, 2004, págs. 320-321.

\section{2}

Jerónimo de Alcalá, op.cit., pág. 262

13

Ibidem.

14

J. Guadalupe Aguilar Orliz,op. cit., pág. 17.

15

Jerónimo de Alcalá, op.cit., pág. 265.

Ch'anantskua

(Juego de la madurez)

BLANCA CÁRDENAS

FERNÁNDEZ ...era el mes de la siembra, del 9 al 28 de abril. Desfile de doncellas con sus canacuas (coronas de flores) y mancebos con sus tarecuas, (coas para la siembra). Era de cantos, de alegría, de tierra abierta, de bebidas frescas (...) de chapata, pan de bledos, de chía o de amaranto. Todo lo regía la mano de los dioses, pero también el ciclo del maíz, vida y carne del hombre»?

Sin embargo, Ch'anantskua parece haber tomado también algunos elementos, principalmente, de la fiesta celebrada en el mes de charapuzapi ("Charapu, rojo, bermejo. Y sapi, niño adolescente o joven» ${ }^{10}$ ). Era la fiesta de los niños, de los jóvenes, que se celebraba del 16 de septiembre al 5 de octubre. Esto coincide con lo que comenta Mircea Eliade de que la sexualidad en los ritos agrarios es propia de varias culturas, en muchas de las cuales se dan bodas o uniones de jóvenes en los surcos ${ }^{11}$.

En lo que respecta a las bodas antiguas, los elementos de la fiesta actual que se encuentran íntimamente relacionados con el ritual del matrimonio prehispánico son: los cuatro días, la leña, la servilleta y las chapatas, principalmente. En las bodas de los p'urhépecha prehispánicos había intercambio de ajuares:
[Ella] llevaba mantas para su esposo y camisetas y hachas para la leña de los cues, con las esteras que se ponían a las espaldas, y estaba él aparejado y tenía allí su pan de bodas, que eran unos tamales muy grandes llenos de frijoles molidos y jicales y mantas y cántaros y ollas y maíz y ají y semillas de bledos y frijoles en sus trojes; y tenía allí un rimero enaguas y atavíos de mujeres ${ }^{12}$.

La novia (esposa) provee al esposo de camisetas y de las herramientas de trabajo para cortar leña; sin embargo, la leña que él corta no está destinada al hogar, sino a los dioses. También él proporciona a la esposa ropa y utensilios de cocina, pero también la comida suficiente que almacena en sus trojes.

Estos aspectos de la boda prehispánica se encuentran claramente presentes en la fiesta de Ch'anantskua o juego de la madurez, que bien puede identificarse con un ritual de iniciación al matrimonio; por esto se le llama fiesta de los jóvenes o fiesta de las chapatas. Las chapatas o "pan de boda», como se le llama en la Relación de Michoacán, tienen un papel relevante tanto en el ritual antiguo como en el presente, ya que caracteriza a ambos. Cuando Jerónimo de Alcalá menciona el «pan de boda», lo hace para referirse al momento en que llega la novia a la casa del novio para recibir los consejos del sacerdote y efectuar la fiesta: «...y así llegaban a la casa del esposo, donde ya estaba él aparejado y tenía allí su pan de boda, que eran unos tamales muy grandes llenos de frijoles molidos ${ }^{13}$. En la fiesta actual se dice que las chapatas son tamales grandes «hechos de harina, frijol molido, endulzado con piloncillo, envueltas con hojas de matas de maíz (...); se preparan desde tres días antes y se reparten primero entre los cuñados y abuelos» ${ }^{14}$. Repartir las chapatas primero entre los cuñados y abuelos es un hecho que remite también a las bodas prehispánicas, en las que se priorizan los parientes políticos de los novios y a los ancianos.

La leña es otro elemento de relevancia también en ambos tiempos: en el antiguo el novio la lleva a los cues o altares de los dioses en abstinencia sexual; en las bodas prehispánicas, antes de tener relaciones sexuales, el novio

...iba cuatro días por leña (...) para los cues y la mujer barría su casa y un gran trecho del camino por donde entraban a su casa. Y esto era oración que hacían por ser buenos casados y por durar en su casamiento muchos días en significación de lo cual barría el camino (...) y después se juntaban en uno $0^{15}$. 
En este ritual prehispánico aparece el simbolismo sagrado del cuatro: ir por leña cuatro días, barrer la casa y el camino cuatro días en abstinencia sexual para agradar a los dioses y poder ofrecer a éstos su matrimonio. En el Michoacán antiguo la leña es una ofrenda propia de los dioses, como puede comprobarse a lo largo de la Relación de Michoacán, donde encontramos personajes importantes cortando leña para hacer fuego en los cues en honor a sus deidades. En la fiesta actual los jóvenes deben demostrar ante el pueblo que ya saben cortar leña y tumban un árbol para hacer pilas pequeñas de ésta, las cuales reparten entre las muchachas; ellas la cargan y se van bailando hasta el atrio de templo, donde la obsequian al sacerdote. Antes, dice Raymundo Madrigal Baltasar oriundo de Carapan,

...la leña era depositada en la iglesia, por eso se juntaba muchísima entre los cuatro cuarteles. Esta leña era utilizada por el sacerdote durante todo el año (...), la leña tenía un simbolismo muy especial como símbolo de la fuerza de los jóvenes, como muestra de cumplimiento ${ }^{16}$.

En la observación que hace don Raymundo Madrigal encontramos la conjugación de los tiempos pasado y presente, de lo pagano y lo sagrado, en tanto en la actualidad lo sagrado p'urhépecha o pagano ha tomado un simbolismo cristiano: la leña propia de los dioses prehispánicos es ahora traspasada al sacerdote católico, pero como ritual sagrado antiguo toma un cariz profano cuando se transforma en símbolo de la potencia juvenil.

Las servilleta, o pedazo de tela bordado que se utiliza para envolver las tortillas de maíz, es algo indispensable para la mujer indígena, es un objeto de cocina que no debe faltar en el hogar, por esto puede ser asociada con los objetos de cocina que, en el ritual prehispánico, regala el novio a la novia: «jicales y mantas y cántaros y ollas».

Esta fiesta de los jóvenes, tan relacionada con el ritual del matrimonio prehispánico, ha ido cambiando con el tiempo; incluso los objetos anteriores, que aún subsisten, han sufrido transformaciones debidas a la incorporación de elementos de otras culturas que celebran festividades por la misma fecha que Ch'anantskua, como son la Semana Santa y el Carnaval, de tal suerte que el ritual religioso prehispánico toma matices paganos del Carnaval, pero al mismo tiempo se cristianiza con el recuerdo de la crucifixión de Cristo. De esta forma, Ch'anantskua es hoy en día una fiesta híbrida rica en simbolismos e iconos de diferentes culturas.

Los elementos que en los últimos años ha incorporado Ch'anantskua o «juego de la madurez», son los relacionados con el cristianismo y con la cultura africana; de esta última encontramos principalmente aquellos derivados del Carnaval, específicamente de la celebración del «Torito de petate». Como explica Jorge Amós, el toro de petate es «una tradición de origen africano traída (...) en el siglo XVII $\gg^{17}$; las danzas de esta fiesta imitan al 'toro', $y$ «se encuentran generalmente entre los grupos bantú del sur de África» ${ }^{18}$. Creemos que esta adopción por los p'urhépecha se debe a la coincidencia de las fechas de celebración del torito y de Ch'anantskua, independientemente de que ambas tengan un propósito ritual de fertilidad, puesto que «es un 'toro negro' el que se sacrifica entre los bantú de África del Sur para pedir lluvia»19.

Respecto a la influencia católica, la gente de Carapan afirma que la fiesta comienza a cristianizarse cuando el padre Ernesto Buitrón llega al pueblo como párroco. Él incorpora a esta tradición la celebración del Señor del Rescate, que «es un santo muy milagroso, por lo que las personas del pueblo y sus alrededores colocan sobre su imagen diferentes tipos de ofrenda como dinero, entre otras cosas» 20 . El párroco del lugar, José Guadalupe Aguilar Ortiz, explica que «la imagen del señor del rescate se incrementó para que hubiera también un motivo religioso y no fuera únicamente el día de Ch'anantskua o fiesta. Fue como en el año de 1958 con el padre Buitron, con el fin de que no fuera únicamente la fiesta profana o comercial, sino que aparte hubiera también un motivo religioso, la imagen se venera en Tzintzuntzant» se «importa» de este pueblo ${ }^{21}$, pero con esta imagen se incorpora también la Virgen María porque ella «siempre acompaña a todos los santos en las procesiones», como afirma doña Elvira Erape.

Al mismo tiempo que se añaden los elementos cristianos, se da la importación de elementos carnavelescos, de tal forma que el recorrido que en un principio hacían los muchachos por los cuatro cuarteles del pueblo ahora se ha convertido en una procesión que semeja más a un desfile de Carnaval que a un evento religioso; en este desfile-procesión se

\section{6}

Don Raymundo Madrigal Baltasar, oriundo de Carapan.

17

Jorge Amós Martínez, Los «toros de petate». Una tradición de origen africano traída por los esclavos negros en el siglo XVII, tesis, Facultad de Historia, UMS$\mathrm{NH}, 1999$, pág. Vl.

18

Ibidem, pág. 132.

19

Ibidem, pág. 131.

20

Doña Elvira Erape Baltasar, 68 años, oriunda de Carapan.

21

Don José Guadalupe Aguilar Ortiz, párroco de Carapan.

Ch'anantskua (Juego de la madurez) BLANCA CÁRDENAS FERNÁNDEZ 


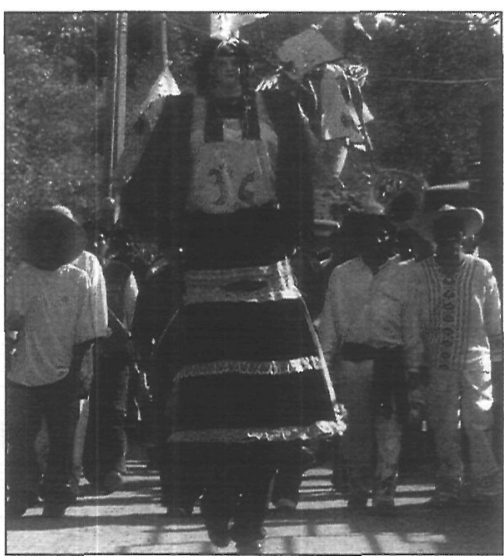

Mojiganga en la procesión de Ch'anantskua. exhiben tanto imágenes religiosas cristianas como toritos y mojigangas, de tal forma que la concepción que se tiene hoy en día acerca de Ch'anantskua es, como dice doña Elvira, «la fiesta de las chapatas, o lo equivalente a un carnaval, es la fiesta de la juventud. En la iglesia, se venera la imagen del Señor del Recate, pintura original de los señores Isidro Alejo y Francisco Pablo de Carapan» ${ }^{22}$. Vale la pena señalar la separación que hace la señora de lo profano y lo sagrado en su discurso al delimitar, por un lado, las fiesta de las chapatas, de carnaval, de la juventud y, por otro, la celebración del templo cristiano como algo aparte y reciente; esto se expone en la denuncia de que la imagen del Cristo fue hecha por la misma gente del pueblo: Isidro Alejo y Francisco Pablo.

Podemos decir entonces que Ch'anantskua Doña Elvira Erape.

23 Mircea Eliade, Lo sagrado y lo profano, Barcelona, Paidós, 1999, págs. 137-138.

24

Ibidem, pág. 138.

25

José Carmelo López, op. cit., pág. 30.

26

Ibidem, pág. 31.
Cb'anantskua (Juego de la madurez)

BLANCA CÁRDENAS FERNÁNDEZ actual es una simbiosis de los rituales de iniciación, de la fertilidad y del matrimonio prehispánicos, pero también esta amalgama de símbolos mezcla directamente al cristianismo y de manera indirecta a la cultura bantú del sur de África.

Decimos que hay signos del ritual de iniciación en esta fiesta-representación porque se inicia a los jóvenes al matrimonio. La aptitud para realizar los trabajos que corresponden al adulto los induce a la sexualidad, pero también los incorpora en el campo laboral, los hace apto para asumir la responsabilidad de estar casados. La iniciación que según Mircea Eliade «equivale a la madurez espiritual $»^{23}$ en Ch'anantskua corresponde a la madurez social y biológica, a la destreza demostrada para unirse al trabajo y a la vida sexual instituida.

El ritual de iniciación también se deja ver en que «los jóvenes candidatos soportan parte de sus pruebas y se les instruye en las tradiciones secretas de la tribu» ${ }^{24}$, lo que podemos observar tanto en la Relación de Michoacán como en Ch'anantskua, sólo que no en las tradiciones 'secretas', sino en los rituales de tradiciones públicas: lo cerrado del ritual se transforma en abierto, más en esta última, ya que agrega no sólo a los familiares de los novios sino a la comunidad entera. Sin embargo, en la fiesta de Carapan se da una desacralización del ritual prehispánico al convertirse sólo en un juego de la madurez, juego que, contrariamente al concepto que representa, posee tal connotación de seriedad, que al final de él surgen varias parejas de casados.
El espacio del ritual cerrado del matrimonio prehispánico se convierte en Ch'anantskua en un lugar abierto: el lugar cerrado que concierne a dos familias (la del novio y la de la novia), que guarda misterios, objetos y ritos sagrados, en el abierto da cabida a todos los ojos del pueblo, hay participación entre actor (joven iniciado) y público (adultos).

En cuanto al ritual de la fertilidad en Ch'anantskua, salta a la vista en primer lugar el mismo matrimonio; sin embargo, vale la pena hacer notar el carácter social que lo caracteriza desde los tiempos prehispánicos, así como la marcada hibridación de que ha sido objeto hasta nuestros días. Ya hemos mencionado anteriormente las fiestas prehispánicas de Sicuindiro, Charapusapi y Enanscuicuaro, entre otras relacionadas con la fertilidad. Tales fiestas se realizaban en la época que va desde la petición de la lluvia hasta las cosechas, aproximadamente de abril a octubre. Las fechas del calendario p'urh' pecha que marcan estas fiestas coinciden con las celebraciones cristianas del 15 de mayo y 24 de junio, día de san Isidro Labrador y de san Juan respectivamente. Ambos santos, aunque tienen las fechas propias de celebración, también van en la procesión de Ch'anantskua. La fiesta religiosa del primero corresponde al mes de Parandatzícuaro, "paranini, llevar algo en la cabeza y tzikua, maíz (...) recién nacido» ${ }^{25}$, por lo que corresponde a la fertilidad. En lo que respecta a la fiesta de san Juan, ésta se ubica en el mes p'urhépecha de Huáscata-Cónscuaro «mes del poder, simbolizado en las flechas, pero también era el mes de la escarda. Uashakani, sentarse, estar en el poder y kúnscani, escardar. Mientras la gente escardaba, los poderosos (...) bebían, celebraban, comían y cantaban a orillas de los ecuaros» ${ }^{26}$.

El calendario p'urhépecha se encuentra organizado en torno al ciclo de la producción del maíz. Este ciclo comienza con la festividad de petición de las lluvias a los dioses de las cuatro partes del mundo; siguen a ésta celebraciones en torno a la preparación de la tierra, la plantación, etapas de crecimiento, y cosecha de este grano; de aquí que podamos decir que se trata de un ritual que va pasando por etapas, y que, en la celebración de éstas, tienen participación prioritaria personas de edades y clases sociales determinadas, de acuerdo al periodo de desarrollo del maíz de que se trate.

En relación a las fechas de la fiesta del toro de petate, podemos observar que coincide también tanto con la celebraciones 
p'urhépecha como con la cristianas, ya que la danza de este toro "se realiza en los días de carnaval (...) o durante el ciclo del nacimiento-muerte de Cristo: Corpus, día de la Candelaria (2 de febrero) San Juan, Domingo de Ramos» ${ }^{27}$. La coincidencia con los antiguos michoacanos se encuentra en las festividades del desarrollo cíclico del maíz, y con las fiestas religiosas de la Iglesia católica, sin duda en la de San Isidro Labrador y la de San Juan.

En cuanto a los toritos, algunas personas de Carapan, como el señor Santos Alejo, pretenden darle a la fiesta un origen propio de la región arguyendo que por eso se borda en la servilleta la imagen del toro; sin embargo, hace más de seis décadas, a decir de la señora María del Refugio Alejo Rodríguez, «las servilletas eran blancas y se llevaban a las bodas, esto entre los años 40 y 42 (...), la imagen del toro bordado comenzó, tal vez, como en los años $50{ }^{28}$, lo que quiere decir que anteriormente servilleta y toro fueron parte de celebraciones distintas y que la unión de ambos se da en el momento en que Ch'anantskua adopta al Torito de petate.

Tal parece que, con la incorporación del Torito de petate a Cb’anantskua, también se agregan las banderillas de colores que portan las muchachas cuando llevan la leña al atrio del templo, puesto que es propio del torito ir «adornado con enormes banderillas de papel de estraza o de china» ${ }^{29}$.

Pero no sólo el torito mencionado se suma a Ch'anantskua, también ésta le imprime un rasgo propio a aquél, puesto que en los pueblos p'urhépecha, en la fiesta del Torito de petate, reparten "gratis muchos tamales (...) comenzando por el señor cura» ${ }^{30}$.

A la fiesta de los toritos que celebran en la ciudad acuden «los rancheros de ambos sexos (...); vienen esos días a pasar el carnaval a la ciudad; y así es de ver a los vecinos de las haciendas o rancherías cercanas ir comiendo públicamente cañas de castilla, naranjas, etc., y seguir a los toritos de petate por todas partes» ${ }^{31}$; esto explica también por qué actualmente, en la celebración de Ch'anantskua, se intercambian chapatas por cañas de azúcar.

Después de exponer las coincidencias de Ch'anantskua con símbolos y elementos de otras culturas, podemos concluir afirmando que tales concurrencias tienen como punto de contacto las fechas de celebración, y que la concordancia cultural que posee nuestra fiesta con las culturas cristiana y africana se basa en que las tres aluden a la fertilidad de la tierra de alguna forma. Sin embargo, no es nada fácil deslindar en Ch'anantskua una cultura de otra, un tiempo de otro tiempo, mucho menos un símbolo de otro símbolo; de aquí que nuestra intención, en este artículo, no sea la de resolver este problema, sino la de mostrar elementos y fechas que contribuyen al abigarramiento cultural de esta fiesta-representación del pueblo de Carapan.

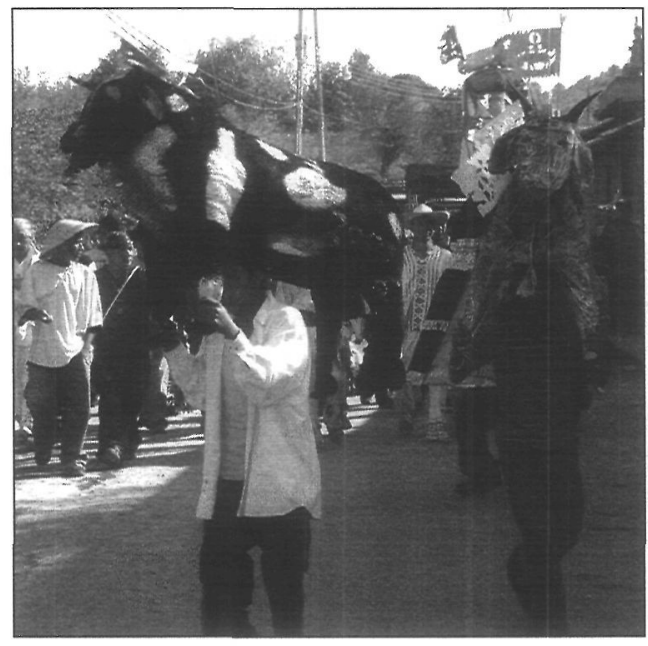

El «torito de petate».

\section{BIBLIOGRAFÍA CITADA}

Alcalá, Jerónimo de, Relación de Michoacán, México, SEP, 1988.

Aguilar Ortiz, José Guadalupe, Carapan: ir escribiendo, Zamora, Editora del Semanario Guía, 1997.

Aguirre Beltrán, Gonzalo, La población negra de México, México, FCE, 1989.

Álvarez de Miranda, Ángel, Ritos y juegos del toro, Taurus, Madrid, 1962.

Amós Martínez, Jorge, Los toros de petate. Una tradición de origen africano traida por los esclavos negros en el siglo XVII, tesis, Facultad de Historia de la UMSNH, 1999.

Ch'anantskua. El juego de la madurez (vídeo), realización y guión de Dante Cerano Bautista, Videoteca Iberoamericana, México, 1999.

Deschamps, Hubert, Las religiones del África negra, EUDEBA, Buenos Aires, 1962.

Eliade, Mircea, Mito y realidad, Barcelona, Labor, 1992.

- Lo sagrado y lo profano, Barcelona, Paidós,1999.

- Tratado de historia de las religiones, México, Era, 2004.

- Historia de las creencias y de las ideas religiosas, Barcelona, Herder, 1999.

López, José Carmelo, El día que murió un imperio, Uruapan, CONACULTA, Gobierno del Estado, Secretaría de Cultura, 2005.

Torres, Mariano de Jesús, «Los toritos de petate», en Juan Hernández Luna y Álvaro Ochoa Serrano, Fiestas y costumbres morelianas del pasado inmediato, UMSNH, El Colegio de Michoacán, 1991.

27

Jorge Amós Martínez Ayala, op. cit., pág. VI.

28

Doña María del Refugio Alejo Rodríguez, vecina de Carapan.

29

Mariano de Jesús Torres, «Los toritos de petate», en Juan Hernández Luna y Álvaro Ochoa Serrano, Fiestas y costumbres morelianas del pasado inmediato, Morelia, UMSNH, El Colegio de Michoacán, 1991, pág. 156.

30

Ibidem, pág. 161.

31

Ibidem, pág. 159. 



\section{PEUISTA AMERECA SIII MOMBPBE}
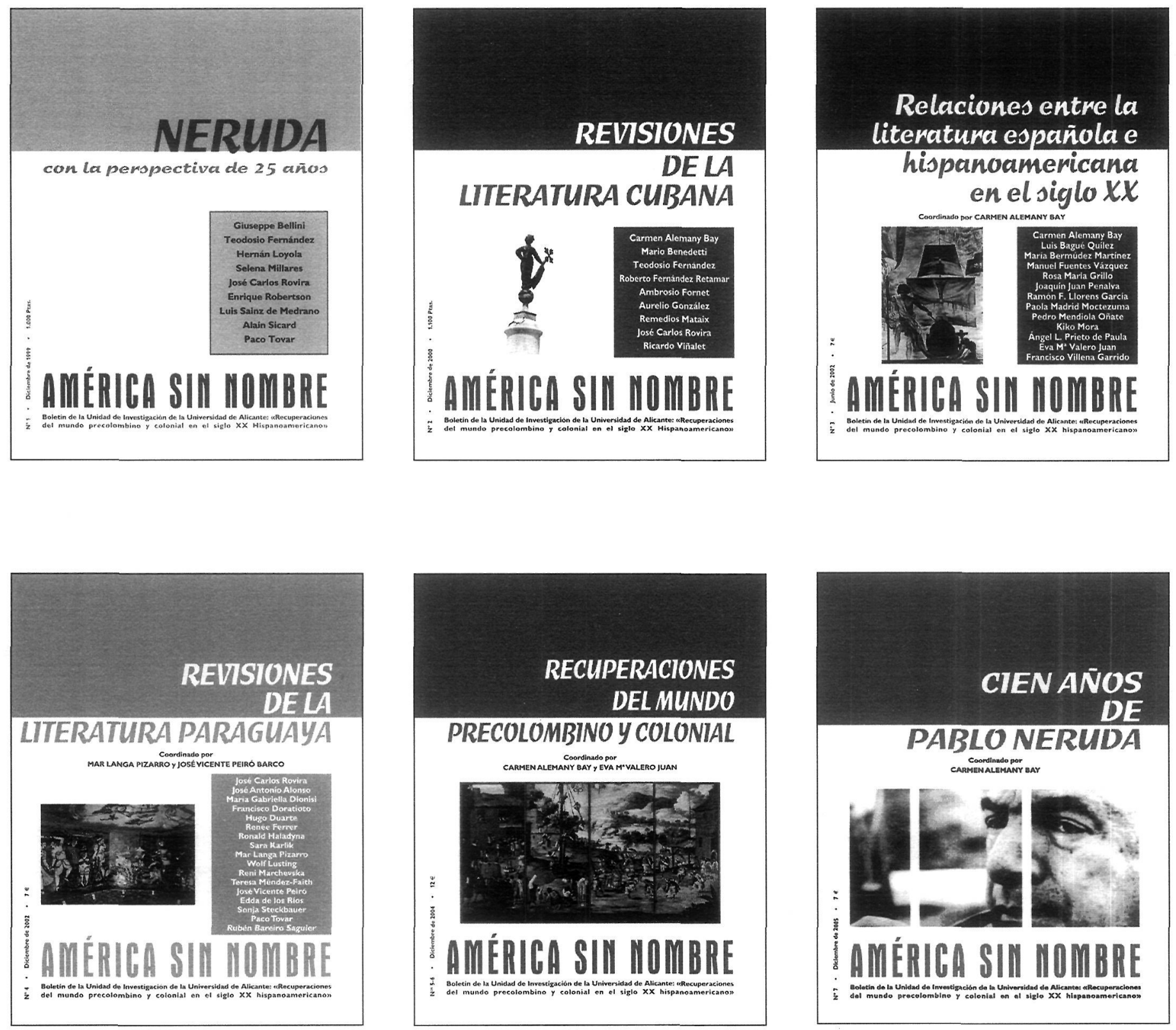


\section{CUADERMOS DE AMÉRECC SIII IOMBPBE}

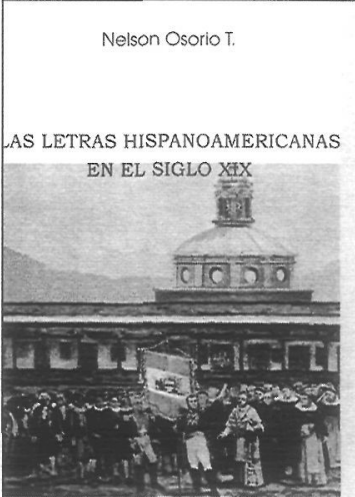

Protaga de Tase Carlos Racera

CUADERINOS DE AMÉRICA SIN NOMBRE
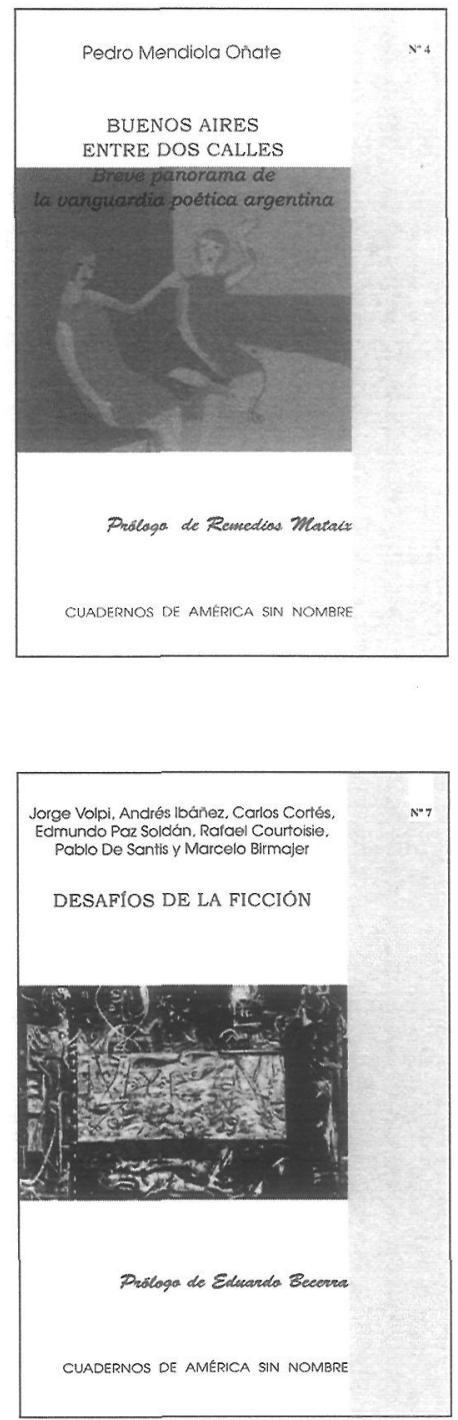
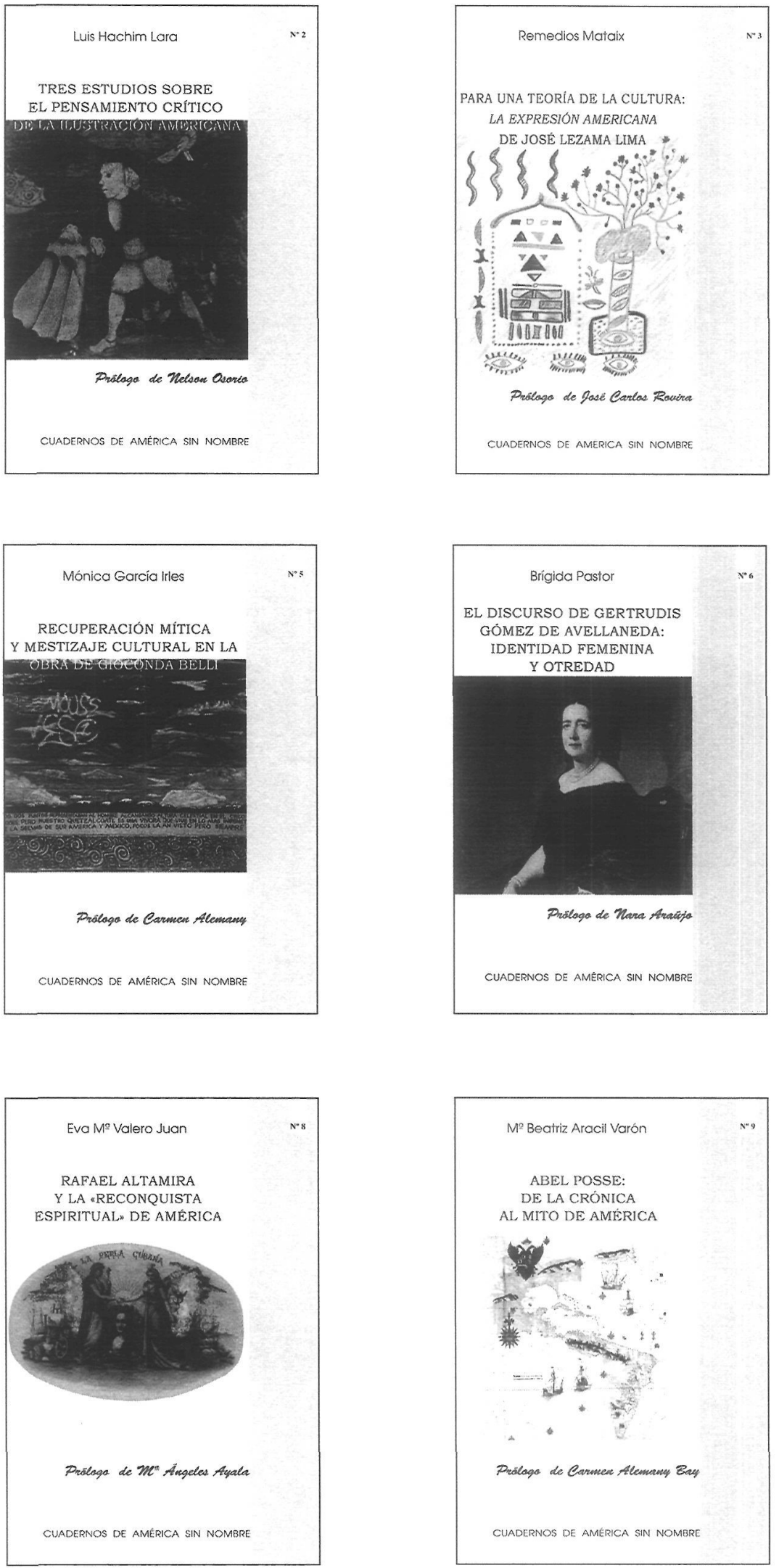

$M^{2}$ Beatriz Aracil Varón

ABEL POSSE:

DE LA CRONICA

AL MITO DE AMÉRICA

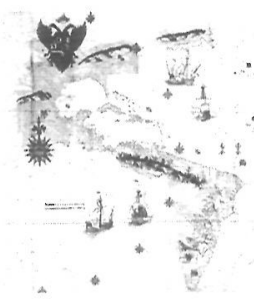

Prologo de Canonen Alemenny Bay 


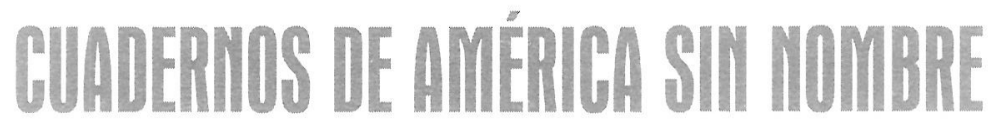
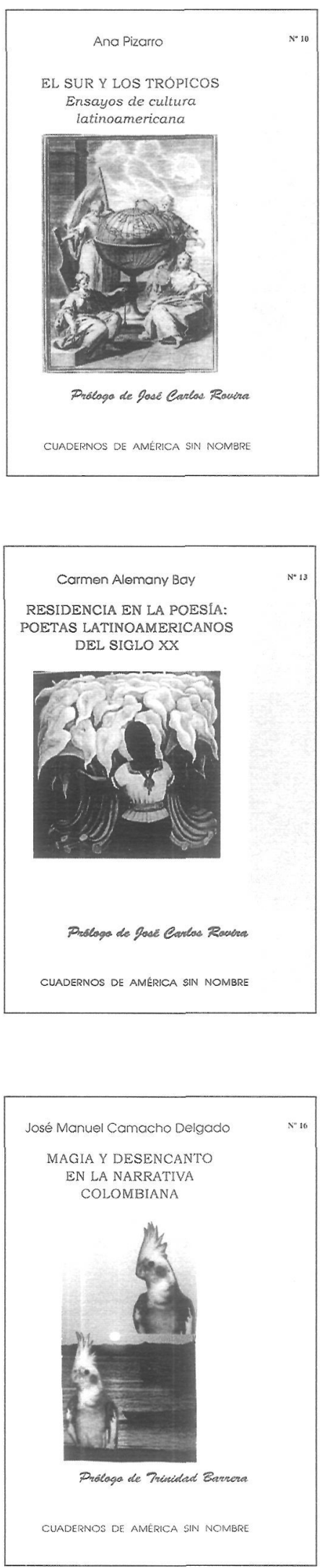
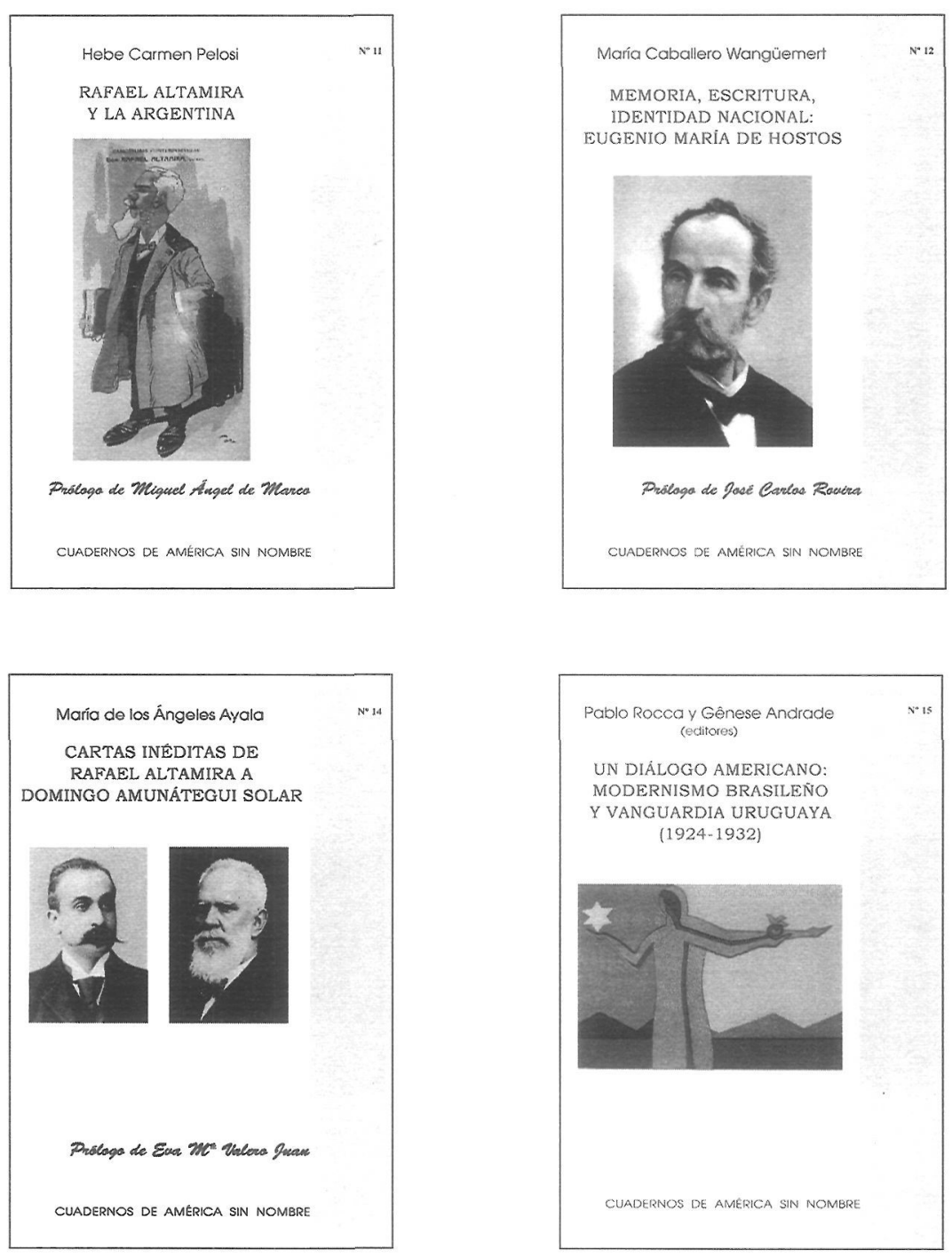


\section{AMÉRICA SII NOMBBEE \\ BOLETÍN DE SUSCRIPCIÓN}

Nombre

D.N.I.

Dirección

Código Postal y población

Teléfono

Derechos de suscripción: tres números (ordinarios o extraordinarios) de América sin nombre que le serán remitidos por correo a la dirección arriba detallada.

Precio: $21 €$

Forma de pago:

Contra reembolso de cada ejemplar. (8€).

- Por talón nominativo, dirigido a Dpto. de Filología Española, Universidad de Alicante. Apartado de Correos 99 - E03080, Alicante (España). 



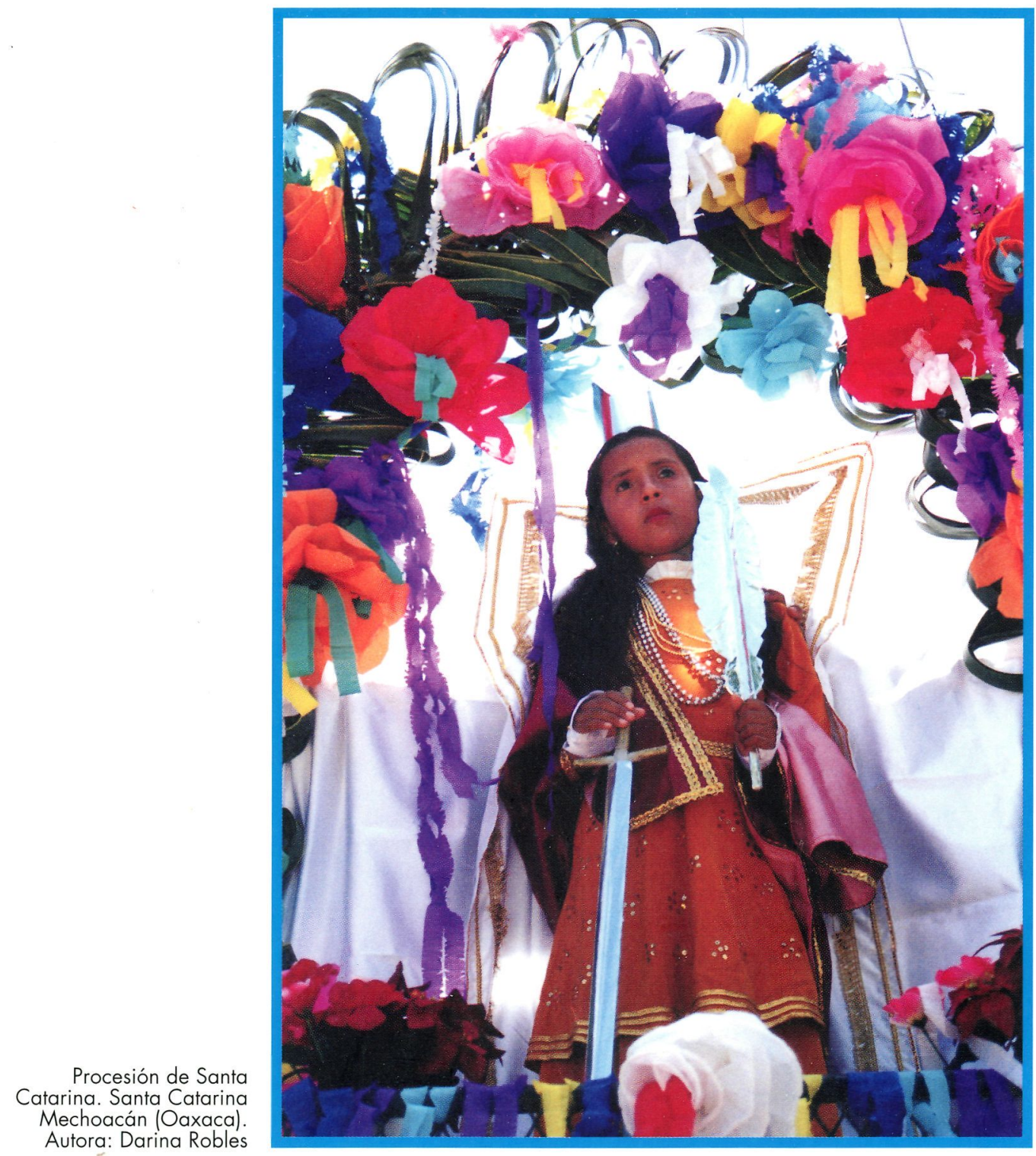

PRÓXIMOS NÚMEROS (2007 y 2008):

— En torno al personaje histórico: las grandes figuras precolombinas y coloniales en la literatura hispanoamericana desde la Independencia a nuestros días.

- La narrativa de Elena Poniatowska.

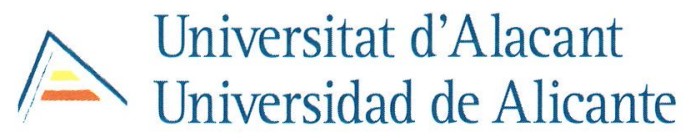

